\title{
Investment Protection under the Energy Charter Treaty
}

\author{
Doctoral (PhD) Dissertation
}

\section{Dildar Frzenda Zuber Zebari}

\section{Supervisors}

\author{
Dr. Krisztina Rúzs Mol \\ Associate professor \\ Department of Labour Law \\ and Social Security \\ Dr. Zoltán Víg \\ Senior lecturer \\ Department of Private \\ International Law
}

UNIVERSITY OF SZEGED

Faculty of Law and Political Sciences

SZEGED 2019 


\section{Contents}

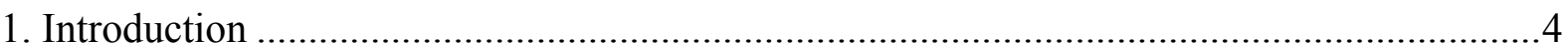

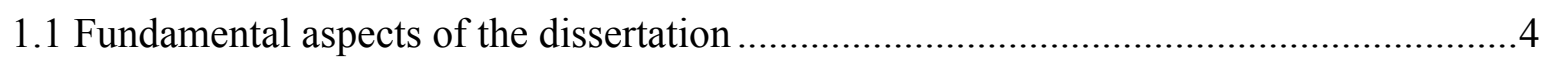

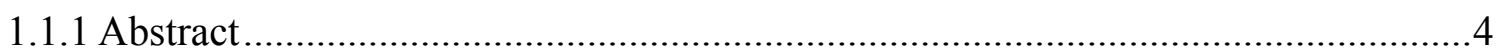

1.1.2 Identification of research tasks .........................................................................

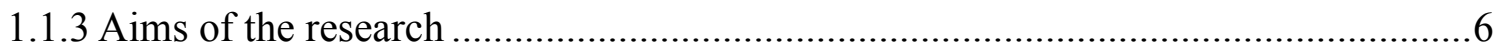

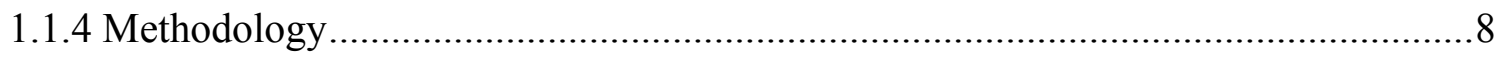

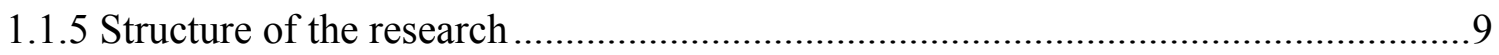

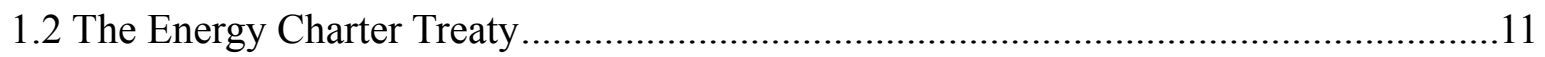

1.2.1 History, evolution and aims ……………………………....................................1

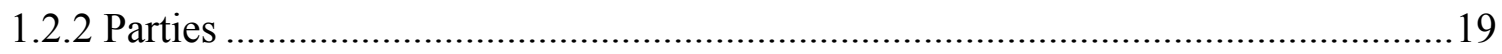

1.2.3 Structure of the Energy Charter Treaty ..............................................................23

2. Dispute settlement mechanism under the Energy Charter Treaty ..........................................24

2.1 Comparing investor-state dispute settlement and commercial arbitration in general.....24

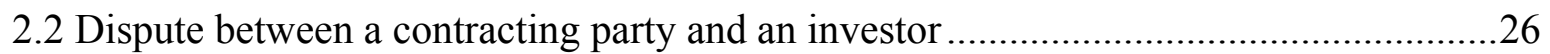

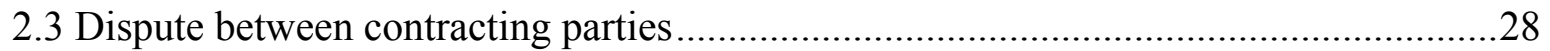

3. The Energy Charter Treaty from the perspective of energy exporting countries ..................31

3.1 Energy Charter Treaty from the perspective of net energy exporting contracting parties.. 32

3.2 Perspectives on the Energy Charter Treaty for non-contracting energy exporters..........34

4. Promotion, protection and treatment of investments and the issues of expropriation and

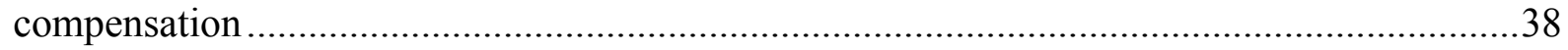

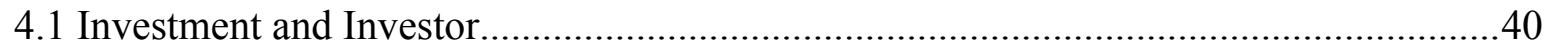

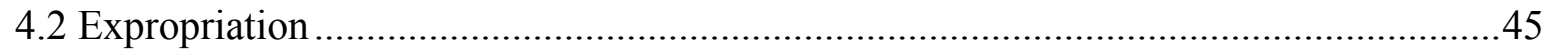

4.2.1 Conditions of Lawful Expropriation under International Law …………………....47

4.2.2 Energy Charter Treaty and Expropriation ……………………………………...52

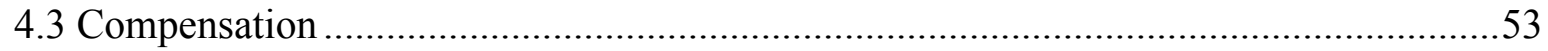

4.3.1 The Standard of Compensation for Expropriation in Investment Treaties ..............56

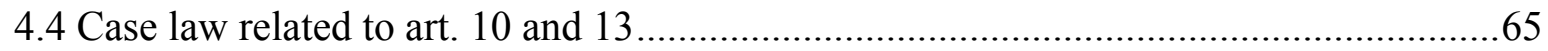

5. Investment protection and related issues in the Energy Charter Treaty.............................117

5.1 The extent of protecting energy investments in the Energy Charter Treaty .................117

5.1.1 Before the Energy Charter Treaty ……………………....................................117

5.1.2 Relevant articles of the Energy Charter Treaty .......................................................118

5.1.3 Investors' complaint under the Energy Charter Treaty............................................129 
5.1.4 Summary of arbitral practice from the perspective of expropriation

5.1.5 Conclusion

5.2 Comparison of compensation under the Energy Charter Treaty and compensation in

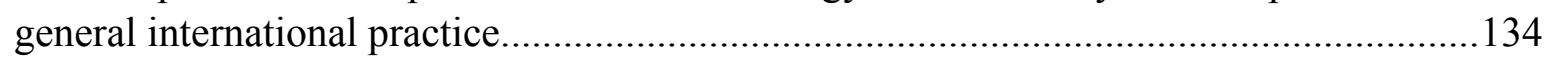

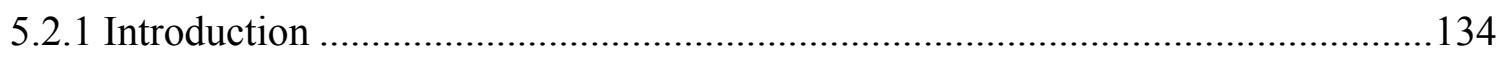

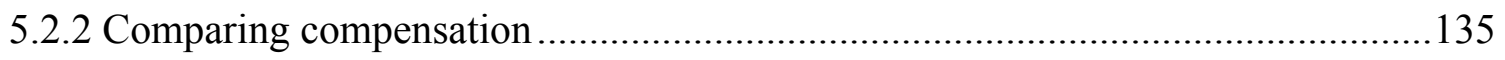

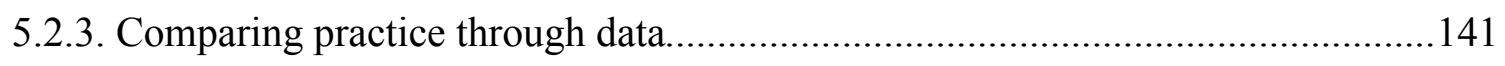

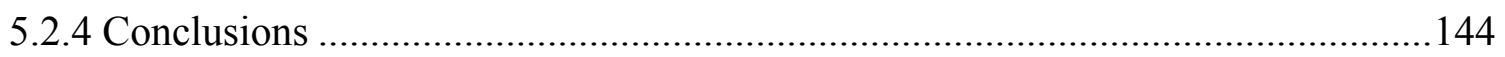

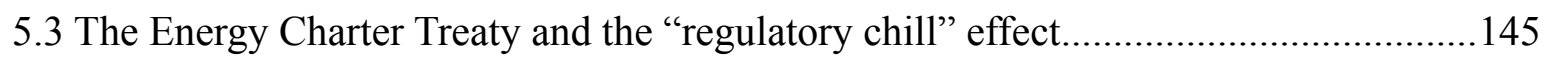

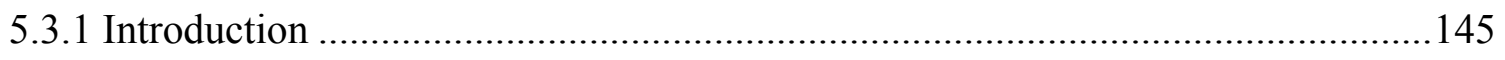

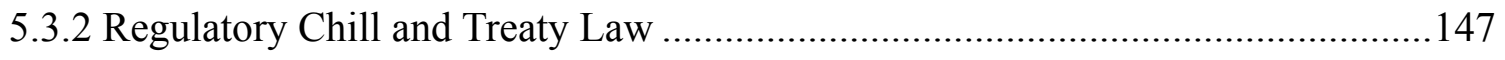

5.3.3 The Right to Regulate - The Interplay Between Public Policy Issues and Investor

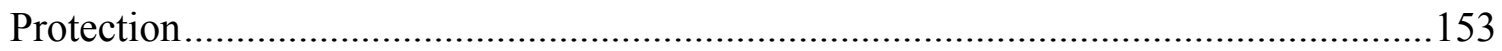

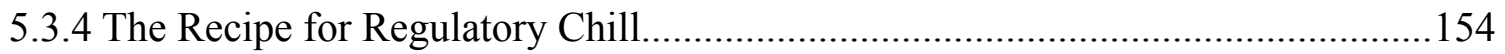

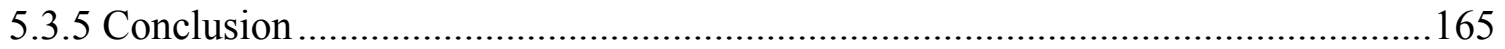

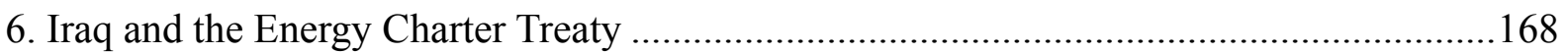

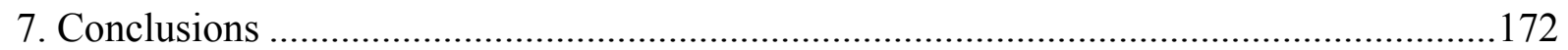

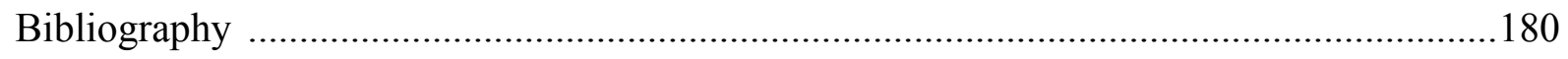

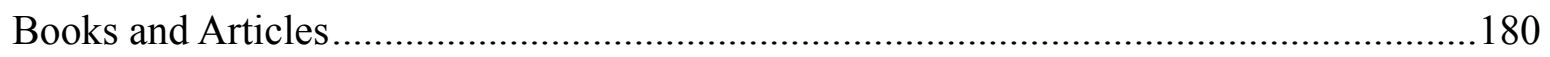

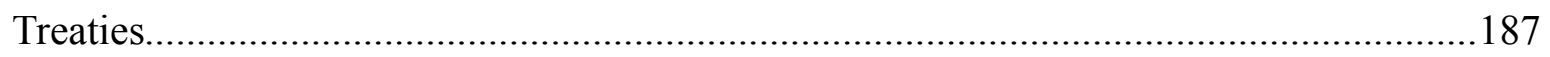

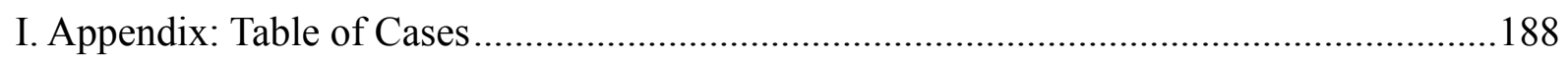




\section{Introduction}

\subsection{Fundamental aspects of the dissertation}

\subsubsection{Abstract}

Investment, particularly cross-border investment, is an unavoidable aspect of many economic sectors. Many countries lack the necessary domestic capital to fund their own business ventures, and thus require outside sources to finance their private sector. However, these same countries (most of which are former Eastern Bloc countries and developing countries) can often be prone to instability, internal divisions and sudden changes of policy by the country's highest authorities. During the 20th century, many examples of countries nationalizing industries or expropriating specific businesses can be observed. Domestic regulations and limits on such activities do not always suffice. Domestic law, after all, can always be changed to suit the whims of the current leadership. Given that cross-border investment typically involves a very substantial amount of capital, foreign investment is a massive risk for investors.

Hence, a need developed to provide a more substantial form of protection, especially through international investment treaties. In my particular case, the investment treaty in question is the Energy Charter Treaty, a highly influential agreement concerning the energy sector.

In general, the goal of the Energy Charter Treaty is to provide a comprehensive and holistic legal framework for the production, transport, and delivery of energy products. It is a synthesis of what bilateral energy treaties were trying to achieve in the first place, such as definitions of what an investor is, safeguard clauses, and the proper method of settling disputes. This synthesis allows it to achieve a uniquely important position when it comes to energy-related investments.

It is also necessary to address the International Energy Charter. This 2015 treaty belongs to the same 'family' as the Energy Charter Treaty. However, this was mainly a political declaration, and not a proper, extensive treaty like the Energy Charter Treaty. It is not considered legally binding, and mostly contains declarations of intent. As such, I felt it unnecessary to 
focus on it, since the provisions with actual, observable and quantifiable real-world effects are the provisions of the Energy Charter Treaty.

The particular focus of this research is thus the Energy Charter Treaty and the related case law. In studying this, I used a wide variety of methods and examined the theoretical and practical (such as case law) aspects of the treaty's investment protection segments thoroughly. One of the chief objectives thus being to uncover the treaty's potential application to Iraq by measuring its comprehensiveness, advantageousness and efficacy.

In a similar vein, I have also considered expanding on the EU aspects of energy investment, but as one of the most important aspects of my work is the applicability of the Energy Charter Treaty to Iraq, and specifically, the Kurdistan Region of Iraq, EU legislation (which could otherwise prove a possible source of inspiration) would dilute this focus too much. Hence, I shall only deal with them in the dissertation in a cursory manner.

\subsubsection{Identification of research tasks}

Based on the aforementioned goal of exploring the comprehensiveness, advantageousness and efficacy of the Energy Charter Treaty, I sought to answer three specific research questions:

- Whether the Energy Charter Treaty guarantees the protection of foreign investments, and if so, to what extent?

- Whether the compensation paid under the Energy Charter Treaty is comparable to international practice?

- Whether the Energy Charter Treaty has a "regulatory chill" effect?

I formulated these based on the following logic. The fundamental issue that I needed to first establish is that what guarantees for foreign investments exist in the Energy Charter Treaty and what is the extent of these. Without answering this question, I could not progress to further examination. After establishing the fundaments, I moved onto specifics, to be precise, compensation, which is likely the chief concern of any foreign investor. Besides the text of the treaty, I also determined that it is necessary to analyze general international practice on compensation in investor-state disputes, in order to determine whether the Energy Charter Treaty's theoretical framework and extant case law shows a 
durable system of compensation or not. Finally, the specter of the so-called "regulatory chill" needed to be addressed. In the past ten years or so, investment-related international agreements have been increasingly accused of causing this supposed effect, and so I determined that this too should be discussed as the final research question of the thesis.

However, there was also need for establishing a more general, all-encompassing foundation for these research question. Thus, I identified the necessity of examining the Energy Charter Treaty's history, evolution, aims and membership, as well as its specific provisions (especially with regards to expropriation). Furthermore, the significant body of case law around the Energy Charter Treaty could also not be ignored. Not to mention the horizontal issues surrounding energy-exporting countries. Only following all this data was collected and processed, could I turn to answering the questions. Finally, after the questions have been answered, it is necessary to study their applicability to Iraq.

\subsubsection{Aims of the research}

The Energy Charter Treaty is undoubtedly a well-established treaty, a gold standard of the energy sector from the perspective of investment protection at the very least, so there needs to be some justification for its further research, as the literature surrounding it is quite wellestablished. This justification is based on a specific perspective, connected to my personal background.

In recent years, my home country of Iraq, and specifically the Kurdistan Region of Iraq, has been attempting to modernize its energy industry and fostering its participation in energy trade. Iraq occupies a prominent place as one of the most important oil exporters in the world, ranking 3rd in crude oil exports worldwide. However, it is also a country with a difficult political climate, fraught with tension, and as explained in the beginning of the dissertation, one that could significantly benefit from foreign investment in their energy sector and infrastructure. After the fall of the pre-2003 regime, Iraq stands at the crossroads, as internal conflict and disagreements hamper efforts to rebuild and modernize. Due to the political situation, Iraq is also strongly in the United States of America sphere of influence, and this has an undeniable effect on domestic politics and economic policies as well. The best way to accomplish its economic objectives is undoubtedly through foreign 
capital. However, most foreign investors can be difficult to attract, and require several guarantees before they are willing to invest in the target country, due to their cautiousness. Domestic guarantees are easily revoked, therefore I believe that international agreements would be the most efficient way of accomplishing this.

Iraq, is not a contracting party of the Energy Charter Treaty. Therefore, I believe it is important to examine the Energy Charter Treaty based on the above, to determine whether it would be beneficial for his country to adopt it, as part of the country's transition into being a more open economy, with closer ties to the world market, especially in energy. Another reason for this research is that my home region, the Kurdistan Region of Iraq, is heavily reliant on Turkey as a transit country for exporting their energy resources. I wished to examine whether the adoption of the Energy Charter Treaty (of which Turkey is a signatory party), would help stabilize energy relations. The Kurdistan Region is also an autonomous region in Iraq, and an area which could also significantly benefit from accession to the Energy Charter Treaty. Foreign investment attracted to the region could fuel an economic boom, which would ensure a steady increase in the economic sustainability. Due to the nature of legal framework and political agreements in Iraq, the Kurdistan Region is permitted to establish its own investment law regime. It has done it in 2006, and it is an important factor from the perspective of foreign investors. However, as noted before, domestic guarantees are usually insufficient for foreign investors before they are willing to take the risk of investing in a host country. Thus, given this domestic situation, becoming a part of the Energy Charter Treaty would further help with the stability of the country. Foreign investors look for stability when deciding where to make their investments, and through the Energy Charter Treaty, Iraq could reinforce the image of stability. Therefore, the Energy Charter Treaty would make Iraq more attractive to foreign investments, and thus help in the development of the country towards a more prosperous future. Due to transit as an issue having its own expansive and separate scholarship and research, I will focus my work purely on the investment aspects of the treaty as detailed above.

Furthermore, as for the location of my research, it can easily be connected to Hungary. Hungary is member of the Treaty and it might happen that Hungary will seek alternatives to Russian natural gas. In this case, the Kurdistan Region of Iraq could provide an ample source of natural gas. However, these pipelines would naturally have to cross Turkey, 
which raises another transit issue that could be potentially solved through the Energy Charter Treaty.

\subsubsection{Methodology}

Regarding methodology, I focused on using qualitative research. That is instead of raw numbers and measures, my focus has been on examining and detailing the specific theoretical and practical aspects of my subject, in order to establish the necessary background for drawing conclusions about the above-mentioned central premise. To list a few examples of my used sub-methodologies, I used the historical method, as I considered it important to examine the historical background of the Energy Charter Treaty. In particular, I looked at the precedents of the Energy Charter Treaty, their formation, how the Energy Charter Treaty itself came to being, how it evolved after coming into force and what issues it faced since then. This was something I believed to be quintessential to my dissertation, that it was a necessity in order to understand the real goals behind the establishment of the Treaty and the challenges facing it from its inception to its present. Thus, I would be able to demonstrate how it developed and evolved over time.

Secondly, I used descriptive methods. In subjects such as investment, investor, foreign investment, expropriation, compensation and dispute settlement, it was necessary for the logical structure of my research to describe these subjects in precise details. Besides the Energy Charter Treaty, I also looked at other relatable definitions and concepts as defined by other sources. This provided an opportunity to demonstrate differences and similarities between how general international thought, other treaties and the Energy Charter Treaty defined these subjects. For the purposes of the research, I did not consider it necessary to indulge in a true comparative analysis, but that the different interpretations as demonstrated should serve the reader well enough in understanding the fundaments of the subject matter at hand. However, the emphasis was fixed on the Energy Charter Treaty's interpretation, as per the central premise of measuring its comprehensiveness, advantageousness and efficacy from the perspective of Iraq.

Furthermore, I relied on the analytical method to determine and understand the critical problems and issues of the Energy Charter Treaty (in relation to investment protection, of 
course), and whether it would be beneficial for Iraq to adopt the Energy Charter Treaty and whether such a treaty benefits energy exporting countries or not. In relation to this, I undertook the analysis of several energy exporting countries, from the perspective of the Energy Charter Treaty, including Iraq itself.

Moving on, I also examined the case law surrounding the Energy Charter Treaty. This, both showed him the general practice, and allowed him to demonstrate the common issues and questions surrounding the investment protection aspect of the Energy Charter Treaty. In particular, I examined all available case law related to Articles 10 and 13 of the Energy Charter Treaty, so the focus was on expropriation from the perspective of cases.

Based on this case law, I engaged in a bit of a conceptual research about why foreign investors sue host countries under the Energy Charter Treaty.

On a lesser note, I also used some quantitative research, regarding the issue of compensation in international practice, where I examined various statistics in order to compare compensation sums under the Energy Charter Treaty with compensation sums under other treaties and general international investment practice.

\subsubsection{Structure of the research}

In total, I separated my dissertation into seven different chapters. In this first chapter, I first discussed the most important aspects of my research, and my approach to the research questions. Afterwards, I went over the basics of the Energy Charter Treaty. In particular, I examined the history, evolution and aims of the Energy Charter Treaty, with focus on precedents (such as the European Energy Charter), the formation of the Energy Charter Treaty itself, and further developments. I emphasized that the aim of the Energy Charter Treaty was fundamentally to satisfy mutual needs between parties (energy for importing countries, capital for exporting countries) and out of a general desire to create a new meaningful economic relationship between the West and the former Eastern Bloc, though the scope expanded significantly to include other developing countries as well. Some of the contracting parties to the treaty were detailed by me next, with particular focus on Russia, who had several issues with the Energy Charter Treaty, especially in relation to transit. Finally, I also addressed the structure of the Energy Charter Treaty in the first chapter. 
In the second chapter, I focused on presenting and examining dispute settlement mechanisms under the Energy Charter Treaty. First, I undertook a short comparative analysis of what makes investor-state dispute settlement (that appears in the Energy Charter Treaty) different from the regular and typical international commercial arbitration regime. Afterwards, I went onto details regarding what the Energy Charter Treaty says about such investor-state disputes, before concluding it with a short section on dispute settlement between the contracting parties themselves.

In the third chapter, I addressed some horizontal issues and examined the Energy Chapter Treaty from the perspective of energy exporting countries. I separated the group into contracting parties and non-contracting parties, with eight countries being examined in total. I also attempted to conceptualize reasons and explain why these countries joined or did not join the Energy Charter Treaty, and whether the ECT has been beneficial to them or not.

In the fourth chapter, I addressed the promotion, protection and treatment of investments and the issues of expropriation and compensation. In particular, I examined the concept of investment and investor, and their definitions under the Energy Charter Treaty. Secondly, I went over expropriation, with focus given to the conditions of lawful expropriation under international law and the definitions given in the Energy Charter Treaty. I then examined the standard of compensation for expropriation in investment treaties in a descriptive manner, with the focus being once more on the Energy Charter Treaty. Finally, in the second half of the chapter, I examined in-depth the case law related to Articles 10 and 13 of the Energy Charter Treaty, and thus the case law relevant to the issue of expropriation. However, I made one exception regarding this, and briefly described a non-Energy Charter Treaty-related case, because it also dealt with the issue of expropriation heavily and contained useful information regarding the concept, with a separate placement from the rest of the Energy Charter Treaty-related case law.

In the fifth chapter, after laying the groundwork in the previous four chapters, I sought to answer the three research questions. Whether the Energy Charter Treaty sufficiently guarantees the protection of foreign in-vestments, and if so, to what extent? Whether the compensation paid under the Energy Charter Treaty is comparable to international practice? Whether the Energy Charter Treaty has a "regulatory chill" effect? In the first case, I examined the situation before the Energy Charter Treaty briefly, before approaching relevant 
articles from a different direction than in the previous chapter, and analyzed the existing arbitral practice. In the second, I separated my work into two segments: first, I examined compensation from a theoretical perspective, then sought to compare raw data between general international practice and the Energy Charter Treaty, with regards to success rate of claiming compensation and how much compensation is typically claimed, and rewarded by arbitration. And for the third question, I examined regulatory chill and treaty law, the right to regulate, or the interplay between public policy issues and investor protection, and the overall recipe for regulatory chill.

In the sixth chapter, I addressed Iraq's position in the energy sector from an investment protection perspective, with specific focus on the Kurdistan Region of Iraq and its domestic law on investment.

Finally, in the seventh chapter, I summarized my answers to the three research questions and addressed one of the central premises, that is: whether the Energy Charter Treaty would be a beneficial arrangement for Iraq and the Kurdistan Region of Iraq in particular.

\subsection{The Energy Charter Treaty}

\subsubsection{History, evolution and aims}

The Energy Charter Treaty (hereafter the Energy Charter Treaty or Treaty) is a unique multilateral investment treaty, the primary goal of which is the promotion of long-term international cooperation in the energy sector. It affects energy investments in foreign markets made by energy suppliers, including the oil and gas industry. The main aim of the Energy Charter Treaty, per its preamble, is to "liberalize investment and trade in energy". However, many authors agree that its main achievement is the regulation of the legal pro- 
tection of foreign investments. ${ }^{1}$ The Energy Charter Treaty emerged after the end of the Cold War in the 1990's and came into force on April 12, 1998. ${ }^{2}$ During that time, European states found that they had robust economies, but lacked energy resources, while Russia and other post-Soviet states had energy resources, but lacked investment to rebuild their economy. ${ }^{3}$ Developing nations had a desire to modernize their energy sector while energy resources were and are one of the few sources of reliable, direct, foreign currency for these countries. ${ }^{4}$ This created the need for a new, mutual energy- and capital-based relationship and so an international framework regulating foreign energy investment in this field of economy was deemed necessary to achieve this.

Before explaining the creation of the Energy Charter Treaty, it would be prudent first to study deeper the undercurrents mentioned above (developed Western economies in need of energy, energy-rich but poor Eastern European states), and show how the precedents of the Energy Charter Treaty evolved.

After the collapse of the Soviet Union's sphere of influence, the Dutch Prime Minister, Mr. Lubbers, was the first to call for a European Energy Charter in 1990. This charter was to serve as the foundation of a new relationship between the East and the West, one in the spirit of cooperation and mutual prosperity, which would increase regional political stability and help the former socialist countries in their transitionary period. ${ }^{5}$ Despite the somewhat optimistic message, this call cannot be purely construed as optimistic. Instead, it was motivated by the interests of Western governments and business, and economic actors, as mentioned above.

Let me delve deeper into the motivations behind these interests that were referred to at the beginning of this part. Western Europe was energy dependent, and it was heavily in its in-

\footnotetext{
${ }^{1}$ OECD, 'Protecting Investment Legal Frameworks for Infrastructure Investment in Egypt, Jordan, Morocco and Tunisia' (2014) 13. <https://www.oecd.org/globalrelations/Legal\%20Study_EN.pdf $>22$ accessed May, 2017

${ }^{2}$ Graham Coop, Energy Dispute Resolution: Investment Protection, Transit and the Energy Charter Treaty (Juris Publishing, Inc., 2011) 192

${ }^{3}$ Iuliana-Gabriela Iacob, Ramona-Elisabeta Cirlig, 'The Energy Charter Treaty and Settlement of Disputes - Current Challenges' (2016) 6.1 Juridical Tribune 72

${ }^{4}$ Rima Turk, Financial Decisions and Investment Outcomes in Developing Countries: The Role of Institutions (International Monetary Fund, 2015) 17

${ }^{5}$ Craig Bamberger, Jan Linehan \& Thomas Waelde, The Energy Charter Treaty in 2000: In a New Phase (Oxford University Press, 2000) 2
} 
terests to secure a supply of energy and to safeguard it from potential threats. Therefore, the creation of a stable and privileged energy investment framework with the energy-rich post-Soviet nations was a logical step towards realizing this goal. Through Western investments, Eastern economies could develop and supply the West's energy needs in a steadfast manner. Through such a charter, financial capital and technology would flow eastward from the Western nations, while Eastern countries would provide its energy and products to the Western markets. ${ }^{6}$ The economic reasoning behind the call of Prime Minister Lubbers is thus clear. Europe at this point was at a crossroads, a truly historic period, and Western business interests were apparently determined to seize this opportunity for their own profit and for general prosperity.

Pressing on with the chronological events; Mr. Prime Minister Lubbers' call was positively received by the European Council which resulted in the European Council asking the Commission of the European Communities to study how best such a charter and co-operation that Mr. Lubbers called for could be achieved. This led to the proposal of a charter by the Commission in February 1991. This proposal by the Council was first discussed by the Council of the European Communities, which favored it. This, in turn, led to the European Union calling together a conference in Brussels in July 1991, with the intent of negotiating this new European Energy Charter. The European Union invited the other countries of Western and Eastern Europe, the former Soviet republics, and also the non-European members of the OECD. Later, the United States of America, Japan, Canada and Australia all joined the negotiations. ${ }^{7}$ This shows that despite the originally European nature of this charter (as evidenced by its name of "European Energy Charter"), it had attracted significant global attention, as can be seen from the involvement of the OECD countries, as well as the United States of America, Japan, Canada and Australia, all of which were significant players in the world energy market.

This first crucial step towards greater energy co-operation was the signing of the European Energy Charter, which finally happened on 17 December 1991 in The Hague ${ }^{8}$ which

\footnotetext{
6ibid

$7_{\text {ibid }}$

${ }^{8}$ Energy Charter, 'The Energy Charter Treaty - a Reader's Guide' (2004) 5 OGEL <www.ogel.org/article.asp? key $=1622>$ accessed 03 June 2017
} 
showed a remarkably rapid pace of negotiations. Prime Minister Lubbers' call was only in 1990, and yet the Commission finished its proposal, the European Union called its conference, and already a resolution of sorts was reached in a year's time. However, it must be stressed that this was a non-binding agreement that contained a set of guidelines, protocols as well as signposts, for the negotiation of the future Energy Charter Treaty... Despite it having only 15 signatories and being a non-binding agreement consisting of mostly polity goals and general goodwill, the charter foreshadowed the increased negotiations to develop a more comprehensive and universal energy charter. Seeking to expand the protections of the Energy Charter Treaty to countries outside of Europe, these signatories began negotiating for a broader agreement that would include more nations. Much of the provisions in the European Energy Charter are included in the Energy Charter Treaty. ${ }^{9}$ Based on the latter mentioned the European Energy Charter can be considered the immediate predecessor of the Energy Charter Treaty. Despite its lax and ultimately non-binding nature, lack of precise rules, and being mostly based on hazy expressions of interest in further cooperation for mutual prosperity, the European Energy Charter can still be considered an important milestone, a landmark for the development of cooperation in the field of energy and investment. As mentioned before, the set of principles it established had significant influence on the later, much more pervasive and important Energy Charter Treaty.

Formal negotiations for the Energy Charter Treaty began in 1992, as some negotiation already took place by the time of the signing of the non-binding European Energy Charter. The negotiating process was hampered by numerous struggles and problems, such as different perspectives between Western and Eastern countries, as well as differing opinions and conflicts within the OECD membership itself. All of these conflicts significantly lengthened the negotiation period. ${ }^{10}$ This illustrated that regardless of the remarkably fast pace of negotiations for the non-binding agreement, concluding an actually binding treaty was far more difficult.

Showing the problems with negotiating such a far-reaching and ambitious agreement with a large number of countries, the negotiation teams were composed of 50 delegates from an

\footnotetext{
${ }^{9}$ Graham Coop, Energy Dispute Resolution: Investment Protection, Transit and the Energy Charter Treaty (Juris Publishing, Inc., 2011) 257

${ }^{10}$ Craig Bamberger, Jan Linehan \& Thomas Waelde, The Energy Charter Treaty in 2000: In a New Phase (Oxford University Press, 2000) 3
} 
array of different backgrounds and specialties. The eventual success of the negotiations and the end of this deadlock was a result of two different factors. First, there was a significant debate about applying the national treatment standard at the pre-investment stage. Russia and the former Soviet republics were unfamiliar with this standard, and had no internal legislation to provide exceptions for it in sensitive domestic areas. These parties were suspicious of more wily countries, such as the OECD members, sneaking in disadvantageous clauses later on if this application was accepted. The European Union managed to resolve this potential issue by suggesting the deferment of the subject to a "second phase" treaty. This was accepted by the parties involved. ${ }^{11}$ Here we can see that the primary engine of progress when it came to the negotiations was the European Union. Which is not surprising as not only the conference was held at the arguable center of power for the European Union, the entire treaty started out as a brainchild of the Dutch Prime Minister, Mr. Lubbers, and the Commission.

The second factor that led to the conclusion of the negotiations was the increasing discomfort and stress resulting from the seemingly pointlessly prolonged negotiations. The Commission, which provided financial support to the conference, as well as many other negotiating parties, started growing impatient with the overall lack of progress in the negotiations. The leadership of the conference also had great trouble coordinating and maintaining the temporary secretariat that was set up for the duration of the conference. Thus, this leadership took a gamble, and decided to set up a deadline for the conclusion of the negotiations. This was successful, and produced several tangible treaty commitments from most negotiating parties. ${ }^{12}$ In my opinion, the success of this deadline showed that the parties were significantly more vested in producing actual, meaningful results for the conference, than they were in maintaining their original positions and stubbornness.

In conclusion, these two factors eventually allowed the negotiating parties to come into some form of mutual agreement over the major provisions of the treaty, and ultimately produced what would be called the Energy Charter Treaty. Without the witty suggestion of the European Union about deferring the subject of national treatment at a pre-investment

\footnotetext{
${ }^{11}$ ibid

12 ibid
} 
stage, and without the deadline set by the conference leadership, it is highly unlikely that the Energy Charter Treaty would have been born at all.

After 3 years, the Energy Charter Treaty remained open for signature for six months, starting from December 17, 1994 in Lisbon Portugal. During this period, it was signed by 49 countries and the European Union, including almost all European nations and former Soviet republics, as well as Japan and Australia. While they signed the earlier non-binding European Energy Charter, Canada and the United States of America opted to remain as observers of the Energy Charter Treaty, instead of full contracting parties. As it was already mentioned, the Energy Charter Treaty entered into force in $1998 .{ }^{13}$

Besides the origins and history of the Energy Charter Treaty, this segment is also about the very evolution of the treaty. Therefore, it is prudent to write about the previously mentioned second phase negotiations, which was suggested by the European Union during the negotiations.

The Energy Charter explicitly referred to this second phase of negotiations as a "Supplementary Treaty" in various paragraphs of Article 10. The negotiations for this accompanying treaty were to begin on January 1, 1995 and were to be concluded by January 1, 1998 at the very latest. Besides the original issue that prompted this second phase, an understanding in the Energy Charter Treaty's Final Act also mandated that this supplementary treaty was to include provisions about de-monopolization and privatization, specifically how the Energy Charter Treaty should be applied in cases these phenomena occurred. This second phase treaty was also to include so-called best efforts obligations of standstill and liberalization, in connection with investments in the energy sector. ${ }^{14}$ The inclusion of these provisions is logical because after the collapse of the Soviet regime, many Eastern European countries and former Soviet republics had strictly controlled and had legislation on state-owned enterprise, which were responsible for the energy sector. Many of these operated at a net loss, thus liberalization, privatization and de-monopolization were natural

\footnotetext{
${ }^{13}$ Richard L. Wallace and others, The Marine Mammal Commission compendium of selected treaties, international agreements, and other relevant documents on marine resources, wildlife, and the environment (Washington, D.C., The Commission, 1999) 154

${ }^{14}$ Craig Bamberger, Jan Linehan \& Thomas Waelde, The Energy Charter Treaty in 2000: In a New Phase (Oxford University Press, 2000) 23
} 
choices during the transitioning of the economic model towards a more capitalistic, free market-based one.

Despite these negotiations concluding by December 1997, issues remained; in particular, the EU was uncomfortable with the inclusion of some OECD countries in the Annex. Two further sessions of the conference were held, during which the negotiating parties made significant progress. However, these sessions also revealed further issues as in June 1998, beyond the original deadline set by Article 10 of the Energy Charter Treaty, the EU stated that it was not yet in a position to adopt the proposed supplementary treaty. And that this was due to internal domestic political pressure within EU member states, particularly from labor and environmental interests. Furthermore, three countries (Norway, Australia and Iceland) were strongly opposed to the inclusion of investor-state dispute settlement provisions in the supplementary treaty. Due to these obstacles, the proposed second phase investment supplementary treaty did not manifest in the original timeframe envisioned by the parties. ${ }^{15}$ In my view, this shows that investment-related issues are an extremely controversial topic in most European countries, with a public hostile and suspicious of investmentrelated treaties, which resulted in the domestic pressure experienced by the European Union, in connection with the supplementary treaty.

However, it is worth mentioning that despite these setbacks, this was just one of several second phase negotiations. In April 1998, for example, an Amendment to the Trade-Related Provisions of the Energy Charter Treaty was adopted. This amendment updated the 1947 GATT regime to the then-modern World Trade Organization rules. ${ }^{16}$ As mentioned above, it is not surprising at the least that non-investment related rules and aspects are much less of a sensitive topic, and thus progress is made much quicker.

Furthermore, when it comes to the evolution of the Energy Charter Treaty, the December 2009 Rome Conference stands out, as this was the point where it was decided by the contracting parties that significant steps are necessary to modernize and advance the Energy Charter Treaty, in light of the issues with the Russian Federation (to be discussed in the

\footnotetext{
$15_{\text {ibid }}$

${ }^{16}$ Andrei Konoplyanik, Thomas Wälde, 'Energy Charter Treaty and its Role in International Energy' (2006) Vol 24 No 4 Journal of Energy and Natural Resources Law 524
} 
next part). ${ }^{17}$ These modernization efforts led to the signing of the International Energy Charter on May 20, 2015. As mentioned before, the International Energy Charter is primarily a political declaration of various goals and principles that relate to the modernization of the Energy Charter Treaty. ${ }^{18}$

After discussing the origins and the evolution of the Energy Charter Treaty, it is now prudent to close this segment with a short discussion of the Energy Charter Treaty's goals and aims.

In general, the goal of the Energy Charter Treaty is to provide a comprehensive and holistic legal framework for the production, transport, and delivery of energy products. ${ }^{19}$ It is a syndissertation of what bilateral energy treaties were trying to achieve in the first place, such as definitions of what an investor is, safeguard clauses, and the proper method of settling disputes. This syndissertation allows it to achieve a uniquely important position when it comes to energy-related investments. The goals detailed earlier in this segment also apply.

Despite fundamentally being an international treaty of an economic character, the Energy Charter Treaty also refers to the issue of environmental protection. ${ }^{20}$ First of all, already in the preamble, it refers to multilateral environmental treaties. This is also complemented by Article 19, which states that "parties shall strive to minimize in an economically efficient manner, the harmful environmental impacts of the activities in the energy sector, including through precautionary measures where appropriate, and taking into account the polluterpays principle". Although this provision falls outside of the scope of Article 26 and 27 concerning dispute settlement, Article 19 gives due attention to serious environmental concerns which may have otherwise been ignored.

This provision is also supplemented by the Protocol on Energy Efficiency and Related Environmental Aspects (PEERA) which enters more into details about environmental protec-

\footnotetext{
${ }^{17}$ Urban Rusnák, 'Modernization of the Energy Charter' (Russia in Global Affairs, 27 December 2013) <http:// eng.globalaffairs.ru/number/Modernization-of-the-Energy-Charter-16294> accessed 02 November 2017

18'International Energy Charter' <http://www.energycharter.org/process/international-energy-charter-2015/overview/> accessed 02 November 2017

${ }^{19}$ Julia Selivanova, Regulation of Energy in International Trade Law: WTO, NAFTA, and Energy Charter (Kluwer Law International, 2011) 397

${ }^{20}$ Saverio Di Benedetto, International Investment Law and the Environment; Elgar International Investment Law series (Edward Elgar Publishing, 2013) 196
} 
tion. PEERA was an early addition to the Energy Charter Treaty, as it was signed in December $17,1994 .^{21}$

In conclusion, we can see that the fundamental goals of the Energy Charter Treaty are multifold. The original core issue was to help the transition of former Soviet republics and Eastern Europe into capitalist economies, and help the development of their energy production capacities, while also ensuring the energy supplies of the West. This goal in time developed into a more general goal of ensuring global cooperation in the world energy market, through establishing this general legal framework, substituting the bilateral treaties such cooperation would otherwise require. Furthermore, the question of environmental concerns cannot be looked away and the Energy Charter Treaty clearly establishes resolving the dilemma between energy production and the environment as a core aim.

\subsubsection{Parties}

As of January 1, 2018, 54 countries have signed the treaty. ${ }^{22}$ Out of these parties, the largest economies are the European countries like the United Kingdom, and Germany. ${ }^{23}$ These countries benefit the most from the Energy Charter Treaty, as they are the most important investors in oil-rich developing countries, and they have the highest amount of import and export compared to the rest of the members. ${ }^{24}$ Other parties of the Energy Charter Treaty with highly developed economies include Switzerland, Belgium, France, and Spain. ${ }^{25}$ As it can be seen from these examples, the non-energy rich countries primarily

${ }^{21}$ Andrei Konoplyanik, Thomas Wälde, 'Energy Charter Treaty and its Role in International Energy' (2006) Vol 24 No 4 Journal of Energy and Natural Resources Law 524

\footnotetext{
${ }^{22}$ 'Energy Charter Treaty' <https://energycharter.org/process/energy-charter-treaty-1994/energy-charter-treaty>
} accessed 05 May 2018

${ }^{23}$ David Shepherd \& Aubrey Silberston \& Roger Strange, British Manufacturing Investment Overseas (Routledge Library Editions: International Business, Routledge, 2013) 21-25

\footnotetext{
${ }^{24}$ According to the CIA World Factbook, The European Union (EU), though a bloc of countries rather than a single nation, has over $\$ 5.14$ trillion in direct FDI stock as of 2012. It is $1^{\text {st }}$ in the world in exports with over $\$ 2.259$ trillion in revenue, while being the $2^{\text {nd }}$ in the world in imports, with $\$ 2.244$ trillion in imports as of 2014 , respectively. Germany and the United Kingdom (UK) the $2^{\text {nd }}$ and $3^{\text {rd }}$ largest economies of members in the Energy Charter Treaty. Germany is alone an economic powerhouse, with FDI stock valued at $\$ 1.36$ trillion, and ranking $4^{\text {th }}$ in the world in exports and imports with $\$ 1.309$ trillion and $\$ 1.017$ trillion as of 2015 . The UK, who's future is uncertain after the recent Brexit vote, still has over \$2.04 trillion in FDI stock, exports at \$436.2 billion (as of 2015), while importing \$627.7 billion. Source: Central Intelligence Agency, The world Factbook; United Kingdom, <https://www.cia.gov/library/publications/the-world-factbook/geos/uk.html> accessed 21 May 2017
}

\footnotetext{
${ }^{25}$ Thomas Walde, The Energy Charter Treaty:An East-West Gateway for Investment and Trade (Kluwer Law International, 1996) 144
} 
interested in being parties of the Energy Charter Treaty are those that are dependent on energy imports to fuel their highly developed economies, and thus require a favorable framework for this purpose.

The largest energy exporting nations benefitting from the protections of the Energy Charter Treaty are Kazakhstan and Norway. ${ }^{26}$ Norway exports approximately 1.68 million barrels of oil per day and is ranked $14^{\text {th }},{ }^{27}$ but also 9 th in the world in electricity exports. ${ }^{28}$ Kazakhstan exports roughly 1.355 million barrels of oil per day and is ranked 12th..$^{29}$ These two countries benefit greatly from protections provided under the Energy Charter Treaty, but due to low global oil prices, investment has been slower than before. ${ }^{30}$

Another member country that is a significant energy exporter is Turkmenistan, which is ranked $7^{\text {th }}$ in natural gas exports. The Netherlands, being ranked $6^{\text {th }}$ in natural gas exports, is also members of the Energy Charter Treaty. ${ }^{31}$

However, several globally important energy exporters such as Algeria, ranking $9^{\text {th }}$ in natural gas exports, are merely observers of the Treaty, instead of being full members. ${ }^{32}$ This phenomenon might be the result of various reasons; for example, it is possible that some of the primary energy exporters are so dependent economically on their energy exports, that they would rather maintain full legislative and directive control of their energy industries, instead of chancing an unfavorable situation arising from the Energy Charter Treaty.

The listed countries are very different both geographically and economically, but all are important energy exporters. Based on these examples, it can be stated that countries with significant energy exports (be they developed or developing economies) are also signifi-

\footnotetext{
${ }^{26}$ Ilias Bantekas, John Paterson, Maidan Suleimanov, Oil and Gas Law in Kazakhstan: National and International Perspectives ( Kluwer Law International, 2004) 54

${ }^{27}$ Energy Department, Annual Energy Review 2008 (Government Printing Office, 2009) 315

${ }^{28}$ Jorge Morales Pedraza, Electrical Energy Generation in Europe: The Current and Future Role of Conventional Energy Sources in the Regional Generation of Electricity (Springer, 2014) 146

${ }^{29}$ United States. Office of Energy Markets and End Use, Short term energy outlook: Quarterly projections (The Office, 1995) 25

${ }^{30}$ Henry K. H. Wang, Energy Markets in Emerging Economies: Strategies for growth, (Routledge, 2016) 96.

31'CIA World Factbook' <https://www.cia.gov/library/publications/the-world-factbook/rankorder/ 2251rank.html> accessed 10 November 2017

32 'CIA World Factbook' <https://www.cia.gov/library/publications/the-world-factbook/rankorder/ 2251rank.html> accessed 10 November 2017
} 
cantly vested in being either parties or observers of the Treaty, depending on how they view the Energy Charter Treaty.

Russia should be also mentioned here, as it is the world's $2^{\text {nd }}$ energy exporter, ${ }^{33}$ with over 4.594 million barrels of oil exported per day. Russia has signed the Treaty, but in November 2009, the Russian Federation decided not to ratify it. Originally, the Russian Federation was invested in participating in the Energy Charter Treaty due to a desire to acquire guidelines about market regulations of the energy sector. Furthermore, it was also seeking to attract investment and obtain the technology that was necessary to restore its levels of oil and gas production to the previous levels. ${ }^{34}$ As discussed in the previous segment, the Energy Charter Treaty was in general a result of the desire towards a mutual system of symbiosis between Western energy needs and Eastern hunger for products and capital. In many ways, it can be considered that the Russian Federation's interest in the Energy Charter was an archetypical example of this symbiotic goal.

However, Russia always had a significant problem relating to the Energy Charter Treaty that requires mentioning here. The central subject for Russia's energy policy and goals was always the question of transit due to transit thefts and tariffs. Article 7 (1) of the Energy Charter Treaty deals with energy transit, which used the term 'facilitate' in relation to transit in an unclear manner. In order to clarify the meaning of these provisions, a Transit Protocol was suggested by the Energy Charter Conference in 2000. This protocol included the definition of access to pipelines, the cost-effectiveness of transit tariffs and the definition of available capacity and transit theft. ${ }^{35}$ The need for this protocol showcases the unavoidable difficulties and inexact wordings for such ambitious treaties as the Energy Charter Treaty.

The Transit Protocol served as the primary point of friction between the EU and Russia concerning the Energy Charter Treaty. Russia wanted the Protocol to include the 'right of first refusal', provided a long-term supply contract does not match the long-term transit

\footnotetext{
${ }^{33}$ IBP, Inc, Russia Energy Policy laws and Regulations Handbook, vol 1 (World Business and Investment Library, 2015) 59.

${ }^{34}$ Irina Pominova, Risks and Benefits for the Russian Federation from Participating in the Energy Charter: Comprehensive Analysis (Energy Charter Secretariat Knowledge Centre, 2014) 5

${ }^{35}$ Andrei V. Belyi, A Russian Perspective on the Energy Charter Treaty (Real Instituto Eleano, 2009) 3
} 
contract. This position was deemed unacceptable by the EU, because it desired to see both transit and supply contracts drastically shortened, so as to enhance competition. This has resulted in postponement of the Transit Protocol signing. This was the primary cause why Russia refused to ratify the Energy Charter Treaty, as even in 2001, the Russian Parliament stated that the ratification of the Energy Charter Treaty was contingent on a proper transit agreement within the Energy Charter Treaty. ${ }^{36}$ The primary reason for this difference in opinion is due to the Russian perception of the Energy Charter Treaty as being an EUsponsored treaty fundamentally, as evidenced by its origins (discussed in the previous segment). Furthermore, during the Protocol negotiations, the EU devised a method by which it could exempt itself from certain obligations in the Energy Charter Treaty, while imposing those very same bypassed obligations on the Russian Federation. ${ }^{37}$ In my opinion, it can be concluded that there was a fundamental difference between the goals and ambitions of the two parties, which when combined by the general lack of trust exhibited by the Russian government towards Western interests, in particular, the EU, it is not surprising that Russia has decided to not ratify the Energy Charter Treaty, which it views as the brainchild of the EU.

All of the issues listed above have created a major challenge in the relationship between the European Union and Russia in the context of energy investment relations. One of these most controversial additions to Energy Charter Treaty provisions, besides the Transit Protocol mentioned above is the Third Energy Package, which introduces an "unbundling" scheme to restrict vertically integrated competitive companies from hampering a transparent, competitive market. Companies must choose among three options which separate ownership, supply, generation, and production undertakings requiring that some of these components must be independent of the company itself. The aim of the European Union Commission was to enhance competitiveness and consumer protection (echoing their goals in the Transit Protocol). This was viewed as discriminatory and damaging by Gazprom, the Russian state oil company. The troubles became apparent in the case of Yukos v Russian Federation, where the Arbitral Tribunal sided with the claimant which greatly angered the Russian government. Russia tried claiming that it was not bound by the Energy Charter

\footnotetext{
36ibid 3-4

37ibid 4-5
} 
Treaty since it refused to ratify the treaty in 2009 , but because it had signed the treaty in 1994, it was bound by any investment during the period of 2004-2009 by virtue of Article 45 of the Energy Charter Treaty ${ }^{38}$. All of this have led to the 'withdrawal' of the Russian Federation from the Energy Charter Treaty, meaning that the Russian government has adopted a decreed, which (based on the Vienna Convention on the Law of Treaties 1969) stated that Russia no longer intends to become a party of the Energy Charter Treaty. ${ }^{39}$ In conclusion, we can make a few general observations about Energy Charter Treaty parties. First, that the primary focus of the Energy Charter Treaty being East-West energy relations is reinforced by the fact that most significant energy exporters that do not fit into this dichotomy are merely observers of the Treaty, instead of being parties. This shows the EUfocused nature of the Treaty. Furthermore, we have seen the Russian issues with the Energy Charter Treaty, and thus have glimpsed into the inadequacies of the Treaty itself, despite its ambitious and optimistic origins.

\subsubsection{Structure of the Energy Charter Treaty}

The Energy Charter Treaty is structured into several parts which will be examined in depth further in this work. Part I contains the Definition and Purpose of the treaty. Part II contains matters related to commerce with regards to international markets, the WTO, and trade related investment measures. Part III contains the investment protections that are the focus of this work. Part IV contains miscellaneous legal provisions concerning issues such as sovereignty over energy resources, environmental aspects, transparency, taxation, and others. Part V provides the dispute settlement mechanism, namely the arbitration process and procedure in case of a dispute between host states and investors. Part VIII contains the structure and institutions that govern the Energy Charter Treaty. Lastly, Part VIII contains other procedural matters surrounding the Energy Charter Treaty.

\footnotetext{
${ }^{38}$ Yukos Universal Ltd. (UK Isle of Man) v Russian Federation UNCITRAL, PCA Case No. AA227 109

${ }^{39}$ White \& Case LLP, 'Russia Rejects the Energy Charter Treaty' <https://www.lexology.com/library/detail.aspx? $\mathrm{g}=540 \mathrm{~d} 55 \mathrm{eb}-83 \mathrm{a} 7-4719-\mathrm{a} 03 \mathrm{c}-9 \mathrm{de} 6643169 \mathrm{~b} 0>$ accessed 11 November 2017
} 


\section{Dispute settlement mechanism under the Energy Charter Treaty}

As we are going to examine the case law of the Energy Charter Treaty, it is necessary to discuss the dispute settlement system of the Treaty. Like the majority of multilateral treaties or bilateral treaties between international subjects, Energy Charter Treaty contains two kinds of dispute settlement systems. One is for disputes which arise between the host country and the foreign investor, while the other one is for disputes between the contracting parties. The first one is regulated in Article 26, while the latter one is regulated in Articles 27-28 of the Treaty. We are going to examine first those provisions contained in Articles 26 and 27, but before that, it would be worthwhile to do a general comparison between what distinguishes investor-state arbitration from commercial arbitration. This way, the reader will be able to understand why exactly Articles 26 and 27 contain such provisions as they do.

\subsection{Comparing investor-state dispute settlement and commercial arbitra- tion in general}

Investor-state arbitration has several important similarities with international commercial arbitration. Both are conducted based on the consensus of the disputing parties, and involves decisions by arbitrators, selected for the specific dispute by the parties, which resolve said dispute in a final and binding manner. Furthermore, investment arbitration is typically conducted either based on specialized institutional rules that have been modeled on commercial arbitration rules or pursuant to generally applicable institutional rules designed mainly for international commercial arbitrations. ${ }^{40}$ Still there are some differing characteristics, which is especially true of arbitrations conducted under the very frequently utilized ICSID Convention, but is also usually true of investor-state arbitrations under various Bilateral Investment Treaties and other treaty systems (including the Energy Charter Treaty, but see the next section for more details on that particular part).

To begin with, international commercial arbitration almost always involves disputes between private parties. But the parties are mixed in investor-state arbitration: we have the host state (a subject of international law) and an investor (typically a corporation subject to

\footnotetext{
${ }^{40}$ Gary B. Born, International Arbitration Law and Practice (Kluwer Law International, 2012) 503
} 
another state's domestic law). ${ }^{41}$ To continue with substantive issues considered by the arbitrators, international commercial arbitrations typically involve contractual claims, so they usually focus on issues of contract interpretation and applicable national/domestic law. Hence, these cases rarely become public. In contrast, investor-state arbitration typically involves international treaties, usually Bilateral Investment Treaties or a multilateral treaty like the Energy Charter Treaty, but the influence of international customary law also cannot be disputed. ${ }^{42}$ As a result, investment arbitration cases usually focus on issues of interpreting international law and treaties. This necessitates the creation of a large body of special investment case precedents, due to the ambiguity of these sources, and so they must be public for the arbitrators to access them as points of reference. Hence, confidentiality is typically reduced in these cases. To continue, investor-state disputes very frequently involve state interests and legislative policies much more directly than many commercial disputes, which usually only feature indirect state involvement, if any state involvement at all. Investor-state arbitration is also quite removed from national courts and law, to the point that it could be called autonomous due to its unique legal regime. ${ }^{43}$ However, it should be noted that investors are still subject to the host state's laws, and many cases involve at least some references to its domestic law (typically labor law, environmental law or company law). ${ }^{44}$

Furthermore, in international commercial arbitration, both disputing parties are allowed to present claims against one another. Compare this to investor-state arbitration which is onesided, as the investor is permitted to assert claims against the host state, but the state is often not able to assert claims or counterclaims against the investor. This structure is a result of how the terms of most Bilateral Investment Treaties are formulated, which only mandate obligations for states, and not for investors (at least usually). However, in disputes arising under specific investment contracts (between the investor and the host state) or under a

\footnotetext{
${ }^{41}$ Christoph Schreuer, 'The Relevance of Public International Law in International Commercial Arbitration: Investment Disputes' 1 <https://www.univie.ac.at/intlaw/pdf/csunpublpaper 1.pdf> accessed 03 January 2019 
contract covered by an umbrella clause, states may be occasionally permitted to present counterclaims against an investor. ${ }^{45}$

Thus, it can be concluded that investment arbitration has a number of unique characteristics that sets it apart from the usual kind of international commercial arbitration. It has its own body of traditions, and patterns of behavior.

\subsection{Dispute between a contracting party and an investor}

After discussing the investor-state arbitration system in general terms, and comparing it to the standard model of international commercial arbitration, the time has come to discuss this system in the Energy Charter Treaty itself. One of the most fundamental features of the Energy Charter Treaty is the mandatory mechanism for dispute settlement between host States and foreign investors. ${ }^{46}$ Dispute settlement arises when host States breach their obligations under PART III of the Energy Charter Treaty (Investment Promotion and Protection). In the event of a dispute between a host state and an investor Article 26 provides a comprehensive procedure. First of all, it requires that the parties to the dispute try to solve their dispute in an amicable way. ${ }^{47}$ Thus, we can see that the policy of the Energy Charter Treaty is to settle disputes which arise between the parties by firstly encouraging them to go through amicable or peaceful settlement. ${ }^{48}$ If it is not possible, within three months from the date of initiation of such amicable settlement, ${ }^{49}$ the investor may choose from the following three possibilities:

(a) to [submit the dispute] to the courts or administrative tribunals of the Contracting Party to the dispute;

\footnotetext{
${ }^{45}$ A. Newcombe \& L. Paradell, Law and Practice of Investment Treaties: Standards of Treatment (2009) 64

${ }^{46}$ Christian Tietje, International Investment, Protection and Arbitration: Theoretical and Practical Perspectives (BWV Verlag, 2011) 27

${ }^{47}$ Energy Charter Treaty Article 26.2

${ }^{48}$ Graham Coop, Energy Dispute Resolution: Investment Protection, Transit and the Energy Charter Treaty (Juris Publishing, Inc., 2011) 1xiii

${ }^{49}$ Association for International Arbitration, Alternative Dispute Resolution in the Energy Sector (Maklu, 2009) 38
} 
(b) [submit the dispute] in accordance with any applicable, previously agreed dispute settlement procedure;

(c) [submit the dispute] in accordance with [Article 27].50

Here we should emphasize that only the investor party may submit the issue for the above mentioned resolution, the host State does not have the right to initiate arbitration.

This initial provision provides foreign investors and states a proper procedure in settling disputes. ${ }^{51}$ Parties may resolve their disputes in a variety of ways, including amicable settlement, negotiation, courts, or through arbitral tribunals. ${ }^{52}$ Further sections of Article 26 specify the characteristics that the arbitral tribunal will have. If the investor submits its claim using subparagraph 2(c), it will be submitted to either the "International Centre for Settlement of Investment Disputes (ICSID), a sole arbitrator or ad hoc arbitration established under the Arbitration Rules of the United Nations Commission on International Trade Law (UNCITRAL), or an arbitral proceeding under the Arbitration Institute of the Stockholm Chamber of Commerce." ${ }^{53}$ The disputes must be related to a breach of obligations listed in Part III of the Treaty. ${ }^{54}$ Hence, disputes are limited according to this article and no case hearing takes place if it is not related to the breach of obligations mentioned in part III of Energy Charter Treaty which contains provisions related to investment promotion and protection. According to these provisions, an investor should submit his claim to the host country judiciary, but if the investor does not receive a fair treatment, it has the right to choose one of the dispute settlement solutions mentioned in Article 27 of Energy Charter Treaty. ${ }^{55}$ However, an investor is not able to submit his claim to international arbi-

\footnotetext{
${ }^{50}$ Energy Charter Treaty Article 27

${ }^{51}$ R. Doak Bishop, James Crawford, William Michael Reisman, Foreign Investment Disputes: Cases, Materials, and Commentary (Kluwer Law International, 2005) 1010

${ }^{52}$ Angelos Dimopoulos, EU Foreign Investment Law (OUP Oxford, 2011) 330

${ }^{53}$ Epaminontas E. Triantafilou, Abby Cohen Smutny, Stephan W. Schill, Practising Virtue: Inside International Arbitration (Oxford University Press, 2015) 53

${ }^{54}$ Katia Yannaca-Small, Arbitration Under International Investment Agreements: A Guide to the Key Issues (Oxford University Press, 2010) 52

${ }^{55}$ Energy Charter Treaty Article 27
} 
tration or reconciliation if the claim was already submitted to a court or an administrative tribunal of the host country. ${ }^{56}$

Referring to Article 26.6, any award from tribunals should take into consideration the rules of Energy Charter Treaty, principles of international law and applicable rules. ${ }^{57}$ The resolution and arbitration award is binding upon the contracting parties, and so the host country should do necessary steps to enforce the award in its territory without any delay. ${ }^{58}$

\subsection{Dispute between contracting parties}

Article 27 of the Energy Charter Treaty deals with all disputes which may arise between contracting parties to Energy Charter Treaty, which are related to interpretation and application without additional agreement between contracting parties except those covered by Articles 29 and 5. ${ }^{59}$ Article 29 relates to trade in energy products between Energy Charter Treaty parties which are not parties of General Agreement on Tariffs and Trade (GATT) ${ }^{60}$. Article 5 deals with issues related to World Trade Organization (WTO) ${ }^{61}$.

As stated in Article 27 and above, contracting parties need to settle their disputes first through diplomatic or amicable way. ${ }^{62}$ If the dispute between contracting parties was not solved diplomatically or amicably during reasonable time, the parties to the dispute have the ability to resort to an $a d$ hoc arbitration tribunal, as provided by the treaty. ${ }^{63}$

\footnotetext{
${ }^{56}$ Martti Koskenniemi, International Law Aspects of the European Union (Martinus Nijhoff Publishers, 1998) 209

${ }^{57}$ Energy Charter Treaty Article 26.6

${ }^{58}$ Energy Charter Treaty Article 26.8

${ }^{59}$ Energy Charter Treaty Article 28

${ }^{60}$ Energy Charter Treaty Article 29

${ }^{61}$ Energy Charter Treaty Article 5

${ }^{62}$ Dimitry Kochenov, Elena Basheska, Good Neighbourliness in the European Legal Context; Studies in EU External Relations (BRILL, 2015) 373

${ }^{63}$ Energy Charter Treaty Article 27
} 
The process of ad hoc arbitration tribunal as reported by Energy Charter Treaty is the following: The claimant has to appoint its representative for the arbitration tribunal and inform the respondent in writing within 30 days from the date of submitting the claim to ad hoc arbitration. Following this, the respondent should appoint its representative to the arbitral tribunal within 60 days from the date of submitting the claim to ad hoc arbitration by the claimant. ${ }^{64}$ If the respondent denied appointing its representative for the ad hoc arbitration, the claimant should request the Secretary-general of the Permanent Court of the International Arbitration to do so. ${ }^{65}$ In case the Secretary-general denies appointing any representative for the Respondent, the Claimant requests First Secretary of the Office to appoint a representative. In case the First Secretary also denies appointing a representative for the Respondent, then in such situation the senior deputy will do this. ${ }^{66}$

Later, the representatives of both contracting parties must appoint a third party who will be the president of arbitration tribunal. ${ }^{67}$ If the contracting parties do not succeed to appoint the third party within 180 days from the date of submitting a claim to the ad hoc arbitration by the claimant, then the same rules are applied to appoint the third party as same were applied to appoint a representative for the Respondent. 68

If there is no agreement about the applicable and procedure law between contracting parties in advance, the arbitration tribunal applies rules of arbitration which is stated in the United Nations Commission on International Trade Law (UNCITRAL) convention. Nevertheless, the parties may depart from some of the rules or they accept a sole arbitrator or an ad hoc arbitration tribunal. The arbitration tribunals should take into consideration the principle of Energy Charter Treaty and international law and applicable law in any case. ${ }^{69}$

\footnotetext{
${ }^{64}$ Energy Charter Treaty Article 27.3

${ }^{65}$ Filip Černý, Naděžda Rozehnalova, Alexander J. Bělohlávek, Czech Yearbook of International Law - The Role of Governmental and Non-governmental Organizations in the 21st Century - 2014 (Juris Publishing, Inc., 2014) 123

${ }^{66}$ Energy Charter Treaty Article 27.3

${ }^{67}$ Cyril Chern, The Law of Construction Disputes; Construction Practice Series (CRC Press, 2016) 278

${ }^{68}$ Mustafa Erkan, International Energy Investment Law: Stability Through Contractual Clauses (Kluwer Law International, 2011) 345

${ }^{69}$ Catherine Barnard, Okeoghene Odudu, Cambridge Yearbook of European Legal Studies, 2009-2010 (Bloomsbury Publishing, 2010) 438
} 
The arbitration tribunals' expenses are divided equally between contracting parties. It is also acceptable if the arbitration tribunal asks a party to pay more than other party. ${ }^{70}$

${ }^{70}$ Energy Charter Treaty Article 27.3 


\section{The Energy Charter Treaty from the perspective of energy export- ing countries}

In this chapter, I will attempt to expound on the various general problems and issues related to the Energy Charter Treaty. In particular, my methodology will be the following: I will first write about the Energy Charter Treaty from the perspective of energy-exporting countries, and discuss the various advantages and disadvantages of being a contracting party of the Energy Charter Treaty, with special attention paid to countries that are net energy-exporters. Through this, I will focus on the nature of the Energy Charter Treaty.

Let me refresh the reader's memories about the origins of the Energy Charter Treaty. As discussed in Chapter 1, the original idea of the Energy Charter Treaty is fundamentally "western" in thought and concept, a result of the collapse of the Soviet Union and the new economic, political and diplomatic opportunities, the cessation of the eastern bloc (including Asian countries previously under the influence of the Soviet Union) presented to Western Europe. While it was mentioned that the original concept for the Energy Charter Treaty and its precursor proposals was one of idealism, and an attempt at redefining the economic and diplomatic relations between Western and Eastern Europe, by creating a new, mutual symbiosis of energy export and import through foreign investments under the auspices of a multilateral treaty guaranteeing protections to the energy industry, it was ultimately also a result of pragmatism and economic necessity.

This pragmatism is evidenced by how the countries of Western Europe were net energy importers and needed energy resources to fuel and expand their advanced industries and economies. Such a demand was seen as easily fulfilled by the poorly developed, but rich in energy countries of the East. However, a desire for this also necessitated the formation of a multilateral energy treaty, due to how technical expertise, infrastructure and funds were absent in the countries that were to be incorporated into this new multinational economic regime. Thus, foreign investment, protected by the treaty, was seen as the correct way to solve these difficulties.

Logic dictates that this chapter should further be separated in two: first, it is prudent to discuss the Energy Charter Treaty from energy exporters that are contracting parties of it, and then expound on the perspective of energy exporters outside of the Treaty. 


\subsection{Energy Charter Treaty from the perspective of net energy exporting contracting parties}

As mentioned previously in the dissertation, the two largest energy exporters who are contracting parties of the Energy Charter Treaty are Kazakhstan and Norway, and therefore, these two countries should be the focus of this part as well, alongside Turkmenistan and the Netherlands, another two significant energy exporting countries who are full contracting parties of the Energy Charter Treaty.

Let me start from the perspective of Kazakhstan. As mentioned at the very beginning of the dissertation, Kazakhstan exports roughly 1.355 million oil barrels per day and is ranked $12^{\text {th }}$ in oil exports. ${ }^{71}$ By becoming a full contracting party of the Energy Charter Treaty, Kazakhstan has a greater ability to attract foreign investment, but by contrast, it also forsake some of its control over the energy sector, and lost its sovereign immunity to suits (this will be discussed in more detail shortly). As a country without access to seaports, it can also be concluded that the Energy Charter Treaty is important to Kazakhstan due to it potentially ensuring a more stable transit possibility. However, the issues between Russia and the Energy Charter Treaty (as discussed in the beginning of the dissertation) might have weakened this aspect of the Treaty from Kazakhstan's perspective. Article 18 is also of primary importance to Kazakhstan, since it ensures state sovereignty over natural resources, which is of course extremely important to an energy exporting party of the Treaty. However, it can be argued that much of the attraction that the Energy Charter Treaty held for Kazakhstan was lost after the Russian "withdrawal" from the Treaty (as discussed in Chapter 1), especially in relation to the above-mentioned transit issues.

Despite the still somewhat beneficial situation detailed above, Kazakhstan also had its troubles with the Energy Charter Treaty, as described in the case law section of the dissertation. The "Liman Caspian Oil BV "LCO" and NCL Dutch Investment BV "NCL" against the Republic of Kazakhstan" was the case in question. However, Kazakhstan emerged mostly unscathed from the case, as although the claimants won over the question of juris-

\footnotetext{
${ }^{71}$ United States. Office of Energy Markets and End Use, Short term energy outlook: Quarterly projections (The Office, 1995) 25
} 
diction, Kazakhstan won over the merits of the case, and thus the cost of the proceedings was evenly split between the claimants and the respondent.

After Kazakhstan, let me briefly discuss the situation of Norway. As mentioned in Chapter 1, Norway exports approximately 1.68 million oil barrels per day and is ranked $14^{\text {th }}$ in exports. ${ }^{72}$ Norway is a very different country, when compared to Kazakhstan. Its easy access to the sea due to its long coastline, and its relative wealth and prosperity naturally ensured that the country was less reliant on foreign investments to develop its infrastructure and energy sector, than it is the case with Kazakhstan. Conversely, the transit clauses of the Energy Charter Treaty can be concluded as somewhat less important to Norway, than it is to a landlocked country like Kazakhstan. The exception to this general observation being the North Sea gas pipelines that Norway uses to export its not-insignificant natural gas reserves, which require transit through the offshore territories of other North Sea countries, and thus a strong treaty-based transit regime can be considered in Norway's best interests. Therefore, it can be argued that Norway still has a vested interest in Article 18, similar to Kazakhstan. At the same time, as an energy exporter, preserving its sovereignty over its natural resources is still important to Norway. Furthermore, it is worth noting that Norway was strongly suspicious of the inclusion of investor-state dispute settlement mechanisms (as discussed in Chapter 1), and therefore it can be concluded that its relationship to the Energy Charter Treaty is less universally cooperative than one might think.

Let me move on to Turkmenistan; an associate state of the Commonwealth of Independent Nations, and ranked $9^{\text {th }}$ in natural gas exports. ${ }^{73}$ Turkmenistan has very significant reserves of natural gas; however it is hampered by lack of infrastructure, technological expertise and its landlocked status, despite decades-long government efforts to address this issue. Similarly to Kazakhstan, the transit clauses are of unparalleled importance to Turkmenistan in its relationship with the Energy Charter Treaty. We can also include the protection the Energy Charter Treaty provides for long-term energy investments as another important part of the Treaty for the country. ${ }^{74}$

\footnotetext{
${ }^{72}$ Energy Department, Annual Energy Review 2008 (Government Printing Office, 2009) 315

73،CIA World Factbook'< https://www.cia.gov/library/publications/the-world-factbook/rankorder/ 2251rank.html> accessed 10 November 2017

74'Energy Charter'<https://energycharter.org/media/news/article/the-energy-charter-providing-security-of-transit-for-turkmenistan/> accessed 25 February 2018
} 
This can be once again explained by both the low level of technological development of the former Soviet republic, and the fact that Turkmenistan can be viewed as a rather repressive country, where the rule of law can be considered very uncertain. This means that in order to attract foreign investment and ensure the safe extraction and transit of its energy exports, Turkmenistan needs the provisions of a multilateral treaty such as the Energy Charter Treaty.

Finally, it is imperative to mention the Netherlands, which is ranked $6^{\text {th }}$ in natural gas exports. ${ }^{75}$ As extensively detailed in Chapter 1 , the Netherlands can be considered the chief mastermind behind the original idea of tying the West and the East in economic cooperation, which laid the groundwork for the appearance of the Energy Charter Treaty. This means that despite its status as an energy exporter, the Netherlands hews much closer in interests to the western energy importer countries, for which the Energy Charter Treaty was ultimately designed for. This is exemplified by the several energy cases involving Dutch companies (such as Azpetrol International Holdings B.V., Azpetrol Group B.V., Azpetrol Oil Services Group B.V. versus the Republic of Azerbaijan, or Khan Resources Incorporated Khan Resources B.V, CAUC Holding Company Ltd. against Republic of Mongolia and MonAtom LLC, or Isolux Netherlands, BV v. Kingdom of Spain), as detailed in Chapter 4. These examples clearly show that the Netherlands behaves much more like an energy importer country under the Energy Charter Treaty, than as a typical energy exporter country. In conclusion, we can say that for the energy exporter countries in the Energy Charter Treaty, there is a number of common issues and stances, specifically in relation to sovereignty over natural resources and questions of transit. For these countries, these provisions as well as the attraction of foreign investments outweigh the potential loss of control caused by being in the multilateral treaty.

\subsection{Perspectives on the Energy Charter Treaty for non-contracting ener- gy exporters}

In this section, I will detail the situation of select energy exporting countries, how they view the Energy Charter Treaty, and (if possible) whether being in the Treaty would be ad-

\footnotetext{
${ }^{75}$ 'CIA World Factbook'<https:/www.cia.gov/library/publications/the-world-factbook/rankorder/ 2251rank.html> accessed 10 November 2017
} 
vantageous for them or not. In particular, I am going to cover the following countries: Russia, Saudi Arabia, Iran, Algeria and finally Iraq. These countries were selected as energy exporters that are not full contracting parties of the Treaty, and examples of non-Western countries, which dominated the Treaty talks during its conceptualization.

First to be discussed is Russia. As mentioned previously in the dissertation, the Russian Federation has access to extensive natural resources, including energy resources, especially when it comes to natural gas, where it is ranked global $1^{\text {st }}$ in exports. ${ }^{76}$ In Chapter 1 , Russia's position on the Energy Charter Treaty was extensively discussed. Despite signing the Treaty, and later provisionally applying it, a breakdown in the process eventually resulted in Russia withdrawing from the ratification of the Energy Charter Treaty in 2009.

As explained in Chapter 1, this event was the result of several different factors. One was the issue of transit. A recurring theme among the energy exporter countries as we have seen, especially for those states which supply natural gas through pipelines, is the need for safe transit of their exports and the prevention of transit theft. Another factor detailed previously was the animosity between the European Union and Russia, as Russia perceived the Energy Charter Treaty as somewhat unfair, because the European Union was able to bypass many obligations in the multilateral treaty that were still applied to the Russian Federation. As described in Chapter 1, all these culminated in the withdrawal of Russia from the Energy Charter Treaty.

We can also conclude that the withdrawal of Russia must have had a negative impact on other eastern contracting parties of the Energy Charter Treaty, in particular countries like Kazakhstan and Turkmenistan. As mentioned earlier in the chapter, both countries rely on transit through the lands of the Russian Federation, in order to export their energy to the western energy importer contracting states. Without the safety and surety provided by the multilateral Energy Charter Treaty, the status of these transit lines is much more uncertain. Furthermore, the Russian withdrawal from the Energy Charter Treaty signified an important breakdown in the original concept of the Treaty. Uniting the West and the East in economic symbiosis through the energy sector has become much more far-fetched without the presence of the Russian Federation, arguably the most significant eastern energy exporting country under the consideration of the Energy Charter Treaty.

\footnotetext{
76'CIA World Factbook' < https://www.cia.gov/library/publications/the-world-factbook/rankorder/ 2251rank.html> accessed 24 February 2018
} 
The second country to be briefly examined is Saudi Arabia. Situated on the Arabian Peninsula, Saudi Arabia is a top oil exporter, ranking $1^{\text {st }}$ in crude oil export worldwide. ${ }^{77}$ It is also an observer of the Energy Charter Conference, but not a contracting party of the Energy Charter Treaty.

The situation of Saudi Arabia is somewhat unique, as it maintains a strong relationship with the United States of America, while also retaining a strong grip on its domestic energy production, oil to be specific. The country has a strong position in the oil industry, which it parlays into diplomatic and political influence. This explains while the country does not seem particularly interested in becoming a contracting party of the Energy Charter Treaty. Due to a relatively high level of domestic capital, especially when it is compared to other energy exporters in the region, Saudi Arabia is less reliant on foreign investors and capital to develop its economy. And as it was already discussed, attraction of foreign investment seems to be the primary reason why an energy exporting country would seek to join the Energy Charter Treaty. Furthermore, Saudi Arabia also has little issues with ensuring its sovereignty over its natural resources, hence this aspect of the Energy Charter Treaty is also far less attractive to them than it is compared to other energy exporters.

The third country to be covered is Iran who another important energy exporter, ranking $12^{\text {th }}$ in crude oil exports. ${ }^{78}$ While this is lower than some of the other countries covered here, Iran is still worthwhile to mention. This is because of several different reasons, some of them already touched earlier in this dissertation. In particular, Iran has already came up in relation with the various issues surrounding its expropriation of foreign investments in the Seventies that led to a serious dispute between it and the United States of America. The dissertation has already briefly covered these events, and so repeating them here would be superfluous. Instead, it is more sensible to refer to the conclusions we can draw from such expropriations. We can conclude that this situation, combined with the relative isolation of Iran on the world-stage, has significantly lowered the attraction of Iran as host country for foreign investors in the energy sector. Thus, Iran is not part of the Energy Charter Treaty due to this semi-isolationist position and tense relation with most western countries. How-

\footnotetext{
77'CIA World Factbook'<https://www.cia.gov/library/publications/the-world-factbook/rankorder/ 2242rank.html $>$ accessed 25 February 2018

${ }^{78}$ 'CIA World Factbook' < https://www.cia.gov/library/publications/the-world-factbook/rankorder/ 2242rank.html> accessed 24 February 2018
} 
ever, if Iran seeks to further integrate into the global economic order, and advance its energy exports, it seems reasonable that it would need to make itself more attractive for foreign investors, as they lack the capital and connections that countries such as the before mentioned Saudi Arabia has, meaning they cannot completely rely on their own internal resources to advance. A good way to accomplish this would be to enter into the Energy Charter Treaty, which would expand Iran's opportunities to develop its energy sector, attract foreign investors and integrate more fully into the global economy.

The ultimate country to be briefly discussed is Algeria. Algeria is ranked $8^{\text {th }}$ in natural gas exports. ${ }^{79}$ It is an observer of the Energy Charter Conference, but much like Saudi Arabia, it is not a contracting party of the Energy Charter Treaty. Algeria's position is a unique one due to its close geographical proximity to Europe and serving as a major supplier of energy to energy importing countries in Europe. However, it has recently started having issues with its gas supplies, due to growing domestic and European demand for natural gas. Before recent times, Algeria was considered by foreign investors a difficult country to work with in the energy sector. However, after oil prices collapsed in 2014 (as Algeria also exports crude oil), the country was forced by its circumstances to become more flexible and increase cooperation with foreign investors to maintain its finances. ${ }^{80}$ This presents an interesting question. Since Algeria has already changed its approach towards foreign investments, wouldn't it be more sensible for Algeria to join the Energy Charter Treaty? Algeria is definitely in need of extra capital to meet fresh demands and expand its infrastructure, while the Energy Charter Treaty not only provides all of that, it also provides solutions for transit issues and questions of sovereignty over natural resources.

In conclusion, we can see that the Energy Charter Treaty does have significant influence on energy exporters, and many energy exporting countries are either contracting parties, or would have reason to become one. After this brief horizontal discussion, I can now move on to the specific issues.

\footnotetext{
79'CIA World Factbook'< https://www.cia.gov/library/publications/the-world-factbook/rankorder/ 2251rank.html> accessed 25 February 2018

${ }^{80}$ 'Economic Times'<https://energy.economictimes.indiatimes.com/news/oil-and-gas/algeria-natural-gas-exports-to-reach-54-bcm-in-2017-sonatrach-chief/59801779> accessed 27 February 2018
} 


\section{Promotion, protection and treatment of investments and the issues of expropriation and compensation}

Generally, economic theory defines investment as diversification of money in order to get income or profit from it. Therefore, it can be said that with investing our money, we sacrifice some of our current interest in order to get a greater future profit. This is a risk; as the investor can never be quite sure about predicted profit in the future from the investment. ${ }^{81}$ This future profit depends on many factors, and some of them are outside an investors' control. It is also important for an investor to predict the time of the actual future profit. So, if the investor manages a good time schedule and there is no delay in terms of the time of future profit, the level of profit will be significant. However, if there is any delay, the investor will be affected by it.

Foreign investment has exploded in importance since the last century, and it has become one of the most important crutches of the economy of the host states, especially for developing countries. In the past, foreign investment was not very welcome in most states, but recently has become extremely desirable for purposes of economic growth. It can be said that friendly political relations among states resulted in increased investments, and that such an expansion of investments decreased the role of borders in the world. ${ }^{82}$

Thus, states have opened their local markets for foreign investments, which bring money, technology, expertise in production and management, capability in export and import, sale, distribution and so on. ${ }^{83}$

Historically, foreign investors had certain fears about investing in developing countries as there was a possibility of expropriation, nationalization, war and other risks. However, there were already some kind of guarantees for foreign investors (like investment protection laws, guarantees in bilateral and multilateral investment protection treaties), but those guarantees were not always enough to protect them from the above-mentioned risks. ${ }^{84}$

\footnotetext{
${ }^{81}$ 'Business Dictionary'<http://www.businessdictionary.com/definition/investment.html> accessed 2 May 2017

${ }^{82}$ Petya Koeva Brooks, 'Time-to-Build and Convex Adjustment Costs' (2001) International Monetary Fund, 3. $<$ https://www.imf.org/external/pubs/ft/wp/2001/wp0109.pdf > accessed 2 May 2017

${ }^{83}$ OECD, OECD Investment Policy Perspectives 2008 (OECD Publishing, 2009) 21

${ }^{84}$ Traore-Tsagao, 'La garantie des investissements étrangers en Afrique et droit international' (DPhil thesis, A.N.R.T, Université de Lille III, 2001) 24
} 
Therefore, investors sometimes went beyond, and demanded to share with the host state the administration and observation of the investment projects. This was the main reason that allowed foreign investors to get the right of ownership over their investment in host countries where this was in question (For example China and other socialist countries). ${ }^{85}$ This sometimes reduced the political and economic independence of the host country to an extent. 86

For example, Iraq has started to do its best to attract foreign investors to invest in the country. It has improved its legislation in the field of finances, taxes, customs, procedure, etc. It strengthened its investment protection laws and put a higher emphasis on ensuring due process of law. However, it was not enough, as those guarantees only opened the gates for foreign investors theoretically. In my opinion, Iraq needs to do more in practice to achieve its goal of attracting more investments. ${ }^{87}$

Currently, the ownership of investments for foreign investors in a territory of host countries has become very important. This ambition has faced many challenges. Ownership gives foreign investors a strong position on the territories of the host state. ${ }^{88}$ However, the risk of expropriation or nationalization still remains.

In general, there is a principle to protect private property and foreign investors as owners of the investment project in particular. ${ }^{89}$ The majority of constitutions nowadays mention the principle of protecting private property, so in this case, the property of foreign investors is protected by the constitution too. However, this does not exclude a state from exercising its sovereignty or its right to take and expropriate property. ${ }^{90}$

As an example of the above, in Resolutions 523 (VI) of January 12, 1952, and 626 (VII) of December 21, 1952, the General Assembly of the United Nations declared that every state

\footnotetext{
${ }^{85}$ Benjamin F. Bobo, Rich Country and Poor Country; The Multinational as Change Agent (Greenwood Publishing Group, 2005) 80

${ }^{86}$ Encyclopedia of Alternative Investments (CRC Press, 2008) 2

${ }^{87}$ IBP, Inc, Iraq Country Study Guide Volume 1 Strategic Information and Developments

World Business Information Catalog (International Business Publications, Inc. 2012) 188

${ }^{88}$ Douglas P. Woodward, Douglas William Nigh, Foreign Ownership and the Consequences of Direct Investment in the United states: Beyond Us and Them (Greenwood Publishing Group, 1998) 324

${ }^{89}$ Young Back Choi, Perspectives on Korean Unification and Economic Integration (Edward Elgar Publishing, 2001) 110

${ }^{90}$ Ibrahim F. I. Shihata, Legal Treatment of Foreign Investment: "The World Bank Guidelines" International Studies in Human Rights (Martinus Nijhoff Publishers, 1993) 290
} 
has the right to exploit its national resources. These resolutions were established, based on public, security and national interest considerations. These United Nations' resolutions also recognized the right of the state to expropriate. This Resolution prefaced a social and economic policy of the sixties and seventies, during which many former colonies declared their independence. The Resolution was released to remove the international responsibility of these new states when they expropriated foreign investments without affecting the right of foreign investors to ask for appropriate compensation. ${ }^{91}$ However, their position later changed, as the newly independent countries needed capital beyond what expropriation allowed them to seize. This meant that they had to attract foreign investors, and thus their position on expropriation significantly softened. Meanwhile, developed countries desired to convert their various constitutional rights relating to property into international standards. This led to the birth of the bilateral investment treaties (BITs), starting from 1959. ${ }^{92}$

\subsection{Investment and Investor}

Investment (foreign) is the first concept that needs to be discussed in detail. The International Centre for Settlement of Investment Disputes Convention provides a somewhat vague definition for the term 'investment'. For the purposes of this research, only the ICSID Convention was given a major focus as this is the most notable treaty from the research's point of view, besides the Energy Charter Treaty itself.

Some scholars explained the term investment as assets such as property, rights, or interests of any kind..$^{93}$ The broad concept of what constitutes foreign investment does not limit investment to physical investments and properties over which property right can be given, but it covers all manifestations of direct or indirect control over investment elements that have economic value; such as, various service contracts. This means that there is a vast field of protection which is related to foreign investor properties that include immovable

\footnotetext{
${ }^{91}$ Encyclopedia of Disputes Installment $10\left(1^{\text {st }}\right.$ edn, Elsevier, 2014) 307

${ }^{92}$ Nagy, Csongor István, 'Free Trade, Public Interest and Reality: New Generation Free Trade Agreements and National Regulatory Sovereignty’ (2018) vol. IX Czech Yearbook of International Law 206

${ }^{93}$ OECD, International Investment Law: Understanding Concepts and Tracking Innovations A Companion Volume to International Investment Perspectives: A Companion Volume to International Investment Perspectives (OECD Publishing, 2008) 87
} 
and movable properties, as well as economic activities of the foreign investor. Most of the international bilateral treaties have used the broad definition of investment, which refers to "every kind of investment" or "every kind of asset". 94

In the case of Saipam S.P.A v Bangladesh ${ }^{95}$, the Court relied on the broad definition of investment as 'any kind of property' rather than having to determine specifically what category of asset it is. As this broadens the definition of investment, it is generally the favored approach by capital exporting countries, as it protects more of the various kinds of assets that may be invested in a host state. On the other hand, the host state would prefer a narrower definition of investment, so that they can better predict the impact that their actions (policy or otherwise) would have on foreign investors. ${ }^{96}$

In determining whether or not an arbitral tribunal has jurisdiction to hear a dispute, the tribunals have used different approaches to decide whether or not there is an investment. This is due to the lack of clarity found in Article 25(1) of the ICSID Convention, which merely states that any dispute must arise out of an investment.

The first approach in determining an investment is identifying the characteristics of investments as discussed earlier. The criteria for characteristics of an investment have been developed by C.H. Schreuer, which is that there must be "a certain duration, a certain regularity of profit and return, the assumption of risk, substantial commitment, and the operation's significance for the development of the host state". ${ }^{97}$

The second approach references the instrument containing consent between the parties; which means the contract between the host state and the foreign investor should be examined. These agreements generally identify what constitutes investment. This is a more pragmatic and flexible approach that allows parties themselves to determine the scope of the definition of the term 'investment'. ${ }^{98}$

\footnotetext{
${ }^{94}$ Thomas Pollan, Legal Framework for the Admission of FDI (Eleven International Publishing, 2006) 32.

95 Decision on Jurisdiction and Recommendation on Provisional Measures, March 21, 2007, Saipem S.p.A. v. The People's Republic of Bangladesh, ICSID Case No. ARB/05/07

${ }^{96} \mathrm{M}$. Malik, 'Recent Developments in the Definition of Investment in International Investment Agreements, International Institute for Sustainable Development' (2008) 6-7. $<$ http://www.iisd.org/library/definition-investment-international-investment-agreements $>$ accessed 14 June 2017

${ }^{97}$ Berk Demirkol, 'The Notion of 'Investment' in International Investment Law' (2015) 41 Turkish Commercial Law Review 42. <https://ssrn.com/abstract=2579247> accessed 16 June 2017

98ibid 43
} 
this third approach is determining whether consecutive criteria apply at the same time; This means more strictly defined elements must be present otherwise it would fail to constitute an investment. According to Demirkol, there are 3 sub-categories of approaches used by Arbitral Tribunals.

The first sub-category consists of tribunals that apply the Salini test. The Salini test establishes four elements of investment: 1) contributions, 2) particular duration of contract, 3) participation in the investment must involve risk, and 4) must have contributed to the development of the host state. ${ }^{99}$ The investment will be tested, to see if they have each of these four elements before it is considered an investment under the ICSID Convention. ${ }^{100}$ However, it should be noted that this approach to the Salini test is far from universal, in some cases, such as the Philip Morris case ${ }^{101}$, the arbitral tribunal argued for a different approach to the test, in that it considered the four elements to be merely common features of an investment, and the presence of all four could not be construed as a jurisdictional requirement. The presence of only some of these common features is enough to establish jurisdiction, and to consider the investment in question an investment under the ICSID Convention.

The second subcategory is the requirement of positive and significant contribution to the host state. The justification for this, being a salient criteria, is that the Preamble to the ICSID Convention states that economic development through private international investment is the principle focus that ICSID attempts to facilitate. The MHS Tribunal ${ }^{102}$ required significant contribution to be made to the host state's economy. Similarly, the Patrick Mitchell ${ }^{103}$ tribunal annulled the award due to the fact that the party's law firm did not prove that his party had contributed significantly to the host state's economy. However, there are other tribunals that did not require significant contribution to the host state's

\footnotetext{
${ }^{99}$ Salini Construttori S.p.A and Italstrade S.p.A. v Kingdom of Morocco, ICSID Case No. ARB/00/4, Decision on Jurisdiction (23 June 2001) para 52

${ }^{100}$ ibid 46

${ }^{101}$ Philip Morris Brands Sàrl, Philip Morris Products S.A. and Abal Hermanos S.A. v. Oriental Republic of Uruguay, ICSID Case No. ARB/10/7

${ }^{102}$ Malaysian Historical Salvors (MHS) v The Government of Malaysia, ICSID Case No. ARB/05/10, Award on Jurisdiction (17 May 2007) para 123

103Patrick Mitchell v The Democratic Republic of Congo, ICSID Case No. ARB/99/7, Decision on the Application for Annulment (01 November 2006) paras 29 - 30 and 33
} 
economy, as economic development is the goal of the ICSID, but not a constitutive element. ${ }^{104}$

Another sub-category of the approach is the so-called Phoenix Test; this requirement adds that "protected" investments must be legal and made in good faith. This test therefore includes the four requirements of the Salini test, but also adds two additional requirements, making a total of six constitutive elements. The problem with this approach is that the legality or bona fide status of an investment is only discussed in the merits phase of the Tribunal process. Therefore, for the initial question on whether there is an 'investment' or not, the Tribunal only has to look to see if an 'investment' exists, regardless of its legality or bona fide status.

Lastly, the ordinary meaning approach looks at the investment from the economic perspective. If there is some effort in connection with some asset to create some kind of monetary benefit, then it could ordinarily mean an investment, rather than based on an artificially created definition. The constitutive elements would still resemble those of the Salini test, and this is why this approach is the most preferred. 105

In conclusion, there are different approaches used by Arbitral Tribunals in determining whether they have jurisdiction to hear a dispute. Some tribunals favor a broader approach, keeping the spirit of "any type of property", while some tribunals went into more detail. The fact that the ICSID Convention is silent on the actual definition of investment has caused some obscurity as to its definition, but nevertheless Tribunals have looked into the nature and characteristics of the investments to ensure it meets the right criteria of an investment.

Finally, it would be prudent to talk about IIAs as most IIAs including Bilateral Investment Treaties (BITs) formulate the definition of 'investment' by using a broad phrase such as "every kind of asset" or "any kind of asset", and then is narrowed down to particular classes of assets. For example, the German Model Treaty uses this broad terminology, and then

\footnotetext{
${ }^{104}$ Berk Demirkol, 'The Notion of 'Investment' in International Investment Law' (2015) 41 Turkish Commercial Law Review 47. <https://ssrn.com/abstract=2579247> accessed 16 June 201 
lists 5 categories of assets, including property, shares, claims, intellectual property, and business concessions. ${ }^{106}$

The structure of this definition is found in other European model treaties, and has been used for many decades in European IIAs. The U.S. has also finished the US Model BIT (2004), which goes into even greater detail for more clarity. This Model BIT, along with the Norwegian Model, has included a qualification that the 'investment' must have 'the characteristics of an investment'. This is clearly a limiting phrase intended to add greater detail to the definition of an investment. In the Norwegian Model, it is phrased as: "In order to qualify as an investment under this Agreement, an asset must have the characteristics of an investment, such as the commitment of capital or other resources, the expectation of gain or profit, or the assumption of risk." 107

The Energy Charter Treaty provisions should be discussed as Part III of the Energy Charter Treaty contains the investment protection provisions. In the Energy Charter Treaty, the term investment has a broad meaning, and is defined in Article 1(6) as encompassing "every kind of asset, owned or controlled directly or indirectly by an Investor."108 This includes tangible and intangible assets, movable and immovable property rights, a company or business, as well as shares, stocks, bonds, claims to performance, intellectual property and rights conferred to by law or contract. The question of what constitutes an investment under the Energy Charter Treaty cropped up in the case of Libananco v. Turkey. In this case, Turkey (the Respondent), tried to claim that Libananco Holdings (the Claimant) was not an investor, nor did it make an investment under the Energy Charter Treaty. This forced the Tribunal to interpret the Energy Charter Treaty's definition of investment. Another case was Petrobart v. Kyrgyzstan, where the Respondent tried to dispute the definition of investment using its own domestic foreign law, despite the fact that the Claimant alleged breaches under the Energy Charter Treaty. This naturally meant that the definition of in-

\footnotetext{
106، German Model Treaty Concerning the Reciprocal Encouragement and Protection of Investment issued by the Federal Ministry of Economics and Labour' (2005) Article $1<$ http://www.fes-globalization.org/dog_publications/Appendix\%201\%20German\%20Model\%20Treaty.pdf> accessed 16 June 2017

${ }^{107}$ 'Norwegian Model for for promotion and protection of investments' (draft version 191207) Article $2<$ https:// www.italaw.com/sites/default/files/archive/ita1031.pdf $>$ accessed 16 June 2017

${ }^{108}$ James Crawford \& Karen Lee \& Elihu Lauterpacht, Reports of Cases Decided Under the Convention on the Settlement of Investment Disputes Between states and Nationals of Other states 1965, Thirteen version of ICSID Reports (Cambridge University Press, 2008) 296
} 
vestment in the Energy Charter Treaty took precedence over the definition found in domestic law.

Finally, the term investor in the Energy Charter Treaty also merits some attention. The definition found in the Energy Charter Treaty is that the investor (with respect to a contracting party) is a natural person having the citizenship or nationality of or who is permanently residing in that contracting party in accordance with its applicable law or a company. It can also be (with respect to a "third state") a natural person, company, or other organization which fulfils, mutatis mutandis, the conditions specified in the previous sentence for a contracting party. ${ }^{109}$

\subsection{Expropriation}

In general, expropriation is a social, economic and political phenomenon. During the last century it was closely tied to the concept of colonialism but today it is more tied to regulatory power of the state. When colonial countries got their full independence, their first action was to expropriate the properties of the monopolistic foreign companies that were supported by the old colonialist regime. ${ }^{110}$

This caused foreign investors to desire security for their investments. Foreign investors take major risks when investing in a country outside of their domicile. As mentioned above, one of the biggest risks these investors take is the possibility that the host state's government expropriates or nationalizes their assets, thus depriving them of their investment. A method of protection is the national investment protection laws of the investment recipient country. However, the problem with these laws is that they can be changed unilaterally by the host state. Thus, international protective instruments provide better guarantee for investors. Such international instruments can be bilateral or multilateral treaties or the above mentioned international agreements between the investor and the host state. ${ }^{111}$ Therefore, foreign investors use these treaties to restrict the host state's ability to expropriate (and of course, the host state voluntarily gives up its sovereignty in the specific field).

\footnotetext{
${ }^{109}$ Energy Charter Treaty Article 1 (7)

${ }^{110}$ Vincent B Khapoya, The African Experience (Routledge, 2015) 125

${ }^{111}$ Urban Rusnak, Expropriaton Regime under the Energy Charter Treaty (Energy Charter Secretariat, 2012) 8
} 
Furthermore, distinction should be made between direct and indirect expropriation. Direct expropriation occurs when the government takes or interferes with the property of a foreign investor, for example in the transfer of title, seizure of assets, or expulsion from the state. Throughout history, this has typically occurred when countries decided to nationalize industries from the foreign investor, in favor of the government or a government-linked 3rd party.

Indirect expropriation is more subjective as it can occur when measures taken by the host state leading to the foreign investor's property to lose significantly in value, or even deprivation of full management, use, or control of their own assets. ${ }^{112}$ In the OECD's Working Paper on Indirect Expropriation and the Right to Regulate in International Investment Law, three criteria were formulated to determine indirect expropriation: 1. the degree of interference with the property right, 2 . the character of governmental measures, i.e. the purpose and the context of the governmental measure, and 3. the interference of the measure with reasonable and investment-backed expectations. ${ }^{113}$ The degree of interference with the property right is the starting point to assess the impact of a government action, and determine whether it meets the threshold of indirect expropriation. This requires the claimant to show that although they still have the legal title to their property, the rights to use their property have to be eroded as a result of the interference by the government.

Regarding indirect expropriation, there is a case that bears some mention. This was the Le Chèque Déjeuner v. Hungary case. This case was notably not based on the Energy Charter Treaty, and thus would have little relation to the dissertation on the surface, being centered around vouchers and having the legal basis of the France-Hungary Bilateral Investment Treaty. However, the tribunal made some interesting observations regarding expropriation. In particular, the tribunal stated that "[i]n order to constitute an indirect expropriation, measures must interfere with property rights to such an extent that these rights are "rendered so useless that they must be deemed to have been expropriated" such that the measures must effectively destroy the economic benefit of the investment, resulting in the "neutralization, radical deprivation, irretrievable loss, inability to use, enjoy or dispose

\footnotetext{
$112_{\text {ibid }} 9$

${ }^{113}$ ibid 34
} 
of the property" and/or "that the property can no longer be put to reasonable use or makes any form of exploitation of the property disappear." 114

\subsubsection{Conditions of Lawful Expropriation under International Law}

After the general introduction of the concept of expropriation, let me move onto what conditions are necessary for expropriation that is in accordance with international law.

Expropriation is legitimate, but only if it is in the public's interest, non-discriminatory, ${ }^{115}$ follows due process, and includes the payment of prompt, adequate, and effective compensation. ${ }^{116}$ Any expropriation, direct or indirect, that does not meet these requirements would constitute illegal expropriation under the Energy Charter Treaty, as well as customary international law. ${ }^{117}$

The character of governmental measures needs to be identified and contextualized to determine whether the host state's actions were justified, for example if it was aimed at protecting public interest. The uncertainty of this criteria is that if a government passes a regulation that is in the public interest, but which causes a foreign investor to lose significant value of his property (i.e. if a mine owner can no longer operate his mine because the substance was banned for extraction in the host state), then the question arises as to whether the investor is owed compensation. ${ }^{118}$

This difficulty in distinguishing a legitimate regulatory measure from an indirect expropriation can be seen in contrasting case, since compensation will occur regardless of

\footnotetext{
${ }^{114}$ ICSID Case No. ARB/13/35, Award para 322

${ }^{115}$ Leilla Choukroune, Judging the state in International Trade and Investment Law: Sovereignty Modern, the Law and the Economics; International Law and the Global South (Springer, 2016) 138

${ }^{116} \mathrm{M}$. Sornarajah, The International Law on Foreign Investment (Cambridge University Press, 2010) 414, See also Zoltan Víg, Requirements of lawful taking of foreign property in international law (Iurisperitus Kiado, Szeged, 2016)

${ }^{117}$ Anna G. Micara \& Angela Lupone \& José Caiado, International Economic Law: Contemporary Issues (Springer, 2016) 220

118 Services de l'information et des relations culturelles (Belgium), Memo from Belgium (University of Pennsylvania, 2009) 29
} 
how the action is classified. This is shown in the case of Santa Elena, where the ICSID Tribunal held that: "Expropriatory environmental measures - no matter how laudable and beneficial to society as a whole - are in this respect, similar to any other expropriatory measures that a state may take in order to implement its policies: where property is expropriated, even for environmental purposes, whether domestic or international, the state's obligation to pay compensation remains." 119

This means that a government's actions, no matter how noble or beneficial to the public, will still require the government to pay compensation if any kind of indirect expropriation occurs as a result of the action. On the other hand, in the case of Methanex, the Tribunal decided that: “ ... as a matter of general international law, a non-discriminatory regulation for a public purpose, which is enacted in accordance with due process and, which affects, inter alios, a foreign investor or investment is not deemed expropriatory and compensable unless specific commitments had been given by the regulating government to the then putative foreign investor contemplating investment that the government would refrain from such regulation." 120

Government conduct may be judged as either lawful or unlawful in international investment law, if it results in causing harm to foreign investors and/or investments. Generally, when a government takes or harms the property of a foreign investor, it is considered expropriation. Expropriation is either lawful or unlawful. It is lawful if it is for a public purpose, non-discriminatory, follows due process, and compensation is paid. If there is unlawful expropriation, a breach of investment treaty law must have occurred, involving unfair or inequitable treatment.

Lawful and unlawful expropriation has different criteria for determining compensation. The recent case of $A D C v$ Hungary sheds light on this. The Tribunal explained that for lawful expropriation, compensation is calculated based on the terms of the investment treaty, which calls for fair market value before the date of the expropriation. As for unlawful expropriation, compensation is calculated based on the Chorzow Factory case, which is to put the aggrieved person in the economic position that it would have

\footnotetext{
${ }^{119}$ Compaia del desarrollode Santa Elena, S.A. v. Republic of Costa Rica, ICSID Case No. ARB/96/1, Award

${ }^{120}$ Tecnicas Medioambientales Tecmed S.A. v. The United Mexican states, ICSID Case No. ARB (AF)/00/2, Award
} 
hypothetically possessed, if not for the wrongful acts. ${ }^{121}$ Prior to 2006, compensation for unlawful expropriation was the same as lawful expropriation. Two cases relating to the expropriation of hazardous waste disposal landfills needs to be mentioned, Metalclad $v$ Mexico and Tecmed $v$ Mexico. In these two cases, the foreign investor was refused the permits necessary to carry out his hazardous waste disposal business. This was a response pursuant to community protests against the claimants. In both cases, compensation was awarded at fair market value before the date of the expropriation. This compensation covered both the expropriation and the breach of the fair and equitable treatment standard. ${ }^{122}$

There have been several major international arbitrations where the Tribunal found the state had lawfully expropriated the foreign investor's investment. Two such cases are Aminoil $v$ Kuwait and Santa Elena $v$ Costa Rica. ${ }^{123}$ In Aminoil, the Tribunal gave itself the role of judging which standard of compensation was to be used. It cited the UN General Assembly Resolution 1803, which used the 'appropriate compensation' standard. ${ }^{124}$

As is evident, Tribunals are not unanimous in dealing with the issue of legitimate government measures. Recent BITs have included more specific carve-out provisions for regulatory measures, including the US Model BIT and the ASEAN Investment Agreement. ${ }^{125}$

The deprival of a foreign investor of legitimate business expectations is recognized by more and more arbitral tribunals. When an indirect expropriation is claimed, tribunals usually determine whether the actions of the government have led to the foreign investor not being able to realize legitimate expectations. This has been codified in recent BIT's, such as the 2004 Canadian Model BIT. The typical criterion for tribunals is to look at the reasonableness of an investor's expectations, to see if indirect expropriation has taken

\footnotetext{
${ }^{121}$ China-New Zealand FTA, Chapter 11 (2008)

${ }^{122}$ Metalclad Corporation v. The United Mexican States, ICSID Case No. ARB(AF)/97/1 para 112; Técnicas Medioambientales Tecmed, S.A. v. The United Mexican States, ICSID Case No. ARB (AF)/00/2 para 151 and para 187

${ }^{123}$ Sergey Ripinsky, Kevin Williams, Damages in International Investment Law (BIICL, 2008) 384

${ }^{124}$ Stephan W. Schill, The Multilateralization of International Investment Law (Cambridge University Press, 2009) 37

${ }^{125}$ Julien Chaisse, Sufian Jusoh, The ASEAN Comprehensive Investment Agreement: The Regionalisation of Laws and Policy on Foreign Investment (Edward Elgar Publishing, 2016) 85
} 
place. $^{126}$

The requirement of the government measure being in the public's interest is defined differently by different treaties and tribunals. In the Canada-Colombia FTA (2008), it is stated in the footnote:

The term 'public purpose' is a concept of public international law and shall be interpreted in accordance with international law. Domestic law may express this or similar concepts using different terms, such as 'social interest', 'public necessity' or 'public use'. ${ }^{127}$

Indeed, the definition of public interest, or public purpose, is a broad one but there are some specific guidelines... The government's actions must be in the public interest at the time when the expropriatory measure was taken. If the goal of the measure is not achieved, it can still be considered part of the public interest. ${ }^{128}$

However, if the expropriation took place, and the public interest purpose did not start until a later date, then it cannot be considered to have originally been for the public's interest, as seen in Siag and Vecchi $v$ Egypt. In that case, expropriation occurred by the government due to delays in construction of a project. Six years later, the property was transferred to another company for the purpose of building an oil pipeline. The public purpose requirement was not met as the measure was not originally for a public purpose, but only at a later date became for a public purpose. ${ }^{129}$

The second requirement for lawful expropriation of property under international law is that it must be non-discriminatory. The expropriation is discriminatory if it is based on, linked to, or taken for reasons of the investor's nationality. ${ }^{130}$ Measures affecting only a portion of foreign nationals are not always considered discriminatory. There must be different treatment to different parties under the same measure. This can be seen in the case of Eureko v. Poland, where the Tribunal held that:

\footnotetext{
${ }^{126} \mathrm{C}$ Line L Vesque, Armand L. C. De Mestral, Improving International Investment Agreements Routledge research in international economic law (Routledge, 2013)74

${ }^{127}$ Konstantin Katzarov, The Theory of Nationalisation (Springer Science \& Business Media, 2012) 119

${ }^{128}$ Tom Allen, The Right to Property in Commonwealth Constitutions (Cambridge University Press, 2000) 23-24.

${ }^{129}$ Panitchpakdi Supachai, Expropriation: A Sequel (UNCTAD, 2012) 31-32

130 ibid 34
} 
...the measures taken by [Poland] in refusing to conduct the IPO [purchase of additional shares] are clearly discriminatory. As the Tribunal noted earlier, these measures have been proclaimed by successive Ministers of the state Treasury as being pursued in order to keep PZU [the privatized state-owned insurance company] under majority Polish control and to exclude foreign control such as that of Eureko. That discriminatory conduct by the Polish Government is blunt violation of the expectations of the Parties in concluding the SPA [Share Purchase Agreement] and the First Addendum. ${ }^{131}$

Therefore it can be concluded that non-discriminatory treatment requires that the government does not have a specific intention to expropriate from a certain nationality of foreign investors.

The third requirement for lawful expropriation under international law is that it must be done under the due process of law. The due process principle means that (a) the expropriation complies with the procedures of the domestic law and internationally recognized rules, and (b) that the investor affected has an opportunity to have his case reviewed before an independent and impartial body. The expropriation must be free from arbitrariness. ${ }^{132}$

Common examples of breach of due process would be if the expropriation has no legal (whether in law or procedure) basis to be ordered, or if the investor cannot rely on domestic courts or tribunals to hear its case impartially. ${ }^{133}$ The case of $A D C$ v. Hungary gives a more comprehensive overview:

...'due process of law', in the expropriation context, demands an actual and substantive legal procedure for a foreign investor to raise its claims against the depriving actions already taken or about to be taken against it. Some basic legal mechanisms, such as reasonable advance notice, a fair hearing and an unbiased and impartial adjudicator to assess the actions in dispute, are expected to be readily available and accessible to the

\footnotetext{
${ }^{131}$ Eureko B.V. v. Republic of Poland, Partial Award 37

132Ibrahim F. I. Shihata, Legal Treatment of Foreign Investment: "The World Bank Guidelines" International Studies in Human Rights (Martinus Nijhoff Publishers, 1993) 299

${ }^{133}$ Andrew Paul Newcombe, Lluís Paradell, Law and Practice of Investment Treaties: Standards of Treatment (Kluwer Law International, 2009) 375
} 
investor to make such legal procedure meaningful. In general, the legal procedure must be of a nature to grant an affected investor a reasonable chance within a reasonable time to claim its legitimate rights and have its claims heard. If no legal procedure of such nature exists at all, the argument that 'the actions are taken under due process of law' rings hollow. ${ }^{134}$

The last requirement to expropriate is that there must be payment of "prompt, adequate, and effective" compensation. The issue of compensation will be discussed infra.

\subsubsection{Energy Charter Treaty and Expropriation}

After looking at how expropriation can be defined, and what are the conditions of legitimate expropriation in international practice, let me move onto the Energy Charter Treaty itself. Regarding the issue of expropriation, this Treaty uses the "standard" formula, which is based on the traditional Hull doctrine regarding taking of foreign property: 135

Investments of Investors of a Contracting Party in the Area of any other Contracting Party shall not be nationalized, expropriated or subjected to a measure or measures having effect equivalent to nationalization or expropriation (hereinafter referred to as "Expropriation") except where such expropriation is:

(a) for a purpose which is in the public interest;

(b) not discriminatory;

(c) carried out under due process of law; and

(d) accompanied by the payment of prompt, adequate and effective compensation. ${ }^{136}$

\footnotetext{
${ }^{134}$ Krista Nadakavukaren Schefer, International Investment Law: Text, Cases and Materials (2nd edn, Edward Elgar Publishing, 2016) 204

${ }^{135}$ Sanam S. Haghighi, Energy Security: The External Legal Relations of the European Union with Major Oil and Gas Supplying Countries (Bloomsbury Publishing, 2007) 211

${ }^{136}$ Ilias Bantekas, John Paterson, Maidan Suleimanov, Oil and Gas Law in Kazakhstan: National and International Perspectives (Kluwer Law International, 2004) 58, See also Zoltan Víg, Requirements of lawful taking of foreign property in international law (Iurisperitus Kiado, Szeged, 2016)
} 
So, we can see that the Energy Charter Treaty's provision does not only refer to direct expropriation, but also to indirect or creeping expropriation, the concept of which was explained previously.

Furthermore, expropriation is a very frequent element of cases under the Energy Charter Treaty, where the tribunals have to specify and iterate on the provisions of the treaty concerning expropriation. To list a few cases, a good example of the concept of expropriation under the Energy Charter Treaty cropping up is the previously mentioned Petrobart v. Kyrgyzstan, where one of the breaches of the Energy Charter Treaty stated by the Claimant was that the Respondent's actions amounted to illegitimate expropriation under the Energy Charter Treaty. The Fuchs v. Georgia case also concerned expropriation, in this case the expropriation of the property of the Claimant (an oil pipeline) through a governmental decree. Likewise, Azpetrol v. Azerbaijan also concerned expropriation under the Energy Charter Treaty. In Cementownia v. Turkey, the Claimant alleged expropriation under the Energy Charter Treaty, besides other claims.

In conclusion, we can see that expropriation is a "popular" claim in disputes under the Energy Charter Treaty. This is hardly surprising, given that expropriation is one of the major reasons for disputes between foreign investors and host states. Thus, Tribunals had to interpret the Energy Charter Treaty's concept of expropriation several times as in the aforementioned cases.

\subsection{Compensation}

Expropriation raises another issue. When a host country expropriates or takes a foreign property for the public interest, it becomes the owner of that property. However, the host country then has to compensate the original owner in return for the expropriation. Expropriation is of course a right of the host state, which is recognized by international institutes and charters. These charters legitimize the expropriation, but also the reparation of the loss for the foreign investors through compensation. ${ }^{137}$

\footnotetext{
${ }^{137}$ Boleslaw Adam Boczek, International Law: A Dictionary (Scarecrow Press, 2005) 148
} 
The United Nations General Assembly in its Resolution of 1803 issued on September 18, 1962, which is relates to full sovereignty of states over their national resources according to Article 4, states:

... Commission on Permanent Sovereignty over Natural Resources and instructed it to conduct a full survey of the status of permanent sovereignty over natural wealth and resources as a basic constituent of the right to self-determination, with recommendations, where necessary, for its strengthening, and decided further that, in the conduct of the full survey of the status of the permanent sovereignty of peoples and nations over their natural wealth and resources, due regard should be paid to the rights and duties of states under international law and to the importance of encouraging international cooperation in the economic development of developing countries. ${ }^{138}$

States when exercising this right need to take into consideration the rules of law and work towards the general interest of all. The best way for this is to oblige host states to pay appropriate compensation. ${ }^{139}$

As a further addendum, Recommendation no. 3171 of the United Nation General Assembly has reestablished the same principle and the same conditions. The Recommendation gave the power to determine the amount of appropriate compensation and the way of paying the compensation to the state, as long as it is within its competences and sovereign authority. ${ }^{140}$ Furthermore, this principle was noted by the Declaration of Human and Civil Rights of August 26, 1789, which said that: "Since the right to Property is inviolable and sacred, no one may be deprived thereof, unless public necessity, legally ascertained, obviously requires it, and just prior indemnity has been paid". ${ }^{141}$

In general, international investment law and treaty arbitration are in the domain of public

\footnotetext{
${ }^{138}$ General Assembly resolution 1803 (XVII) of 14 December 1962, 'Permanent sovereignty over natural resources' < http://www.ohchr.org/Documents/ProfessionalInterest/resources.pdf $>$ accessed 04 March 2017

${ }^{139}$ Wayne Mapp, The Iran-United states Claims Tribunal: The First Ten Years, 1981-1991 : an Assessment of the Tribunal's Jurisprudence and Its Contribution to International Arbitration (Manchester University Press, 1993) 170

${ }^{140}$ Jeswald W. Salacuse, The Law of Investment Treaties (Oxford University Press, 2015) 80

141 Declaration of Human and Civic Rights of 26 August $1789<$ http://www.conseil-constitutionnel.fr/conseilconstitutionnel/root/bank_mm/anglais/cst2.pdf> accessed 04 March 2017
} 
international law. Therefore, when a foreign investment is expropriated or otherwise hampered, it could be argued that there is a breach of international law. And a breach of treaty or international law may result in reparations, which is a basic principle of state responsibility. State responsibility is the doctrine that is invoked when there is an internationally wrongful act by a state. A state may be held accountable, and obliged to pay reparations (typically involving compensation) if it breaches a treaty or international law. ${ }^{142}$

When it comes to these reparations in the context of foreign investment, some developing nations use the term "appropriate compensation" in their bilateral contracts. This is a vague standard, but the UN also uses this wording, so that in the event the states are unable to pay immediate and full compensation, they can still expropriate foreign property due to national public interest. ${ }^{143}$

By contrast, capital exporting states are now more uniform in using the Hull standard. As mentioned before in this part, the Hull standard means "prompt, adequate, and effective" compensation. It requires the payment of compensation of full market value, without delay, and in easily convertible currency. ${ }^{144}$

The Hull formula was originally formulated to provide a more satisfactory and agreeable compensation for the investor, whereas the appropriate compensation formula favors the state, as other factors and considerations may be taken into account to lower the amount of compensation. Specific considerations are rephrased as "just" or "appropriate" when the context is uncertain, such as the time frame of payment, the type of currency, and the transferability of the payment.

We can thus conclude that there is international unanimity about the right of foreign investors to get some form of compensation after their properties were expropriated by host states. However, the way to pay the compensation, the quantity of the compensation and the time of payment are all relative. It depends on the financial and economical capabilities of the states on one hand, and political and legal circumstances on the other

\footnotetext{
${ }^{142}$ Borzu Sabahi, Compensation and Restitution in Investor-state Arbitration: Principles and Practice (International Economic Law Series, OUP Oxford, 2011) 7

${ }^{143}$ United Nations, 'Taking of Property' (New York and Geneva, 2000) 13-15. < http://unctad.org/en/docs/ psiteiitd15.en.pdf $>$ accessed 06 June 2017
}

${ }^{144} \mathrm{M}$. Sornarajah, The International Law on Foreign Investment (Cambridge University Press, 2010) 414 
hand. Therefore, the next step should be to discuss the various intricacies of compensation.

\subsubsection{The Standard of Compensation for Expropriation in Investment Treaties}

\section{The view of international treaties about compensation}

As mentioned already in the previous segment briefly, in bilateral and multilateral international treaties the obligation of paying compensation is mentioned. To take foreign properties or to expropriate the property of the foreign investor is an arbitrary exercise of state power, which prevents the foreign investor from enjoying the rights connected to the property. The right of expropriation and all other sovereign absolute rights of states are limited by bilateral treaties and collective international treaties, which the states have signed. The goal of these international treaties is to limit the states' rights, to ensure general guarantees for international business and also to ensure guarantees of covering the investment lost by the expropriation. ${ }^{145}$

When compared to domestic law, international treaties have other dimensions too. Sometimes, a state does not fulfill its responsibility according to the given international treaty. If the foreign investors face such an issue, the investors could present a claim before a local court just in the same way as a local people. In the case of depleting all judicial routes before the domestic court, the investors could apply for diplomatic protection to their own country against the host state. ${ }^{146}$

Analysis of Hull formula, 'prompt' means that compensation should be granted to an investor as soon as the investment is expropriated. Often this should be an amount equal to the value of losses suffered and loss of profits. The term 'effective' means that the amount should be paid in a freely convertible and transferable currency. ${ }^{147}$

Apart from the "Hull" standard in determining compensation, in that it must be prompt,

\footnotetext{
${ }^{145}$ Dennis Campbell, International Protection of Foreign Investment ( $2^{\text {nd }}$ edn, Juris Publishing, 2009) 28-29

${ }^{146}$ Vienna Convention on the law of treaties of 23 May $1969<\mathrm{https}: / /$ treaties.un.org/doc/publication/unts/volume\%201155/volume-1155-i-18232-english.pdf> accessed 06 March 2017

${ }^{147}$ Zoltan Víg, Requirements of lawful taking of foreign property in international law (Iurisperitus Kiado, Szeged, 2016) 46-48.
} 
adequate, and effective there are other standards of compensations which will be explored below.

A majority of investment treaties monitored by UNCTAD contain four requirements for a lawful expropriation: it must be for a public purpose, it must be non-discriminatory, and there must be due process and payment of compensation as already mentioned. As far as compensation standards, most BITs currently use the language of the Hull formula but they differ on the degree of specificity and factors in the calculation and payment of compensation. ${ }^{148}$

A very specific compensation provision can be found in Article 6(2) of the 2004 US Model BIT. It further specifies that:

2. The compensation referred to in paragraph 1(c) shall:

(a) be paid without delay;

(b) be equivalent to the fair market value of the expropriated investment immediately before the expropriation took place ("the date of expropriation"); (c) not reflect any change in value occurring because the intended expropriation had become known earlier; and (d) be fully realizable and freely transferable. ${ }^{149}$

The first three subarticles (a),(b) and (d) represent the prompt, adequate, and effective elements. Subarticle (c) mitigates any damage to the value of the property. Subarticle (b) attaches the term "fair market value" to the adequate part of the Hull formula. It is intended to be more specific. Article 6(2) is therefore a more sophisticated version of the Hull formula. 150

The standard of appropriate compensation is preferred by host states because it is a broad standard and can take into account factors such as profits made by the foreign investor, or under what time frame the profit was made. Developing nations have also pushed to give

\footnotetext{
${ }^{148}$ UNCTAD, Bilateral Investment Treaties 1995-2006: Trends in Investment Rulemaking (United Nations, 2007) 52

${ }^{149}$ Borzu Sabahi, Compensation and Restitution in Investor-state Arbitration: Principles and Practice (OUP Oxford, 2011) 93

${ }^{150}$ China-Germany BIT, Article 4.2 (2003); Egypt-Indonesia BIT, Article 4 (1994)
} 
tribunals the power to decide the amount of compensation. Due to this conflict between the standards of compensation, bilateral investment treaties were borne to protect both parties from the uncertainty of which standard is to be used. ${ }^{151}$

Most of the recent bilateral investment treaties specify the payment of prompt, adequate, and effective compensation as the standard. ${ }^{152}$ It also requires the standard of valuation to be the fair market value immediately before the expropriation took place. ${ }^{153}$ The US Model Treaty of 2004 also includes this standard. ${ }^{154}$ Nevertheless, there are numerous bilateral treaties that use other standards for valuation. There have been many attempts of reaching uniformity, in order to reduce deviations. For example, the Hull standard is used in treaties between the UK and Switzerland, ${ }^{155}$ whereas between Netherlands and Germany, the BIT uses the just compensation standard. There are many other examples of variations in BITs between different nations around the world. These 'drafting variations' are sometimes due to the bargaining strengths or strategies of either party. Sometimes, it is a compromise or a hybrid formula due to some regional conflict. It is important to consolidate these into a uniform standard because although prompt, adequate, and effective may be similar to just or full compensation, they do not have the exact same meaning. ${ }^{156}$ Developing nations in particular often advocate the appropriate compensation formula on the international level, but then privately use the Hull formula to attract foreign investment. Therefore, calling variations as "inconsistencies" may not be an accurate way of describing them. ${ }^{157}$

The concept of appropriate compensation should also be discussed in more detail. Appropriate compensation is determined by two factors. Firstly, the compensation should be

\footnotetext{
${ }^{151}$ Deming Chen, Economic Crisis and Rule Reconstruction (World Scientific, 2016) 406

${ }^{152}$ Maria A. Gwynn, Power in the International Investment Framework (Springer, 2016) 103

${ }^{153}$ Pedro J. Martinez-Fraga, C. Ryan Reetz, Public Purpose in International Law (Cambridge University Press, 2015) 68

${ }^{154}$ Chester Brown, Commentaries on Selected Model Investment Treaties (OUP Oxford, 2013) 32

${ }^{155}$ Loretta Malintoppi, Charis Tan, Investment Protection in Southeast Asia: A Country-by-Country Guide on Arbitration Laws and Bilateral Investment Treaties (BRILL, 2016) 131

${ }^{156}$ C. F. Amerasinghe, 'Issues of Compensation in the Taking of Property in the Light of Recent Cases and Practice' (1992) 41 ICLO 22

${ }^{157}$ A. Guzman, 'Why LDCs Sign Treaties That Hurt Them: Explaining the Popularity of Bilateral Investment Treaties' (1998) 38 Virginia Journal of International Law 639
} 
equal to the harm or damage without any additional interest. ${ }^{158}$ This factor depends on direct harm, which contains the amount of damage and the lost profit, without taking into account the intensity of the error or the legal and financial status of the subject. The United States of America has applied the Hull formula explanation to the meaning of appropriate compensation as an adequate, prompt and effective form of compensation. ${ }^{159}$

Secondly, for the estimation of the compensation, the circumstances of taking the property or expropriation should be put into consideration. ${ }^{160}$ Therefore, the amount of the appropriate compensation depends on the intensity of harm or damage, which affects the foreign investor. However, the estimation of the damage and the question of intensity is a discretionary power of the judge. The time for the estimation of the compensation is usually the time when the damage happened. The reason for this is that the damage usually occurs after the expropriation procedure had begun, and thus it is necessary to establish the right to compensation at that time. Some scholars believe that appropriate compensation should be based on the time the claim to ask for compensation has been put forward by the investor, and not at the time of the expropriation procedure or at the time when damage occurred. Between these different explanations of appropriate compensation, a new view has been raised. This said that the time of expropriation procedure should be used for covering the damage, and the compensation should be paid at the time of court verdict. International law views appropriate compensation as a compensation allowing the host state to cover the actual value of the foreign investment, taking into consideration the damage and loss affecting the investor, who is left without possible future profit. This kind of compensation is welcomed by many foreign investors, and most prefer to use it in international business transactions. ${ }^{161}$

The next concept to be discussed is the related concept of immediate compensation, which is similar to the Hull standard. Immediate compensation is a compensation given by a host

\footnotetext{
${ }^{158}$ Borzu Sabahi, Compensation and Restitution in Investor-state Arbitration: Principles and Practice (OUP Oxford, 2011) 96

${ }^{159}$ Stephen M. Schwebel, 'The story of the UNs Declaration on Permanent Sovereignty over National Resources' (1963) 49 American Bar Association Journal 463-465

${ }^{160}$ Sangwani Patrick Ng'ambi, Resource Nationalism in International Investment Law (Routledge, 2015) 82

${ }^{161}$ Ben Ablia, Les aspects actuels des problèmes d'indemnisation en droit international (DPhil thesis, Université Paris I, 1980) 142
} 
state immediately after the expropriation to the investor. At the time of expropriation and transfer of ownership from the investor to the host state, the compensation should be estimated and be paid by the host state and so if there is any delay in paying the compensation, then additional delay time should be attached with interest. ${ }^{162}$ The aim of accepting this compensation by the investor is to gain time and to not lose more money. The immediate compensation means the full amount of the actual compensation should be paid at the time of expropriation including all lost profit and an estimate of the investment's value, according to the market price at that time. Some scholars believe that if there is compensation in advance, or if the compensation is given before the expropriation occurs, or the compensation is at the time of expropriation but before the transfer the ownership, it can be called immediate compensation. For instance, this form of "in advance" compensation was recommended by the American Institute of International Law, with its draft from 1925 and also the International Law Association, ${ }^{163}$ and the Vienna rules in 1926. ${ }^{164}$

However, when it comes to implementing this kind of compensation, there is no international rule that obligates states to accept this type of immediate compensation, because immediate compensation depends on the economic and financial capacity of the host state. The economic and social situations were crucial for some host states in determining when to consider the payment of the compensation to be on time. There are some bilateral treaties, in which the conditions of immediate compensation were mentioned, such as the bilateral treaty between Algeria and China. In the treaty it is stated that the compensation must be equal to the value of the investment that has been taken or expropriated at the time it was publicly announced. The compensation should be paid immediately without any delay. ${ }^{165}$

Finally, actual compensation is a conception that should also be examined which roughly analogous to the effective element of the Hull standard. Actual compensation is the de-

\footnotetext{
${ }^{162}$ China-France BIT (1984)

${ }^{163}$ United Nations, Yearbook of the International Law Commission 2000 (United Nations Publications, 2010) 241.

${ }^{164}$ D. P. O'Connell, The Law of state Succession (Cambridge University Press, 2015) 102

${ }^{165}$ China-Algeria BIT (1996)
} 
served compensation that the investor gets in cash in a convertible currency. ${ }^{166}$ It is a deserved compensation in return for taking the investors' property and expropriation by a host state. The investment could be tangible or intangible rights with financial value. ${ }^{167}$ The compensation is actual when the host state is ready to pay the compensation in cash in a local or foreign currency and the exchanging of the currency and transfer of money according to the market price and convertible currency. ${ }^{168}$

It is possible for both parties to agree to pay the compensation in a different way. For instance, in the bilateral agreement between Libya and Texaco in 1977, the Libyan government agreed to pay to the investors an amount of crude oil that was equal to the actual compensation, which was $\$ 76$ million dollars, in return for the investment expropriation by Libya. ${ }^{169}$

\section{The view of international courts over compensation}

Before moving onto the Energy Charter Treaty, let me briefly discuss the view of international courts with regards to compensation. The General Claims Commission (Mexico, United states of America) notes that a state, of which the investor is a citizen, has the right to demand adequate compensation for its citizen according to rules of international law, after its citizen was affected by host state action. ${ }^{170}$

The reason for this is because the foreign person's state usually has an interest in ensuring respect for international law, and this interest is greater than the one to get compensation for one of its citizens. The International Court of Justice confirmed that the principle obligating the host states to pay an appropriate compensation is the main principle for repairing

\footnotetext{
${ }^{166}$ Adeoye A. Akinsanya, The Expropriation of Multinational Property in the Third World (Praeger, 1980) 45

${ }^{167}$ James M. Wahlen, Jefferson P. Jones, Donald Pagach, Intermediate Accounting: Reporting and Analysis (Cengage Learning, 2015) 122

${ }^{168}$ Adeoye A. Akinsanya, The Expropriation of Multinational Property in the Third World (Praeger, 1980) 45

${ }^{169}$ LIAMCO v. The Government of the Libyan Arab Republic, YCA 1981, Award (1977)

${ }^{170}$ Santiago Montt, State Liability in Investment Treaty Arbitration: Global Constitutional and Administrative Law in the BIT Generation Studies in International Law (Bloomsbury Publishing, 2009) 56
} 
the damage after the expropriation occurred. ${ }^{171}$ Sometimes, the compensation was implemented in a different way. For instance, according to the agreement between the Bolivian government and the Bolivian Gulf Oil Company in 1971, the Bolivian government paid some amount of gas to the company in return for the expropriation. ${ }^{172}$

An international arbitration award in the case of LIAMCO stated that compensation has to be paid, because it is the main condition for exercising the right to expropriation for host states, in accordance with commonly accepted international and national law. ${ }^{173}$ The necessity of compensation was confirmed by the CJEU in the case of Lithgow and others $\mathrm{v}$ the United Kingdom in 1986. The shipyard was expropriated by the government of United Kingdom. The decision of the CJEU was that the amount of the compensation in case of expropriation may not be the same as the compensation in the case of preventing the foreign investor from enjoying its property. ${ }^{174}$

However, regarding the form of the compensation, almost all agreements relate to investment dispute settlement. In international commercial arbitration, the arbitrators also have the freedom to choose appropriate form of compensation to repair the damage caused by the expropriation. The International Court of Justice was given this authority based on Article $36(2) .{ }^{175}$

\section{Energy Charter Treaty, investment protection and compensation}

When it comes to the Energy Charter Treaty, it adopts the "Hull" standard in determining compensation, in that it must be prompt, adequate, and effective. ${ }^{176}$

However, there are issues in using the Hull standard. Before determining if there is a duty for the host state to pay compensation, the tribunal must look into the character of the gov-

\footnotetext{
${ }^{171}$ Texaco Overseas Petroleum Co. v. Libya, 17 I.L.M. 1 (1978)

172James F. Siekmeier, The Bolivian Revolution and the United states from 1952 to the Present (Penn State Press, 2011) 126

${ }^{173}$ Francis Woodie, Nationalisation, indemnisation et développement, colloque international d'Alger (1976) 165

${ }^{174}$ Lithgow v UK App no 9006/80 (ECtHR, 8 July 1986) 44

175 Statute of the ICJ, Article 36 (2)

${ }^{176}$ Panitchpakdi Supachai, Expropriation: A Sequel (UNCTAD, 2012) 40
} 
ernment action that may have caused indirect expropriation. If the expropriatory nature of the measure is being disputed, then it would not be fair for the host government to have already paid compensation if it did not think it was required to. Therefore, a distinction is made between unlawful sub modo, meaning it would have been lawful expropriation if compensation was paid, and unlawful per se, meaning that there is a breach of the essential conditions of expropriation. ${ }^{177}$

Furthermore, Article 10(1) requires the host states to provide constant protection and security to the investment. This means that the host state must take all steps necessary to ensure investments are not damaged or destroyed. This clause could be invoked in areas where there is civil unrest or political violence. Lastly, Article10 (1) contains an umbrella clause that reads "observe any obligations it has entered into with the Investor or an Investment." This is merely to ensure that all contracting parties comply with their contractual obligations in good faith. ${ }^{178}$ A good example of an Article 10 (1) violation in this context is the Nykomb v. Latvia case, where the Tribunal acknowledged that Latvia (through its state-owned company) entered into an agreement with the foreign investor, which the government later violated. Another example is Ascom v. Kazakhstan, where an Article 10 (1) breach was claimed by the Claimants. Furthermore, another case concerning Moldova, the Energorynok v. Moldova case, also dealt with an alleged Article 10 (1) breach. Finally, the Mamidoil v. Albania case also dealt with the violation of this obligation to provide protection and security to the investment.

The last two investment protections in relation to Article 10 are the most favored nation (MFN) clause, and the minimum standard clause. The MFN principle is enshrined in Article 10(3) and (7) which states:

(3) For the purposes of this Article, "Treatment" means treatment accorded by a Contracting Party which is no less favorable than that which it accords to its own Investors or to Investors of any other Contracting Party or any third state, whichever is the most favorable

... (7) Each Contracting Party shall accord to Investments in its Area of Investors of

\footnotetext{
177ibid 43-44

${ }^{178}$ L. Reed, L. Martinez, 'The Energy Charter Treaty: An Overview' (2008) 14.2 ILSA Journal of International \& Comparative Law 414
} 
other Contracting Parties, and their related activities including management, maintenance, use, enjoyment or disposal, treatment no less favorable than that which it accords to Investments of its own Investors or of the Investors of any other Contracting Party or any third state and their related activities including management, maintenance, use, enjoyment or disposal, whichever is the most favorable.

These provisions have multiple components to ensure the protection of investments. They call upon the contractual parties to encourage fair and equitable treatment of each other. They secure a commitment from both contractual parties to observe their contractual agreement. They discourage arbitrary breaches of contract in both monetary and physical ways. Article 10(12) furthermore ensures that investors can enforce their claims and rights in the domestic law of the host state. Article 10(12) was, for example, referenced in the previously mentioned Petrobart v. Kyrgyzstan case, where the foreign investor claimed a violation of this principle. This provision was also raised in the Energoalliance v. Moldova case, where the foreign investor also claimed a violation of this principle. In both cases, however, the Tribunal ultimately did not base its decision on the violation of this principle. Article $11^{179}$ of the Energy Charter Treaty involves allowing key personnel of any contractual party to be able to engage in activities and remain temporarily in the area of the host state, subject to terms and conditions granted to the key persons. This dissertation ensures that the contracting party, which has invested in a foreign state, has access to its investment and is able to operate, manage, and maintain its property.

When any type of breach occurs concerning an investment, compensation must be provided according to the legal standard to the aggrieved party. Article 12 of the Energy Charter Treaty provides investors with indemnification and compensation owing to any war, other armed conflict, state or national emergency, or civil disturbance. If an investor suffers a loss whether by requisitioning by the host state, or by the destruction of the property without necessity, the standard for compensation is prompt, adequate, and effective. ${ }^{180}$

In conclusion, compensation is a tricky question that is interpreted differently by the various interested parties. In general, the "Hull" interpretation seems to be the most popular,

\footnotetext{
${ }^{179}$ Energy Charter Treaty, Article. 11

${ }^{180}$ Energy Charter Treaty, Article. 12
} 
but we cannot dismiss the other compensation concepts. As for the tribunals, we can see that they take slightly different approaches to the question of compensation. This will be further elaborated on in the next part of the dissertation, where I will examine Energy Charter Treaty case law in detail.

\subsection{Case law related to art. 10 and 13}

There are more than a hundred investment dispute settlement cases related to the Treaty. However, only less than half of these cases are the awards published. In the following I am going to examine some of these cases which I have selected based on their relevance to the theoretical background that was examined by the dissertation in the previous parts. That is to say, these cases are tied to the concept of investment protection and expropriation.

One of the very first cases was the Nykomb Synergies Technology Holding AB (as the Claimant) versus Republic of Latvia (as the Respondent). ${ }^{181}$ In this case, the Claimant, a Swedish company, acquired 100\% ownership of Latvian owned company SIA Windau in September 2000. The company produced electric power and heat. ${ }^{182}$ A Latvian state owned company named Latvenergo ("Latvenergo") which formed in 1991. In 1997, Latvenergo entered into a contract with Windau, owned by the Claimant, to build a power plant and produce energy and heat to be distributed and delivered to the Bauska municipality. The power plant was completed and a contract was entered for Nykomb to sell the energy and heat at double the tariff rate for the first eight years of production. By amendment to Latvian Energy Law on August 3, 2000 energy was not to be privatized as it was a national economy object of the state economy. This made Latvenergo a state monopoly on energy control, regulation, and pricing. It changed the multiplier from the double tariff rate, to a multiplier of .75. The Claimant then halted production, demanding the original contractual rate of double tariff rate, while Latvenergo refused. 183

\footnotetext{
${ }^{181}$ Nykomb Synergies Technology Holding AB v Republic of Latvia, SCC - Case No 118/2001.

${ }^{182}$ Nykomb Synergies Technology Holding AB v Republic of Latvia, IIC 182 (2003)

183ibid para 1.1
} 
The Claimant claimed that the Respondent, by not paying the double tariff rate as agreed by the contract, and while paying other Latvian energy companies the double tariff rate, had breached its contractual obligations under the Energy Charter Treaty. It prayed for relief of all the loss of income incurred from the halt of production of energy and heat while the double tariff rate was not being paid, in addition of future losses incurred. It claimed the Respondent violated Article 10(1) and 13(1) for fair and equitable treatment, less favored nation treatment, unreasonable and discriminatory measures, and actions equivalent to expropriation. 184

The Respondent argued that Latvenergo's conduct are not attributable to Latvia, that it had not contravened its obligations under Part III of the Treaty, that Nykomb had not suffered any loss warranting compensation, and that all costs of the Arbitration should be borne by the Claimant. Essentially their argument was that changes in Latvian law are not attributable to Latvenergo on the grounds that acts of Parliament cannot be construed to be acts by Latvenergo. By amending the Latvian Energy Act, Latvenergo was merely to enforce any changes in Tariff rates that the Latvian Energy Council was to recommend ${ }^{185}$. The Arbitral Award held, inter alia, that the Respondent did violate its obligations under Article 10(1) and 13(1) of the Energy Charter Treaty. Changes in the average sales price are allowed to be changed, but the multiplier of the tariff rate was a violation of its contractual obligations with the Claimant. The Arbitral Award granted the loss of income claimed by the Claimant, but denied the claim for future losses, as they are speculative and immeasurable. The Arbitral Tribunal rejected that contention of the Respondent that a force majeure clause allowed it to change the multiplier of the tariff rate. In fact, the contract is vague as to whether it is merely an interim agreement. Despite legislation, the multiplier rate should have continued for the 8 years after production as stipulated by the contract between the parties. ${ }^{186}$

In the next case, in Petrobart Limited (as Claimant) versus the Kyrgyz Republic (as Re-

\footnotetext{
${ }^{184}$ ibid para 1.2 .3

185ibid para 1.3

186ibid para 4.2
} 
spondent), the Claimant was a company registered in Gibraltar ${ }^{187}$. In February 1998, it entered into a contract with Kyrgyzgazmuniazat (KGM) for 120,000 tons of gas condensate. In March of the same year, Petrobart delivered the gas condensate and invoiced KGM for $\$ 2,457,620$. KGM made the first 2 payments amounting to $\$ 951,976$. It failed to settle the rest of the balance due to financial difficulties, and subsequently suspended further deliveries. $^{188}$

At the local Court in Bishkek, Petrobart obtained a debt judgment of $\$ 1,507,812$. However, prior to this, by Presidential Decree in September 1998, KGM's assets were to be sold off to 2 other state entities. It subsequently was granted a stay of execution on the debt judgment for 3 months. During those 3 months, KGM sold off the assets to the $3^{\text {rd }}$ party entities, and was declared bankrupt. In 2003, Petrobart initiated arbitration proceedings under Article 26 of the Energy Charter Treaty which came into force in 1998 in Kyrgyzstan. ${ }^{189}$ Petrobart claimed that Kyrgyzstan breached several obligations under the Energy Charter Treaty. It claimed that the respondent breached Article 10(1) of the Energy Charter Treaty by not creating stable, favorable, and transparent conditions. It claimed the respondent's domestic law did not provide effective means for the assertment of claims and enforcement of rights with respects to investment, as required under Article 10(12). It claims the breach amounted to an expropriation, contrary to Article 13(1). It lastly claimed that state owned entities did not act in a manner consistent with its obligations, in breach of Article 22(1). It requested compensatory damages of the debt judgment, plus interest, as well as for further loss of profits. ${ }^{190}$

The Kyrgyz Republic contested the arguments raised by the claimant. It claims that Petrobart does not have an "investment" in the country as defined by Kyrgyz Foreign Investment Law. It asserts that the transferring of KGM's assets were part of a stabilization programme, not to treat its creditors unfavorably. It claims that the stabilization programme complied with The Kyrgyz Investment Law. It also claims that the Kyrgyz Republic did not act in bad faith, or to deprive the claimant, and did not benefit from the bankruptcy of

\footnotetext{
${ }^{187}$ Petrobart Limited v The Kyrgyz Republic, SCC Case No. 126/2003

$188_{\text {ibid } 5}$

$189_{\text {ibid }} 6$

$190_{i b i d} 25-35$
} 
KGM. ${ }^{191}$

The Arbitral Tribunal accepted the arguments of Petrobart. It agreed that The Kyrgyz Republic breached Article 10(1) of creating a fair, equitable, and transparent environment. This is due to the various Presidential decrees, changes to domestic law, and direct government intervention in the affairs of KGM. These created unstable and inequitable conditions for Petrobart. By requesting and being granted a stay of execution of the debt judgment, it failed to ensure Petrobart could by effective means, assert its rights in Court. It also violated Article 13(1), as the acts related to making KGM bankrupt effectively lead to an expropriation of Petrobart's investment. Petrobart was granted compensatory damages of USD $\$ 1,507,812.60$ and $\$ 2,376,339.60$ as lost future profits, among other costs. ${ }^{192}$

Another case was between Ron Fuchs (as Claimant) and the Republic of Georgia (as Respondent). ${ }^{193}$ The Republic of Georgia sought investments to develop its national energy infrastructure and develop a transit corridor that could transport oil and gas from Azerbaijan to the Black Sea (the Western Route). Meetings were held between the claimants and representatives of the Georgian Government to discuss oil exploitation. The result of these meetings was that the Georgian Minister of Industry signed a Power of Attorney on September 4, 1991 with the claimants through the company Tramex (International) Ltd, of which the 2 claimants held equal shares of. Two months later, the respondents adopted Resolution No. 834, which authorized a joint venture between SakNavtobi (the Georgian state-oil company) and Tramex for the purpose of exploiting oil fields in the Georgian territories of Ninotsminda, Manavi, and Rustavi, as well a license to export oil. The joint venture created GTI Ltd, of which Tramex and SakNavtobi held equal shares. Additionally, SakNavtobi held the rights to Georgia's main pipeline known as Transneft. ${ }^{194}$

Transneft executed a Deed of Concession in favor of GTI for 30 years over Georgia's pipelines. This was signed by the parties, as well as ratified by the Minister of Fuel and Energy. GTI started some work on different parts of the pipeline projects. Meanwhile, it

\footnotetext{
${ }^{191}$ ibid $42-53$

192ibid 73-77

${ }^{193}$ Ioannis Kardassopoulos v. The Republic of Georgia, ICSID Case No. ARB/05/18

194ibid para 69
} 
was trying to secure financing for future projects. Meanwhile, 13 multinational oil companies in December 1994 formed the Azerbaijan International Operating Company to invest in the area. The government of Georgia also created the Georgia International Operating Company to safeguard the national interests of oil in Georgia. During this time, the claimants communicated that GTI had the exclusive rights over Georgia's pipelines, and that any interference by AIOC or GIOC would result in liability for damages. On February 20, 1996 the Georgian cabinet of ministers adopted Decree No. 178 which essentially cancelled the Claimant's rights to the oil pipelines. It re-assigned these rights to the GIOC, which offered contracts to the AIOC. The Claimants then initiated claims for compensation due to the cancellation of its rights on Georgia's pipelines. The Government created a commission to assess how much compensation should be paid to the Claimants. Eventually, on November 15, 2004 the commission had decided that there was no legal ground for holding the Government liable for the claim. ${ }^{195}$

The main argument of the Claimant was that the Respondent had expropriated its property, in breach of Article 13(1) of the Energy Charter Treaty. It contended that the Respondents had breached the fair and equitable standard. It contended that the Georgian government, through various executive instruments such as Decrees by the Georgian cabinet of ministers, led to losses for the Claimant in regards to oil pipeline rights as well as ongoing oil pipeline work. It invokes the concept of State Responsibility to support its claim that Georgia should be liable. Additionally, it holds the government of Georgia responsible because SakNavtobi and Transneft are wholly owned and controlled by the Georgian state. It contended that despite 10 years having passed, it was not time barred from making the claim as it had to wait the result of the Georgian commission for compensation before it could have reasonably filed for arbitration. It seeks compensation for expropriation, as well as damages for loss of earnings, future earnings, and other damages. ${ }^{196}$

The respondent argued the arbitration tribunal did not have jurisdiction ratione temporis because treaties do not have retroactive effect. It argued that the acts occurred prior to August 3, 1996 before the Georgia/Greece BIT, and that all remained was a complaint that it

\footnotetext{
$195_{\text {ibid paras } 155-162}$

196ibid paras 304-316
} 
had failed to compensate the claimants. ${ }^{197}$ It also argued that the Claimant was time-barred from seeking arbitration as there was a delay of 10 years between the alleged acts and the claim. It argued that the Georgian government, while liable for the executive instruments used to expropriate from the Claimants, was not responsible for the contractual commitments of SakNavtobi and Transneft. It argued that the granting of GTI's rights to Georgian pipelines under the joint venture agreement and deed of concession was invalid and unenforceable. It further claims that the Claimant's did little to no work on the pipeline after the Deed of Concession was executed, and therefore can't expect to continue to hold these rights or not be bought out. ${ }^{198}$

The Arbitral Tribunal sided with the Claimants and held that it had jurisdiction to hear the case. It held that the Claimant was not time barred as the delay was reasonable, considering the Claimants had to wait for the decision of the Georgian commission in regards to compensation. It also held that the acts of SakNavTobi and Transneft were attributable to the government of Georgia on the basis of Article 7 of the Articles on State Responsibility. Most importantly, the Tribunal held that the acts of the Respondent with the adoption of Decree No. 178 had directly expropriated GTI, and therefore the claimants, of its rights and interests. The Georgian government had therefore breached their obligations to provide investors with fair and equitable treatment. It awarded the Claimants approximately USD $\$ 45$ million each in damages ${ }^{199}$.

Also there was a case between Limited Liability Company AMTO (as Claimant) and state of Ukraine (as Respondent) ${ }^{200}$. It had purchased significant shares of EYUM-10, a state owned company which was responsible for the construction of the Zaporozhskaya AES (ZAES) nuclear power plant. ZAES was run by the state-owned company Energoatom. EYUM-10 supplied services of reconstruction and technical rearmament to ZAES. By March 2003, the claimant had purchased $67.2 \%$ of the total share capital in EYUM-10. ZAES acknowledged it was in debt $\mathrm{t}$ to EYUM-10 in respect to 11 contracts between them.

\footnotetext{
197ibid para 234

198ibid paras 282-303

199ibid para 693

${ }^{200}$ Limited Liability Company Amto v. Ukraine, SCC Case No. 080/2005
} 
Between 2002 and 2003, EYUM-10 commenced court proceedings in the Commercial Court of Zaporozhskya, obtaining judgment for a total amount of 28,377,858.04 UAH. It sought execution of the judgment, but the judgment was stayed due to bankruptcy proceedings against ZAES. In July 2003, the Ukrainian Cabinet of Ministers adopted Resolution No. 1160 which ceased created special measures to discontinue operations on 'highly hazardous enterprises'. Then in July 2005, the respondent passed Law No. 2711-VI which implemented measures to support the financial standing of fuel and energy sector enterprises. This included the ability of the state to use these enterprises as business entities, and provisions on the interaction of state authorities in respect to debt repayment mechanisms. By August 2006, EYUM-10 and Energoatom signed an agreement in relation to the outstanding debts of the 11 contracts, and 2 further debt judgments of 2005. Energoatom made some of the debt repayments to reduce its outstanding debt. ${ }^{201}$

The Claimant argued that the Respondent breached its obligations under Articles 10(1), 10(12), and 22(1) of the Energy Charter Treaty. It contended that AMTO was a registered company in Latvia, a signatory to the Energy Charter Treaty, and had substantial business activities in Latvia within the meaning of Article 17(1). It contended that Energoatom was a corporate entity controlled by the state. It argued that the Respondent had failed to "encourage and create stable, equitable, favorable and transparent conditions for investors". It submitted evidence that AMTO suffered intimidation, discrimination, and constant obstruction by Energoatom after it found out about AMTO's intention to buy shares of EYUM-10. After AMTO invested in EYUM-10, the Claimant asserts that Energoatom consciously decided not to obtain funding to repay its debts to AMTO. The Claimant argued that as a direct punishment for its choice to obtain more shares in EYUM-10, the Respondent stopped ordering services from EYUM-10, and tried to destroy the company by attempting to obtain an injunction against EYUM-10's assets so that it could not make payments to its workers and service providers. The claimant also claimed denial of justice on the grounds that Ukraine failed to provide EYUM-10 effective means to enforce its bankruptcy judgment, interfered in Bankruptcy proceedings, and actions of the Ukrainian

201 ibid paras $15-24$ 
court that prejudice the Claimant. It prayed for compensation for damages suffered and restoration of AMTO's investment in EYUM-10. ${ }^{202}$

The Respondent's first argument was that the Tribunal did not have jurisdiction under Article 26 of the Energy Charter Treaty based on multiple grounds. It argued that AMTO's shares in EYUM-10 did not qualify as an 'Investment' under the Article 1(6) of the Energy Charter Treaty, as they were not associated with economic activity in the energy sector since EYUM-10's activities consist of merely electric installation, repair, and technical reequipment services to ZAES. Other grounds were: that the Respondent did not consent to arbitration, that the Energy Charter Treaty does not cover actions in the pre-investment period, that the dispute is a trivial commercial dispute between 2 Ukrainian juridical persons and not with the Ukrainian state, that the actual dispute has been exhausted and therefore there is no basis for the present arbitration, among other arguments. It denied that it had breached its obligations under the Energy Charter Treaty on the grounds that any alleged breach took place in the pre-investment period. Furthermore, it claimed that EYUM-10 is a Ukrainian entity, and cannot be given protection meant for aliens. It argued that any breach of this standard requires the unfair treatment reach a minimum threshold of intensity that was absent in this case. It claims that the alleged breaches were based on unsupported allegations. $^{203}$

The Arbitral Tribunal dismissed the claims of the AMTO. It held that the Claimant did have an 'Investment' within the meaning of the Energy Charter Treaty in the energy sector. It held that it did have jurisdiction to hear the case. In regards to claims of denial of justice, the Tribunal held that there was no denial of justice as the Claimant was able to initiate bankruptcy proceedings after it was not included in Energoatom's first 3 bankruptcy proceedings. Furthermore, there was no evidence that the Courts were improperly influenced by the government of Ukraine. The Tribunal further held that resolutions passed by the Ukrainian parliament (such as Resolution No. 765) affected numerous state enterprises, not

202ibid paras 27-31

203ibid para 26 
just the Claimant's, and does not constitute an ad hoc interference by the State. The Tribunal did not find any discriminatory conduct by Ukraine towards the Claimant. ${ }^{204}$

Again it was a case between Europe Cement Investment \& Trade S.A. (as Claimant) and Republic of Turkey (as Respondent), the case was requested by the Claimant on March 6, $2007^{205}$. The Claimant is a Polish registered joint stock company that had allegedly purchased shares in 2 electric power companies, Cukarova Elektrik Anonim Sirketi (CEAS) and Kepez Elektrik T.A.S (Kepez). The company is linked to the Uzan family headed by Cem Uzan. On June 11, 2003 the Respondent terminated Concession Agreements it had signed with the 2 companies in 1998 regarding the generation, transmission, distribution, and marketing of electricity. After which, this claim was filed against the Republic of Turkey. ${ }^{206}$ The Claimant had also filed numerous other claims in relation to shareholdings in CEAS and Kepaz, such as Cementownia, Libananco Holdings Co. Limited, Polska Energetyka Holding S.A., and Cem Uzan at the European Court of Human Rights. ${ }^{207}$ Interestingly, both parties eventually filed discontinuance of the case due to lack of jurisdiction on similar grounds. ${ }^{208}$

The Claimant asserted that it had purchased shares in CEAS and Kepez in May 2003. It claims that in June 2003, the Respondent had unlawfully terminated Concession Agreements between the Turkish Government and CEAS and Kepez. Additionally, it claimed the Respondent raided the premises of CEAS and Kepez, seized documents, intimidated witnesses and harassed employees. In light of this, the Claimant argues that the Respondent had breached its duties under the Energy Charter Treaty (Energy Charter Treaty) under Article 13 by expropriating its property unlawfully. It further made claims under Article 10(1) that the Respondent gives it "fair and equitable treatment". It claimed for damages exceeding $\$ 3,800,000 .^{209}$

\footnotetext{
204ibid paras 101-108

${ }^{205}$ Europe Cement Investment \& Trade S.A. v. Republic of Turkey, ICSID Case No. ARB(AF)/07/2

206 ibid, para 2

207 ibid para 108

208ibid para 81

${ }^{209}$ ibid paras 25-26
} 
After the Respondent filed its prayers for relief, the Claimant switched course. It claimed that it did not refuse the Tribunal's orders to produce authentic share transfer documents; however it is unable to do so unless given a year's time. ${ }^{210}$ Therefore, it requested that the Tribunal dismiss the case "due to our company's inability to show the shares legally acquired by our company". 211

From the outset, the Respondent claimed that the Tribunal had no jurisdiction to hear the case. It requested a suspension of the proceedings until documentary evidence of the 'investment' were produced before the Tribunal and examined for authenticity. It claimed that there was a potential abuse of process, and that proceedings should not continue until the share transfer agreements were produced and verified. Eventually the Respondent submitted its prayer for the relief. It first sought a complete dismissal of the case due to lack of jurisdiction, on the grounds that the Claimant had never proved it had an investment in CEAS and Kepez. Secondly, it claimed that adverse inferences should be drawn against the Claimant for failure to comply with the directions of the Tribunal. Additionally in its Memorial on Jurisdiction, It claimed that the case should be dismissed, that the claim is manifestly ill-founded, and been asserted using inauthentic documents, that the Respondent should be compensated by the Tribunal, and that it should be awarded all costs in the matter. ${ }^{212}$ It also rejected the request for dismissal of the proceedings without prejudice, on the grounds that under Article 49(2) of the Arbitration (Additional Facility) Rules, discontinuance of a case could not occur unilaterally. ${ }^{213}$

The Respondent further asserted that any evidence produced by the Claimant of the share transfer agreements were fraudulent. It argued that the Claimant never actually owned any shares in CEAS or Kepez. It claimed through expert testimony witness that share transfers are subject to many requirements, including approval by multiple government authorities, which were never done. It questioned the Claimant's financial records filed with the Polish

\footnotetext{
${ }^{210}$ ibid para 66

${ }^{211}$ ibid para 66

212 ibid para 63-65

213ibid para 68
} 
courts, which never make any mention of this purchase. These and other inconsistencies were pointed out by the Respondent. ${ }^{214}$

Firstly, the Tribunal considered that both of the parties had applied for discontinuance of the case but on different grounds. The Claimant admitted it could not produce the share transfer agreements as ordered in time for the Arbitration, and that therefore the proceedings should be discontinued. The Respondent argues that the Tribunal should discontinue the proceedings because the Claimant never was able to prove that it had an 'investment' as defined under the terms in Article 26(1) of the Energy Charter Treaty. The Tribunal concluded that despite both agreeing on the outcome of the case (dismissal), that is not to be treated as mutual consent of discontinuance of the present proceedings, as they had different grounds for doing so. ${ }^{215}$

The Tribunal agrees on the grounds of the Respondent that it did not have jurisdiction to hear the case on the grounds that the Claimant never produced any evidence of an 'investment' as required to initiate arbitration proceedings under the Energy Charter Treaty. It awarded full costs plus expenses $(\$ 3,907,383.14)$ to the Respondent. ${ }^{216}$

In the case of Plama Consortium Limited (as the Claimant) and Republic of Bulgaria (as the Respondent), Nova Plama was a 100\% Bulgarian state owned company which owned an oil refinery from 5 September 1995. Under the First Privatization act, it was sold to EuroEnergy Holding ("EEH"). ${ }^{217}$ Subsequently, EEH, with approval of the Bulgarian Privatization Agency, sold its shares to the Claimant ("PCL") on December 18, 1998 under the Second Privatization Act. The owner of PCL was a Mr. Vautrin. Within a year of the transfer to PCL, the company faced problems and initiated bankruptcy proceedings. The bankruptcy case was dismissed by the Bulgarian Supreme Court of Cassation. It was re-opened by the Pleven District Court in April 2006 and Nova Pluma underwent liquidation on 18 June 2007.218

\footnotetext{
214ibid paras 92-95

${ }^{215}$ ibid para 121

216ibid para 186

${ }^{217}$ Plama Consortium Limited v. Republic of Bulgaria, ICSID Case No. ARB/03/24

218ibid paras 56-65
} 
The Claimant argued that the Respondent created numerous and grave problems for Nova Pluma, leading to its bankruptcy. It argued that the Respondent violated Article 10(2) of the Energy Charter Treaty by failing to provide fair and equitable treatment, failing to create stable, equitable, favorable, and transparent conditions for the Claimant's investment, unreasonable and discriminatory measures, and actions amounting to expropriation. ${ }^{219}$

The Respondent denied the above claims and firstly claimed that the Claimant, PCL, was actually a fictitious entity, misrepresented to the Bulgarian Privatization agency by Mr. Vautrin. Therefore, the contract between the Claimant and Respondent was void ab initio. It further claimed that it is entitled to deny advantages to Nova Pluma by virtue of Article $17(1)$, which allowed each contracting party to deny advantages if that entity had no substantial business activities in the Area of the Contracting Party in which it was organized. ${ }^{220}$

The Respondent argues that the ICSID did not have jurisdiction to hear the case as it had exercised its right under Article 17(1) to deny advantages of the Energy Charter Treaty to the Claimant. It argued that there was no evidence of ownership, control, or substantial business activity by a member of the Energy Charter Treaty within Bulgaria. This denies the Claimant to pursue dispute settlement under the Energy Charter Treaty. The Respondent also argues that it did not consent to jurisdiction by the MFN principle, because that obligation only applies in an agreed sphere of relations. Due to the lack of clarity of the identity of the Claimant, there was no real agreed sphere of relations for which Bulgaria needed to give most favored treatment to. Whether or not there was ownership or control by the Claimant was an issue not decided on, pending other cases related to the Claimant. The Arbitral Tribunal held that invoking Article 17(1) of the Energy Charter Treaty was not relevant to the issue of jurisdiction to hear the case. ${ }^{221}$

As far as jurisdiction, The Claimant, although not having any substantial business activities in Cyprus where it is incorporated, was ultimately owned by Mr. Vautrin, a French national, whose country is a party to the Energy Charter Treaty. Therefore it had jurisdiction to hear the case. In regards to the misrepresentation by the Claimant, the Arbitral Tribunal

\footnotetext{
${ }^{219}$ ibid para 73

${ }^{220}$ ibid paras $85-87$

${ }^{221}$ ibid paras $89-91$
} 
held that the Claimant, Mr. Vautrin, failed to prove that PCL had control over the Investment, as it was actually in essence controlled by Mr. Vautrin through various other entities that were all owned by him. The Bulgarian Privatization agency was relying on the financial stability of the consortium that PCL apparently was financed by, however that contention was never rebuked by Mr. Vautrin. The Arbitral Award held that the Respondent did not have the right to deny advantages under Article 17(1). However, the Award could not give protection of the Energy Charter Treaty to the Claimant because he was a fraudulent contracting party, it would have been against the principles of International Law as well as Bulgarian Law to entitle the Claimant to these protections. In essence, the Arbitral Tribunal ruled in favor of the Respondent, pending other litigation in Switzerland by other creditors. 222

Another important case was between Azpetrol International Holdings B.V. Azpetrol Group B.V. Azpetrol Oil Services Group B.V. (as Claimants) and the Republic of Azerbaijan (as Respondent). ${ }^{223}$ The claimants were a company registered in Netherlands but affiliated with a national in Azerbaijan. The respondent is the Republic of Azerbaijan. On July 13, 2006 the claimants requested for arbitration by the ICSID on the grounds of breach of the Energy Charter Treaty in violation of Article 13 as to expropriation by the respondent, as well as Articles 10, 14, and 22. After some delays, on July 1, 2008 a witness, who was a director of the Claimants, admitted in testimony to bribing officials in Azerbaijan for protection of certain unnamed individuals. Thereafter, both parties filed for an adjournment, seeking a procedural standstill to the arbitration. ${ }^{224}$

Afterwards, a series of exchanges of emails between the Claimant and Respondent's solicitors indicated that they intended to settle the matter on a "drop hands" basis, which essentially means the case is discontinued without either party paying costs to the other. Eventually on December 16, 2008 counsel for the Respondent sent a comprehensive email detailing the counter offer to settle. The terms were that 1) the Claimant must withdraw the

\footnotetext{
${ }^{222}$ ibid paras 279-284

${ }^{223}$ Azpetrol International Holdings B.V., Azpetrol Group B.V. and Azpetrol Oil Services Group B.V. v. The Republic of Azerbaijan, ICSID Case No. ARB/06/15

${ }^{224}$ ibid para 6
} 
claim, 2), Nuisance payment to be made to the claimant of $\$ 1500,3)$ No admission of guilt or liability, 4) Azerbaijan must be able to disclose the terms of the settlement to the public, and most importantly 5) The settlement is full and final settlement of any claim. ${ }^{225}$ Eventually on December 192008 counsel for the Claimant agreed to the counter offer after discussing it with the Claimant. Afterwards, several email exchanges occurred which the claimants sought to go reverse the acceptance of the counter offer. The Respondent's filed for conclusion and discontinuance of the arbitration as a binding settlement had been reached, while the claimant's filed a counter memorial. ${ }^{226}$

The Claimant's argued that the arbitration should not be discontinued as the settlement reached was 'an agreement in principle' and not legally binding. They argued that (in accordance with English law of contracts) there was no: Intention to create legal relations, meeting of minds on anything other than a standstill agreement, incomplete offer and acceptance, and no communications meaning to intend a binding agreement. ${ }^{227}$

The Respondent's claimed that the exchange of emails was a binding legal document and that the case was settled after the offer and acceptance contained in the emails. ${ }^{228}$

The Arbitral Tribunal discontinued the arbitration. As far as the issue of whether or not the exchange of emails constituted a final binding agreement, the Court considered the claimant's arguments. First it looked at the language of the most conclusive e-mail, that of December 16, and found that the words "offer of settlement", and "we hereby accept the offer" constitute a final binding settlement rather than a settlement subject to further arbitration. ${ }^{229}$ Secondly, it looked at whether there was an intention to create legal relations. The claimant argued that the agreement was only 'an agreement in principle' not beyond the conclusion of an agreement to a standstill. The Tribunal concluded that if that were the case, it must be evidenced in the exchange of emails. No such wording was found in the exchange. ${ }^{230}$ Thirdly, is whether there was a meeting of minds. The Tribunal used the ob-

\footnotetext{
${ }^{225}$ ibid para 28 , point 5

226ibid para 11

227ibid para 76

228ibid para 42

${ }^{229}$ ibid para 70

${ }^{230}$ ibid para 76
} 
jective test of whether "a reasonable observer would conclude that the exchange of emails on 16-19 December would conclude that the parties intended to conclude a binding agreement to settle the proceedings". On this issue, the Tribunal sided with the Respondent's counsel that he intended to make a binding agreement to settle the case. ${ }^{231}$ Lastly, the Tribunal considered whether or not the terms of the agreement were incomplete. The Tribunal concluded that terms of the agreement such as a provision on governing law, a provision on dispute resolution, and a provision regarding the witness's protection from prosecution, were not indispensable terms. They did not consider those sorts of terms as perquisites to a binding agreement. ${ }^{232}$

It examined the arguments of the Claimant, but found that there was intention to create legal relations, a meeting of minds, and a binding legal agreement. They looked particular at the wording of the email exchanges, to which no 'agreement in principle' was explicitly stated. In other words, the wording was definitive. It therefore concluded that the proper procedure was to dismiss the case on the basis that there was no 'legal dispute' as required by Article 25(1), nor dispute under Article 26(1), and therefore had no jurisdiction to hear the case. It rendered its award accordingly to dismiss the case ${ }^{233}$. The Tribunal was bound to follow Rule 43(1) of the ICSID Arbitration rules that it should discontinue the proceedings if the parties agreed to a settlement. ${ }^{234}$

Furthermore there was a case between Cementownia "Nowa Huta" S.A. (as Claimant) and Republic of Turkey (as Respondent). ${ }^{235}$ CEAS and Kepaz are both electric generation and transmission utility companies. The Turkish government had some shares in both companies. In the 1950 's they were given concession rights for generation, transmission, and distribution of electricity. Eventually in 1992, the Turkish government decided to privatize their remaining shares by offering them to public bidding through a tender process. The

\footnotetext{
${ }^{231}$ ibid para 81

232ibid para 84

233ibid para 105

${ }^{234}$ ibid para 103

${ }^{235}$ Cementownia "Nowa Huta" S.A. v. Republic of Turkey, ICSID Case No. ARB(AF)/06/2
} 
winning bidders were Rumeli Elektrik Yatirim which was owned by the billionare Uzan family, who slowly increased their shareholding in the company. ${ }^{236}$

In 1998, new Concession agreements were entered into which allowed Rumeli Elektrik Yatirim to continue its operations but the facilities would remain State property of the Turkish government, and would revert to the state at the end of the Concession period. In Feb 2001, the Turkish government passed a new Electricity Market Law which effectively rendered Kepez and CEAS to do business, and instead would have them give up their operations to Turkish Electricity Joint Stock Company. This was disputed in the Turkish Courts as well as parliament. Nevertheless, the Turkish government sent multiple warnings to the CEAS and Kepez that they needed to adhere to the conditions set out by the Electricity Market Law, or otherwise face adverse actions by the Turkish government. These warnings were not followed by the companies. ${ }^{237}$

The Turkish government pressured CEAS and Kepaz to transfer ownership of its companies to the state owned electricity company in early 2003. On May 302003 The Claimants allegedly purchased shares from Rumeli Elektrik Yatirim. On April 15, 2008 the premises of CEAS and Kepaz were raided and their assets were seized, as well as employees removed. This Arbitration case was filed in addition to other similar cases filed by other companies controlled by the Uzan family, which further caused suspicion. ${ }^{238}$

The Claimant argues that the Respondent violated Articles 10(1) of the Energy Charter Treaty which provides investors with constant protection and security, and without unreasonably or discriminatory treatment. They also claimed under Article 13 in regards to expropriation by the Turkish government of the assets of the Claimant. Strangely, the Claimant agrees with the Respondent that the ICSID lacks jurisdiction to hear the case. It responded to the Respondent's claim for discontinuance of the case by seeking that the Tribunal dismisses the case due to the Claimant's inability to produce authentic documents showing the share transactions. ${ }^{239}$

\footnotetext{
236ibid para 8

237ibid para 10

238ibid para 16

239ibid paras $105-108$
} 
First and foremost, the Respondent rejected the jurisdiction of the ICSID to hear the case. The grounds being that the Claimant knew it did not own assets in the CEAS and Kepez, that it did not record the share transactions until after 3 years after it allegedly took place, that the shareholding of that company is uncertain, and that it is part of a greater effort by the Uzan family to "assert baseless claims" before various Tribunals. ${ }^{240}$ The Respondent argues that Cementownia is a front company for fraud and abuse and to retain its assets in the face of Turkish laws. It argues that the share transactions were not actually conducted and that no evidence was produced that shares were exchanged. They claim that Kemal Uzan, of the Uzan family, used the Claimant to shield its assets and protect them from being expropriated by the Turkish government. It seeks from the Tribunal a declaration that the claim is "manifestly ill-founded, and has been asserted using inauthentic documents". 241

The Arbitral Tribunal found that the Claimant's conduct through evidence shows that the transferring of shares was fraudulent and "a transfer of national economic interests to a foreign company in an attempt to seek protections under a BIT". The Tribunal found that the circumstances in which the transactions allegedly occurred were suspicious and inconsistent. Transactions were carried by phone conversations. Purchasing shares without reporting to the Ministry and following the procedure were allegedly carried out. Financial statements by the Claimant did not mention the purchasing of these shares, despite the Claimant mentioning other transactions in the same fiscal year. ${ }^{242}$ In other words, the Claimant was trying to transfer assets to gain jurisdiction to the Energy Charter Treaty, but later realizing it would not win its case, tried to absolve itself from any liability imposed by the Tribunal. The Tribunal followed the principle of "cost follows the event", which makes the losing party bear all of the costs. It followed this principle on the grounds that the Claimant has filed a fraudulent claim, failed on all its requests of relief, delayed the arbitration proceeding which incurred more costs, and never signed a Custody Agreement despite

\footnotetext{
240ibid para 151

241 ibid para 108

242ibid para 129
} 
being advised to. ${ }^{243}$ The Tribunal awarded the respondent all of its costs to the amount of USD4.9 million for filing a fraudulent claim at the ICSID. ${ }^{244}$

Also the case between Mohammad Ammar Al-Bahloul (as Claimant) and Republic of Tajikistan (as Respondent), ${ }^{245}$ the Claimant is an Austrian citizen and investor with a market trading business in Austria. The Respondent is the government of the republic of Tajikistan. In June 1998, the Claimant traveled to Tajikistan at the request of the Tajikistan Prime Minister and offered several investment projects in the oil and gas sector. He signed an oil and gas exploration agreement with the State Committee, which he was to provide at his own risk, the expenses necessary for oil and gas exploration in the Kashkakum and Alimtay areas. The agreement gave the claimant to carry out geological and natural resource exploitation works which could be examined by Austrian Party authorities, ${ }^{246}$

In March 2000, a new approach was taken and the Claimant and Respondent set up new agreements whereby they would set up joint venture entities for oil and gas exploration; the claimant would have a majority share and control. The agreements eventually materialized into a company Petroleum SUGD, in which both parties had to pay their investments in full. No exploration activity was eventually carried out as the government Ministry of Energy was not issuing licenses for certain areas of Tajikistan in time. The Claimant eventually stopped investing and sealed its wells. The Government complained that the Claimant was doing work but at unsatisfactory levels, and that the Claimant had no paid its full authorized capital as stated in the agreement. The Government then issued decrees that effectively reduced the shareholding of the Claimant's company involved in the joint venture Vivalo. The Claimant, not receiving the licenses it sought for 6 months, filed for arbitration after several meetings and hearings. ${ }^{247}$

The Claimant argued that the Respondent had breached Article 10(1), (7), and Article 13 of the Energy Charter Treaty (Energy Charter Treaty). Specifically, the section of the provi-

\footnotetext{
243ibid para 177

244ibid para 154

${ }^{245}$ Mohammad Ammar Al-Bahloul v. The Republic of Tajikistan, SCC Case No. V (064/2008)

246ibid paras 58-61

247ibid paras 73-76
} 
sion that obliges nations to provide; fair and equitable treatment (FET), constant protection and security, and not be subject to unreasonable or discriminatory measures. It also claimed that the failure to grant licenses on time amounted to expropriation by the Respondent of the Claimant's assets. ${ }^{248}$

The Claimant claims that the FET standard was breached by several actions by the government of Tajikistan, namely its inconsistency and lack of transparency in issuing licenses to the Claimant, its failure to issue licenses which were legitimate expectations of the Claimant, and failure to observe due process in Tajiki courts. It sought relief from the Tribunal, that the Respondent breached provisions of the Energy Charter Treaty and Tajiki Law. It also sought the necessary licenses from the Tajiki government, restore shareholding of Vivalo, and compensatory damages amounting over USD 13 million from the 2 agreements signed for both oil exploration contracts. Additionally, it sought USD 73 million for compensatory damages of the joint venture firm Petroleum SUGD. ${ }^{249}$

The Tribunal considered the allegations behind the breaches of the FET standard. The primary claim of the Claimant was based on its assertion that the Government of Tajikistan failed to issue licenses to the Claimant within 6 months, which made Petroleum SUGD (the joint venture) unable to conduct business in the area. However, the evidence never showed that there was any delay in issuing licenses. There was evidence of letters to the Tajiki government requesting licenses, but there is no evidence of any application for any licenses that follow the legal requirements. Furthermore, the Respondent on December 20, 2002 did in fact issue licenses that were evidenced to the Tribunal. It appears the Chairman of Petroleum SUGD did not know whether or not the Government of Tajikistan had issued licenses to the company, but rather assumed they did not. ${ }^{250}$

As far as the 2000 oil and gas exploration agreements, although they became the basis for which the Claimant could invest in Tajikistan in the area of oil and gas exploration, there is no evidence that the Claimants actually incurred any expenses after the Agreements were signed. There was only some work done in 1 area in 1998, to which licenses were duly issued, and that work stopped in 2000. Furthermore, there was no mention in those agree-

\footnotetext{
248ibid para 98

${ }^{249}$ ibid para 99

250ibid paras $190-193$
} 
ments of the subsequent Baldjuvon joint venture, to which the Claimant claims they were awaiting licenses for. Therefore, there is no evidence that the Respondent failed to meet the legitimate expectations of the Claimant's business. ${ }^{251}$

In regards to the breach of due process, the Tribunal found that the SUGD Economic Court scheduled a hearing in 2003 and heard the case without the presence of the defendant. The Chairman of Petroleum SUGD was in the Courthouse but gave no explanation as to why he didn't attend the hearing. Therefore, there was no breach of due process. In conclusion, the Tribunal found that the Respondent had breached its obligations under Article 10(1) by not issuing Licenses to carry out solely and exclusively geological exploration only for the 2000 Agreements, but all other claims were denied. ${ }^{252}$

Later it was a case between Lmian Caspian Oil BV "LCO” (as Claimant No. 1) and NCL Dutch Investment BV "NCL" (as Claimant No. 2) against Republic of Kazakhstan " $R O K$ " ${ }^{253}$ The background of the case is that the Respondent's granted to a company named " $X$ " a license to exploit hydrocarbons in a certain area called the Liman Block in Kazakhstan. X was controlled $99.9 \%$ by Y, and the remaining to P and Q. In October 2002, $\mathrm{X}$ assigned its rights ("the Assignment Agreement") under the license to LCO. P and Q then filed a suit in the local courts of Kazakhstan, and sought invalidation of the Assignment Agreement on the grounds that it was transferred without their knowledge or consent in breach of Kazakhstani Law No 281-1 on Joint Stock Companies (“JSC Law”). In 2004, the Courts ruled in favor of $\mathrm{P}$ and $\mathrm{Q}$, invalidated the Assignment Agreement, and returned the shares back to X. By that time, X was controlled by another company, M, which joined these proceedings. $X$ tried appealing the Courts decision, but in May 2005, those appeals were dismissed. Claimant No. 2 owned $90 \%$ of LCO, while the rest of LCO was owned by Y whom arranged the Assignment Agreement.

The Claimants argued that the Respondent's through denying its appeal in Court and ordering the shares to be returned to X, had violated Article 13(1) of the Energy Charter Treaty by expropriating its property. It further argued that there was a denial of justice against the

\footnotetext{
${ }^{251}$ ibid paras 206-207

${ }^{252}$ ibid 97-98

${ }^{253}$ Liman Caspian Oil BV and NCL Dutch Investment BV v. Republic of Kazakhstan, ICSID Case No. ARB/ $07 / 14$
} 
Claimant due to the decisions of the Court in breach of its obligations under Article 10(1) of the Energy Charter Treaty. The Claimant asserts that they were not treated up to the 'fair and equitable' standard. ${ }^{254}$ It claimed that the license was obtained by LCO by fraudulent misrepresentations to the Ministry of Energy through $\$ 3,000,000$ in bribes. ${ }^{255}$

*This case brief was prepared using the only available Award published online, which contains only excerpts from the full Award. Full and exact arguments cannot be determined but only inference.

The Respondent argued that there was no denial of justice against the Claimant's in respect to court decisions made under Kazakhi law. It claimed that it had followed its domestic law, which includes laws such as Article 80 of the JSC Law, forbidding major transactions to occur without following the proper procedure, and allowing the invalidation of any agreement that does not follow the procedure. ${ }^{256}$ It also claimed that under Article 17(1) it had the right to deny advantages given to foreign investors if they breach their obligations under the Energy Charter Treaty. ${ }^{257}$

Firstly, the Tribunal decided that on the merits, it did have jurisdiction to hear the case as both sides had prima facie claims to be tried. On the issue of whether it can overturn the Kazakhi Court's decision, it reminded the parties that the ICSID is not an appellate body, and does not correct errors of domestic procedural or substantive law. To determine if there was a denial of justice, the Court referred to Mandev v United States of America, which stated that the test of denial of justice "Is not whether a particular result is surprising, but whether the shock or surprise occasioned to an impartial tribunal leads, on reflection, to justified concerns as to the juridical impropriety of the outcome...". ${ }^{258}$ Thus, denial of justice can only be claimed if there are major procedural errors committed by the Court, rather than in substantive law. ${ }^{259}$ It emphasized that a judicial act can never be considered to be a breach of that party under Article 10(1) of the Energy Charter Treaty. It also empha-

\footnotetext{
${ }^{254}$ ibid para 268

${ }^{255}$ ibid para 438

${ }^{256}$ ibid para 58

257ibid para 55

258ibid para 275

259ibid para 279
} 
sized that not only is it not an appellate body on national law, but that it only hears matters related to breaches of the Energy Charter Treaty. ${ }^{260}$

It denied that the Kazakhi courts acted in a way that was characterized as being "arbitrary, grossly unfair, unjust, idiosyncratic, or involving a lack of due process". It also decided that despite corruption being very hard to prove, no credible or valid evidence of the $\$ 3,000,000$ bribe through financial records was brought by the Claimant to support the allegation that the Assignment Agreements were a result of an illegal bribe or transaction. ${ }^{261}$ In regards to expropriation, the Tribunal concludes, citing the case of Azinian v Mexico, that a government authority cannot be punished for acting in accordance with the decisions of its courts. Therefore, the order of transfer to $\mathrm{X}$ was not to be disturbed by the Tribunal. ${ }^{262}$

Finally, the Tribunal considered the costs. It decided that since the Claimant had won the jurisdictional phase of the case, and the Respondent won the merits part of the case, that both parties could share the cost equally, neither side won their claim completely, nor lost it completely either. ${ }^{263}$

It was another case between Vattenfall Europe Generation AG (as Claimants) and Federal Republic of Germany (as Respondent). ${ }^{264}$ The Claimants were Vattenfall AB, an energy company registered in Switzerland, along with Vattenfall Europe AG and Vattenfall Europe Generation AG, which were companies registered in Germany. The Claimant was an owner of a coal-fired power plant in Hamburg called the Moorburg Coal Power Plant. Beginning in 2004, the claimants were in negotiations with the local Authority for Urban Development and Environment of Hamburg ("BSU") acting on behalf of the Government, to authorize building a dual-block power plant to supply district heating to the city of Hamburg. The Authority was run by the Green Party, which generally opposes building environmentally unfriendly buildings and facilities. In order to construct the power plant, German law

\footnotetext{
260ibid para 346

261ibid para 422

262ibid para 433

263ibid para 466

${ }^{264}$ Vattenfall AB and others v. Federal Republic of Germany, ICSID Case No. ARB/12/12
} 
required the issuance of various permits at each stage of construction. ${ }^{265}$

The "emission control permit" and "water permit" are of particular importance. The issuance of these permits was delayed due to local criticism of the building of the plant. By September 2008, Vattenfall had worked to comply with all of the requirements imposed by the BSU and subsequently these permits were granted. However, Vattenfall claims that the permits were heavily restricted and that 'the effects of these limitations would be so severe that the plant would have to be shut down for weeks during summertime. Restrictions of this magnitude have not been even remotely mentioned, discussed, or proposed during the administrative procedure.' Therefore, the Claimants filed suit against the Respondents under Article 10 of the Energy Charter Treaty for breach of the fair and equitable treatment standard ("FET"). It claimed that the delays in granting the permits, as well as additional requirements imposed on it, constituted an indirect expropriation in violation of Article 13 of the Energy Charter Treaty. It claimed 1.4 billion Euros as compensation. ${ }^{266}$

Rather than going through full arbitral proceedings, the parties decided to suspend proceedings in March 152010 and entered a final and binding mechanism under ICSID Arbitration Rule 43(2) to settle their dispute. The agreement is signed and dated August 17, 2010 and contains 4 conditions: 1. A court settlement agreement is agreed upon between Vattenfall Europe Generation AG and the Free and Hanseatic City of Hamburg which terminates the proceedings regarding the water use permit. 2. A modified water use permit to be issued to the Claimant and declared immediately enforceable. 3. A confirmation in writing by the Free and Hanseatic City of Hamburg that Vattenfall is free from any undertakings to set up district heating pipelines to the city of Hamburg, and 4. Any permits deemed enforceable by the above agreements shall also be deemed to be fulfilled if Vattenfall fails to comply with its obligations stated in the agreement. Upon the signing of this agreement, the parties under Article 3 agree to suspend proceedings indefinitely and neither Party may resume proceedings unilaterally except by Article 4 through joint application. The parties admit no admission or acknowledgment of any liability or wrongdoing whatsoever.

\footnotetext{
${ }^{265}$ F. Jacur, 'The Vattenfall v. Germany Disputes: Finding a Balance Between Energy Investments and Public Concerns' $2<\mathrm{http}: / /$ www.academia.edu/18512478/The_Vattenfall_v._Germany_Disputes_Finding_a_Balance_Between_Energy_Investments_and_Public_Concerns $>$ accessed $25 \overline{\text { January }} 201 \overline{7}$ 
The following case was the AES Summit Generation Limited with AES-Tisza Eromu Kft. (as Claimants) vs Republic of Hungary. ${ }^{267}$ The first claimant, AES Summit, was a UK based company which owned the $2^{\text {nd }}$ claimant, AES Tisza, which was a Hungarian based company. The respondent was the Republic of Hungary. ${ }^{268}$ In 1995, Hungary privatized its energy sector including state-owned power stations. On July 4, 1996 a Purchase and Sale Agreement ("PSA") was signed between companies owned by the Respondent, APV and MVM, with the Claimant, AES Summit, whom subsequently purchased the $2^{\text {nd }}$ Claimant's company, AES Tsiza. AES Tsiza owned a power station named Tisza II, and 2 other power stations named the Borsod and Tiszapalkonya power station. Pursuant to the PSA, Hungary was obligated to extend terms on the existing PSA's on the Tisza II power plant, and enter into new PPA's regarding the Borsod power station. In return, the first Claimant was to modernize the Tisza II power plant, and construct a new power plant at Borsod. ${ }^{269}$

The Respondent then failed to extend the PPA's as it was obliged to, and subsequently entered into Arbitration with the Claimant. The conclusion of this arbitration was settled by a Settlement Agreement in December 2001, and included a "waiver of sovereign immunity clause", which essentially treats the entire agreement as a private and commercial transaction, rather than a governmental act. ${ }^{270}$ It also included a clause in the original Tsiza II PPA, stipulating that if a change in law occurs before January 1, 2007 or if Hungary enters the EU, the parties shall enter a negotiating period to make changes the Agreement, and if no change can be agreed upon, either party could terminate the agreement and compensate should be made to the Generator. ${ }^{271}$

In January 1, 2004, the Hungarian government issued 2 Price Decrees, which essentially regulated the price of energy. After this, the Claimant requested for Arbitration on July 9, 2007.272

\footnotetext{
${ }^{267}$ AES Summit Generation Limited and AES-Tisza Erömü Kft v. The Republic of Hungary, ICSID Case No. ARB/07/22

268ibid para 3.1

${ }^{269}$ ibid para 4.4

270ibid paras $4.7-8$

${ }^{271}$ ibid para $4.10(\mathrm{c})$

272ibid para 3.1
} 
The Claimant's claim that Hungary violated its obligations under the Energy Charter Treaty by its implementation of Pricing Decrees under Article 10(1), 10(7), and 13 of the Energy Charter Treaty. ${ }^{273}$. It claimed that the Respondents had breached its obligation under the FET standard, subjected the Claimant to unreasonable and discriminatory measures, breached obligations of national treatment, and most favorable nation treatment, failed to provide constant protection and security, and expropriated its assets. ${ }^{274}$

As far as the FET claim, the claimant argued that Hungary promised not to interfere or frustrate the Claimant's PPA, but then caused MVM not to fulfil its contractual commitments to AES Tisza. This led to the further argument that it had failed to act in good faith during the negotiations in 2001. It argued that the Respondents failed to provide stable, equitable, favorable and transparent conditions for which it could legitimately rely on. ${ }^{275}$ It also argued that the Respondent acted arbitrarily by introducing and amending the 2006 Electricity act to the disfavour of the Claimant. ${ }^{276}$

The Respondent's position was that the Claimant could not have had legitimate expectations that the prices would change by decree, that its decisions were not arbitrary, that it acted at all times in good faith, and that none of the price decrees violated any due process. ${ }^{277}$ It asserted that due to Hungary joining the EU, the Claimant should have expected that there would be changes in laws that would affect the PPA, as there was no stabilization clause in the 2001 PPA. ${ }^{278}$

It also argued that it did not act arbitrarily as the decrees were made after pressure by the European Commission to renegotiate PPA's in the energy generation sector, and that the Claimant's refused renegotiation of the PPA's. ${ }^{279}$ In regards to the claim of legitimate expectations, the Tribunal concluded that the Claimants could not have been legitimately ex-

\footnotetext{
273ibid para 4.1

${ }^{274}$ ibid para 5.1

${ }^{275}$ ibid paras $9.1 .2-4$

276ibid para 9.1.7

277ibid para 9.2.1

278ibid para 9.2.7

279ibid para 9.2.16
} 
pected pricing regimes not to resume under the 2001 PPA. ${ }^{280}$ In regards to the breach of the FET standard under Article 10(1), the Tribunal found that there was no breach of the FET standard, as the 2001 PPA did take notice that a change in law might occur, especially with Hungary joining the EU. ${ }^{281}$

As far as the unfair and inequitable treatment, the Tribunal concluded that although not the best law, Hungary's decrees and legislative acts were within the tolerable legislative and regulatory behavior and therefore was not unfair or inequitable. ${ }^{282}$

As far as discriminatory treatment, the Tribunal found that there was no discriminatory treatment, as the Pricing Decrees were reached using the same methodology and not specifically targeting any particular energy generator. ${ }^{283}$

Since there was no unfair or discriminatory treatment, it also concluded that the Respondent's did not breach its Energy Charter Treaty obligation to provide MFN treatment. ${ }^{284}$ The Tribunal dismissed the claim of the Claimant's and awarded costs equally among the parties. ${ }^{285}$

The next case was between Khan Resources Incorporated Khan Resources B.V, CAUC Holding Company Ltd. (as Claimants) against Republic of Mongolia MonAtom LLC (as Respondents). ${ }^{286}$ The Claimants were Khan Resources Inc, a company based in Canada, Khan Resources B.V., a company based in the Netherlands, and Central Asian Uranium Holding Company Ltd. ("CAUC"), a company incorporated in the British Virgin Islands (para 1, pg. 1. The Respondents were the Government of Mongolia and MonAtom LLC, a company incorporated in Mongolia. ${ }^{287}$

\footnotetext{
${ }^{280}$ ibid para 9.3.26

281ibid para 9.3.41

282ibid para 9.3.73

283ibid para 10.3.47

${ }^{284}$ ibid para 12.3 .2

285ibid para 16.1

${ }^{286}$ Khan Resources Inc., Khan Resources B.V., and Cauc Holding Company Ltd. v. The Government of Mongolia, UNCITRAL

287ibid para 2
} 
In mid-1995, CAUC commenced a joint venture with a Mongolian state owned company Mongol-Erdene, and WM Mining Inc, for a uranium exploration and extraction project in the Dornod region in Northeastern Mongolia. ${ }^{288}$ Eventually, Khan Canada acquired all the shares in the joint venture to form CAUC Holding Company Ltd, while the state-owned shares were transferred to the Government of Mongolia between 2004-and 2009. ${ }^{289}$ Between 1998 and 2005, CAUC applied and received exploration licenses from the Mongolian government for the exploitation of radioactive materials. For the Dornod project, Khan secured financing of USD 31.3 million in 2006-2007 for development of this project. ${ }^{290}$

The Claimants then commenced drilling and exploration projects, and conducted feasibility studies to ascertain the value of the mining area. ${ }^{291}$ However, the Respondents maintained that The Claimants never really wanted to bring the project into operation, but merely wanted to increase the value of the project so it could sell its share as profit. ${ }^{292}$ They assert that no mining activities were carried out by the Claimants, and that the only activity was information gathering. ${ }^{293}$

In 2007, the Claimants attempted to convert their Exploration licenses into Mining licenses but the decision on this was deferred due by the Mongolian Mineral Resource and Petrolium Activity Authority due to investigations that reported violations of Mongolia's Radiation Protection and Safety Law, and also violations of the joint venture agreement regarding the timing of feasibility studies. ${ }^{294}$

By July 2009, the MRAM suspended the mining license of the Claimants, citing failure to remedy legal violations. ${ }^{295}$ Meanwhile, the Claimants were pursuing their suspension of Mining licenses in the Mongolian Administrative Court all the way up to the Supreme

\footnotetext{
288ibid para 44

289ibid paras 47-48

${ }^{290}$ ibid para 54

${ }^{291}$ ibid paras 59-60

${ }^{292}$ ibid para 66

293ibid para 67

${ }^{294}$ ibid paras $71-75$

${ }^{295}$ ibid para 79
} 
Court. By 2012, the Respondents informed the Claimant that their mining licenses would not be re-registered.

The Claimant's contended that the Respondents unlawfully deprived them of their investments, in the form of Mining and Exploration licenses, as well as contractual rights from their joint venture agreements. ${ }^{296}$ The Claimants brought claims that the Respondents had violated Article 13 of the Energy Charter Treaty for expropriation, the umbrella clause in Article 10(1), and also the fair and equitable treatment standard (FET) also in Article 10(1). ${ }^{297}$

The Respondents argued that it had not breached its obligations by not re-registered licenses as it had followed the Nuclear Energy Law of Mongolia, 2009. ${ }^{298}$ That Act was enacted due to its sovereignty of the country's mineral resources, and the dangers posed by mining radioactive materials. That Act was drafted with the help from the International Atomic Energy Agency (IAEA) and required exploration licenses to be re-registered in 2009. Their contention was that this measure applied generally to any company in the industry, and not directed at the Claimant's alone. Furthermore, the Respondent's contended that the licenses were not re-registered as the Claimant had repeatedly breached Mongolian law and had not rectified the breaches. ${ }^{299}$ As far as expropriation, the Respondents contend that international law does not oblige States to compensate foreign investors if the law enacted is non-discriminatory, and has a bona fide legitimate purpose. ${ }^{300}$

The Tribunal concluded that the Respondents had breached their obligations towards the Claimants under Article 10(1) of the Energy Charter Treaty in relation to the Mining and Exploration licenses. ${ }^{301}$ The Tribunal analyzed the Nuclear Energy Law of Mongolia, and found that the Act did not make provision for the re-registration procedure, but rather the Claimants would have had to be registered under the Act before needing to be re-regis-

\footnotetext{
${ }^{296}$ ibid para 101

297ibid para 106

298ibid para 197

${ }^{299}$ ibid paras 203-205

300ibid para 209

${ }^{301}$ ibid para 366
} 
tered. It therefore could not have been invalidated ${ }^{302}$. Furthermore, a legal decision on the status of the re-registration was not properly conducted by the NEA, which constituted a breach of due process. The NEA furthermore lacked the authority to invalidate licenses that were registered under prior mineral laws. ${ }^{303}$ In regards to breaches of Mongolian law, the 2009 and 2010 reports that claimed breaches of Mongolian law that were breached had not been seen by the Claimants prior to the arbitration, and thus were treated cautiously The Tribunal thus ordered the Respondents pay to the Claimants USD \$80 million as compensation for the breaches under the Energy Charter Treaty. It also awarded interest, and reimbursement for the Claimants share of the arbitration costs amounting to USD \$9 million. ${ }^{304}$

Another important case was between Libananco Holdings Co. Limited (as Claimant) and Republic of Turkey (as Respondent). ${ }^{305}$ The Claimant was a limited liability company domiciled and registered in Cyprus. The Respondent was the Republic of Turkey. In 1992, the Turkish government offered to sell its shares in ÇEAŞ and Kepez, which were 2 successful electricity generation and transmission companies. The winner of that government tender was Rumeli Elektrik Yatirim ("Rumeli Elektrik") which was a company owned by the Uzan family, who had a combined net worth of $\$ 1.6$ billion and over 130 business operations in many sectors. ${ }^{306}$

After obtaining the shares, Rumeli Elektrik continued to increase its shareholding over the years, eventually becoming the majority shareholder by the mid 1990's. In 1998, the Turkish government passed a law which as a result, required ÇEAŞ and Kepez to replace their concession contracts with new ones. They were given the right to operate for another 60 years..$^{307}$

\footnotetext{
302ibid para 361

${ }^{303}$ ibid para 364

304ibid para 320

${ }^{305}$ Libananco Holdings Co. Limited v. Republic of Turkey, ICSID Case No. ARB/06/8

306ibid paras $88-89$

307ibid paras 91-92
} 
Subsequently in 2002, the Claimant alleges that it purchased shares in ÇEAŞ and Kepez through acquiring Libananco Limited Holdings, which was also owned by the Uzan family. The Uzan family claims that this was due to Cem Uzan entering politics and sought to ensure the shares were held by an international holding company in fear of political reprisal. This process was allegedly completed by May 2003. In June 2003, the Turkish government raided ÇEAŞ and Kepez properties, evicted personnel, seized movable and immovable properties, and served notices of cancellation of the Concession Agreements. The Claimant then requested Arbitration for the actions of the government and the cancellation of the Concession Agreements. ${ }^{308}$

The Claimant's submissions were inconsistent in regards to how they acquired shares in ÇEAŞ and Kepez. In its Request for Arbitration in February 2006, it claimed that it had performed 32 separate transactions, each having a Share Transfer Agreement ("STA"). In 2009 , it essentially cancelled the previous position, claiming those transactions were merely intents to transfer, but no transfer had occurred. The real transaction occurred by two acts of delivery ("teslim" in Turkish law) in April 2003 and May 2003. In any case, it claimed it owned $65.2 \%$ shares in ÇEAŞ and 60\% shares in Kepez. ${ }^{309}$

The Claimant claims that the Respondent had violated Article 13 of the Energy Charter Treaty by expropriating its investment. It claims the Respondent breached its obligations under Article 10(1) to treat it fairly and equitably, and also most constant protection and security. It also claimed the Turkish government took unreasonable measures. It claims that it has jurisdiction to try the case at the Energy Charter Treaty because it is a foreign national, and owns the majority shares of the Turkish company. Although Rumeli Elektrik proceeded with the case in Turkish Courts, Libananco had never done so. ${ }^{310}$

The Respondent argues firstly that the Claimant has no jurisdiction to bring forward its claims to the Energy Charter Treaty on several grounds. The main ground is that the Claimant had failed to prove it owned ÇEAŞ and Kepez shares before June 12, 2003 the date of the alleged expropriation. Therefore there was no "Investor" or "Investment", and/ or that investment was not made by a Cyprus company but rather Libananco was a shell

\footnotetext{
308ibid paras 95-96

${ }^{309}$ ibid para 130

310ibid para 102
} 
company for Turkish nationals, thus not making it a foreign national as required by the Energy Charter Treaty. It also argued that the Energy Charter Treaty cannot be relied upon because it did not enter force into Turkey until after the actions of the Respondent had taken place, instead, the Electricity Market Law is the relevant statute, and the case should be brought in Turkish national courts and it sought damages. ${ }^{311}$

Turkey also claimed that the Claimant breached its obligations under the Concession Agreements. It alleges that the Claimant breached its obligations by various claims of money laundering during certain projects, refusal to adhere and implement changes in the Electricity Market Law, violated competition laws, and failed to provide constant electricity supply to its customers which were key obligations of it under the Electricity Market Law. ${ }^{312}$

The Arbitral Tribunal had to determine whether Libananco was an "Investor" and had "Investment" as defined in Article 2 of the Energy Charter Treaty. It gathered evidence and witness statements from the Claimant including various Share Transfer Agreements. The Tribunal concluded that the inconsistency of the Claimant's evidence and witness statements indicate that the Claimant had failed prove that it owned, at the time of the alleged expropriation, shares in ÇEAŞ and Kepez. Many of the documents produced by the claimants were either forged, backdated, or nevertheless not in existence at the material time. The Respondent's evidence of the Uzan family collecting share dividends instead of Libenanco further shows that Libananco was only a front for the Uzan family. Furthermore, the Claimant could not sufficiently explain its reason for changing its position between the 2 arbitrations of how it acquired the shares. Therefore, the Claimant is not an Investor, and it could not bring a claim under the Energy Charter Treaty. Additionally, the Claimant could not benefit from Article 17(1) regarding denial of benefits. ${ }^{313}$

As well as it was a case between Energoalliance Ltd. (as Claimant) and Republic of Moldova (as Respondent). ${ }^{314}$ The Claimant, Energoalliance Ltd., was a private company

\footnotetext{
311ibid para 104

312ibid 19

${ }^{313}$ ibid paras 549-556

${ }^{314}$ Energoalians SARL v. the Republic of Moldova
} 
that produced and distributed electricity in Ukraine under a license. The Respondent is the Government of Moldova, through its state-owned enterprise "Moldtranselectro" and controlled and managed the nation's power grids under the Ministry of Industry and Energy. ${ }^{315}$ On February 1, 1999 the Claimant entered into a contract with Ukrenergo and Moldtranselectro, to purchase electricity from the former company, and export it to the latter company. Within this contract, the Claimant was to sell the electricity to Derimen Properties Ltd (the "buyer") who would then sell it for use by Moldtranselectro ("the recipient") in the form of cash or barter. These payments were usually made through exchange of power generation equipment or assignment of Derimen's claims. By January 1, 2000 Moldtranselectro's debt to Derimen amounted to USD 18,132,898.94, while Derimen owed no debt to the Claimant. However, in a separate agreement, Derimen assigned its claims against Moldtranselectro to the Claimant for the same amount above. ${ }^{316}$

Meanwhile, parallel contracts were signed between Ukrenergo, Moldtranselectro, and ZAO Stal (another Ukrainian electricity supplier). This contract provided that ZAO Stal would supply electricity to Ukenergo as compensation, while Moldtranselectro would make payments to ZAO Stal. Eventually Moldtranselectro would assign this debt in the amount of USD 4,888,900.97 in favor of Derimen, which was then assigned to the Claimant. In total, the Claimant had 2 assignments of debt from Moldtranselectro by May 30, 2000. After much negotiation and signing of Assignment Contracts, the Claimant was owed a balance of debt by Moldtranselectro of USD 9,446,433.77, with much of the rest of the debt being offset by assignments of debt by RED Nord and RED Nord Vest, which owed Moldtranselectro. 317

On October 2, 2000 the Respondent adopted Decree No. 1000 which restructured Moldtranselectro into 3 companies, the main one being "Moldelectrica". Subsequently, the Claimant filed in several courts in Moldova for the debt owed to it by RED Nord and RED Nord Vest. It eventually went to the Supreme Court, which ruled that since some of the debt was prior to January 1, 1999 that those debts were cancelled by the Law of Restructuring Eventually these debts were held to be invalid, and so the debt transferred back to

\footnotetext{
315ibid paras 67-68

316ibid paras 70-74

317ibid paras 81-86
} 
Moldtranselectro. The Claimant tried pursuing more Court claims, but due to various issues, was not able to. ${ }^{318}$

The Claimant argued that the Respondent through its actions/inactions with respect to Decree No. 1000 breached its obligation pursuant to Article 10(1) of the Energy Charter Treaty to provide "fair and equitable treatment" (FET), and failed to protect the legitimate interests and expectations of the Claimant. It believed the Decree was a discriminatory measure aimed to deprive the Claimant of the debts owed to it by the Moldtranselectro. It also claimed under Article 10(12) that the Respondent denied the Claimant of justice, by not ensuring its domestic laws provided effective means for the assertion of claims and enforcements of rights with respect to Investments and Investment agreements. The Claimant also claimed under Article 13(1) that such a deprivation is tantamount to expropriation of its assets. ${ }^{319}$

The Respondent denied all of the allegations that it breached Articles 10(1), 10(12), or 13(1) of the Energy Charter Treaty, and avers that the Claimant did not substantiate its accusations with evidence. Further, it contends that Decree No. 1000 did not deprive the Claimant a mechanism to recover its debt. It claims that the decree did not amount to an illegitimate transfer of assets, but merely a simple transfer of certain assets to new entities. Further, it claims that there was no denial of justice, as the last Court case was dismissed due to non-appearance, and the Claimant did not use all available means to lodge its claims. ${ }^{320}$

The Tribunal awarded judgment in favor of the Claimants. It ruled that Decree No. 1000 resulted in major assets of Moldtranselectro to be transferred and respective licenses were transferred to new state owned entities, with the conclusion that the Respondent's intent was to protect its assets. This implies that it did not take into consideration the legitimate interests or expectations of Moldtranselectro's creditors. The acts were not discriminatory, but still constituted a violation pursuant to Article 10(1) of the obligation to provide „sta-

\footnotetext{
318ibid paras $89-100$

${ }^{319}$ ibid paras $297-310$

${ }^{320}$ ibid paras $328-340$
} 
ble, equitable, favourable, and transparent" conditions for the Claimant's investment, and a breach of the FET standard. ${ }^{321}$

The Tribunal however, dismissed the claims that there was a denial of justice under Article 10(12), as the Claimant did not put forward any convincing argument that the General Prosecutor of Moldova abused any of Moldova's laws to prosecute it. ${ }^{322}$ Therefore, the Tribunal awarded the Claimant the sum of MDL 195,547,212 as being the cost of the Claimant's Investment in the Respondent, as well as over MDL 400,000,000 in interests, and USD 540,000 for costs. ${ }^{323}$

One more case was between Anatolie Stati, Gabriel Stati, Ascom Group S.A. Terra Raf Trans Traiding Ltd. (as Claimants) and Republic of Khazkhstan (as Respondent). ${ }^{324}$ The Claimants are Ascom Group S.A., a Moldovan company owned by Anatolie Statie and Gabriel Statie, of Moldova, as well as Terra Raf Trans Traiding, incorporated in Gibraltar and also owned by the aforementioned Claimant. The claims arose out of Kazakhstan's seizure of the claimants' petroleum operations in 2010. The claimants bought out 2 companies in 1999 that held licenses in the Borankol and Tolkyn fields in Kazakhstan. They invested in the companies over the next 10 years to turn the companies into successful exploration and production businesses. In late 2008, after the businesses had become profitable, President Nazarbyev of Kazkhstan ordered more than half a dozen government agencies including the Financial Police, Tax and Customs Agency, MEMR, National Bank of Kazkhstan, Geologicy Committee, Ecology committee, and MES to conduct audits and investigate the Claimant's companies. ${ }^{325}$ They carried out a number of inspections and audits of the companies' businesses that resulted in accusations of illegal acts directed at the claimants and their Kazakh companies, including a criminal prosecution of their general manager. Kazakhstan's actions challenged the claimants' title to their investments, subjected them to millions of dollars in tax assessments and criminal penalties and ultimately

\footnotetext{
321 ibid paras 344-347

322ibid paras 365-370

323ibid para 436

${ }^{324}$ Anatolie Stati, Gabriel Stati, Ascom Group SA and Terra Raf Trans Traiding Ltd v. Kazakhstan, SCC Case No. $\mathrm{V}(116 / 2010)$

325ibid para 296
} 
led to the seizure of their investments by Kazakh authorities in 2010. Four managers of the Claimant's companies were arrested and prosecuted for making an illegal profit of USD 980 million. ${ }^{326}$

Claimant filed claims under the Energy Charter Treaty pursuant to Article 10(1) for breach of its obligation to fair and equitable treatment, for being subjected to unreasonable or discriminatory measures, and for breaching the umbrella clause of Article 10 requiring the host State to provide constant security and protection of its investments. It also filed claims under Article 13 for direct and indirect expropriation of its investments. The Claimant's argued that Khazkhstan fabricated the grounds for criminal actions against employees of the Claimant with sham trials, ${ }^{327}$ unlawfully refused license of the Claimant's exploration contracts, and burdened the Claimant's companies with ownership and title issues that destroyed its ability to utilize its investments at market value. ${ }^{328}$ Further, it argues that indirect expropriation was conducted by the Respondent when it ordered 7 agencies to investigate the Claimant in what is dubbed as a "harassment campaign" 329 . Direct expropriation was alleged to have occurred when the Respondent's transferred significant amounts of the Claimant's assets to State Control under the Subsoil Use Contracts ${ }^{330}$. They finally claim, inter alia, that their constant security and protection rights were violated because prior to the direct and indirect expropriations, they had filed numerous complaints and submissions to the authorities investigating it, and never received a response or their complaints were dismissed. ${ }^{331}$

The respondent denied all of the claims and allegations against it. It argued that the state acted fair and equitably. It argued that the Claimant could have resolved its problems on the local level, but since it did not pursue those rights, the host State cannot be deemed to have acted unfairly. ${ }^{332}$ It admits that the investigations by the Financial Police did cause

\footnotetext{
326ibid para 463

327ibid para 898

${ }^{328}$ ibid para 911

${ }^{329}$ ibid para 271

330ibid para 1127

${ }^{331}$ ibid para 1239

332ibid para 921
} 
confusion since the Financial police is not competent to classify whether certain pipelines were "trunk" pipelines or not, but nevertheless the investigations were carried out with due process and the legal questions could be handled in Court. ${ }^{333}$ It claims that a confusion in law does not absolve the Claimant of responsibility of legal conduct. It claimed that there was no harassment campaign against the Claimant and that is factually incorrect. ${ }^{334}$ It also denied that the arrest of Mr. Cornegruta, one of the Claimant's employees, was politically motivated, and asserted that the trial was done in a lawful manner with due process. ${ }^{335}$ Lastly, it claims that the seizures of the Claimant's property were lawful and that the Claimant could have disputed them as they were involved in the inspection processes, aware of the breaches, but did not provide adequate responses to them. ${ }^{336}$

The Tribunal ruled in favor of the Claimant. It found that there was actually a campaign of harassment against the Claimant's, by looking at the timeline of events and taking together the actions of the Respondent cumulatively in context to each other, as well as the difference in treatment before and after the President ordered its decree in $2008 .{ }^{337}$ It also agreed there was expropriation by the Respondent, as the actions caused the Claimant to reduce development at Borankol and Tokyn fields during 2009-2010 and therefore lost revenue. ${ }^{338}$ The Tribunal ruled that the Respondent violated its obligations under the Energy Charter Treaty, and was ordered to pay to the Claimants $\$ 497,685,101.00$ and $50 \%$ of the Claimant's costs. ${ }^{339}$

One of the interesting case was between Yukos Universal Ltd. (as Claimant) and Russian Federation (as Respondent). ${ }^{340}$ Yukos Oil Company is a joint stock company registered in Russia dealing with oil and gas. It was one of the largest oil companies in the world at one

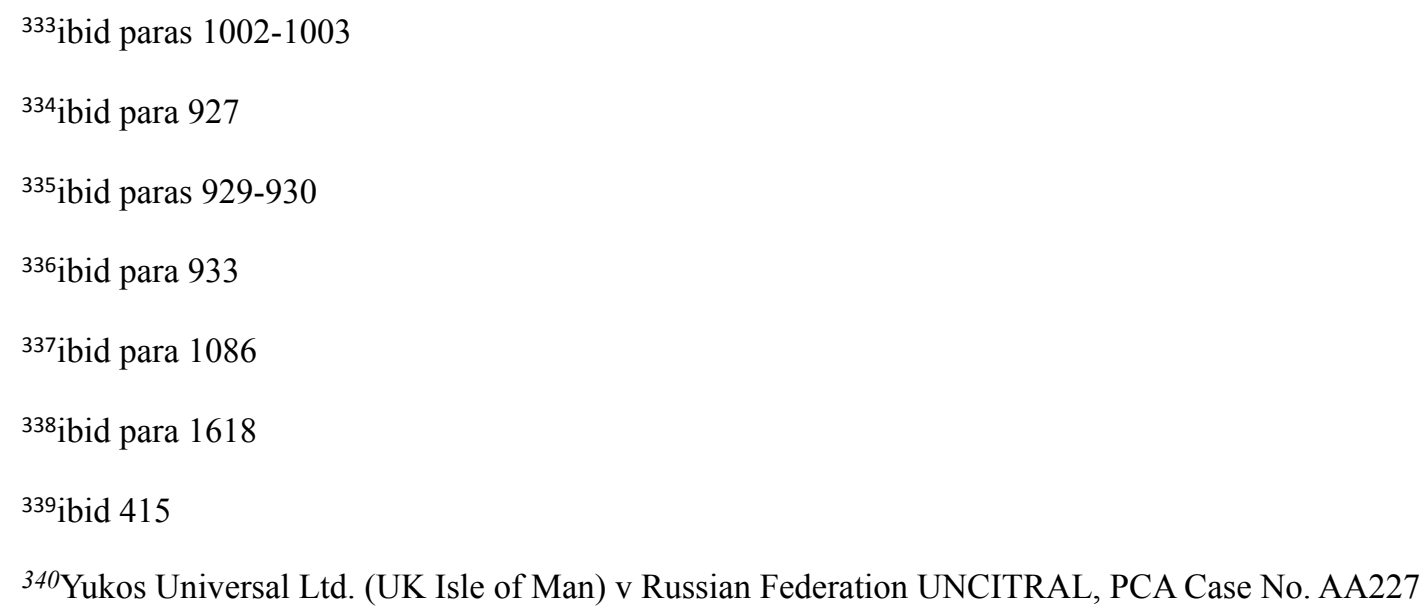


time. Approximately $70.5 \%$ of the shares of Yukos were owned by the Claimants through subsidiaries, 2 of which are registered in Cyprus, and the third on the Isle of Man The Respondent is the Russian Federation. ${ }^{341}$ In the 1990's, the Russian Federation created a tax scheme to promote economic growth in certain territorial units (known as ZATO's). The Claimant, although mainly based in Moscow, created shell companies in these ZATOs to take advantage of the lower taxation). The Russian Federation then revoked the tax scheme and re-assessed Yukos's tax liability, increasing it by a total of $\$ 18$ billion by 2004. It then filed criminal proceedings for fraud and embezzlement against the CEO of Yukos as well as other top executives and their lawyers. Top executives of Yukos were imprisoned for up to 10 years. Meanwhile, it charged the Claimant various additional VATs, froze its shares and assets, and forced the auction of the Yukos's subsidiaries to satisfy the debt. Eventually, Yukos was declared bankrupt in August 2006 and its assets were sold to Rosneft, a state owned oil company. ${ }^{342}$

The Claimant asserts that the Respondent breached its obligations under Article 10(1) and 13(1) of the Energy Charter Treaty and is entitled to full reparation. It claims that the Russian Federation subjected it to unfair and inequitable treatment, discriminatory actions, and expropriated the Claimant's investments. It claims that the Russian Federation, through massive tax claims, fabricated the debt of Yukos, thereby leaving it Bankrupt. It claims that its "tax optimization" scheme regarding low tax regions was legal and done by many vertically integrated companies in Russia. It claims that the Russian Federation's tax claims against it were unprecedented, arbitrary, and manifestly expropriatory. It contends that the Russian Court system deprived them of due process. ${ }^{343}$

The Respondent argues that the Claimant is essentially a criminal enterprise, and had used various shell companies and fronts in order to evade taxes ${ }^{344}$. It's various tax assessments between 2000-2004 were claimed to be fitting considering the substantial loss of revenue the Russian Federation was being deprived of. The actions of the Tax Ministry, even though a government organ, was acting as a commercial entity and not acting out of gov-

\footnotetext{
${ }^{341}$ ibid para 1

${ }^{342}$ ibid paras $74-80$

343ibid para 63

${ }^{344}$ ibid para 73
} 
ernmental authority. It's refusal to negotiate these fines were reasonable considering the seriousness of the criminal actions committed by the top executives of Yukos. ${ }^{345}$ Furthermore, it claims that Yukos's bankruptcy and subsequent sale of its assets to Rosneft were not acts of the Russian Federation but of those of Rosneft and the bankruptcy administrator, acting on their own behalf. ${ }^{346}$

The Arbitral Tribunal sided with the Yukos in its decision. It held that the Respondent breached its obligations under Article 13(1) of the Energy Charter Treaty by expropriating the investment of Yukos Universal Ltd. It held that the series of actions by the Russian Federation were willfully intended to bankrupt Yukos and expropriate its property. It held that the legal actions taken against Yukos in Russian court were not carried out in due process of law. It awarded the claimant USD $\$ 50,020,867,98$ in total damages, as well as USD $\$ 60$ million in costs. The Russian Federation claims the tribunal's decision was politically motivated, and will seek to set aside the award, on the basis of the illegality of Yukos's alleged tax evasion, biased investigations, arbitrary calculations of damages, baseless appraisals, among other claims. ${ }^{347}$

One more case against Russian Federation was the Claim by Hulley Enterprises Ltd. ${ }^{348}$ Hulley Enterprises Limited was a joint stock company registered in Cyprus dealing with oil and gas. It owned approximately $70.5 \%$ of the shares of OAO Yukos Oil Company ("Yukos"), along with 2 other controlling shareholders that were registered in Cyprus, and the Isle of Man, respectively. ${ }^{349}$ The Claimant joined together with the other claimant shareholders, filed this suit jointly. The Respondent is the Russian Federation. In the 1990 's, the Russian Federation created a tax scheme to promote economic growth in certain territorial units (known as ZATO's). Yukos, although mainly based in Moscow, created shell companies in these ZATOs to take advantage of the lower taxation. The Russian Federation then revoked the tax scheme and re-assessed Yukos's tax liability, increasing it by a

\footnotetext{
345ibid paras $90-97$

346 ibid paras $98-103$

347ibid paras $1575-1593$

${ }^{348}$ Hulley Enterprises Limited (Cyprus) v. The Russian Federation, UNCITRAL, PCA Case No. AA 226

349ibid para 1
} 
total of $\$ 18$ billion by 2004 . It then filed criminal proceedings for fraud and embezzlement against the CEO of Yukos as well as other top executives and their lawyers. Top executives of Yukos were imprisoned for up to 10 years. Meanwhile, it charged Yukos various additional VATs, froze its shares and assets, and forced the auction of the Yukos's subsidiaries to satisfy the debt. Eventually, Yukos was declared bankrupt in August 2006, with $60.5 \%$ of the proceeds going to the Russian Federation itself, and $39.21 \%$ as well as production assets going to Rosneft, the state owned Oil Company. ${ }^{350}$

The Claimant asserts that the Respondent breached its obligations under Article 10(1) and 13(1) of the Energy Charter Treaty and is entitled to full reparation. It claims that the Russian Federation subjected it to unfair and inequitable treatment, discriminatory actions, and expropriated the Claimant's investments. It claims that the Russian Federation, through massive tax claims, fabricated the debt of Yukos, thereby leaving it Bankrupt. It claims that its "tax optimization" scheme regarding low tax regions was legal and done by many vertically integrated companies in Russia. More importantly, it was approved by senior Russian officials. It rejects the claim by the Respondent that the VAT taxation it was forced to pay was bona fide taxation recognized under Article 21, but rather the Respondents were using taxation as a means of disguising its true intentions. It claims that the Russian Federation's tax claims against it were unprecedented, arbitrary, and manifestly expropriatory. It contends that the Russian Court system deprived them of due process. ${ }^{351}$

The Respondent argues that the Claimant is essentially a criminal enterprise, and had used various shell companies and fronts in order to evade taxes. It claims that the Tribunal's scrutiny should not be applied to its taxation measures due to the "carve-out provision" found in Article 21(1) of the Energy Charter Treaty. That provision protects the sovereignty of States with regards to fiscal matters ${ }^{352}$ and its various tax assessments between 2000-2004 were claimed to be fitting considering the substantial loss of revenue the Russian Federation was being deprived of. The actions of the Tax Ministry, even though a government organ, was acting as a commercial entity and not acting out of governmental authority. It's refusal to negotiate these fines were reasonable considering the seriousness of

\footnotetext{
350ibid para 1045

351ibid para 1379

352 ibid para 1385-7
} 
the criminal actions committed by the top executives of Yukos. Furthermore, it claims that Yukos's bankruptcy and subsequent sale of its assets to Rosneft were not acts of the Russian Federation but of those of Rosneft and the bankruptcy administrator, acting on their own behalf. 353

The Arbitral Tribunal sided with the Yukos in its decision. It held that the Respondent breached its obligations under Article 13(1) of the Energy Charter Treaty by expropriating the investment of Yukos Universal Ltd. It held that the series of actions by the Russian Federation were willfully intended to bankrupt Yukos and expropriate its property. Other companies taking advantage of the tax optimization scheme were not subjected to the same mistreatment as the Claimant. If the Claimant was only liable to pay additional VAT fines, then there would have been no need for the Russian Federation to treat employees of Yukos so harshly including jail, fines, and attacks on the legal counsel. It held that the legal actions taken against Yukos in Russian court were not carried out in due process of law as there were serious obstacles for the Claimant to overcome, including the pace of the trials, as well as the creative legal theory of the "theft" of Yukos's oil assets to imprison Yukos's CEO. Accordingly, the failure of the Respondent to accompany its expropriation with payment of prompt, adequate, and effective compensation indicates that its intention to take over Yukos. It awarded the claimant USD \$50,020,867,98 in total damages, as well as USD $\$ 60$ million in costs. The Russian Federation claims the tribunal's decision was politically motivated, and will seek to set aside the award, on the basis of the illegality of Yukos's alleged tax evasion, biased investigations, arbitrary calculations of damages, baseless appraisals, among other claims. ${ }^{354}$

One of the recent cases was between Veteran Petroleum Limited (as Claimant) and Russian Federation (as Respondent). ${ }^{355}$ Veteran Petroleum Limited was a joint stock company registered in Cyprus dealing with oil and gas. It owned approximately $11.6 \%$ of the shares of OAO Yukos Oil Company ("Yukos"), along with 2 other controlling shareholders that were

\footnotetext{
353ibid para 513

${ }^{354}$ ibid para 1585

${ }^{355}$ Veteran Petroleum Limited (Cyprus) v. The Russian Federation, UNCITRAL, PCA Case No. AA 228
} 
registered in Cyprus, and the Isle of Man, respectively. ${ }^{356}$ The Claimant joined together with the other claimant shareholders, filed this suit jointly. The Respondent is the Russian Federation. In the 1990's, the Russian Federation created a tax scheme to promote economic growth in certain territorial units (known as ZATO's). Yukos, although mainly based in Moscow, created shell companies in these ZATOs to take advantage of the lower taxation. The Russian Federation then revoked the tax scheme and re-assessed Yukos's tax liability, increasing it by a total of $\$ 18$ billion by 2004 . It then filed criminal proceedings for fraud and embezzlement against the CEO of Yukos as well as other top executives and their lawyers. Top executives of Yukos were imprisoned for up to 10 years. Meanwhile, it charged Yukos various additional VATs, froze its shares and assets, and forced the auction of the Yukos's subsidiaries to satisfy the debt. Eventually, Yukos was declared bankrupt in August 2006, with $60.5 \%$ of the proceeds going to the Russian Federation itself, and $39.21 \%$ as well as production assets going to Rosneft, the state owned Oil Company. ${ }^{357}$ The Claimant asserts that the Respondent breached its obligations under Article 10(1) and 13(1) of the Energy Charter Treaty and is entitled to full reparation. It claims that the Russian Federation subjected it to unfair and inequitable treatment, discriminatory actions, and expropriated the Claimant's investments. It claims that the Russian Federation, through massive tax claims, fabricated the debt of Yukos, thereby leaving it Bankrupt. It claims that its "tax optimization" scheme regarding low tax regions was legal and done by many vertically integrated companies in Russia. More importantly, it was approved by senior Russian officials. It rejects the claim by the Respondent that the VAT taxation it was forced to pay was bona fide taxation recognized under Article 21, but rather the Respondents were using taxation as a means of disguising its true intentions. It claims that the Russian Federation's tax claims against it were unprecedented, arbitrary, and manifestly expropriatory. It contends that the Russian Court system deprived them of due process. ${ }^{358}$

The Respondent argues that the Claimant is essentially a criminal enterprise, and had used various shell companies and fronts in order to evade taxes. It claims that the Tribunal's scrutiny should not be applied to its taxation measures due to the "carve-out provision"

\footnotetext{
356ibid para 1

357ibid para 1045

358ibid para 1379
} 
found in Article 21(1) of the Energy Charter Treaty. That provision protects the sovereignty of States with regards to fiscal matters ${ }^{359}$ and its various tax assessments between 2000-2004 were claimed to be fitting considering the substantial loss of revenue the Russian Federation was being deprived of. The actions of the Tax Ministry, even though a government organ, was acting as a commercial entity and not acting out of governmental authority. It's refusal to negotiate these fines were reasonable considering the seriousness of the criminal actions committed by the top executives of Yukos. Furthermore, it claims that Yukos's bankruptcy and subsequent sale of its assets to Rosneft were not acts of the Russian Federation but of those of Rosneft and the bankruptcy administrator, acting on their own behalf. ${ }^{360}$

The Arbitral Tribunal sided with the Claimants in its decision. It held that the Respondent breached its obligations under Article 13(1) of the Energy Charter Treaty by expropriating the investment of Yukos Universal Ltd. It held that the series of actions by the Russian Federation were willfully intended to bankrupt Yukos and expropriate its property. Other companies taking advantage of the tax optimization scheme were not subjected to the same mistreatment as the Claimant. If the Claimant was only liable to pay additional VAT fines, then there would have been no need for the Russian Federation to treat employees of Yukos so harshly including jail, fines, and attacks on the legal counsel. It held that the legal actions taken against Yukos in Russian court were not carried out in due process of law as there were serious obstacles for the Claimant to overcome, including the pace of the trials, as well as the creative legal theory of the "theft" of Yukos's oil assets to imprison Yukos's CEO. Accordingly, the failure of the Respondent to accompany its expropriation with payment of prompt, adequate, and effective compensation indicates that its intention to take over Yukos. It awarded the claimant USD \$50,020,867,98 in total damages, as well as USD \$60 million in costs. The Russian Federation claims the tribunal's decision was politically motivated, and will seek to set aside the award, on the basis of the illegality of Yukos's alleged tax evasion, biased investigations, arbitrary calculations of damages, baseless appraisals, among other claims. ${ }^{361}$

\footnotetext{
359 ibid para $1385-7$

${ }^{360}$ ibid para 513

361ibid para 1585
} 
Also there was a case between State Enterprise 'Energorynok' (as Claimant) and Republic of Moldova (as Respondent). ${ }^{362}$ The Claimant was a state enterprise of Ukraine named Energorynok. The Respondent was the Republic of Moldova. ${ }^{363}$ On March 20, 1993 the Governments of Ukraine and Moldova signed an agreement on Cooperation in the Field of Electricity. On February 20, 1995 the Ministry of Energy in Ukraine and Moldova entered into an Agreement on the Parallel Operation of the Energy Systems of Ukraine and Moldova ("the APO"). This essentially was an agreement relating to the transportation, distribution, and supply of Energy Materials and Products through distribution grids. In the APO, Article (4)3 states that surplus energy shall be compensated at a three-area tariff rate. Pursuant to this agreement, in 1998, the National Energy Company "Ukrenergo" of Ukraine was formed under Order No. 54 of the Ukrainian Ministry of Fuel for the purposes of this agreement. $^{364}$

In October 1998, an overflow of electricity amounting to 50,000,000 kWh occurred from Ukraine to Moldova, triggering article 4.3. The amount of electricity nor compensation due is not in dispute, but rather, whether compensation has already been made, and from and to whom the compensation is owed..$^{365}$

On 25 November 1998, a Surety agreement was entered between Ukrenergo and the International Fund for Emergency Assistance for the Black Sea Economic Cooperation States ("the Fund"). It guaranteed to the Claimant Moldtranselectro (Respondent) to repay the existing debt from the $50,000,000 \mathrm{kWh}$ of electricity. It planned to compensate the debt through the supply of equipment equal to the value of the debt. In $1999,80 \%$ of the obligation under the Surety agreement was repaid through equipment. However, the Arbitration Court of Kiev declared in December 1999 that the Surety agreement was null and void on the grounds that the Ukrainian Ministry had not authorized the Claimant to sign the agreement. Following this nullification, the equipment was returned. The Respondent contends, however, that although the equipment was returned, the equipment was supplied to

\footnotetext{
${ }^{362}$ State Enterprise "Energorynok" (Ukraine) v. The Republic of Moldova, SCC Arbitration V 2012/175

363ibid paras 1-2

${ }^{364}$ ibid paras $14-24$

365ibid para 22
} 
Ukraine pursuant to other contracts than the Surety agreements, and thus the compensation for the overflow was paid..$^{366}$

Furthermore, the Claimant brought an action in 2002 in the Economic Court in Kiev against the Moldovan Ministry ("Energorynok v. The Ministry of Energy Industry of the Republic of Moldova and InTA-Audit"). The Court in this case awarded the Claimants the amount of USD 1,745,412.71. The Claimants therefore wished to enforce that decision in the present Tribunal. ${ }^{367}$

The Claimant wishes to claim the award arising out of the 2002 Court decision that effectively declares its financial assets as an 'investment' in the energy sector pursuant to the Energy Charter Treaty. It also claims the Tribunal does have jurisdiction to hear the dispute under the Energy Charter Treaty. It claims that Moldova is in violation of international law as the Courts delayed and extended to enforce the 2002 decision for 7 years. It lastly claims that Moldova violated its obligations under Article 13(1) for de facto expropriating its investment, as well as breaching Article 10.1 of the fair and equitable treatment provision. ${ }^{368}$

The Respondent's position is that the Tribunal does not have jurisdiction to hear the case. It also rejects that it had violated any obligations under Energy Charter Treaty. It rejects that it had violated Moldovan or international law in regards to the 2002 Decision. It considers the 2002 decision violates international and national law and therefore unlawful and unenforceable. ${ }^{369}$

The Tribunal found that it lacked jurisdiction to hear the case. It considered the APO was evidence of an investment between two Ministries, and that two state entities NCC and Moldenergo were assigned in Article 10 of that agreement to carry out the performance of the technical and operational functions. An investor is not precluded from being an investor as stated in Article 1(7) of the Energy Charter Treaty, but in this case, the Claimants were not the investors themselves, as the Claimant has had no role in the economic activity

\footnotetext{
${ }^{366}$ ibid paras 22-25

367ibid para 26

${ }^{368}$ ibid para 54

${ }^{369}$ ibid para 55
} 
carried out under the APO. ${ }^{370}$ Article 1(6) requires that an Investor must control or own the asset in the host State, which the Claimants did not have any financial equity in. The Claimant asserted that the debt owed to it can be considered an investment, and that payment for the consumed electricity was the return from its investment. It also claimed that the debt owed to it was an "ownership right" rather than a contractual right. The Arbitral Tribunal found these submissions to be inconsistent, as the Claimant is trying to be both a party to the APO but a $3^{\text {rd }}$ party to the APO at the same time. The Claimant does have a financial interest in recovering the Debt it acquired, but not in the APO. The proof is that it has no ability to influence the management and operation of the transmission of electricity under the APO and never had, nor chose the board of directors or any managing body. ${ }^{371}$

Later case between Mamadoil Jetoil Greek Petroleum Products Societe S.A (as Claimant) and Republic of Albania (as Respondent) ${ }^{372}$ came up in which the Claimant was Mamidoil Jetoil Greek Petroleum Products Societe S.A. ("Mamidoil”), a Greek company which mainly specialized in the acquisition, storage, distribution and sales of fuel and oil related products. It also had owned its subsidiary, Mamidoil Albanian, to be the local company in Albania. The Respondent is the Republic of Albania. ${ }^{373}$

Since the early 90's, the Claimant had been involved in different commercial activities related to transport, storage, and trade of petroleum related products. By 1995, the Claimant made several investment proposals to build a tank farm in the port of Durres. The port of Duress was chosen because at the time, the Albanian government was promoting investment in that area. It submitted its proposals to the Albanian Minister of Economy and Privatization. By January 6, 1999 the Directorate of Maritime Port of the Ministry of Works and Transport approved the tank farm to be constructed for 6 million USD for 14 thousand sq. miles, and this was approved by the Respondent and the Duress port authority by September 1, 1999. ${ }^{374}$

\footnotetext{
${ }^{370}$ ibid para 81

371 ibid paras 90-92

${ }^{372}$ Mamidoil Jetoil Greek Petroleum Products Societe S.A. v. Republic of Albania, ICSID Case No. ARB/11/24

373ibid para 1

${ }^{374} \mathrm{ibid}$ paras $65-83$
} 
At the same time, the Respondent had requested assistance from the World Bank in conducted a feasibility study as to how to privatize various industrial sectors. The conclusion was reached and endorsed by the European Commission that the Port of Duress was in deplorable condition and facilities should be transferred to a new location by $2009-2010^{375}$. Within this time, the Claimant had imported, transported, and marketed oil products in Albania. But after June 2009, the port had closed and the Claimant could only a do a fraction of the business it was doing before. This was also due to other factors issued by the Respondent's directives, including new requirements for security reserves of fuel, fixing of a progressive standard of diesel quality, and taxing policies, although these directives were voided on July 24, 2009. The Claimant tried to apply for compensation to relocate its tank farm to another location, but that request was denied due to the Claimant being "fully aware that such processing activity in the port of Duress would have been temporary". ${ }^{376}$ The Claimant brought claims under Article 13(1) of the Energy Charter Treaty for expropriation of investment without compensation, as well as breach of the fair and equitable standard (FET) under Article 10(1), as well as refraining from unreasonable and discriminatory measures, and constant protection and security also in Article 10(1). ${ }^{377}$ The Claimants argued that it had only invested in Albania, specifically the port of Durres, only after presenting a 20 year business plan to the Respondents, including meetings with the Prime Minister and other government officials. It claims the Respondents recommended Durres as an investment site, and the Respondents never mentioned that it planned to change the use of the port in the near future. ${ }^{378}$ It also argued that the Respondent gave it full authorization in July 2000 to complete construction work by December. It also argued that the Respondent did not change the use of the port due to public policy considerations, but rather due to its deal with Petrolifera, a Canadian owned oil company. Furthermore, the European Commission approved review of the area included that it might have to compensate companies affected by the change of port due to early termination of leases. ${ }^{379}$

\footnotetext{
${ }^{375}$ ibid para 94

376 ibid paras 109-137

377ibid para 496

378ibid paras $145-146$

379ibid paras $155-160$
} 
The Respondent denies all the claims and disputes the arguments that it had expropriated the Claimant's property. It argued that the investments in the tank farm were illegal due to lacking necessary permits. ${ }^{380}$ Furthermore, the Claimant allegedly had full knowledge of the imminent re-zoning plans. ${ }^{381}$ Furthermore, it could have applied for new trading permits like other companies in the area had. If the Claimants had not pursued them, it is due to their negligence or bad business judgment, not the fault of the Respondent. ${ }^{382}$ It further argued that it is not liable to pay compensation for an Investor's investment if the country adopts non-discriminatory measures for bona fide regulations aimed at the general welfare. $^{383}$

The Tribunal had to carefully examine the disputed facts and consider the evidence of documentation and witness testimony. It found that the Respondent did not expropriate the Claimant's investment, although the regulations had reduced the profitability of the investment but do not shut it down completely, citing El Paso v. Argentina. ${ }^{384}$ It also did not find the Respondent liable for breaching the FET standard, as the Respondent had was under no contractual obligation to keep the port open for the Claimant's vessels. ${ }^{385}$ It also rejected the argument that the changes in law from the European Commission's review did not violate its obligation to create a stable legal framework. ${ }^{386}$ The Tribunal rejected all the claims. $^{387}$

The most recent case was between Electrabel S.A (as Claimant) and Republic of Hungary (as Respondent). ${ }^{388}$ The Claimant, Electrabel, was an energy generation company based in Belgium. The Respondent was the Republic of Hungary. The main issue between the par-

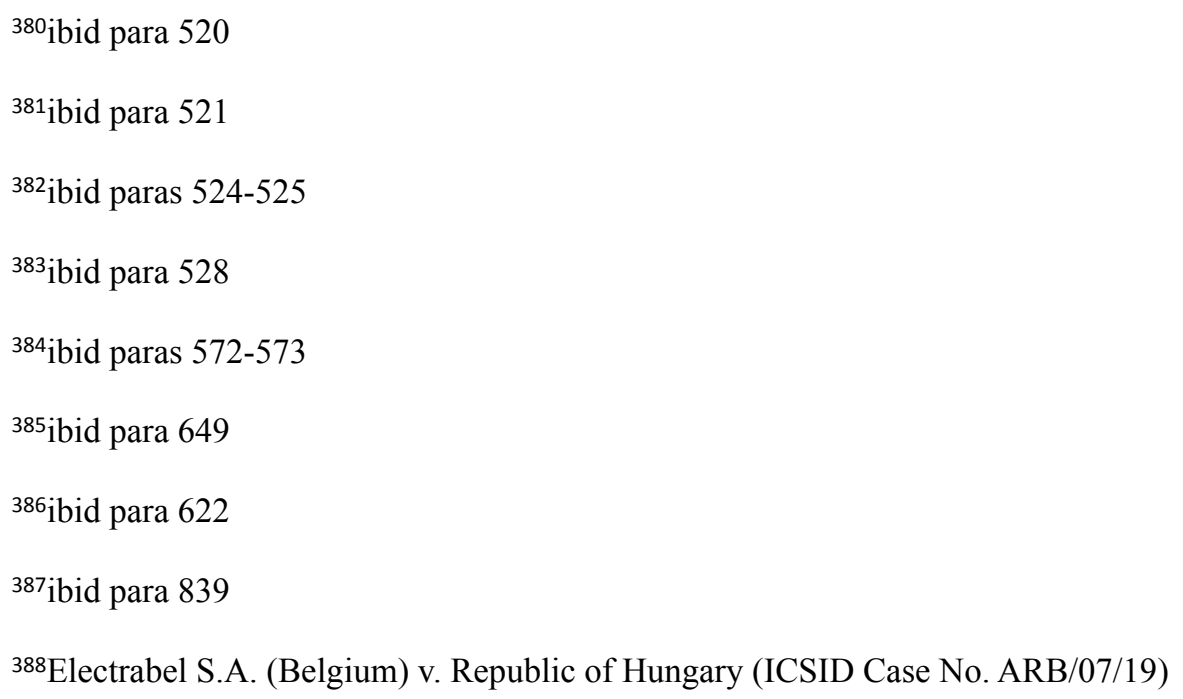


ties stemmed from the termination of a Power Purchase Agreement ("PPA") between Electrabel's subsidiary in Hungary named Dunamenti Eromu Rt ("Dunamenti”) and a Hungarian electricity supply company. During the life of the PPA, Hungary had provided State aid to the company amounting to 125 billion HUF. The termination of the PPA, however, effectively left the Claimant's Hungarian subsidy "stranded" with no one to sell the electricity to. The European Commission estimated that the total "stranded costs" of Dunamenti was 147 billion HUF, but that Dunamenti still had to repay 125 billion HUF to the Republic of Hungary (leaving a difference of 22 billion HUF or "net stranded costs"). Hungary had the option to either 1) not compensate the Claimant and claim the 125 billion HUF, 2) forgive the 125 billion HUF and reimburse the Claimant for 22 billion HUF, or 3) forgive the 125 billion and not reimburse the Claimant. They chose the $3^{\text {rd }}$ option. ${ }^{389}$ The claimant then requested Arbitration proceedings.

The parties then chose to have bifurcated proceedings. On 30 November 2012, the Tribunal issued its decision on "Jurisdiction, Applicable Law and Liability". It concluded that under Article 25 and 41 of the ICSID Convention, that it had jurisdiction to hear the dispute. As far as claims, it saved the claim that Hungary had breached its obligations of providing fair and equitable treatment (FET) to the Claimant under Article 10(1) of the Energy Charter Treaty for the $2^{\text {nd }}$ proceedings. It also dismissed several other claims in regards to compensation, liability, and costs, leaving only the main claim. ${ }^{390}$

The Claimant's main claim was that it had "legitimate expectations" under the Energy Charter Treaty to be provided fair and equitable treatment at the time of its investments in Dunamenti. This FET was breached by the termination of the PPA agreement. The Claimant argued that the Respondent made specific representations that it would carry out the PPA agreement for the duration stated in the PPA, which is tantamount to a contractual guarantee in regards to a reasonable profit and reasonable return on its investment. ${ }^{391}$

It also claimed that Hungary acted arbitrarily, firstly by not fully compensating Dunamen$\mathrm{ti}^{392}$, secondly, by not balancing the actual interests of the Claimant in calculating the

\footnotetext{
${ }^{389}$ ibid paras $1-5$

390ibid para 51

391ibid para 155

392ibid para 170
} 
"stranded costs" of Dunamenti, ${ }^{393}$ by not providing compensation for the "net stranded costs" as other nations such as Poland and Portugal had in similar situations, ${ }^{394}$ by the Respondent's representation that it would pay the "net stranded costs" but then changing its mind, ${ }^{395}$ and by providing some compensation to one of its shareholders (MVM) but not the Claimant. ${ }^{396}$

The Respondent rejected all these claims, claiming it did not breach the FET standard, that it had rejected the PPA due to public interests in doing so, that it acted reasonably and equitably, and that it had compensated the Claimant adequately by setting off the State Aid reimbursement that Dunamenti owed to it. It asserted that it had made numerous attempts through the European Commission to adduce Dunamenti's stranded costs. ${ }^{397}$ It did not deny that budgetary concerns were a reason for not compensating the Claimant, but that it was a legitimate regulatory interest. 398

The Tribunal rejected all the claims of the Claimant. On the argument of legitimate expectations, it considered that specific representations are not always indispensable to a claim, if it merely makes a difference in the investor's knowledge, and the reasonableness and legitimacy of its expectations. The Claimant failed to establish what its reasonable expectations were. ${ }^{399}$

The Tribunal also concluded that the PPA was vulnerable to a change in applicable law as it had no stabilization clause, nor any clause containing any guarantee of profit or return. 400 It also concluded that the FET standard allows for a State to balance its interests with that of the investor. Generally speaking, Host countries are given wider discretion to regulate

\footnotetext{
${ }^{393}$ ibid paras $171-172$

${ }^{394}$ ibid para 173

395ibid para 174

396ibid para 175

397ibid para 172

398ibid para 170

${ }^{399}$ ibid para 155

${ }^{400}$ ibid para 158
} 
law within its own borders. ${ }^{401}$ Therefore, its choosing to set off the State aid it was owed while not paying the "net stranded" costs were reasonable and legitimate. 402

As far as arbitrariness, the Tribunal held that the Claimant did not prove that the Respondent acted disproportionately, inequitably, irrationally, or unreasonably with the Claimant. ${ }^{403}$ It held that the compensations to MVM for the costs of market liberalisation did not lead to the argument that it acted arbitrarily because MVM was not in a materially similar position as the Claimant. ${ }^{404}$ Lastly, it held that the Respondent's choice to compensate 125 billion HUF by setting off the same amount it was supposed to receive from the Claimant for State Aid was reasonable and proportionate. The Tribunal dismissed all the claims of the Claimant.

The last published case was between Hrvatska Elektroprivreda, D.D. (as Claimant) and Republic of Slovenia (as Respondent). 405 The Claimant ("HEP”) was the national electric company of Croatia since 1994, and completely owned by the Government of Croatia. The Respondent was the Republic of Slovenia. The relevant party involved in the dispute was Elektro-Slovenija, d.o.o. Ljubljana (“ELES-GEN") which was a subsidiary of ElektroSlovenija, d.o.o. ("ELES"), the national electric company of Slovenia. Together they formed a joint venture company named Nuklearna Elektrana Krško ("NEK"), each contributing $50 \%$ of the funds. They built the Krško NPP power plant. Since they were equal partners, they followed the "parity" principle, and were to be equal in all aspects of the plant. Their partnership was regulated by 4 governing agreements signed between 1970 and 1984. By 1991, they were separate countries. ${ }^{406}$

During the years after independence, the Slovenian Government took some measures that the HEP claimed were breaking the parity principle and basic provisions of the Governing Agreements. The Respondents disconnected the Claimant's electricity lines and ended

\footnotetext{
${ }^{401}$ ibid para 165

402ibid para 166

${ }^{403}$ ibid para $167-168$

404ibid para 175

${ }^{405} \mathrm{Hrvatska}$ Elektroprivreda d.d. v. Republic of Slovenia, ICSID Case No. ARB/05/24

406ibid paras 7-10
} 
electricity delivers to the Claimant on 30 July 1998. The Respondent also issued a "Governmental Decree" which the Claimant views as affected his rights equal partner. ${ }^{407}$

In June 2001, the two countries entered negotiations "the 2001 Agreement" on restoring rights and deliveries back to the Claimant. They proposed to "wipe the slate clean" and no claims to electricity would be entertained up to 30 June 2002. The Claimant claims that the Respondent failed to neither restore its rights nor resume electricity deliveries until 19 April 2003, nearly 10 months late. It seeks compensation for the 10 months of failed electricity deliveries plus restoring its role as equal partners. ${ }^{408}$

The Claimant argued that by not restoring electricity deliveries until 30 June 2002, the Respondent had violated Articles 10(1) and 13 of the Energy Charter Treaty ("Energy Charter Treaty”). It only claimed for the period of 30 June 2003, to 19 April 2003, as any previous claims were to be dropped by virtue of the 2001 Agreement. The claimant was also claiming a breach of contract based on the 2001 Agreement. Earlier Tribunal judgments dismissed the Energy Charter Treaty claims, and the Claimant sought to restore or reverse the decision to drop of that issue. It argued that its Claims were made based on 2 legal bases, that being the 2001 Treaty between Croatia and Slovenia, and also the Energy Charter Treaty. 409

The Respondent's argument is that 2 negotiations between the parties in June and November 2002 were considered to be acquiescence to liability for those claims, and that otherwise, the liability had been satisfied by the offers of electrical power made to the HEP during those negotiations. Further, it stated that the claims of the Energy Charter Treaty were dropped vis-à-vis the 2001 Agreement, citing Wena Hotels Ltd v Arab Republic of Egypt. It considered the Tribunal decision to be factually and legally correct. It asserted that the 2001 Agreement was a single compensation package and waived any other claims. $^{410}$

The 2 parties went through several levels of arbitration before reaching the ICSID, and this case brief reflects the final award. The results of that arbitration were a financial settlement

\footnotetext{
${ }^{407}$ ibid paras $11-14$

408 ibid paras $14-15$

${ }^{409}$ ibid paras $562-565$

${ }^{410}$ ibid paras $566-570$
} 
as of June 30, 2002 and waiving off all previous claims. It was however subject to the determination of several issues, whether liability was acquiesced to by the Claimant during those 2 negotiations, and whether the liability was satisfied by 2 offers of electrical power made to the Claimant. This case brief will focus on the issue with regards to the dismissal of the Energy Charter Treaty by the previous Tribunal. The Arbitral Tribunal finally held that the Energy Charter Treaty claims made against the Respondent were only alternative treaty bases of claim. These Energy Charter Treaty claims automatically fell out of consideration once the 2001 Agreement came up with a single compensation package to satisfy the entire claim. ${ }^{411}$

${ }^{411}$ ibid paras $573-580$ 


\section{Investment protection and related issues in the Energy Charter Treaty}

\subsection{The extent of protecting energy investments in the Energy Charter Treaty}

\subsubsection{Before the Energy Charter Treaty}

International lenders, as well as investors, face an expropriation risk for the investments of their projects. Projects under foreign authority, particularly in those countries that are not stable politically or lie in the rank of developing countries, face extra risks due to the lack of insurances in the legal/political structure, so the treaty and contractual protections are required in order to provide the safeguard to such type of investments. The main reason behind such types of insurance is that the protection for the projects of foreign lenders and investors is not sufficiently established, and such a risk becomes the reason for the imposition of these restrictions on those particular countries. So, in order to cope with this difficulty and give assurance to the lenders and investors, the number of contractual protections is increasing, so that the market standard for projects of international level may increase.

The participants of international trade were eager to improve energy security in order to supply it, to maximize the production efficiency, transport, conversion, distribution, as well as use energy in order to improve security and to minimize the problems related to the environment, on an economic basis that is acceptable. In the framework of state sovereignty, regarding the right of sovereignty over energy resources, and in the spirit of economic and political cooperation, they decided to further the development and promotion of an energy market that is efficient in the entirety of Europe, as well as a better functioning global market that is based on the non-discrimination principle and on the formation of the marketoriented prices that account for environmental concerns. They made efforts to create an environment that is in favor of all. Its basic objective is to provide a flexible environment for trade at an international level.

The chief purposes of this signing are the principles and objectives implemented in the charter, and to broaden the cooperation on an urgent basis, with negotiating in goodwill, which is considered the fundamental basis of the protocols and the agreement. The major 
areas of cooperation may include organizational and horizontal issues, energy efficiency, transportation, prospecting, oil production and production, use and production of natural gas as well as its transmission, all the features of nuclear fuel, and power station modernization. All the features of the coal cycle, the development of new energy sources that are renewable, technology transfer and encouragement to develop energy sources and the cooperation necessary for tackling major accidents. They, in particular, check particular circumstances that face the USSR and Central and Eastern Europe. With the help of a party requesting transitional status, the particular arrangements are made as a part of the compliance.

The General Agreement on Tariffs and Trade (GATT), as well as the World Trade Organization of 1994, is playing their roles in promoting free international trade. GATT has legal and political origins founded on the principles of the World Trade Organization (WTO), and provides some important provisions in this regard. It also deals with the large number of problems related to free international trade and resolves many disputes. It also provides motivation for countries to adopt the system of free trade. GATT also identifies the need to protect the environment.

Most recently, GATT was negotiated with the WTO members in the Uruguay Round of 1986-1994 as the previous round discussion. The GATT was conceived for market openings as well as to reduce the barriers to trade. The GATT also provides to countries a legal ground for pursuing international trade. The basic purpose and aim of the GATT were to omit protectionism, as harmful to free trade. This protectionism became the reason for the fall in trade volumes to $65 \%$ during the time of the Great Depression. Through the usage tariff removal as a tool, GATT boosted trade at international levels and became the reason for the restoration of the health of the world economy after the World War II devastation. GATT is considered the first step in promoting easy conditions as well as a flexible environment at the international level.

\subsubsection{Relevant articles of the Energy Charter Treaty}

The articles of the Energy Charter Treaty provide promotion, treatment as well as protection of energy-related investments. The question is whether these articles create sufficient 
amount of stability and protection for foreign investments. To find the answer, first we have to look at the following articles of the Energy Charter Treaty.

\subsubsection{Article 3: International market}

Article 3 of the Energy Charter Treaty deals with the international market in general, and states:

The Contracting Parties shall work to promote access to international markets on commercial terms, and generally to develop an open and competitive market, for Energy Materials and Products.

According to the article, the contracting parties will make efforts, within their means, to increase international trade for the sake of getting more access to international markets. Its other purpose is to generally develop a market that is competitive and open, in relation to the materials and products of energy and other equipment that is related to energy.

The article aims to increase the volume of international trade and provides easy access to other countries for making beneficial investments in the country of their interest. Thus, this article is considered important due to its ability to widen the international market as well as competition. ${ }^{412}$

\subsubsection{Article 7: Transit}

To understand the article's importance, let's take a look at it:

(1) Each Contracting Party shall take the necessary measures to facilitate the Transit of Energy Materials and Products consistent with the principle of freedom of transit and without distinction as to the origin, destination or ownership of such Energy Materials and Products or discrimination as to pricing on the basis of

\footnotetext{
412Pavel Tomanek, 'Italy And Spain Hit By More Solar Energy Cases | Global Investment Protection' <http:// www.globalinvestmentprotection.com/2015/09/10/italy-and-spain-hit-by-more-solar-energy-cases/> accessed 20 October 2017
} 
such distinctions, and without imposing any unreasonable delays, restrictions or charges.

(2) Contracting Parties shall encourage relevant entities to co-operate in:

(a) modernising Energy Transport Facilities necessary to the Transit of Energy Materials and Products;

(b) the development and operation of Energy Transport Facilities serving the Areas of more than one Contracting Party;

(c) measures to mitigate the effects of interruptions in the supply of Energy Materials and Products;

(d) facilitating the interconnection of Energy Transport Facilities.

(3) Each Contracting Party undertakes that its provisions relating to transport of Energy Materials and Products and the use of Energy Transport Facilities shall treat Energy Materials and Products in Transit in no less favourable a manner than its provisions treat such materials and products originating in or destined for its own Area, unless an existing international agreement provides otherwise.

(4) In the event that Transit of Energy Materials and Products cannot be achieved on commercial terms by means of Energy Transport Facilities the Contracting Parties shall not place obstacles in the way of new capacity being established, except as may be otherwise provided in applicable legislation which is consistent with paragraph (1).

(5) A Contracting Party through whose Area Energy Materials and Products may transit shall not be obliged to

(a) permit the construction or modification of Energy Transport Facilities; or

(b) permit new or additional Transit through existing Energy Transport Facilities, which it demonstrates to the other Contracting Parties concerned would endanger the security or efficiency of its energy systems, including the security of supply.

Contracting Parties shall, subject to paragraphs (6) and (7), secure established flows of Energy Materials and Products to, from or between the Areas of other Contracting Parties.

(6) A Contracting Party through whose Area Energy Materials and Products transit shall not, in the event of a dispute over any matter arising from that Transit, inter- 
rupt or reduce, permit any entity subject to its control to interrupt or reduce, or require any entity subject to its jurisdiction to interrupt or reduce the existing flow of Energy Materials and Products prior to the conclusion of the dispute resolution procedures set out in paragraph (7), except where this is specifically provided for in a contract or other agreement governing such Transit or permitted in accordance with the conciliator's decision.

(7) The following provisions shall apply to a dispute described in paragraph (6), but only following the exhaustion of all relevant contractual or other dispute resolution remedies previously agreed between the Contracting Parties party to the dispute or between any entity referred to in paragraph (6) and an entity of another Contracting Party to the dispute:

(a) A Contracting Party to the dispute may refer it to the Secretary-General by a notification summarizing the matters in dispute. The Secretary-General shall notify all Contracting Parties of any such referral.

(b) Within 30 days of receipt of such a notification, the Secretary-General, in consultation with the parties to the dispute and the other Contracting Parties concerned, shall appoint a conciliator. Such a conciliator shall have experience in the matters subject to dispute and shall not be a national or citizen of or permanently resident in a party to the dispute or one of the other Contracting Parties concerned.

(c) The conciliator shall seek the agreement of the parties to the dispute to a resolution thereof or upon a procedure to achieve such resolution. If within 90 days of his appointment he has failed to secure such agreement, he shall recommend a resolution to the dispute or a procedure to achieve such resolution and shall decide the interim tariffs and other terms and conditions to be observed for Transit from a date which he shall specify until the dispute is resolved.

(d) The Contracting Parties undertake to observe and ensure that the entities under their control or jurisdiction observe any interim decision under subparagraph (c) on tariffs, terms and conditions for 12 months following the conciliator's decision or until resolution of the dispute, whichever is earlier.

(e) Notwithstanding subparagraph (b) the Secretary-General may elect not to appoint a conciliator if in his judgement the dispute concerns Transit that is or has been the sub- 
ject of the dispute resolution procedures set out in subparagraphs (a) to (d) and those proceedings have not resulted in a resolution of the dispute.

(f) The Charter Conference shall adopt standard provisions concerning the conduct of conciliation and the compensation of conciliators.

(8) Nothing in this Article shall derogate from a Contracting Party's rights and obligations under international law including customary international law, existing bilateral or multilateral agreements, including rules concerning submarine cables and pipelines.

(9) This Article shall not be so interpreted as to oblige any Contracting Party which does not have a certain type of Energy Transport Facilities used for Transit to take any measure under this Article with respect to that type of Energy Transport Facilities. Such a Contracting Party is, however, obliged to comply with paragraph (4).

(10)For the purposes of this Article:

(a) "Transit" means

(i) the carriage through the Area of a Contracting Party, or to or from port facilities in its Area for loading or unloading, of Energy Materials and Products originating in the Area of another state and destined for the Area of a third state, so long as either the other state or the third state is a Contracting Party; or

(ii) the carriage through the Area of a Contracting Party of Energy Materials and Products originating in the Area of another Contracting Party and destined for the Area of that other Contracting Party, unless the two Contracting Parties concerned decide otherwise and record their decision by a joint entry in Annex N. The two Contracting Parties may delete their listing in Annex $\mathrm{N}$ by delivering a joint written notification of their intentions to the Secretariat, which shall transmit that notification to all other Contracting Parties. The deletion shall take effect four weeks after such former notification.

(b) "Energy Transport Facilities" consist of high-pressure gas transmission pipelines, high-voltage electricity transmission grids and lines, crude oil transmission pipelines, coal slurry pipelines, oil product pipelines, and other fixed facilities specifically for handling Energy Materials and Products. 
From the perspective of energy-related foreign investments, this article helps to ensure an equal playing field and competition when it comes to the transit of energy materials and products. This is another manifestation of the utility of the Energy Charter Treaty to foreign investors.

\subsubsection{Article 10: Promotion, protection, and treatment of investments}

This is where the real 'meat' of the Energy Charter Treaty starts, at least from the perspective of investment protection. Let's look at its first paragraph:

(1) Each Contracting Party shall, in accordance with the provisions of this Treaty, encourage and create stable, equitable, favourable and transparent conditions for Investors of other Contracting Parties to make Investments in its Area. Such conditions shall include a commitment to accord at all times to Investments of Investors of other Contracting Parties fair and equitable treatment. Such Investments shall also enjoy the most constant protection and security and no Contracting Party shall in any way impair by unreasonable or discriminatory measures their management, maintenance, use, enjoyment or disposal. In no case shall such Investments be accorded treatment less favourable than that required by international law, including treaty obligations. Each Contracting Party shall observe any obligations it has entered into with an Investor or an Investment of an Investor of any other Contracting Party.

This is the first clear statement in the Energy Charter Treaty that explicitly spells out the contracting parties' intention of protecting each other's investments, and banning the use of discriminatory or otherwise unreasonable measures that would impair or hinder foreign investors.

Moving onto Article 10 (2) and (3): 
(2) Each Contracting Party shall endeavor to accord to Investors of other Contracting Parties, as regards the Making of Investments in its Area, the Treatment described in paragraph (3).

(3) For the purposes of this Article, "Treatment" means treatment accorded by a Contracting Party which is no less favourable than that which it accords to its own Investors or to Investors of any other Contracting Party or any third state, whichever is the most favourable.

Here, the Energy Charter Treaty establishes the Most Favoured Nation (MFN) standard of treatment for investors belonging to the contracting parties, in relation to the areas covered by the Energy Charter Treaty. Furthermore, Article 10 (4) mandated the creation of a supplementary treaty, which obliged its signatories to expand the scope of the Energy Charter Treaty MFN treatment to select other parties:

(4) A supplementary treaty shall, subject to conditions to be laid down therein, oblige each party thereto to accord to Investors of other parties, as regards the Making of Investments in its Area, the Treatment described in paragraph (3). That treaty shall be open for signature by the states and Regional Economic Integration Organizations which have signed or acceded to this Treaty. Negotiations towards the supplementary treaty shall commence not later than 1 January 1995, with a view to concluding it by 1 January 1998.

In Article 10 (5), the contracting parties committed to limiting exceptions to the MFN treatment to a minimum, and also agreed to progressively remove existing restrictions affecting the investors of other contracting parties, in relation to the areas covered by the Energy Charter Treaty:

(5) Each Contracting Party shall, as regards the Making of Investments in its Area, endeavor to:

(a) limit to the minimum the exceptions to the Treatment described in paragraph (3); 
(b) progressively remove existing restrictions affecting Investors of other Contracting Parties.

Furthermore, besides the general treatment provision in (2) and (3), Article 10 (7) specifically extends the MFN standard to management, maintenance, use, enjoyment, disposal (or other related activities) of investments covered by the scope of the Energy Charter Treaty:

(7) Each Contracting Party shall accord to Investments in its Area of Investors of other Contracting Parties, and their related activities including management, maintenance, use, enjoyment or disposal, treatment no less favourable than that which it accords to Investments of its own Investors or of the Investors of any other Contracting Party or any third state and their related activities including management, maintenance, use, enjoyment or disposal, whichever is the most favourable.

However, the MFN standard does not apply to the protection of intellectual property, as noted by Article 10 (10), which instead refers the subject to the applicable international agreements for the protection of intellectual property rights:

(10) Notwithstanding any other provision of this Article, the treatment described in paragraphs (3) and (7) shall not apply to the protection of Intellectual Property; instead, the treatment shall be as specified in the corresponding provisions of the applicable international agreements for the protection of Intellectual Property rights to which the respective Contracting Parties are parties.

Finally, Article 10 (12) contains an enforcement provision that mandates each contracting party to ensure that its domestic law provides effective means for the assertion of claims and the enforcement of rights with respect to investment, investment agreements:

(12) Each Contracting Party shall ensure that its domestic law provides effective means for the assertion of claims and the enforcement of rights with respect to Investments, investment agreements, and investment authorizations. 


\subsubsection{Article 12: Compensation for losses}

Investors of the contracting parties may have to face losses due to armed conflict or other wars, civil disturbances, or national emergencies. In such cases, this article guarantees the investors that their losses would be compensated no less favorably than it would be for any other domestic or foreign investor:

(1) Except where Article 13 applies, an Investor of any Contracting Party which suffers a loss with respect to any Investment in the Area of another Contracting Party owing to war or other armed conflict, state of national emergency, civil disturbance, or other similar event in that Area, shall be accorded by the latter Contracting Party, as regards restitution, indemnification, compensation or other settlement, treatment which is the most favourable of that which that Contracting Party accords to any other Investor, whether its own Investor, the Investor of any other Contracting Party, or the Investor of any third state.

Thus, we can say that Article 12 establishes a specific minimum standard of compensation for foreign investors. Furthermore Article 12 (2) reinforces the Hull standard of compensation, as mentioned in the previous chapter. That is, compensation must prompt, adequate and effective:

(2) Without prejudice to paragraph (1), an Investor of a Contracting Party which, in any of the situations referred to in that paragraph, suffers a loss in the Area of another Contracting Party resulting from

(a) requisitioning of its Investment or part thereof by the latter's forces or authorities; or

(b) destruction of its Investment or part thereof by the latter's forces or authorities, which was not required by the necessity of the situation, shall be accorded restitution or compensation which in either case shall be prompt, adequate and effective. 


\subsubsection{Article 13: Expropriation}

As it has been discussed in the previous chapter, the Energy Charter Treaty also deals with the question of expropriation. Instead of simply analyzing the article, as it was already done in the previous chapter, the proper course of action should be attempting to draw a conclusion from the examination, after summing it up.

In general, the article contains a forbiddance of expropriation, nationalization, or actions equivalent in effect to either, with any exception having to meet several criteria: to be specific, it must be for a purpose that is in the public interest, it must not be discriminatory, it must be carried out under the due process of law, and it must be accompanied by the payment of prompt, adequate and effective compensation (thus, the Hull formula). Besides this, the article also mandates the right to prompt review for affected investors.

What can we conclude from this? Well, the Energy Charter Treaty provides a rather typical protection from expropriation to affected investors. It prevents the contracting parties from enacting arbitrary expropriation or nationalization. It is also inclusive enough to cover the more insidious forms of expropriation besides direct expropriation, such as indirect or creeping expropriation. However, issues can arise from interpreting the criteria for exceptions. While compensation (Hull formula)is established in international practice, the criteria for public interest and non-discrimination are problematic. For example, if the expropriation-equivalent measure does not discriminate between the nationality of owners, but rather is based on another factor, which incidentally affects foreign investors disproportionally, the offending government could easily try to argue that the measure was not discriminatory and the exception can be applied.

Based on this, it is clear that in order for this article to be an effective method of protection against expropriation and nationalization, it must be supplemented by clear international practice and clarity of definitions. Therefore, part 4.1. will also analyze the extant arbitral practice in relation to expropriation under the Energy Charter Treaty.

\subsubsection{Article 14: Transfer related to investments}

Article 14 concerns with another issue important to foreign investors in general. The issue of transfer, and more specifically the freedom of transfer. Foreign investors often desire to 
transfer capital, profits from the investment, or other payments out of the host country. This article lays the framework for such free transfers from an international legal perspective:

(1) Each Contracting Party shall with respect to Investments in its Area of Investors of any other Contracting Party guarantee the freedom of transfer into and out of its Area, including the transfer of:

(a) the initial capital plus any additional capital for the maintenance and development of an Investment;

(b) Returns;

(c) payments under a contract, including amortization of principal and accrued interest payments pursuant to a loan agreement;

(d) unspent earnings and other remuneration of personnel engaged from abroad in connection with that Investment;

(e) proceeds from the sale or liquidation of all or any part of an Investment;

(f) payments arising out of the settlement of a dispute;

(g) payments of compensation pursuant to Articles 12 and 13.

(2) Transfers under paragraph (1) shall be effected without delay and (except in case of a Return in kind) in a Freely Convertible Currency.

(3) Transfers shall be made at the market rate of exchange existing on the date of transfer with respect to spot transactions in the currency to be transferred. In the absence of a market for foreign exchange, the rate to be used will be the most recent rate applied to inward investments or the most recent exchange rate for conversion of currencies into Special Drawing Rights, whichever is more favourable to the Investor.

(4) Notwithstanding paragraphs (1) to (3), a Contracting Party may protect the rights of creditors, or ensure compliance with laws on the issuing, trading and dealing in securities and the satisfaction of judgements in civil, administrative and criminal adjudicatory proceedings, through the equitable, non-discriminatory, and good faith application of its laws and regulations.

(5) Notwithstanding paragraph (2), Contracting Parties which are states that were constituent parts of the former Union of Soviet Socialist Republics may provide 
in agreements concluded between them that transfers of payments shall be made in the currencies of such Contracting Parties, provided that such agreements do not treat Investments in their Areas of Investors of other Contracting Parties less favourably than either Investments of Investors of the Contracting Parties which have entered into such agreements or Investments of Investors of any third state.

(6) Notwithstanding subparagraph (1)(b), a Contracting Party may restrict the transfer of a Return in kind in circumstances where the Contracting Party is permitted under Article 29(2)(a) or the GATT and Related Instruments to restrict or prohibit the exportation or the sale for export of the product constituting the Return in kind; provided that a Contracting Party shall permit transfers of Returns in kind to be effected as authorized or specified in an investment agreement, investment authorization, or other written agreement between the Contracting Party and either an Investor of another Contracting Party or its Investment.

\subsubsection{Investors' complaint under the Energy Charter Treaty}

The Energy Charter Treaty is closely related to contemporary treaties, particularly Bilateral Investment Treaties, when it comes to providing protection to foreign investments. As such, investment dispute resolution is included in the basic framework of the Energy Charter Treaty. Furthermore, the Energy Charter Secretariat may also act as a mediator under the Energy Charter Treaty. ${ }^{413}$ Besides the standard investor-state arbitration between the contracting parties should also be examined briefly.

\subsubsection{Investor-state dispute settlement in accordance with Article 26}

Investor-state dispute settlement in the Energy Charter Treaty is governed by Article 26. Article 26 (1) states that disputes should be settled amicably, if possible. If it is not settled within three months of one of the disputing parties requesting amicable settlement, the investor can choose between three options according to Article 26 (2). It can submit the dis-

\footnotetext{
${ }^{413}$ Charles Patrizia, Joseph Profaizer and Igor Timofeyev, 'GAR Chapter: Investment Disputes Involving The Renewable Energy Industry Under The Energy Charter Treaty' <http:/globalarbitrationreview.com/chapter/ 1142579/investment-disputes-involving-the-renewable-energy-industry-under-the-energy-charter-treaty $>$ accessed 20 October 2017
} 
pute to the courts or administrative tribunals of the host country. If there was a previously agreed dispute settlement procedure, the investor can initiate that. Or, the investor can submit the dispute in accordance with Article 26 of the Energy Charter Treaty.

In particular, three specific ways are provided by the Energy Charter Treaty in Article 26 (4): arbitration under ICSID, arbitration under the Stockholm Chamber of Commerce and ad hoc arbitration under UNCITRAL. In each case, the established Tribunal can interpret the dispute not only in light of the Energy Charter Treaty, but also in accordance with all applicable rules and principles of international law, as stated by Article 26 (6). Finally, Article 26 (8) reinforces the finality of arbitration awards, and the obligation of contracting parties to enforce such awards.

In conclusion, it can be confirmed that the Energy Charter Treaty uses the same method of investor-state dispute resolution as most other international treaties (particularly Bilateral Investment Treaties), by delegating the actual procedural rules to other conventions and arbitrational rulesets.

\subsubsection{Settlement between contracting parties in accordance with Article 27}

When it comes to disputes, it is possible that there is a dispute concerning the interpretation or application of the treaty. In such cases, Article 27, which deals with disputes between contracting parties, may be applicable.

According to Article 27 (1), the primary means of settling such disputes is through diplomatic channels. Should diplomatic channels prove unfruitful, and if a reasonable amount of time has passed, Article 27 (2) allows either party may, upon written notice to the other party, submit the matter to an ad hoc tribunal under Article 27. This is not universal, and some exceptions exist (such as if the parties had a written agreement that states otherwise, if one of the parties are listed in Annex IA of the Energy Charter Treaty, and so on).

This ad hoc tribunal is then constituted under Article 27 (3). The party that initiated the process appoints one member of the tribunal and informs the other of this, 30 days within the receipt of the written notice referred above, in Article 27 (2). As for the other party to the dispute, it appoints a member of the tribunal within 60 days of the receipt of the same written notice. If it fails to do so, the party initiating the procedure may, within 90 days of the receipt of the written notice, request an appointment from the Secretary-General of the 
Permanent Court of International Arbitration. The Secretary-General will then appoint the second member within 30 days of the receipt of the request to do so. As for the third member, it may not be a national or citizen of either party, and will serve as the president of the tribunal. This member is appointed by the parties mutually. If they fail to agree within 150 days of the receipt of the written notice of paragraph (2), the above-mentioned SecretaryGeneral shall make an appointment, within 180 days of the receipt of the request to do so by either party.

If the parties have no other agreement, the Arbitration Rules of UNCITRAL shall govern the dispute resolution proceedings. As for substantive law, the tribunal will decided the dispute in accordance with the Energy Charter Treaty and other applicable rules and principles of international law. The awards are final and binding.

\subsubsection{Summary of arbitral practice from the perspective of expropriation}

After reviewing the protection provided by the Energy Charter Treaty articles, and the methods of dispute resolution, it is imperative to draw conclusions from the arbitral practice surrounding the Energy Charter Treaty. This will highlight the extent of the protection provided by the Energy Charter Treaty, and how the protection is applied in actual practice. First of all, let me take a look at cases where expropriation by the host state was raised as an issue, and the foreign investor was given an award by the arbitral tribunal for the host state's breach of Article 13 (article concerning expropriation). Expropriation is perhaps the greatest danger facing foreign investors from the host state, so it should serve as an excellent litmus test for measuring the extent of protection provided by the Energy Charter Treaty to foreign investors in actual practice.

Nykomb v. Latvia, Petrobart v. Kyrgyzstan, Fuchs v. Georgia, Stati v. Kazakhstan were all cases where the host states were found liable for illegitimate expropriation, and the foreign investor was awarded damages for this expropriation. On the surface, this shows a willingness of the arbitral tribunals to utilize Article 13, and also to interpret the exceptions provision quite strictly, so as to limit how freely host states can rely on public interest to justify expropriation. But can we state that this is a universal practice of the tribunals? On the contrary, Liman Caspian Oil v. Kazakhstan and Mamadoil v. Albania clearly show the tri- 
bunals' willingness to deny foreign investors of their claim of expropriation. In these cases, even though the foreign investor raised expropriation as an issue, the tribunal refused to acknowledge that illegitimate expropriation happened. A similar case is Energoalliance v. Moldova, where the foreign investor was ultimately awarded damages, but not for expropriation as it originally tried to claim.

Therefore, we can state that the arbitral tribunals interpreting the Energy Charter Treaty tend towards a balanced form of investment protection. They are not unwilling to interpret the exceptions clause strictly and side with the foreign investor, but they are also just as likely, if the situation warrants it, to deny claims of damages based on expropriation. The tribunals thus clearly attempt to provide a reasonable extent of protection to foreign investors.

However, we cannot evade the question of enforceability. Even if the tribunal sides with the foreign investor, and acknowledges expropriation, the host state might not be willing to pay the damages. This situation happened in Hulley v. Russia and Veteran Petroleum v. Russia. Both cases concerned the defunct Yukos Oil Company, and its supposed expropriation by the Russian Federation. Even though the tribunal in both cases acknowledged that illegitimate expropriation happened to Yukos and ordered the host state (Russia) to pay damages to the foreign investors involved, the Russian Federation denied the legitimacy of these proceedings, citing political bias.

Thus, this is the chink in the armor of protection provided by the Energy Charter Treaty. Even if tribunals award damages to foreign investors, forcing host states to pay damages is a different matter. As shown by these cases, the extent of protection cannot be considered completely foolproof. It only takes one rogue state exercising its sovereignty in defiance of the arbitral tribunal to halt compensation of foreign investors. Obviously, this can have damaging effects on the host state on the long term, but such political games are still frequently played by the unaccountable and the dictatorial.

Based on the arbitral practice, we can therefore conclude that the cases provide proof for investment protection in actual practice. This protection is not just paper law, but something that tribunals actively acknowledge and use in their awards. However, neither can we say that the Energy Charter Treaty's provisions are typically interpreted in a way biased 
towards foreign investors. It is evident that the tribunals attempt to find the correctly strict or loose interpretation for each case.

\subsubsection{Conclusion}

As can be seen from the relevant Energy Charter Treaty articles, and the discussed case law, the Energy Charter Treaty plays an important role in the settlement of disputes in the energy sector. The disputes that arise in the energy sector will likely thus remain a subject of international arbitration for a long period. The demand for energy has been increasing globally, due to which foreign investment has become much more crucial to the development and the exploration of the states in possession of abundant energy resources. In this regard, the Energy Charter Treaty may provide a stable framework that also offers compulsory protection for the investors of other countries.

The Energy Charter Treaty has the ability to provide significant capital and advantages to the countries that have interests in the trade of energy products. It can also be said that the presence of the Energy Charter Treaty may have the ability to provide security to the investor of other countries. The Energy Charter Treaty can also provide resolutions for disputes between contracting parties, or disputes concerning foreign investors of contracting parties. The treatment standards of the Energy Charter Treaty have much resemblance to the practices established by the World Trade Organization, which provides a strong basis for this treaty. The Energy Charter Treaty also provides protection to investors. This protection, as shown by this segment, closely resembles the protection provided by Bilateral Investment Treaties. This is evidenced by the use of the Hull standard for compensation, or by the dispute resolution process in Article 26.

Furthermore, the theoretical protection provided by the Energy Charter Treaty is reinforced by the actual arbitral practice. As it was shown through examples, the arbitral tribunals interpreting the Energy Charter Treaty tend towards a balanced approach, leveraging the correct extent of protection, especially in relation to questions of expropriation.

Therefore, we can conclude that the Energy Charter Treaty definitely provides protection to foreign investments both in theory and actual practice. The real extent of this protection seems subject to change, as the theoretical extent can be considered average, no lesser or 
greater than the extent provided by other similar international treaties, while the arbitral practice shows different levels of strictness, based on what is appropriate in the given case.

\subsection{Comparison of compensation under the Energy Charter Treaty and compensation in general international practice}

\subsubsection{Introduction}

Based on the findings of part 4.1, I have established that the Energy Charter Treaty's level of protection given to foreign investors is comparable to similar treaties as well as BITs. I also found, that despite the apparent strictness of the expropriation clause, tribunals have interpreted the clause in a balanced manner. However, there is still one key issue that needs to be addressed, this issue is compensation. Compensation is a central element to almost all discussions and disputes about investment protection. It is inherently tied to expropriation, a typical consequence of it. Furthermore, compensation can also occur in relation to losses that fall outside the traditional form of expropriation (such as requisition of property by forces under government control, due to ongoing armed conflict). The issue therefore cannot be sidelined, and merits a separate discussion in my opinion. This is not an entirely new issue in my dissertation. Supra in Chapter 4, I have already examined the basic concepts surrounding compensation (the Hull standard, appropriate compensation, etc.). Furthermore, in the same chapter, I have also discussed the Energy Charter Treaty's position on the question of compensation.

However, what I haven't done so far is a comparison. I have examined several Energy Charter Treaty cases in the second half of Chapter 4, some of which were raised in 4.1, in relation to expropriation, but I haven't drawn any conclusions relating to them from the perspective of compensation. Therefore, the next logical step is to examine the issue of compensation in the case law of the Energy Charter Treaty, and to compare it to the nonEnergy Charter Treaty case law, to find the answer to the following questions: Are the tribunals interpreting the Energy Charter Treaty more prone to ordering payment of compensation, when compared to non-Energy Charter Treaty cases? Is the amount of compensation in Energy Charter Treaty cases more generous on average, when compared to non-Energy Charter Treaty cases or is it less generous on average? To answer these questions, I 
have devised the following method. I formulate the theoretical similarities and differences between the Energy Charter Treaty and other sources of investment protection in relation to compensation. Then, I utilize available statistics and data to reach a conclusion about how the issue of compensation is actually handled by the Energy Charter Treaty, in comparison to general investment treaty arbitration.

\subsubsection{Comparing compensation}

Before beginning the analysis and interpretation of actual practice, first it is necessary to summarize compensation as a concept. I provide the theoretical framework, a comparison from several different perspectives. Compensation covers many concepts, as already discussed in Chapter 4, but for the purposes of this segment, it shall be sufficient to only examine compensation from the perspective of customary international law, BITs and the Energy Charter Treaty. This shall serve as the basis of the practical comparison in the following.

Let me begin with customary international law. To understand how compensation works in the context of customary international law, I have to acknowledge that there is a distinction between so-called primary and secondary rules for responsibility of states for internationally wrongful acts. Violation of primary rules is the responsibility of the state, and secondary rules govern the liability of the state for breaches of primary rules. ${ }^{414}$ In short, primary rules consist of the actual obligations undertaken by the states, while secondary rules deal with whether those obligations have been breached, and what its consequences will be. So, how can I apply this to expropriation and compensation? Expropriation is considered a sovereign right of states, so in itself, carrying out an expropriation is not considered a part of the primary rules from the perspective of international customary law. Rather, the primary rules (the actual obligation) lie in the conditions of its lawful implementation. Carrying out an expropriation does not incur any international liability, but failing to meet the conditions for legitimate expropriation does. So, when applied to the current topic, the state has an obligation to compensate (primary rules), and if it fails to do so, it has an obligation to

\footnotetext{
${ }^{414}$ S.H Nikièma, 'Compensation For Expropriation' < http://www.iisd.org/pdf/2013/best_practice_compensation_expropriation_en.pdf $>$ accessed 4 November 2017
} 
indemnify the investor (secondary rules). Thus, customary international law separates the concept of compensation into compensation for lawful expropriation, and compensation for wrongful expropriation. However, the two concepts cannot always be easily distinguished from each other. In general, customary law holds the Chorzów Factory Case from 1928 to be the guiding case. In this case, the tribunal differentiated between the two forms of compensation. Compensation for lawful expropriation only covers damnum emergens, or losses suffered upon the date of expropriation, limited to the static value of the investment's assets. By contrast, compensation for wrongful expropriation goes further than mere compensation, as it contains a form of reparation, by also dealing with lucrum cessans, lost profits. In this case, the investor is not only compensated for the investment's static value, but is also given reparation for the loss of profit associated with the investment. This principle is also established by the International Law Commission Draft Articles on the Responsibility of States for Internationally Wrongful Acts. This document is generally considered an important codification of relevant customary rules. To be specific, it states that "compensation shall cover any financially assessable damage including loss of profits insofar as it is established." 415 Of course, customary international law is open to interpretation by its very nature, and so hard rules cannot be satisfyingly ascertained.

After customary international law, the next step is to discuss BITs and compensation. Instead of examining specific BITs, it would be more efficient to note the general trends that affect BITs in connection with compensation. First of all, it has to be noted that most BITs do not explicitly differentiate between direct and indirect expropriation, using a single standard of compensation for both situations. This can be highly problematic, because the scope of indirect expropriation can be quite broad, depending on who is interpreting the clauses. This breeds uncertainty and unpredictability, as in theory, every single sovereign action or decision by the state that negatively affects the investment, could be understood as a form of indirect expropriation. This is why the lack of differentiation is extremely harmful. Secondly, to compound this problem, there are typically no separate compensation standards for lawful and wrongful expropriations. Instead, BITs typically mandate one general standard for compensation, whether the expropriation was lawful or wrongful. Besides, similar interpretive issues as the ones noted previously, also raise ethical concerns,

\footnotetext{
${ }^{415}$ ibid
} 
as states which expropriate lawfully have to pay the same amount of compensation as those expropriating wrongfully. This stands in sharp contrast to the previously popular practices found in customary international law. A third trend is that BITs typically demand compensation that is either immediate or without undue delay. This usually means that the expropriating state has to assess the compensation before it actually expropriates. Therefore, states have to make very extensive preparations before expropriation, which might be unrealistic or even absurd in certain situations. Finally, BITs very frequently require that compensation for expropriation is to include interest. This can also be problematic, as the date of payment might be significantly after the date of expropriation, which of course would be the states' fault. Although, this argues that states should comply with previous trends (immediate payment of compensation); it can also lead to dramatically increased amounts of compensation. ${ }^{416}$

The final part of this theoretical examination concerns the Energy Charter Treaty. As noted previously in the work, Article 12 and Article 13 of the Energy Charter Treaty deal with the issue of compensation. Article 12 concerns itself with compensation for losses incurred outside the standard circle of expropriation, nationalization and expropriation-equivalent measures. Meanwhile, Article 13 (which deals with expropriation), has its own provisions about compensation related to expropriation. Both of these articles merit a short examination, so as to remind the reader of how the issue of compensation is handled by the Energy Charter Treaty.

First of all, let's start with Article 12. Article 12 has two paragraphs, the first of which provides a general standard of treatment in relation to compensation. To be specific:

(1) Except where Article 13 applies, an Investor of any Contracting Party which suffers a loss with respect to any Investment in the Area of another Contracting Party owing to war or other armed conflict, state of national emergency, civil disturbance, or other similar event in that Area, shall be accorded by the latter Contracting Party, as regards restitution, indemnification, compensation or other settlement, treatment which is the most favourable of that which that Contracting Party 
accords to any other Investor, whether its own Investor, the Investor of any other Contracting Party, or the Investor of any third state.

So, the paragraph first establishes an exception from Article 13. Instead, this standard is applied when the foreign investors suffers loss in connection with its investments in the host state, as a result of war, armed conflict, national emergency, civil disturbance and similar events. In these cases, the standard provides a sort of MFN and National treatment to the foreign investor, guaranteeing that the restitution, indemnification, compensation or other settlement will be handled in the most favorable manner the host country provides. This establishes a high standard of compensation for the issues covered by the article.

Moving on, Article 12's second paragraph contains a minimum standard of compensation that must be met, regardless of the first paragraph, as seen below:

(2) Without prejudice to paragraph (1), an Investor of a Contracting Party which, in any of the situations referred to in that paragraph, suffers a loss in the Area of another Contracting Party resulting from (a) requisitioning of its Investment or part thereof by the latter's forces or authorities; or

(b) destruction of its Investment or part thereof by the latter's forces or authorities, which was not required by the necessity of the situation,

shall be accorded restitution or compensation which in either case shall be prompt, adequate and effective.

It mandates that if the foreign investor (belonging to a contracting party of the Energy Charter Treaty) suffers a loss in the host state, as a result of requisitioning of its investment by the latter's forces or authorities, or because of the destruction of its investment by the latter's forcers or authorities (and it was not required by the necessity of the situation), then the investor shall be accorded restitution or compensation, which shall be prompt, adequate and effective. That is to say, in addition to the MFN standard mandated by the first para- 
graph, the compensation paid to the foreign investor must at least meet the Hull standard (prompt, adequate and effective).

Another part of the Energy Charter Treaty that deals with compensation is Article 13. Article 13 is fundamentally about expropriation, nationalization and equivalent measures, and the provisions that deal with compensation are also focused on compensation for expropriation and similar measures, as shown here:

(1) Investments of Investors of a Contracting Party in the Area of any other Contracting Party shall not be nationalized, expropriated or subjected to a measure or measures having effect equivalent to nationalization or expropriation (hereinafter referred to as "Expropriation") except where such Expropriation is:

(a) for a purpose which is in the public interest;

(b) not discriminatory;

(c) carried out under due process of law; and

(d) accompanied by the payment of prompt, adequate and effective compensation.

To be specific, Article 13 (1) (d) posits that all legitimate expropriation is to be accompanied by the payment of prompt, adequate and effective compensation. ${ }^{417}$ This provision thus establishes the same minimum standard as the one used in Article 12 (2), it being the Hull standard of compensation. The second part of Article 13 (1) mandates that such compensation is to amount to the fair market value of the investment expropriated at the time immediately before the expropriation or impeding expropriation became known in such a way as to affect the value of the investment (this is the so-called valuation date). Finally, the Energy Charter Treaty also mandates that at the request of the foreign investor, this fair market value is to be expressed in a freely convertible currency on the basis of the market rate of exchange existing for that currency on the valuation date. This compensation should

\footnotetext{
${ }^{417}$ For more information on effective compensation in general, see Zoltan Víg, Requirements of lawful taking of
} foreign property in international law (Iurisperitus Kiado, Szeged, 2016) 
also include interest at a commercial rate established on a market basis from the date of expropriation until the date of payment.

I have a few observations based on the above. First of all, the Energy Charter Treaty makes no real distinction between compensation for wrongful and compensation for legitimate expropriation. Article 13 only posits that legitimate expropriation is accompanied by compensation as described above. Implicitly, this would perhaps also apply to wrongful expropriation. As for Article 12, the actions described as a basis for compensation are not clearly categorized as either legitimate or wrongful. It can be inferred that some actions would be considered legitimate (such as actions taken as a result of national emergencies), while others wrongful (unreasonable asset seizure by military forces), but the Energy Charter Treaty itself does not concern itself with separating these categories. This reinforces the Energy Charter Treaty's apparent position that compensation as a concept is to be only categorized based on the source of the damages (expropriation or other), and not based on whether the sources themselves are legitimate or wrongful. This also applies to compensation for direct and indirect expropriation.

I note the differences between international customary law, BITs and the Energy Charter Treaty in that international customary law relies on a rather sophisticated system of compensation, even if openness of interpretation was inherent in its nature. It differentiates between compensation for direct and indirect expropriation, and between compensation for legitimate and wrongful expropriation. This practice is abandoned by both the BITs and the Energy Charter Treaty, as both uses a single standard of compensation for all four situations. While BITs and the Energy Charter Treaty are supposed to be more evolved than customary law, I can still observe a paradoxical decline in precision. This would likely be in the interest of foreign investors, as simplifying expropriation into a broad umbrella concept would aid them in seeking compensation. Priorities have also shifted. Paying for $l u$ crum cessans was associated with only wrongful expropriation in customary law, but BITs and the Energy Charter Treaty both remain rather silent on the issue, and implicitly, loss of profits became an integral part of investor claims, no matter the nature of expropriation. The clear prominence of interest in the BITs and the Energy Charter Treaty is also noteworthy. Reinforcing the conclusions of 4.1, I can state that when it comes to compensation, BITs and the Energy Charter Treaty are extremely similar in scope and nature. 


\subsubsection{Comparing practice through data}

After comparing the theoretical concepts of compensation presented by international customary law, the BITs and the Energy Charter Treaty, it is imperative to compare compensation in actual practice. I endeavor to compare investor-state dispute settlement cases in general (and in connection with compensation) to Energy Charter Treaty cases. Instead of comparing them on a case-by-case basis, I use statistics, and collated data to make comparisons. This provides a general overview of compensation in practice.

The first comparison is between 'win rates'. While on the surface, this does not directly relate to the principal question of compensation, I still need to consider the issue. This is because compensation only happens if the investor wins the case. Otherwise, there is no point in discussing compensation. So, I need to know this data to get some preliminary insight into the actual practice. So, who wins more, the claimant (investor) or the respondent (host state)? When I consider the 'win rate' of general investment treaty arbitration, it appears that foreign investors won 39\% of their cases, from 2013 to 2017. Host states won based on merits in $29 \%$ of ISDS cases, according to publically available records and $31 \%$ of the cases are won based on jurisdictional issues. In this case, respondent victory was defined as including cases which were dismissed under Article 41(5) of the ICSID Convention, as well as cases that were terminated. Claimant success includes all awards in which the respondent was found to be in breach of the treaty in question. The pre-2013 data is nearly the same, though the combined general 'win rate' (both merits and jurisdiction) of the respondent host states have slightly risen (by $4 \%) .{ }^{418}$

Let's examine the basic data and 'win rate' of Energy Charter Treaty cases as well. There is a total amount of 114 cases under the Energy Charter Treaty. 41972 of them have been brought before the ICSID, 22 before the Stockholm Chamber of Commerce, 10 before ad hoc arbitration tribunals under UNCITRAL rules, and 10 before the Permanent Court of Arbitration (which applied UNCITRAL rules). However, not all these cases are suitable for comparison, as $58 \%$ of the cases (66) are still pending. So, I have to base my conclusions

\footnotetext{
${ }^{418}$ Matthew Hodgson, Alastair Campbell, 'Damages and costs in investment treaty arbitration revisited' (Global Arbitration Review, 2017)

419،Energy Charter Secretariat'<https://energycharter.org/what-I-do/dispute-settlement/cases-up-to-18may-2018/> accessed 19 June 2018
} 
on the rest. Even among these, I can weed out those cases that were not concluded with awards. Therefore, I have 41 Energy Charter Treaty cases that ended in a final award, 4 of which were settlement agreements that were embodied in an award. Out of these 41, the tribunals found that there was a breach of Energy Charter Treaty and damages awarded (thus compensation) $36 \%$ of the time (15 cases). $10 \%$ of the time (4 cases), a settlement agreement was embodied in an award. In $5 \%$ of the cases ( 2 cases) the tribunals found a breach of the Energy Charter Treaty, but awarded no damages, thus no compensation and $27 \%$ of the time (11 cases), the tribunals found no breach of the Energy Charter Treaty. Finally, in $22 \%$ of the cases ( 9 cases), the tribunals concluded that they had no jurisdiction to hear the issue. ${ }^{420}$ Thus, I can only see a minimal difference. In general investment treaty arbitration, foreign investors win 39\% of their cases (breach was found by the arbitration tribunal). Similarly, foreign investors in Energy Charter Treaty cases win $41 \%$ of their cases (since I can only compare data collated with the same principles, I must also include Energy Charter Treaty cases where a breach was found, but no damages were awarded). Therefore, I can conclude that tribunals based on the Energy Charter Treaty are not dissimilar to the general practice, when it comes to deciding cases.

The second aspect that I need to compare is awarded damages (or compensation). In general investment treaty arbitration, I can consider several factors. Thanks to the distorting effect of Yukos (discussed in Chapter 4), the average amount awarded to successful claimant has risen from US\$76.3 million before 2013 , to US $\$ 1.08$ billion by 2017 . If I discount Yukos, the average amount awarded becomes US\$171 million post-2012. As for the median amount, the median award has risen to US\$40 million by 2017 (compared to US\$ 10.7 million prior to 2013). I also have to briefly mention claimed amounts. Excluding Yukos, the average amount claimed has risen from US\$491 million to US\$1,134 million. However (once again excluding Yukos), the average amount claimed where the claimant was ultimately successful was US\$794 million compared to US\$1,539 million in cases where the claimant was unsuccessful. ${ }^{421}$ Investors might generally overvalue their lost investments, but there is still a noticeably increased in compensation awarded.

\footnotetext{
420 Ibid

${ }^{421}$ Matthew Hodgson, Alastair Campbell, 'Damages and costs in investment treaty arbitration revisited' (Global Arbitration Review, 2017)
} 
So, how does this compare to the awards given in Energy Charter Treaty cases? The following chart should provide some visual guidance:

\begin{tabular}{|c|c|c|c|}
\hline & Claim & Award & Ratio \\
\hline Nikombvi Latia (16 Dec 2003) & $\begin{array}{l}\text { 7.097.680 Lats + specifie } \\
\text { performance }\end{array}$ & $\begin{array}{l}1,600,000 \text { Lats }+ \text { Spedific } \\
\text { performance }\end{array}$ & $23 \%$ \\
\hline $\begin{array}{l}\text { Pemohart v. Kurgutan (29 March } \\
\text { 2005) }\end{array}$ & 4.084 .652 USD & 1.130 .859 USD & $27,7 \%$ \\
\hline $\begin{array}{l}\text { EDF Invernanional S.A. v, Hargary } \\
\text { (4 Dec 2014) }\end{array}$ & Estimated US 100 million & Ever. 107 millicen & (estim) $100 \%$ \\
\hline $\begin{array}{l}\text { Kardarsopoules v. Geargia (3 } \\
\text { March 2010) }\end{array}$ & 350 million USD & 30.2 million USD & $8,63 \%$ \\
\hline $\begin{array}{l}\text { Evergealiliance v. Moldova (08 } \\
\text { July 2010) }\end{array}$ & MDL 243,577,971.11+interest & 195.547.212 ML.D+interels & $80 \%$ \\
\hline $\begin{array}{l}\text { Khom Rosources v. Mongodia (10 } \\
\text { Jan 2011) }\end{array}$ & 326 million USD & 80 million USD & $24,5 \%$ \\
\hline $\begin{array}{l}\text { Remingeon } v \text {, Ubaine (28 April } \\
\text { 2011) }\end{array}$ & 36 millson USD & 4,3 million USD & $12,5 \%$ \\
\hline $\begin{array}{l}\text { Atcomen v. Katakhttham (19 } \\
\text { December 2013) }\end{array}$ & 2,6 billion USD & 497.685 .101 USD & $20 \%$ \\
\hline 3 Ywhos Coser (18 Jaly 2014) & 114,174 bälion USD & 50,02 bollion USD & $43,5 \%$ \\
\hline Eieer v. Spain (4 May 2017) & 298 millien Euro & 128 millien Eurs & $43 \%$ \\
\hline $\begin{array}{l}\text { Aktaw Pebol Ticare A.S. v } \\
\text { Kasakhstam (13 November 2017) }\end{array}$ & 80 million USD & 22.7 million USD & $28,4 \%$ \\
\hline $\begin{array}{l}\text { Nowmengia v. Spain (1S February } \\
\text { 2018) }\end{array}$ & 61.3 mitision EUR & 53.3 million EUR & $\$ 6,9 \%$ \\
\hline $\begin{array}{l}\text { Masder Solar \& Thed Copperariet } \\
\text { U.A. x. Spain (16 May 2018) }\end{array}$ & 260 million EUR & 64,5 million EUR & $24,5 \%$ \\
\hline
\end{tabular}

1. Chart of Energy Charter Treaty cases, their claims and awards ${ }^{422}$

I can make some observations based on this data. In most of the cases above, I can see a similar discrepancy between claimed and awarded amounts. Barring a few exceptions, awarded compensation is significantly less than claimed compensation. The distorting effect of Yukos is also clear here, as both claimed and awarded compensation is significantly higher in absolute numbers than the rest of the cases. As for those, the median amount awarded in general investment treaty arbitration is also observable here. Most of the awards are not too far away from US\$40 million. Even discounting Yukos, there are some

422‘Energy Charter Secretariat'<https://energycharter.org> accessed 06 June 2018 
cases that also show disproportionate numbers, like Ascom or Eiser, especially the former. However, these cases can be considered mere outliers, fringe cases, and the general Energy Charter Treaty compensation tendency follows what was observed in general investment treaty arbitration.

\subsubsection{Conclusions}

How does compensation according to the Energy Charter Treaty compare to standard international practice? The answer is twofold, depending on the perspective. When it comes to the theoretical framework, I observe that the Energy Charter Treaty does not follow the lead of international customary law, and lacks its more nuanced approach to compensation. Of course, it cannot be said that the tribunals would not consider such elements when arbitrating and interpreting the Energy Charter Treaty, but it is still not explicitly present. The concept of direct and indirect expropriation, the differentiation between compensation for lawful and wrongful expropriation, etc. are all missing from the Energy Charter Treaty. However, in this regard, it is quite similar to BITs (despite their synchrony with general international practice), which are today the most common source of investment arbitration, and can be considered 'trendsetters' in investment protection. By this logic, the Energy Charter Treaty is not much different from other investment-related international treaties, at least in connection with how compensation is formulated by its provisions.

The practical analysis of the data supports this position. Neither the 'win rate' of foreign investors, nor the claimed and awarded compensation deviates significantly from the current norms of investment arbitration practice. Obviously, as mentioned before, there are some outliers that are disproportionate and distort some numbers, but they cannot be considered the decisive factor. Yukos, despite the importance of the cases attached to it, is still just a fringe case. Therefore, the Energy Charter Treaty is extremely similar to standard international practice in both theory and actual application. It can be considered a typical example of modern investment protection when it comes to compensation. It follows the same trends and norms that the other treaties do. 


\subsection{The Energy Charter Treaty and the "regulatory chill" effect}

\subsubsection{Introduction}

The literature on regulatory chill is not consistent, and many researchers have developed particular notions of it, which are highly dependent on the field in which a researcher applies the concept. To put it in other words, environmentalists have developed and applied the concept of regulatory chill in terms of environmental studies, which is different from the policy related or investment related notions developed by political or legal scientists and researchers alike. In spite of this, it is possible to determine specific common and core elements that are common across the fields and use that to create a definition.

In international investment law and public policy space, the concept of regulatory chill is believed to cause a negative effect on sustainable development. And hence it is understood to be restraining a nation or state from enacting some particular public policy measure or regulatory measure because of arbitration, or fear of arbitration, under the investor-state dispute settlement (ISDS) terms or provisions, therefore constraining the state in terms of its rights to regulate.

To understand "regulatory chill," it is crucial to examine the essential ingredient, that is to say, the right of a state to regulate, especially, the right to regulate in relation to sustainable development. It has to be understood that all sovereign states have the right to regulate on their territory, and it is confirmed by international instruments ${ }^{423}$ like the Charter of the United Nations, where this is specifically recognized by Article 2(7) and 2(1). ${ }^{424}$ Examining sustainable development, it can be described as a normative principle, stating that it is an obligation of the State to manage the economic, natural, and social resources with the

\footnotetext{
${ }^{423}$ It is embedded in the doctrine of sovereignty of a State to deliberate and decide on issues which essential and within the State's jurisdiction.

${ }^{424}$ Article 2 holds that- The Organization and its Members, in pursuit of the Purposes stated in Article 1, shall act in accordance with the following Principles

Article 2(7)- Nothing contained in the present Charter shall authorize the United Nations to intervene in matters which are essentially within the domestic jurisdiction of any state or shall require the Members to submit such matters to settlement under the present Charter; but this principle shall not prejudice the application of enforcement measures under Chapter VII.

And Article 2(1) -The Organization is based on the principle of the sovereign equality of all its Members.
} 
view that the same resources should be available to the present generation and future generations. ${ }^{425}$

Returning to the concept of regulatory chill, its common elements have been outlined by Shekhar: ${ }^{426}$ alteration in the application of domestic laws and regulation; a new kind of standard; bona fide nature of the laws or regulation (laws and regulations emphasize good faith); and fear or threat of arbitration. It must also be noted that the emergence of regulatory chill in policy can never be uniform. It is important to note that the response of policy makers, who have acted in public interest, which might be against the interests of a particular group of investors, against certain developments in the investment arena can cause the below stipulated types of regulatory chill:

Precedential chill: occurs when the policy makers respond to a finalized arbitration when considering future measures of public policy.

Response chill: affecting a particular regulation after the policy makers have become aware of risks related to state-investor dispute settlement.

Anticipatory chill: risk assessment that considers whether a future policy would result in state-investor disputes.

In the field of Investor-State Dispute Settlement (ISDS), it is crucial to know that there is an asymmetrical legal relationship between the investor and the state. This is guided by International Investment Agreements (IAAs), which govern the relationship between the host States and foreign investors. In as much as these agreements usually appear uninteresting, they have a major role. They play a significant task in a country's public sphere. The IIAs are used to govern foreign investment such as mining, energy, environmental, etc., which have a direct bearing on the life of citizens and the investment climate. Furthermore, since the IAAs have specific terms which govern how investments and investors have to be treated, they, to that extent, determine the laws which are enacted by the host nation in specific investment areas such as mining and energy.

Regulatory chill and ISDS is a major issue in areas such as energy and regional treaties. Therefore, there is a need to undertake proper analysis of the possible effects of future investment treaties and their negotiations in areas such as energy and environment, which are

\footnotetext{
${ }^{425}$ Kates Robert W, Thomas M Parris and Anthony a Leiserowitz, 'What is sustainable development?' Environment 47, no. 38 .

426ibid 2
} 
important aspects of public policy. The absence of explicit provisions in treaties to ensure that the host State can pursue and enact legitimate objectives in its policy, might result in the realization that sustainable policies in various investment sectors can be hindered by multiple arbitration claims. For example, the Statement of the European Union and the United States on Shared Principles for International Investment goes ahead to cement the commitment of the European Union (EU) and the United States (US) in the preservation of the mandate and authority of the State in the regulation of affairs which fall into the sphere of public interest. The same statement further advocates for increased public participation (PP) and transparency and the encouragement of responsibility in the conduct of business. ${ }^{427}$

Before diving into the specifics, it is crucial that the connection between treaty law and regulatory chill is established.

\subsubsection{Regulatory Chill and Treaty Law}

Control over the administration of treaties, compliance, and interpretation is very crucial for host nations. It should be noted that normative content in investment treaties, such as the Energy Charter Treaty, influences the interplay between regulatory space and international commitment, despite the host nations' aim for control. ${ }^{428}$

It is clear that these treaties are long-lasting in the regulatory space and mostly restrict the ability of states to cancel the treaty unilaterally. The second set of issues that are brought out by G Van Harten is that of the concern on influence and predictability of the investorstate arbitration and interpretation of investor treaties, treaty and in any arbitral proceedings. Therefore, States cannot predict the outcome of the arbitration. Even when there is converging jurisprudence on these issues, there is some level of uncertainty, and hence a degree of unpredictability in contours of regulatory space and arbitral disputes settlement outcomes. $^{429}$

\footnotetext{
427 'EC Trade, Statement of the European Union and the United States on Shared Principles for International Investment' $<$ http://trade.ec.europa.eu/doclib/docs/2012/april/tradoc_149331.pdf > accessed 8 August 2017

${ }^{428}$ Anne van Aaken, 'Control Mechanisms in International Investment Law' (2013) 409-435.

${ }^{429} \mathrm{G}$ Van Harten, Investment Treaty Arbitration and Public Law (OUP 2007)
} 
Another crucial point is administration, compliance, and interpretation of the treaty and control over these actions. Based on the experiences of NAFTA, ${ }^{430}$ states are empowered to have higher control over the interpretation of the treaty, and use authoritarian interpretation clauses. There is also the element of public policy or public interest, which can adversely affect international investment. This is especially so, when the environmental, social or economic regulations cause an increase in the costs of doing business and undermine profitable business prospects. Therefore, we see that the governments may have good reasons to undertake policy and regulatory measures. However, this may be curtailed by fear of arbitration. It goes without mentioning that there are various examples to illustrate this. Any actions enacted by the state that are justified by public policy can cause tension with investors and investment protection standards, which are embodied in the relevant investment treaties. The case of Philip Morris Asia Limited v The Commonwealth of Australia is a good example of this where a tobacco company sued Australia over the adoption of legislation to discourage smoking. ${ }^{431}$

In Vattenfall v. Germany $I^{432}$ the evidence of regulatory chill was seen in the dispute 433 where the German Government was taken to the Washington based ICSID. As the first investor-state arbitration dispute, the matter concerned the Vattenfall bid to construct a coal power plant in Hamburg-Moorburg, near the River Elbe. The Hamburg Authority then issued the company a license, which imposed some water quality standards. The company viewed this as unviable and unprofitable. The company argued that the license was in violation of the provisions of Energy Charter Treaty, especially under part 3 concerning the protection and promotion of investment. The company then went ahead and filed a claim of EUR 1.4 billion. This caused the government of Germany to weaken its environmental

\footnotetext{
${ }^{430}$ NAFTA Free Trade Commission, 'Notes of Interpretation of Certain Chapter 11 Provisions’ (31 July 2001)

${ }^{431}$ Philip Morris Asia Limited v The Commonwealth of Australia UNCITRAL, PCA Case No. 2012-12

${ }^{432}$ Vattenfall AB, Vattenfall Europe AG, Vattenfall Europe Generation AG v. Federal Republic of Germany, ICSID Case No. ARB/09/6

${ }^{433}$ The Vattenfall I Dispute Case (2009-2011) Regarding Environmental Regulations Applying to the Coal-Fired Power Plant Hamburg-Moorburg
} 
protection standards, and hence provide a favorable permit to the corporation, due the fear of arbitration and payment of inflated compensation. ${ }^{434}$

The Vattenfall dispute started in April 2009, when the company filed a suit against the German government. The arbitration was primarily about the challenge against German environmental measures and restrictions that had been imposed on a proposed EUR 2.6 billion coal-fired power generating plant that was being constructed along or near the Elbe River. The City of Hamburg is also the main reason why the investor approached the International Centre for the Settlement of Investment Disputes (ICSID), since it's the city which was responsible for confirming the environment regulations are adhered to, and the plant being near a river, public policy mandated that strict environmental factors be adhered to by Vattenfall. After the proposal by Vattenfall in 2004 to construct the plant, there was a lot of controversy among the German public. The various coalitions of political and environmental groups have proposed that the coal plant would be far larger than what was necessary for the city of Hamburg's energy requirements, and thus there would be unprecedented destruction to the environment. The argument was that smaller and more environmentally friendly alternatives would suffice. Despite the public opposition, the authorities in Hamburg agreed to a preliminary contract with the company in 2007 for the building of the plant, and this covered other environmental limits on the effect of the project on the river. The agreement was then pegged on the final permit by the Hamburg City Authorities. The Hamburg's Urban Development and Environmental Authority (BSU) proceeded to issue the company with construction permission in 2007 November, making it possible for the company to proceed with the construction of the plant in specific aspects of the project. In September 2008, the final approval was issued by the Authority containing additional restrictions on the Elbe River, such as the effect on water volume, the oxygen content, and temperature.

According to the City of Hamburg, the environmental conditions that had been stipulated in the permit were necessary due to German and European law, and furthermore, the conditions were consistent with all the restrictions for companies along the same River. The authorities vehemently explained that it was trying to make sure that the EU's Water Frame-

\footnotetext{
${ }^{434}$ Bernasconi-Osterwalder, Nathalie, and Rhea Tamara Hoffmann. 'The German nuclear phase-out put to the test in international investment arbitration? Background to the new dispute Vattenfall v. Germany (II)' (International Institute for Sustainable Development, 2012) 2-4
} 
work Directive is also adhered to. The Directive mandated that all EU members must make sure that specific levels of water quality are ensured in lakes, rivers, estuaries, groundwater and coastal water by 2015 .

In its argument, Vattenfall argued that said water regulations would have the result of making the whole plant uneconomical and impractical, and were way beyond what the two parties agreed to in the 2007 agreement.

Due to the German authorities imposing a more stringent permit on construction, the company alleged that the country had violated its international obligation under the Energy Charter Treaty, having ratified the treaty in 1977. Even though the dispute was between the local government in Hamburg and the company, the German federal government was the one being considered responsible by the company. The challenge of these regulatory measures, especially the water permit and the emission control permit, caused Vattenfall to approach the arbitration Tribunal.

After consultation between the German Government and the company, the two parties agreed and requested the arbitral tribunal to suspend the hearing of the dispute in March 2010. And subsequently, in August 2010, an agreement was reached to conclude a final binding resolution and stop the arbitration proceeding altogether. This agreement was received by the arbitral tribunal and as per the parties' request and in under ICSID Arbitration Rule 43(2) adopted the agreement and the award therein. ${ }^{435}$ Their agreement encompassed three conditions. On the first condition, German and Vattenfall agreed to enter a judicial settlement agreement, which ends the court proceeding between the Free and Hanseatic City of Hamburg before the Hamburgisches Oberverwaltungsgericht and Vattenfall with regards to the water permit issued in 2008. On the second point, the parties agreed to provide a replacement for the Hamburg Water permit, and thirdly, there was a consensus that the authorities in Hamburg give a written confirmation, stating that Vattenfall is to be released from the previous undertaking of “... set[ting] up district heating pipelines and to build and operate a discharge cooler at the Moorburg power plant".

In this case, as it has already been alluded to in this research, the main revelation that can be seen is that the result of the German government being sued is that of the government deciding to weaken the regulatory requirements, even disregarding environmental concerns

\footnotetext{
${ }^{435}$ Vattenfall v. Germany (2009), Award of 11 March 20112
} 
and policy. With the German government watering down the coal plant requirements, it directly disregarded its own law and the EU Water Framework Directive. In fact, based on the agreement reached by both parties, Germany decided to issue a permit that was less strict because it wanted to avoid the payment of hefty compensation to the investor.

Vattenfall v. Germany (II) was the second dispute against German by Vattenfall. This dispute came in the wake of the Fukushima catastrophe, which caused Japanese nuclear plants to be compromised by an earthquake, and as a result, the German government decided to phase-out nuclear energy generation and to forbid power generation in some nuclear energy power plants. The genesis was triggered by the actions of the German parliament in 2011 to abolish nuclear power energy by the year 2022. These changes were recorded in the Atomic Energy Act and culminated in controversy and public debate on the sustainability of the use of nuclear energy in the country. ${ }^{436}$

Furthermore, there was a $13^{\text {th }}$ amendment to the Act, a list of seven further legislative proposals from the German federal government to ensure that the country begins a new era of energy policy. The federal government reached out to the majority and announced the policy against the use of nuclear energy with the effect of rolling back the nuclear energy lifetime extension that had been announced in $2010 .{ }^{437}$ This regulation affected nuclear plants owned by Vattenfall and other companies, which complained about the new Atomic Energy Act. ${ }^{438}$ After the enactment of the amendment, Vattenfall threatened to obtain compensation from the German government for phasing out nuclear energy. 439

In the dispute, the amount claimed by the company from Germany was an overwhelming $€ 700$ million in investments lost. Afterwards, the company recorded that the estimated damages arising out the German amendment to nuclear energy law amounted to $€ 1.18$ billion. ${ }^{440}$ Furthermore, the company sought additional costs, such as legal fees, interests and missed future profits. Even though the case was highly confidential, it is clear that its im-

\footnotetext{
${ }^{436}$ Nathalie Bernasconi-Osterwalder, Rhea Tamara Hoffmann 'The Change in Transnational Labour and Economic Law' (Georgetown University Law School, 2013) 2-4

437ibid

438ibid 3

${ }^{439}$ Klaus Stratman, 'Vattenfall verklagt Deutschland' <www.handelsblatt.com/unternehmen/industrie/atomausstieg-Vattenfall-verklagt-deutschland/5787366.html $>$ accessed 8 August 2017
}

${ }^{440}$ Germany's new revision of the Atomic Energy Act took effect on 6 August 2011 
pact on the regulatory power of the state is high. The indication is that there are significant costs associated with regulation and protection under the Energy Charter Treaty. For instance, in Spain, it is estimated that renewable energy investors took significant hits with a regulatory change costs of the state estimated at EUR 1.7 billion.

The implication of the cases on energy investment on the power of the state to regulate and public policy are clear, from the standpoint of the two Vattenfall cases. The high costs of arbitration and compensation under the Energy Charter Treaty would most likely cause many contracting states to reconsider before implementing any public policy measure, even if sanctioned by the EU laws. Shocks have been witnessed when arbitral tribunals have awarded the investors billions of dollars under the Energy Charter Treaty, and this will surely create a regulatory chill, resulting in the selective implementation of policy to apply to local energy investors only. The provisions of Article 19.1(a) of the Energy Charter Treaty and the protection of investors are elements, which can come into conflict and handicap the state's power to regulate.

The key environmental provision of the Energy Charter Treaty is article 19.1(a):

(1) In pursuit of sustainable development [...], each Contracting Party shall strive to minimize in an economically efficient manner harmful Environmental Impacts occurring either within or outside its Area from all operations within the Energy Cycle in its Area, taking proper account of safety. In doing so, each Contracting Party shall act in a Cost-Effective manner. In its policies and actions, each Contracting Party shall strive to take precautionary measures to prevent or minimize environmental degradation. The Contracting Parties agree that the polluter in the Areas of Contracting Parties, should, in principle, bear the cost of pollution, including transboundary pollution, with due regard to the public interest and without distorting Investment in the Energy Cycle or international trade. Contracting Parties shall accordingly: (a) take account of environmental considerations throughout the formulation and implementation of their energy policies; $[\ldots]$ 
As seen by the above, the balance between the two is unfair, as investors have been able to rely on FET and indirect expropriation even in the case of Vattenfall where it could be seen that there were serious environmental concerns.

\subsubsection{The Right to Regulate - The Interplay Between Public Policy Issues and Investor Protection}

The element of government interference is engraved under Article 24 of Energy Charter Treaty, which gives States legitimate exceptions to obligations in the Energy Charter Treaty, these in themselves can act to create a conflict as any actions taken can be viewed by investors as prejudice towards their investments. The Energy Charter Treaty states that it shall not be illegitimate for a contracting state to enforce and adopt measures: (a) to advantage the local and indigenous or economical or socially disadvantaged, (b) needed to protect animal, plant and human health and life, and (c) in situations of an energy emergency. However, these exceptions are limited in application, and the case of expropriation since Article 24(1) of the Treaty holds that it is not applicable to the expropriation Article. ${ }^{441}$ Therefore, the expropriation concept is not covered by the Energy Charter Treaty regulatory exception of Article 24 , and has to be interpreted separately. So, any regulatory measures and exception under Article 24 can be interpreted to be an expropriation measure and hence cause an investor to seek a claim against a host state.

To quote Christoph Schreuer: '[Expropriation is:] any legislative action or administration action or omission attributed to the host government which has the effect of depriving, the holder of a guarantee of his ownership or control of, or a substantial benefit from, his investment, with the exception of non-discriminatory measure of general application which governments normally take for regulating economic activity in their territory.' 442

\footnotetext{
${ }^{441}$ Energy Charter Treaty Article 13

${ }^{442}$ Christoph Schreuer, 'The concept of Expropriation under the Energy Charter Treaty and other Investment Protection Treaties' $<$ http://www.univie.ac.at/intlaw/pdf/csunpublpaper_3.pdf $>$ accessed 7 September 2017
} 
Enacting legislation that favors certain local investors would cause the substantial reduction of benefits received by foreign investors, though it is a legitimate exception under Article 24. What this means is that even the enactment of Article 24 exceptions can be considered indirect expropriation, and hence cause apprehension towards the host state, resulting in regulatory chill. ${ }^{443}$ This phenomenon is seen in the Case of Pope \& Talbot v. Canada (a NAFTA case). The concept of regulatory change may make it harder for the state to regulate desirably, especially in areas like environmental protection, human rights and furthermore, comply with international obligation.

It is thus fair to argue that it doesn't matter which actions the host state intend to take, whether it is acting upon the exception under Article 24 or even indirect expropriation, the fear of costly arbitration is real. Even though full expropriation is not an issue in energy investments, most renewable energy investors have argued and relied on indirect expropriation. For instance, under the Energy Charter Treaty, primarily the Fair and Equitable Treatment (FET) has seen different interpretations, which is dangerous, as most of them have shown that public purpose is not a relevant factor- what is enough is the finding that the regulation has a substantial effect on the assets of the investor. ${ }^{444}$

In case of indirect expropriation, circumstances have decided whether state measures achieve the same impact as if it were direct. This is determined if there are substantial restrictive measures to cause the effect of "taking" the property of an investor. As above, the motive or relevance has been an issue that has been approached differently by various Tribunals, hence causing uncertainty. As the State would not know the outcome, it would fear arbitration even when enacting the so-called Article 24 exceptions. ${ }^{445}$

\subsubsection{The Recipe for Regulatory Chill}

From the above arguments, it is clear that any government conduct must be weighed properly in terms of determining any investor rights and claims that may arise. The numbers of

\footnotetext{
${ }^{443}$ Christoph Schreuer, 'The concept of Expropriation under the Energy Charter Treaty and other Investment Protection Treaties' 7. <http://www.univie.ac.at/intlaw/pdf/csunpublpaper_3.pdf > accessed 7 September 2017

${ }^{444}$ Charter Energy, 'Expropriation Regime under the Energy Charter Treaty’ (2012) Transnational Dispute Management (TDM) 9, no. 714.

${ }^{445}$ Dolzer Rudolf, Christoph Schreuer, Principles of international investment law (Oxford University Press, 2012)
} 
disputes under the Energy Charter Treaty have increased significantly to 114 cases, ${ }^{446}$ and at least 12 arbitration awards. With increased awards and arbitration disputes, there is an inherent increment in the cautious nature of the exercise of the state policing power. ${ }^{447}$ Since many EU nations have considered the advancements in the field of renewable energy a major priority, and that attached to numerous advantages, inter alia protection of the environment, economic growth, and high level of energy efficiency, such as Germany, it is clear that foreign investors may lose substantial investments from such undertakings. ${ }^{448}$ These international obligations created by the Energy Charter Treaty come into conflict with regulatory measures in terms of competing standards between the Energy Charter Treaty and the public policy measures, putting the states in a dilemma of risking arbitration and the high costs of implementation or adopting a 'wait and see' perspective. There may also be conflicts when complying with other international regulatory standards, which for instance could be determined to fall within stabilization clauses. It has been argued that this comes to where the legislative changes have the impact of increasing the costs of ongoing investment activities and projects. An example of this would be that because of tight requirements for compensation for expropriation of investor properties, as provided in the Energy Charter Treaty, and another requirement, which acts in counter to the first, by mandating the increased protection of the environment and ecosystems or even species affected by energy investments. Balancing the two competing international requirements can be challenging for the host state. As a consequence, the government that adopts measures that raise environmental and social standards, and further requires these standards to be applied to any ongoing investments projects, may need to compensate such investors based on the economic impact of the regulations and the contract between the state and the investor. ${ }^{449}$ This legal liability, fear of compensation, and uncertainty in the outcome of how many investors will seek arbitration, make it more difficult for host nations, especially those which

\footnotetext{
${ }^{446}$ 'Energy Charter Secretariat' <https://energycharter.org/what-I-do/dispute-settlement/cases-up-to-18may-2018/> accessed 19 June 2018

${ }^{447}$ UNCTAD, 'Investor-State Dispute Settlement: Review of Developments in 2014, Issue 2' <http://unctad.org/ en/PublicationsLibrary/webdiaepcb2015d2_en.pdf> accessed 17 November 2015

${ }^{448}$ Anna de Lucca, 'Renewable energy in the EU, the Energy Charter Treaty, and Italy's Withdrawal Therefrom' $<$ http://ssrn.com/abstract $=2657395>$ accessed 4 August 2017

${ }^{449}$ Cotula, Lorenzo, 'Regulatory takings, stabilization clauses and sustainable development' (2008) OECD Investment Policy Perspectives 11
} 
do not want to face high claims, to adopt regulations or even ratify any treaties which have the effect of raising environmental and social standards. ${ }^{450}$

This situation ties the hands of states, as there is little that can be done since even opting out of the Treaty does not diminish the rights of investors for 20 years. ${ }^{451}$ Alternatively, there are examples where host nations have opted to exclude the application of the regulations to the investment project to avoid arbitration and high costs. In alternative words, a state can choose to adopt these new regulations, but exempt foreign investors; hence preventing the stabilization clauses from affecting the foreign investors. As Cotula puts it, this scenario can cause complicated coherence in a state's legal framework especially for investments in spanning decades ${ }^{452}$ Even so, when this is applied under the Energy Charter Treaty, the result, whether selective regulation or regulatory chill or even withdrawing of measures, the result is the same, as it hampers states legislation and policy implementation due to fear of arbitration and costs.

Considering this under the EU and Energy Charter Treaty, several states have faced arbitration as a result of regulation: Italy, the Czech Republic, Spain and Bulgaria. ${ }^{453}$ This has caused a wave of arbitration disputes as investors seek compensation for breaches of the Energy Charter Treaty. As noted above, these changes in economic support programs relating to renewable energy market have increased exponentially, as a result. ${ }^{454}$ Simoes Fernando Dias notes that the anatomy and structure of these new cases are very different as compared to the energy-related disputes, which have been filed for arbitration in the previous years. Commentators have also expressed concerns for the reason that an investor can easily commence an arbitration process and claim that climate and environmental regulatory measures negated the very energy investment treaty and contract provisions - as such causing a risk that international energy investment agreement can lead to constraining

\footnotetext{
$450 \mathrm{ibid}$

${ }^{451}$ Energy Charter Treaty Article 47 (3)

${ }^{452}$ ibid 12.

${ }^{453}$ Simoes Fernando Dias, 'When Green Incentives Go Pale: Investment Arbitration and Renewable Energy Policymaking' (2016) Denv. J. Int'l L. \& Pol'y 45251.

454ibid 5.
} 
(regulatory chill) on climate change and environmental protection, and consequently have a significant impact on the host state's policy space. ${ }^{455}$

To put it differently, many of the aforementioned European Union nations, like Italy and Spain, started to eliminate and reduce significantly the incentives that had been introduced many years ago to attract investments in the renewable energy market. The result caused complaints from investors on the fact that the changes amounted to a reduction in the commercial viability of the assets and investments they had invested in. ${ }^{456}$ On the other side of the coin, the host states have argued that the support mechanisms which were in place, have become too popular, and hence very expensive and costly than what had been anticipated; and that they had been generous since production capital for newer technologies have reduced substantially; or even that these states can no longer sustain these initiatives because of ongoing financial difficulties. ${ }^{457}$ The main concern, however, the crux of the question, remains whether an investor is able to get compensation, or rather, seek it, if a host state that has encouraged investments through the use of support schemes, and later decides to eliminate them or reduce them after investments have been made. Again, the answer is that even in such a case, there can be a clash between investment laws and energy-related policies. ${ }^{458}$

The classical problem that is raised by these kinds of dispute under the Energy Charter Treaty is the dilemma which states face in investment arbitration, protection of public interest and investment protection: how to strike a proper balance between the host state rights to promulgate policies and regulations and the protection of foreign investments in energy under the Energy Charter Treaty, and their reliance on such regulations, which is

\footnotetext{
${ }^{455}$ See Stephan Schill, 'Do Investment Treaties Chill Unilateral State Regulation to Mitigate Climate Change?' (2007) 24(5) Journal of International Arbitration 469., Jacob Werksman et al., 'Will International Investment Rules Obstruct Climate Protection Policies? An Examination of the Clean Development Mechanism' (2003) 3 International Environmental Agreements: Politics, Law and Economics 59.

${ }^{456} \mathrm{Behn}$ Daniel, and Ole Kristian Fauchald, 'Governments under Cross-Fire: Renewable Energy and International Economic Tribunals’ (2015) Manchester J. Int'l Econ. L. 12117.

${ }^{457}$ Glinavos Ioannis, 'Solar eclipse: investment treaty arbitration and Spain's photovoltaic troubles' in Lessons from the great recession: At the crossroads of sustainability and recovery (Emerald Group Publishing Limited, 2016) 251-271.

${ }^{458}$ Rudolf Dolzer and Christoph Schreuer, Principles of international investment law (Oxford University Press, 2012) 145-149.
} 
core to their long terms investments. ${ }^{459}$ These measures, which are seen by investors as diminishing investment protection, comprises of government policy undertaken for public purposes. It is worth noting, that a host state power and function of regulating the distribution, consumption, and production of energy is a crucial element in national economic law and a matter well within the power of a sovereign. ${ }^{460}$ The novelty in the latest wakes of disputes reveal that the challenged measures have the effect of working against the protection of the environment, while in the past they would be considered as being ecofriendly. ${ }^{461}$

The increasing number of cases under the Energy Charter Treaty and the number of awards is something which leaves many European nations worried. There are many cases, and a select few will be discussed below.

Spain has more energy related investor disputes than the entire EU, even though many of the cases have not yet been decided. And a few have been decided in favor of the state; it is clear that the number of cases has been on the rise after more calls have been issued to member states of the EU to implement sustainable energy measures. The country has over 30 pending cases, after the nation undertook energy sector reforms, especially in the renewable energy sector. As a result, the number of energy investments disputes rose exponentially. The government actions included a $7 \%$ tax on all power generators revenue and subsequently reduce energy subsidies for the renewable energy sector. These actions were followed by successive foreign energy investors starting arbitration claims against the Spanish government.

Even though, there are more cases which were decided in favor of Spain, there are other decisions that went in favor of the investors. The case of Charanne and Construction Investments $v$ Kingdom of Spain $^{462}$ is one such case. The case concerned a foreign investor

\footnotetext{
${ }^{459}$ Jorge E. Viñuales, Foreign investment and the environment in international law Vol. 94. (Cambridge University Press, 2012) 17-23.

${ }^{460}$ Krajewski, Markus, 'The impact of international investment agreements on energy regulation' in European Yearbook of International Economic Law 2012 (Springer Berlin Heidelberg, 2012) 343-345.

${ }^{461}$ Nathanson Rachel An, 'The revocation of clean-energy investment economic-support systems as indirect expropriation post-nykomb: A Spanish case analysis’ (2012) 98 IOWA LAW REVIEW 863, 865.

${ }^{462}$ Charanne and Construction Investments v. SpainCharanne B.V. and Construction Investments S.a.r.l. v. Spain, SCC Case No. 062/2012
} 
from Luxembourg and its partner from Spain and the Respondent the Spanish state. The claimant had a stake in a Spanish solar power plant. The genesis of the dispute resulted from the actions of the Spanish government, undertaking reforms in the renewable energy sector. As already mentioned above, the government imposed a $7 \%$ tax on all power generated revenue and further reduced the subsidies which had been previously available for the renewable energy producers. The case is one of the first disputes in renewable energy investment in the European Union. The investor claimed that the state changed the regulation, hence affecting the project's viability and profitability. The claimant's case was premised on the reasoning that the impact of the measures which were adopted through the Spanish Government Royal Decree 1565/2010 and RDL 14/2010 had caused a significant negative economic impact on the profit margins of the Claimant, and therefore constitutes expropriation of a bigger value of the claimant's investment. ${ }^{463}$ Moreover, the legislations and amendments by the Spanish government had further eaten into the profit of the solar plants. The Claimant relied on the fact that RD 661/2007 caused losses by $8.5 \%$ and RD $1578 / 2008$ losses calculated at $10 \%$. The Spanish government's argument was based on public interest, and that both the regulatory measures RDL 14/2010 and RD 1565/2010 were reasonable and had been undertaken in the name of public policy, in a proportionate and non-discriminatory manner, and with compliance with the law and due process. ${ }^{464}$ The Spanish government also submitted that there was no breach of legitimate expectation, FET provisions under Article 10(1) of the Energy Charter Treaty and Article 10(12). What the tribunal found is that the Spanish government had not made any specific promises and commitments to the claimant that the incentives that were previously in place will be stable, and that the investor could not have expected that a renewable energy framework which has been promulgated by way of Royal Decrees, i.e., Royal Decrees 661/07 and 1578/08 could remain unchanged for the entire lifetime of the Claimant's plant. Thus, according to the arbitral tribunal, the lack of specific commitment from the Spanish Kingdom meant that there was no specific violation of legitimate expectation of the investor. Furthermore, the opinion of the tribunal pointed to the reasoning that the changes which had been undertaken in 2010 were proportional, reasonable, and not retroactive and made in

\footnotetext{
463ibid, Claim, paras. 263-265; Deloitte Report 1, p. 61; Reply, paras. 453, 467 et seq.

464ibid, PHB2 Claimants, paras. 377-378
} 
the public interest. The tribunal also held that the award it made could not be used as a decisive decision in other awards made under the Energy Charter Treaty.

Even though the Spanish government escaped a liability of over 17 million Euros, which the claimant has asked from the tribunal, the case set the ground for other cases which have been brought against the Spanish government. It is also worth noting that the technicality which made the Spanish government escape liability, through the use of Royal Decrees not creating specific commitments, was not a convincing one. In a dissenting opinion, one arbitrator, Prof. Dr. Guido Santiago, argued differently in relation to the creation of legitimate expectation. The argument reveals that specific commitment is not a true test for creating legitimate expectation:

"when an investor complies with all requirements of the legislation to be entitled to an expected and determinable benefit, subsequent disregard on the part of the State receiving the investment violates legitimate expectations."

The other case which was brought against Spain was the case of Isolux v Spain $^{465}$ which was resolved in favor of the Spanish government. In the case, the Claimant challenged the Spanish government's renewable energy policy. The Tribunal, however, rejected the legitimate expectation which the Claimant relied upon. The casing point which was alluded to by the Tribunal was that the company Isolux had only made investments after 2012, meaning that the renewable energy regulatory framework had been modified or changed a number of times by that time. This is a contradicting position as compared to the first case too. Even though the rulings were in favor of the Spanish government in both the Isolux and the Charanne cases above, there is a striking difference in jurisprudence. This should be a worrying factor for all members of the EU, as the tribunals' rulings cannot be predicted. The Charanne case was categorical that the regulatory framework as a result of Royal Decrees meant that there was no specific commitment by the Spanish government to warrant a claim of legitimate expectation. In the Isolux case, the Tribunal ruled that the rationale for the absent of legitimate expectation was the reason that the company only invested after 2012. Would it be a different case if the company invested before 2012? Would there be legitimate expectation then and what about the ruling of the tribunal on legitimate expectation? The reason that the tribunals have continuously insisted that their decisions are not

${ }^{465}$ Isolux Netherlands, BV v. Kingdom of Spain, SCC Case V2013/153 
binding and should not be applied in the determination of other disputes is a thing that should worry the governments. Even though the Spanish government won in the Charanne and the Isolux cases, there is no guarantee that these can be used as precedents. This uncertainty is most likely what influences the policy makers and law makers, now that the nation is bedridden with a fleet of arbitration disputes.

The amount of money which is claimed in the arbitration is also another factor that can cause the government to reconsider its position. For instance, in the Eiser v. Spain case, ${ }^{466}$ the foreign investor invested in a solar power plant in Spain from 2007 onwards. The power plant was to be made operational in 2012. Afterwards, the historical operation and finance costs of Eiser's investments deviated from the hypothetical effective plant standard that was prescribed by the Spanish Authorities. As a result, the company suffered revenue reduction amounting to $66 \%$, as compared to its revenue for the previous years. This amounted to a reduced value of up to EUR 4 million in the investment, while the company had invested in Spain up to EUR 130 million. As per the tribunal's ruling, the Spanish government's measures created retroactive standards in the designs, which are contradictory to the fair and equitable (FET) standard. Specifically, the tribunal argued that the 'obligation to accord fair and equitable treatment means that regulatory regimes cannot be radically altered as applied to existing investments in ways that deprive investors who invested in reliance on those regimes of their investment's value. The tribunal used the discounted cash-flow method and quantified the damage in favor of Eiser at a value of 128 million Euros.

This is the threat which all the states fear when contemplating enacting regulatory measures. This fear of being taken to the arbitral tribunal and high costs of arbitration can cause a nation to withhold a regulatory measure or cancel it altogether.

This issue is different from the classical international law point of view, where normal regulations that seek to protect the public, like human rights regulations, health and environmental sustainability measures, are primarily considered to be a part of accepted policies, and thus not included under the ambit of frowned upon expropriatory measures. This has not been the case with the jurisprudence that has continuously been set by the Energy Charter Treaty arbitral awards and decisions. This has not been the case for some invest-

${ }^{466}$ Eiser Infrastructure Limited and Energía Solar Luxembourg S.à r.1. v. Kingdom of Spain, ICSID Case No. $\mathrm{ARB} / 13 / 36$ 
ment treaty arbitration awards, which have taken the view that the proper test for any regulatory measure to giving birth to expropriation is the measuring the impact to the property. This surely causes apprehension among many states. These decisions which have developed the 'sole effects' test, whereby only the economic and financial effect of s host state's measure is used as the only consideration, have caused fear of unknown among various states. ${ }^{467}$ The implication of such a determination is that once the effect of a state's measure on the investor property is established as being sufficient, expropriation will be deemed to have been established and the state will be liable to pay compensation, regardless of the public interest behind the measures. To use NAFTA (North American Free Trade Agreement), comprised of three states which are USA, Canada and Mexico, as an example. In the Metalclad Corporation v. Mexico case, ${ }^{468}$ the action taken was the protection of the environment and ecology on environmental grounds. The act of the local government amounted to an act of expropriation according to the Tribunal; and TECMED v. Mexico ${ }^{469}$ which used the same principle of 'sole effects.' There is also another jurisprudence which developed in the case of Methanex v. the United States. ${ }^{470}$ Shockingly, the Tribunal chose a different approach from the Metalclad and TECMED cases. The view taken was cementing the policy power of exemption and hence precluded the claim brought against normal measures and regulations from being considered as expropriation. This diverging jurisprudence, according to Aaron Cosbey and other ${ }^{471}$ has a far-reaching effect and scope to the powers of the state to regulate as it is uncertain how the arbitral tribunal would interpret any dispute and this has become a public interest issue hence encouraging regulatory chill. The concern from a public interest perspective is that regulators who are held liable for their impacts on investors will not regulate to the extent that they should (the "regulatory chill" argument). ${ }^{472}$

\footnotetext{
467ibid 14-15

${ }^{468}$ Metalclad v. Mexico, (ICSID Case No. ARB (AB)/97/1)

${ }^{469}$ TECMED v. Mexico, CASE No. ARB (AF)/00/2, 29 May 2003

${ }^{470}$ Methanex v. the United States, NAFTA Chapter 11 Arbitral Tribunal, 7 August 2002 and 3 August 2005

${ }^{471}$ Cosbey Aaron, Jennifer Ellis, Mahnaz Malik and Howard Mann, 'Clean energy investment: project synthesis report' (International Institute for Sustainable Development, Winnipeg, 2008) < http://www.iisd.org/publications/ pub.aspx?id=997> accessed 8 August 2017

472ibid 15
} 
This threat to being taken to arbitration is real even if the actions of the state have a good and sound justification under public policy measures. It is no wonder that there have been protests all over the EU that the Energy Charter Treaty and others like the Transatlantic Trade and Investment Partnership (TTIP) ${ }^{473}$ cause a threat to the environment, democracy and labour standards. ${ }^{474} \mathrm{I}$ shall deal with these threats to the environment only briefly, in order to not dilute the focus of the dissertation. While it is a worthwhile subject to explore, I believe that the dissertation should place its emphasis on the investment aspects, with only supplementary help from other fields.

Back to the topic at hand, the changes in the regulatory framework of energy investment could have a major effect on what seemed to be an unstoppable move to creating a lowcarbon model of energy development. Hence jeopardizing the sustainability and credibility of renewable energy measures and creating more uncertainties in the sector. ${ }^{475}$ These, of course, could cause a shift or laxity in state policy as a result of the chill and hence affect support for renewable energy in future and present. It could also be argued that years ago many investors claimed that governments had favored environmental friendly measures which were in a way framed in a manner that disadvantaged investments, the current trend of disputes in the wake of states limiting economic investment are geared to allowing encouragement in investing in new and renewable energy markets. This creates a chill as states are being tied down by investors who do not want to move to the new kind of production matrix. ${ }^{476}$

Even though only one award had been rendered by the tribunals relating to alteration of economic government support programs in the renewable energy sector. The upsurge of cases indicates that there is a clear path of increased arbitration by investors in the EU.477

\footnotetext{
${ }^{473}$ Akhtar Shayerah Ilias, and Vivian Catherine Jones, 'Proposed Transatlantic Trade and Investment Partnership (T-TIP): In Brief’ (2014) Volume 24, Number 1/2. Current Politics and Economics of Europe 111

${ }^{474}$ Sampallo Sebastian, 'Investor-state dispute settlement in the TTIP-A fair dispute resolution mechanism or the bane of democracy?’ (2016) 5.

${ }^{475}$ European Commission, Energy 2020 - A Strategy for Competitive, Sustainable and Secure Energy, COM (2010) 639 final, of November 10, 2010, 9

${ }^{476}$ Jorge E. Viñuales, Foreign investment and the environment in international law Vol. 94. (Cambridge University Press, 2012)

${ }^{477}$ Simoes Fernando Dias, 'When Green Incentives Go Pale: Investment Arbitration and Renewable Energy Policymaking' (2016) Denv. J. Int'l L. \& Pol'y 45251.
} 
On top of that, the arbitral tribunals are not bound to follow the established case law precedents, and the transparency has been argued to be patchy at best. In addition, the substratum of obligations in the Energy Charter Treaty has been revealed to be a bit problematic, and this has been shown by two Energy Charter Treaty cases including the aforementioned case of Charanne and Construction Investment v. Spain, and there is a failure of the cases under the Energy Charter Treaty to reveal any point of law that is at issue in the disputes and of course this goes to the root of transparency in the arbitration process. In as much as UNCTAD 478 has agreed that FET has been defined in various Tribunals as "a State's obligation to act consistently, transparently, reasonably, without ambiguity, arbitrariness or discrimination, in an even-handed manner, to ensure due process in decision-making and respect investors' legitimate expectations."

It has been revealed that the interpretation of this definition has been chaotic and ranged from simple issues like procedural fairness and proceeded to ensuring that there is a freeze on the regulatory measures undertaken by a host state and affecting the investor.

As much as an investor can smile about these arbitral awards and Energy Charter Treaty provisions, states which seek to comply with climate change and environmental management have less to smile about. The implications of these arbitral awards challenging legitimate public interest measures are seen as disruptive. A case example is the TransCanada v. $U S A^{479}$ which even though not under the Energy Charter Treaty, shows the disruptive nature of these arbitral claims. In the case, the denial of oil sands pipeline permit by the state was challenged as being expropriation or against the FET. Other environmental regulations have been faced with challenges like in the Lone Pine v. Canada ${ }^{480}$ and the Rockhopper v. Italy. ${ }^{481}$

As mentioned above, in 2016 January, a tribunal determined on that the host nations regulatory measures were valid; this was in the case of Charanne and Construction Investment

\footnotetext{
478 UNCTAD, 'Fair and Equitable Treatment- UNCTAD Series on Issues in International Investment Agreement II' < http://unctad.org/en/Docs/unctaddiaeia2011d5_en.pdf > accessed 7 August 2017

${ }^{479}$ TransCanada Corporation and TransCanada PipeLines Limited v. The United States of America, ICSID Case No. ARB/16/21

${ }^{480}$ Lone Pine Resources Inc. v. The Government of Canada, ICSID Case No. UNCT/15/2

${ }^{481}$ Rockhopper Italia S.p.A., Rockhopper Mediterranean Ltd, and Rockhopper Exploration Plc v. Italian Republic, ICSID Case No. ARB/17/14
} 
v. Spain. Even though the decision gives some insights on the crucial investment protection standards and how the tribunal would most likely interpret the same in the case of a dispute, it fails to outline binding precedents. The implication being that other tribunals have to make sure that they balance the rights of a state against the investor expectations. This has to be used by looking at the regulations and the surrounding public interest and according to the circumstances which surrounded the case. As this leads to diverging opinions on it is clear that investor protection will be based on the prevailing circumstances and case by case, hence creating a high level of uncertainty. ${ }^{482}$ The mode of approach undertaken by various arbitration to perhaps similar issues would vary significantly, and create higher uncertainty. ${ }^{483}$ This lack of absolute certainty leads to questions of the necessity of creating crucial investment regime concerning low-carbon energy investment climate, hence the element regulatory dilemma.

There has been massive media outcry in various EU nations like Germany, which has spanned public debate and criticism for investor-State Dispute Settlement and regarded as an unfair and undue limit to a State's sovereignty and the power to legislate. ${ }^{484}$ In the EU, in connection with the Energy Charter Treaty, the German nuclear plant policy is one such example of these disputes.

\subsubsection{Conclusion}

Based on what was discussed, the primary goal of Energy Charter Treaty is geared towards ensuring that investments in energy are protected using international standards. The result of this is that the Energy Charter Treaty can have a huge impact on regulations touching on the environment and policies in many EU states including Germany, Italy, and Spain. This is true for those regulations which have a negative impact on the foreign investors, and they can be put under litigation in the international tribunals and challenged on the grounds

\footnotetext{
${ }^{482}$ Cameron Peter D, 'Stability of Contract in the International Energy Industry' (2009) 27, no. 3 Journal of Energy \& Natural Resources Law 305-332

${ }^{483}$ Condon Bradly J., and Tapen Sinha, The role of climate change in global economic governance (Oxford University Press, 2013) 93

${ }^{484}$ Bernasconi-Osterwalder, Nathalie, and Rhea Tamara Hoffmann. 'The German nuclear phase-out put to the test in international investment arbitration? Background to the new dispute Vattenfall v. Germany (II)' (International Institute for Sustainable Development, 2012) 1-2
} 
of 'fair and equitable treatment', or an investor can seek compensation for indirect expropriation. This causes a permanent tension between public welfare interest and investor rights under the Energy Charter Treaty. In principle, the arbitral tribunal can consider public welfare in its determination, but the investor-state arbitration is focused mainly on the interests of the investor, and hence the investor-state dispute is used as a tool for shielding the investors from political risks.

In that regard, the rights given to foreign investors in many countries are higher and more demanding. In fact, in countries like German, Spain, and Italy, it has been argued that rights under the Energy Charter Treaty surpass the protection of the national law like in the case of German Basic $\mathrm{Law}^{485}$, which stipulates a balance of public interest and the state's role as a guarantor that these rights are well-balanced.

If an investor starts an action and the arbitral tribunal decides that the investor protection rights and standards under Energy Charter Treaty have been infringed, a particular state can be required to pay a hefty amount in terms of compensation. These mere threats of a claim of arbitration cause states to roll back on its intended promulgation of environmental standards, regulatory measures to protect the ecosystem and the environment. This kind of effect, a pre-emptive action, acts as a benefit to the foreign investors but to the detriment of the common good (chilling effect).

It has been shown that even if a state has two competing obligations one under the EU law and one under the Energy Charter Treaty, the Energy Charter Treaty obligations would primarily take the leading position in the case of Germany. The selective application is also another manifestation of regulatory chill under the Energy Charter Treaty, as states are more likely to apply legislations in a selective manner favoring the foreign energy investors at the expense of its national law, to avoid arbitral proceedings and the payment of hefty compensation.

Even though the other parties to the treaty have not shown any reluctance, it would be a significant development to witness what unfolds, and the next steps that Spain will undertake should the majority of the investors succeed in their arbitral claims. Even though jurisprudence is developing, and a nation like Germany has favored applying its legislations selectively, the future of Energy Charter Treaty holds a high chance of regulatory chill giv-

${ }^{485}$ The German Constitution: Grundgesetz 
en the conflict between the Energy Charter Treaty itself, the environmental conservation policy and laws in the EU.

However, regulatory chill is not easy to prove, and requires a significant length of time before its effects can be measured. In any case, it is the task of decision-makers to ensure that the public interest is protected from international corporate and other business interests, which requires a clear commitment to pursuing public interest over economic gains and reject the chilling effect caused by the factors discussed in this part of the dissertation. 


\section{Iraq and the Energy Charter Treaty}

Last to be covered is Iraq. When it comes to energy resources, Iraq occupies a prominent place as one of the most important oil exporters in the world, ranking $3^{\text {rd }}$ in crude oil exports worldwide. ${ }^{486}$ However, it is also a country with a difficult political climate, fraught with tension, and as explained in the beginning of the dissertation, one that could significantly benefit from foreign investment in their energy sector and infrastructure. After the fall of the pre-2003 regime, Iraq stands at the crossroads, as internal conflict and disagreements hamper efforts to rebuild and modernize. Due to the political situation, Iraq is also strongly in the United States of America sphere of influence, and this has an undeniable effect on domestic politics and economic policies as well.

Given the domestic situation, becoming a part of the Energy Charter Treaty would further help with the stability of the country. Foreign investors look for stability when deciding where to make their investments, and through the Energy Charter Treaty, Iraq could reinforce the image of stability. Therefore, the Energy Charter Treaty would make Iraq more attractive to foreign investments, and thus help in the development of the country towards a more prosperous future.

As mentioned early in the dissertation, Kurdistan Region is an autonomous region in Iraq, and an area which could also significantly benefit from accession to the Energy Charter Treaty. Foreign investment attracted to the region could fuel an economic boom, which would ensure a steady increase in the economic sustainability. Due to the nature legal framework and political agreements in Iraq, the Kurdistan Region is permitted to establish its own investment law, which it has established in 2006 and an important factor from the perspective of foreign investors. It is necessary here to briefly discuss the 2006 law of the Kurdistan Region.

The first issues to be addressed are definitions. In Article 1, the Law on Investment in Kurdistan Region defines the most important terms in a rather succinct manner. For the purposes of this section, the most important definition is the investor. According to Article 1 , the investor is a "natural or artificial person, whether a local or a foreigner, who invests

\footnotetext{
486'CIA World Factbook'<https://www.cia.gov/library/publications/the-world-factbook/rankorder/ 2242rank.html> accessed 25 February 2018
} 
his funds in the [Kurdistan] Region in accordance with the provisions of this Law."487 Therefore, the law covers both natural and legal persons as well, but the definition otherwise refers to the rest of the Law on Investment to fill it with actual content, besides the general notion that the investor is someone who invests its funds.

In this sense, it would also be imperative to briefly mention Article 2, which explicitly lists what projects (approved by a regional governmental investment board) are eligible to be covered under the Law of Investment. The list includes a wide range of fields, such as manufacturing, agriculture, tourism, healthcare, education and even free zones. ${ }^{488}$ It is essential to note that the law does not provide blanket protection to all foreign investors, instead only foreign investors whose projects fall into these categories, and approved by the Regional Government's Investment Board, are covered under the Law of Investment. This means that any foreign investor who would seek the protection of the Law of Investment, must negotiate with the local authorities, specifically the government investment board, before engaging in any project.

Another essential question, when it comes to laws on foreign investment is the treatment standards of the foreign investors and their investments. For this, the Kurdistan Region's Law of Investment refers to Article 3, which provides national treatment and guarantees foreign investors full ownership of their capital invested in the Kurdistan Region. ${ }^{489}$ That is, foreign investors covered under the scope of the Law of Investment, and their investments, are afforded the same treatment by the government as domestic, national investors and their investments in the Region. By guaranteeing full ownership of capital for the foreign investors, the Law of Investment excludes the possibility that foreign investors would be required to co-own their investment with domestic state-owned corporations or similar schemes.

However, it should be noted, that the Law of Investment does not mention the most favored nation treatment standard. This means, that in case either Iraq, or potentially the Kurdistan Region signs a Bilateral Investment Treaty (BIT), or makes a separate agreement

\footnotetext{
${ }^{487}$ Article 1 of Law no. (4) of 2006 of the Kurdistan Region - Iraq <http://cabinet.gov.krd/p/p.aspx? $\mathrm{l}=12 \& \mathrm{~s}=020000 \& \mathrm{r}=315 \& \mathrm{p}=293>$ accessed 1 March 2018

${ }^{488}$ Article 2 of Law no. (4) of 2006 of the Kurdistan Region - Iraq <http://cabinet.gov.krd/p/p.aspx? $\mathrm{l}=12 \& \mathrm{~s}=020000 \& \mathrm{r}=315 \& \mathrm{p}=293>$ accessed 1 March 2018

${ }^{489}$ Article 3 of Law no. (4) of 2006 of the Kurdistan Region - Iraq <http://cabinet.gov.krd/p/p.aspx? $\mathrm{l}=12 \& \mathrm{~s}=020000 \& \mathrm{r}=315 \& \mathrm{p}=293>$ accessed 1 March 2018
} 
with an individual foreign investor, the foreign investors and investments covered under this Law of Investment would not have access to the same benefits. Obviously, this would only become an issue if the special treatment provided in these cases was privileged when compared to the treatment of national, domestic investors and their investments.

Another important part of the law is Article 8, which states the foreign investor's obligations. These obligations require close cooperation with the Governmental Investment Board from the foreign investors, not just when starting the investment project, but throughout the entire process. These obligations also require foreign investors to respect local environmental standards, and to offer proper training to staff employed in the investment project. ${ }^{490}$ This can be interpreted as the regional government seeking to ensure close oversight over the projects of foreign investors. It should also be noted, that these obligations are worded in a very short manner, and the actual substance of several obligations is either not strictly defined at all, or refers to other laws of the region to fill it with content. Finally, it should be mentioned that the Law of Investment does not cover the issue of expropriation at all. This is a major oversight, as while the Law of Investment provides a degree of protection equal to national, domestic investors, it does not guarantee protection from expropriation explicitly, nor does it deal with the issue of compensation. For foreign investors, these questions are extremely important and one which can dampen or hamper the intended goal of this legislation: that is, to attract foreign investors to the Kurdistan Region.

Based on what was discussed above, it can be concluded that while the Law of Investment is a definite step in the right direction, and most likely to encourage foreign investors to invest, it still has some deficiencies. Namely, the somewhat vague terminology, the excessive referral to other regional and national laws, the lack of the most favored nation treatment standard, and the fact that the Law of Investment does not deal with the issue of expropriation and compensation in an adequate manner. Therefore, it seems logical to view that the Kurdistan Region could benefit from Iraq joining the Energy Charter Treaty, as the provisions of the Treaty provide a higher level of protection to foreign investors and their investments than the current local law on the issue and likely to contribute to further investment in the region.

\footnotetext{
${ }^{490}$ Article 8 of Law no. (4) of 2006 of the Kurdistan Region - Iraq <http://cabinet.gov.krd/p/p.aspx? $\mathrm{l}=12 \& \mathrm{~s}=020000 \& \mathrm{r}=315 \& \mathrm{p}=293>$ accessed 1 March 2018
} 
In any case, if Iraq and the Kurdistan Region join the Energy Charter Treaty, its situation will be similar to other energy exporting countries who are already contracting parties of the Energy Charter Treaty. Namely, the question of transit would also likely be central to Iraq, while Article 18, guaranteeing sovereignty over the natural resources would also be of critical importance. In fact, entering the Treaty would be beneficial simply because it would ensure the protection of natural resources, and prevent their misuse by foreign interests. 


\section{Conclusions}

The Energy Charter Treaty has accumulated much of its interpretation due to the jurisprudence found in arbitral awards. Any forthcoming contracts, treaties or agreements related or relevant to the Energy Charter Treaty would also build upon the foundation of accumulated legislation brought forth by the Energy Charter Treaty. The Road Map for the Modernization of the Energy Charter Process, which was agreed on in 2010, also makes mention of mention the Energy Charter Treaty by stating that its "investment provisions should remain untouched in their fundamentals." Furthermore, the International Energy Charter of 2015, mentioned in Chapter 1, was also significantly influenced by the Energy Charter Treaty and can be considered as a successor to it (though the Energy Charter Treaty still covers significantly more details, and has different signatories than the much shorter International Energy Charter, which has a more declarative character).

After reviewing the history and parties of the Energy Charter Treaty, the structure and content of the Treaty, examining a number of key cases related to it, answering the various questions posed at the beginning of the dissertation, and analyzing the Energy Charter Treaty from the perspective of energy exporting countries both with select examples, and from a general perspective, we can come to a conclusion regarding the Energy Charter Treaty.

First, as discussed in the historical sub-chapter, the Energy Charter Treaty is ultimately a product of its time, a creation of the pervading international zeitgeist of the nineties and its framework designed with Europe-centric East-West relations in mind. Its goals and purpose were to ensure mutual prosperity through economic symbiosis in the energy sector, once again characteristic of the optimistic outlook of the nineties, where after the fall of the Soviet Union, and the so-called "Second World", the old Cold War outlooks of paranoia and distrust were temporarily shunted off in favor of starting anew.

However, as mentioned earlier in the dissertation, this was not purely an act of altruism on the part of the West as behind the Energy Charter Treaty there were serious financial and economic interests. The countries east of the now non-existent iron curtain were ripe with opportunity as they usually had massive reserves of natural energy sources, but lacked the infrastructure, technology and most importantly, the capital, to properly exploit and utilize these resources. Therefore, the West could provide what these countries lacked and ex- 
change its own energy security needs would be secured. This was theoretically a relationship of mutual symbiosis, with the help of copious amount of foreign investment.

Despite these promising beginnings, the dissertation later explained that the Energy Charter Treaty's structure and framework was not preferable to everyone, especially to Russia. The way the ECT was construed primarily benefited energy importer countries, who could bypass obligations that energy exporters like Russia could ill-afford. Furthermore, the treaty never truly resolved the question of transit properly, which is of critical importance to energy exporters, as explained in Chapter 1 and Chapter 6.

Furthermore, the dissertation also examined the Energy Charter Treaty from the perspective of other energy exporter countries, as shown in Chapter 3. Only some of these countries belonged to the Soviet bloc during the Cold War, thus we have to consider how they fit into the paradigm established early on in the dissertation. The answer is rather simple. While it is true that several of these countries were neutral parties during the decades of the Cold War, or rather, proxies of the two sides wrestling for control over them, their situation was still fundamentally altered by the end of the Cold War. Without the constant threat of communist uprisings and other power plays, the foreign investors of the West could finally look upon these countries and make long-term, sustainable investments. This can also be considered beneficial from the perspective of these energy exporting countries as well, since they lacked capital, infrastructure and expertise, much like countries of the Eastern Bloc. But it's important to note, that although the proxy wars have mostly ended between the two powers, these regions were still rather unstable, and the Energy Charter Treaty could be seen as a potential way to stabilize these areas of the world, if only from the perspective of the energy sector. Therefore, these former Third World energy exporters can indeed be concluded as a significant element when discussing perspectives and paradigms arising from the ECT.

What is the conclusion that can be drawn from what was discussed above? For energy exporting countries within the Energy Charter Treaty, the treaty has seemingly been an excellent way to accrue foreign investments and put on an air of stability, while also ensuring control over their natural resources and providing a means of ensuring stable transit. This latter element is crucially important to landlocked countries or countries without access to 
sufficient seaports in general, as these must rely on the beneficence of third countries to keep their pipelines and other means of transport safe and undisturbed.

However, such measures might not prove sufficient, as explained in the dissertation. The transit issues cannot be said to be completely solved, as Russia's peculiar issues with the Energy Charter Treaty demonstrated it. Furthermore, the potential withdrawal of certain transit countries (such as Russia itself) could prove detrimental for other Energy Charter Treaty countries that are exporters, and rely on those countries for safe transit of their energy resources. A good example of this is Kazakhstan as explained in detail in Chapter 5. And even so, the transit system established by the Energy Charter Treaty cannot be considered as anything more than rudimentary.

Moving on, let's cover the advantages. As it has been mentioned frequently in previous parts of the dissertation, the element that most interests energy exporting countries when considering the signing and ratification of the Energy Charter Treaty, is the notion that doing so will help in attracting foreign investors and their investments. As we have seen from the examples shown by the dissertation previously, many energy exporter countries are also developing countries, which require foreign capital and potentially technical expertise to make use of their abundant natural resources, energy resources in this case. This is, because they lack the domestic capital necessary to achieve these same results. For them, the attraction of the foreign investor and his investment is an almost irresistible lure. When talking about disadvantages later in this sub-chapter, we will examine whether such attitudes are justified or not.

But why is the Energy Charter Treaty considered a good pathway to attracting foreign investment? This is due to a simple reason. When making their investments, the foreign investor takes into account two aspects: the profitability of such an venture and whether his investment would be in a potential risk of expropriation or worse. For the first aspect, the energy exporting countries naturally provide a fertile ground with their significant reserves of natural energy resources to be extracted, potentially processed then exported.

The second aspect is the more difficult one, since developing energy exporting countries often have issues with internal stability, rule of law and such factors. Therefore, for a foreign investor, investing in such a country has a high risk, because not only do they rely on 
the uncertain whims of the local ruling elite (as internal laws are less reliable and can be prone to sudden shifts and changes), they must also be wary of potential civil tensions in the larger population. Hence, energy exporting countries must find a means of establishing that domestic stability that foreign investors crave. And since domestic measures are often seen by foreign investors as not very trustworthy, signing and ratifying a treaty like the Energy Charter Treaty is a prime way to ensure potential foreign investors that their investments will be treated in a consistent manner that obeys the rule of law. Therefore, we can easily see why one of the Energy Charter Treaty's primary benefits for energy exporters is its ability to attract foreign investors.

Let's consider the other advantages of the Energy Charter Treaty for energy exporting countries. First, we should mention the question of transit. As referred to earlier in the dissertation, transit is an issue close to the heart of many energy exporters. This is especially true for countries that rely on pipelines to export energy (natural gas typically), which usually also cross third party countries besides the target importer. For landlocked countries, this is also true, as lack of seaports can make the exportation of energy troublesome, and nearly impossible to do without the cooperation of the countries between the exporter and the importer. In general, the relationship between these three sides is often problematic and uncertain. Shifts in domestic politics, foreign policies or geopolitical strategies can cause all manners of issues to these arrangements hence the Energy Charter Treaty. While the Treaty is not perfect when it comes to the issue of transit (as showcased by the situation concerning the Russian Federation and the Energy Charter Treaty, detailed earlier in the dissertation), it still provides a somewhat stable ground for a mutually beneficial transit system. By joining the Energy Charter Treaty, the energy exporting countries could access a more stable international energy transit system than what traditional diplomacy can provide.

Another advantage that should be noted is Article 18 of the Energy Charter Treaty. As mentioned previously in the dissertation, this article safeguards the energy exporting country's sovereignty over its natural resources, which naturally includes energy resources. Being party to an international treaty could potentially serve as a good way to preclude the possibility of domestic leadership making shortsighted decisions regarding its own natural resources. Thus, signing and ratifying the Energy Charter Treaty is a good way to avert 
chances of such a bad decision being made, since sovereignty is guaranteed to contracting party countries.

However, the Energy Charter Treaty has its fair share of potential downsides that should bear mentioning. First of all, there is a principal issue with how the Energy Charter Treaty itself was set up. As mentioned before in the dissertation several times, the Energy Charter Treaty is ultimately a result of energy importer needs and wants. The formulation of the treaty was thus guided more by what the energy importer countries required, rather than what was in the best interest of energy exporting countries. This possibility is substantiated by multiple factors, such as the Russian Federation's eventual withdrawal from the Energy Charter Treaty due to irreconcilable differences, as extensively detailed in Chapter 1. Furthermore, several other energy exporter countries have stayed away from the Energy Charter Treaty, often only being observers instead of full contracting parties. It can be easily concluded that the Energy Charter Treaty was not exactly in the best interest of these countries, despite the benefits such an arrangement would offer, as described above.

In a similar vein, signing and ratifying the Energy Charter Treaty severely restricts an energy exporting country's flexibility when it comes to making decisions in its energy sector. This is a natural consequence of having an international agreement regulate issues that previously belonged to domestic control. By opening up their countries to the terms and provisions of the Energy Charter Treaty, the energy exporting countries risk being tangled in a legal construct beyond their control, with potentially costly and harmful results.

In connection with what were described above, there are issues with equality between contracting parties, as particularly showcased by the Russian Federation - European Union dispute surrounding the Energy Charter Treaty. As mentioned before in Chapter 1 when describing the Russian dispute, for many energy importing countries, particularly members of the European Union, it is easy to circumvent certain provisions of the Energy Charter Treaty, which still apply to energy exporters, such as the Russian Federation. This fundamental imbalance is probably a result of how the Energy Charter Treaty was primarily drafted with the interests of western energy importing countries in mind.

And in reverse of what were discussed as potential advantages, the question of transit, and the issue of natural sovereignty can also be viewed from a more negative standpoint. The Energy Charter Treaty's transit provisions are clearly not fully sufficient and leave poten- 
tial for trouble, as exemplified by the decade-long issues the Russian Federation had with the provisional application of the Treaty, in relation with the question of transit. It can be argued that for energy exporting countries, such a faulty legal construct might not merit enough benefits to consider joining the Energy Charter Treaty for this reason.

Furthermore, it can be easily rationalized, that although Article 18 explicitly guarantees national sovereignty over natural resources in an energy exporting country, such a provision might not be adequate enough to serve its primary purpose. In defense of foreign investor's interests, such a principle can still be circumvented, or if that is not possible, the price of adhering to the principle might be too high for the energy exporting country to pay. Hence, this benefit is also of dubious value to an energy exporter.

In general, we can see that there are several advantages and disadvantages to the Energy Charter Treaty from the perspective of energy exporting countries. It can also be concluded that these are often the opposite sides of the same coin. A provision that is theoretically beneficial can also be understood as potentially disastrous. It seems prudent then to consider this situation, before ultimately passing judgement on the Energy Charter Treaty. As both positives and negatives of the Energy Charter Treaty have been weighed, my own opinion on the issue must finally come forth. Deciding whether the ECT was a mistake or an advantage for energy exporting countries is a difficult task. As shown by both, the theoretical framework, the case law, and the practical considerations from the perspective of energy exporters, the Energy Charter Treaty's effects are difficult to gauge and are extremely multi-faceted. Therefore, in the my opinion, the sensible solution would be for each energy exporting country considering becoming a contracting party in the Energy Charter Treaty, to weigh the specific advantages and disadvantages of the Treaty before committing to it or abstaining. The given country might have a dire need of foreign investment, or it might have enough domestic capital or possesses other attractive factors to draw in investors. Transit might have already been solved, or it might be an urgent question. Is the country confident in its ability to enforce its sovereignty over its natural resources? These problems and questions must be individually considered before the country makes its decision.

In my opinion, the Energy Charter Treaty cannot be simply classified as either a truly beneficial treaty, nor can it be dismissed as something chiefly concerned with serving the inter- 
ests of energy importing developed countries. Instead, I urge all readers to see the Energy Charter Treaty with all its nuances, with both the potential benefits and hindrances it can bring to an energy exporting country. It is impossible to draw a general conclusion about the overall effects of the Treaty; therefore, specific conclusions must be drawn on a country-by-country basis.

As outlined in the introduction, the question becomes that what can be concluded in connection with Iraq, and the Kurdistan Region of Iraq in specific. As mentioned before in the dissertation, Iraq, after its opening to the world economy, has significant energy resources, but is reliant on procuring foreign investment to develop proper exporting capabilities. As it has been reiterated multiple times, the most important factor for foreign investors is stability and legal guarantees that are actually enforced. When it comes to domestic law, as previously mentioned, Iraq's law is still far too inadequate to assuage the concerns of the investors. Furthermore, neither Iraqi law nor the Kurdistan Region's Law on Investment (that was discussed in-depth in Chapter 5) provides much when it comes to expropriation. And as we can see from the dissertation, expropriation is an overpowering concern for foreign investors.

Another issue that arises, in relation to the Kurdistan Region, is transit, as mentioned before, in the introduction. Pipelines coming from the Kurdistan Region must necessarily move through Turkey, and thus exporters are reliant on Turkey's goodwill, in lieu of proper treaties.

Thus, the adoption of the Energy Charter Treaty would be highly beneficial to Iraq for multiple reasons. First of all, it would create a strong legal guarantee for foreign investors seeking to invest in the area. In lieu of proper domestic law, the various articles that were discussed in Chapter 4 and Chapter 5 could provide the necessary legal framework that foreign investors would feel comfortable with. And to be specific, the Energy Charter Treaty explicitly deals with the issue of expropriation, and thus its adoption would patch up a significant legal abscess in Iraqi law, and in a manner that is not only satisfactory, but also attractive to foreign investors (as mentioned in the dissertation before, foreign investors typically consider international treaties more potent and secure than domestic laws, especially when it comes to developing countries). 
And when it comes to the Kurdistan Region, the adoption of the Energy Charter Treaty would not only alleviate the inadequacies of the region's Law on Investment (that was discussed in Chapter 6), especially in regards to expropriation, it would also solve the issue of transit. As discussed at great length in Chapter 5, the Energy Charter Treaty provides provisions for transit disputes and issues. If Iraq, and by extension, the Kurdistan Region, becomes a contracting party of the Energy Charter Treaty, it would be able to use these transit provisions to protect itself against any potential problems caused by Turkey (which, as mentioned in the introduction, is a contracting party of the Energy Charter Treaty). Not only Turkey would be forced to respect the various principles of transit that were discussed in Chapter 5, it would also provide the Kurdistan Region with access to an effective and secure method of transit dispute resolution that Turkey would have to acquiesce to as a contracting party of the Energy Charter Treaty.

Thus, it can be stated without uncertainty that for Iraq, and the Kurdistan Region in specific, the Energy Charter Treaty would be a significant boon. It would not only boost the progress of economic development through attracting foreign investors, it would also lead to a more cohesive and secure relationship with nearby transit countries (Turkey, to be specific) that are contracting parties of the Energy Charter Treaty.

To conclude the work, I believe that further integration in the field of energy law is imminent and inevitable. As the global economic relations strengthen, more and more integration and cooperation will be required to feed the ever-growing energy demands of the globe. The Energy Charter Treaty can be considered an early forerunner of these intentions, and the legacy of which will be continued by such documents and events as the Road Map for the Modernization of the Energy Charter Process or the International Energy Charter. These remain reliant on the Energy Charter Treaty, and cannot be considered its true successors, but they represent the future that is to come. Further research on the subject should prove bountiful in a decade or so, as the speed of the integration greatly fluctuates. 


\section{Bibliography}

\section{Books and Articles}

1. AAKEN, Anne van, "Control Mechanisms in International Investment Law' (2013)

2. ABLIA, Ben, Les aspects actuels des problèmes d'indemnisation en droit international (DPhil dissertation, Université Paris I, 1980)

3. ALLEN, Tom, The Right to Property in Commonwealth Constitutions (Cambridge University Press, 2000)

4. AKINSANYA, Adeoye A., The Expropriation of Multinational Property in the Third World (Praeger, 1980)

5. AMERASINGHE, C. F., 'Issues of Compensation in the Taking of Property in the Light of Recent Cases and Practice' (1992) 41 ICLO

6. BĚLOHLÁVEK, Alexander J., Filip Černý, Naděžda Rozehnalova, Czech Yearbook of International Law - The Role of Governmental and Non-governmental Organizations in the 21st Century - 2014 (Juris Publishing, Inc., 2014)

7. BELYI, Andrei V., A Russian Perspective on the Energy Charter Treaty (Real Instituto Eleano, 2009)

8. BERNASCONI-Osterwalder, Nathalie, Rhea Tamara Hoffmann. 'The German nuclear phase-out put to the test in international investment arbitration? Background to the new dispute Vattenfall v. Germany (II)' (International Institute for Sustainable Development, 2012)

9. BERNASCONI-Osterwalder, Nathalie, Rhea Tamara Hoffmann 'The Change in Transnational Labour and Economic Law' (Georgetown University Law School, 2013)

10. BOBO, Benjamin F., Rich Country and Poor Country; The Multinational as Change Agent (Greenwood Publishing Group, 2005)

11. BOCZEK, Boleslaw Adam, International Law: A Dictionary (Scarecrow Press, 2005)

12. BROOKS, Petya Koeva, 'Time-to-Build and Convex Adjustment Costs' (2001) International Monetary Fund 
13. BROWN, Chester, Commentaries on Selected Model Investment Treaties (OUP Oxford, 2013)

14. CAMERON, Peter D, 'Stability of Contract in the International Energy Industry' (2009) 27, no. 3 Journal of Energy \& Natural Resources Law

15. CHEN, Deming, Economic Crisis and Rule Reconstruction (World Scientific, 2016)

16. CHOI, Young Back, Perspectives on Korean Unification and Economic Integration (Edward Elgar Publishing, 2001)

17. CHOUKROUNE, Leïla, Judging the state in International Trade and Investment Law: Sovereignty Modern, the Law and the Economics; International Law and the Global South (Springer, 2016)

18. COOP, Graham, Energy Dispute Resolution: Investment Protection, Transit and the Energy Charter Treaty (Juris Publishing, Inc., 2011)

19. COSBEY, Aaron, Jennifer Ellis, Mahnaz Malik and Howard Mann, 'Clean energy investment: project syndissertation report' (International Institute for Sustainable Development, Winnipeg, 2008)

20. COTULA, Lorenzo, 'Regulatory takings, stabilization clauses and sustainable development' (2008) OECD Investment Policy Perspectives

21. CRAWFORD, James, R. Doak Bishop, William Michael Reisman, , Foreign Investment Disputes: Cases, Materials, and Commentary (Kluwer Law International, 2005)

22. DEMIRKOL, Berk, 'The Notion of 'Investment' in International Investment Law' (2015) 41 Turkish Commercial Law Review

23. DIAS, Simoes Fernando, 'When Green Incentives Go Pale: Investment Arbitration and Renewable Energy Policymaking' (2016) Denv. J. Int'1 L. \& Pol'y 45

24. DIMOPOULOS, Angelos, EU Foreign Investment Law (Oxford University Press Oxford, 2011)

25. DOLZER, Rudolf, Christoph Schreuer, Principles of international investment law (Oxford University Press, 2012)

26. ERKAN, Mustafa, International Energy Investment Law: Stability Through Contractual Clauses (Kluwer Law International, 2011) 
27. FAUCHALD, Ole Kristian, Behn Daniel, 'Governments under Cross-Fire: Renewable Energy and International Economic Tribunals' (2015) Manchester J. Int'1 Econ. L. 12

28. GLINAVOS, Ioannis, 'Solar eclipse: investment treaty arbitration and Spain's photovoltaic troubles' in Lessons from the great recession: At the crossroads of sustainability and recovery (Emerald Group Publishing Limited, 2016)

29. GUZMAN, A., 'Why LDCs Sign Treaties That Hurt Them: Explaining the Popularity of Bilateral Investment Treaties' (1998) 38 Virginia Journal of International Law

30. GWYNN, Maria A., Power in the International Investment Framework (Springer, 2016)

31. HAGHIGHI, Sanam S., Energy Security: The External Legal Relations of the European Union with Major Oil and Gas Supplying Countries (Bloomsbury Publishing, 2007)

32. HODGSON, Matthew, Alastair Campbell, 'Damages and costs in investment treaty arbitration revisited' (Global Arbitration Review, 2017)

33. JACUR, F., 'The Vattenfall v. Germany Disputes: Finding a Balance Between Energy Investments and Public Concerns'

34. JONES, Vivian Catherine, Akhtar Shayerah Ilias, 'Proposed Transatlantic Trade and Investment Partnership (T-TIP): In Brief' (2014) Volume 24, Number 1/2. Current Politics and Economics of Europe

35. JUSOH S, J Chaisse, The ASEAN Comprehensive Investment Agreement (Edward Elgar Pub-lishing 2016)

36. KATZAROV, Konstantin, The Theory of Nationalisation (Springer Science \& Business Media, 2012)

37. KHAPOYA, Vincent B, The African Experience (Routledge, 2015)

38. KRAJEWSKI, Markus, 'The impact of international investment agreements on energy regulation' in European Yearbook of International Economic Law 2012 (Springer Berlin Heidelberg, 2012)

39. KOSKENNIEMI, Martti, International Law Aspects of the European Union (Martinus Nijhoff Publishers, 1998) 
40. LAUTERPACHT, Elihu, James Crawford \& Karen Lee, Reports of Cases Decided Under the Convention on the Settlement of Investment Disputes Between states and Nationals of Other states 1965, Thirteen version of ICSID Reports (Cambridge University Press, 2008)

41. LEISEROWITZ, Anthony A, Kates Robert W, Thomas M Parris, 'What is sustainable development?' (2005) Environment 47, no. 3

42. LUCCA, Anna de, 'Renewable energy in the EU, the Energy Charter Treaty, and Italy's Withdrawal Therefrom'

43. MALIK, M., 'Recent Developments in the Definition of Investment in International Investment Agreements, International Institute for Sustainable Development' (2008)

44. MALINTOPPI, Loretta, Charis Tan, Investment Protection in Southeast Asia: A Country-by-Country Guide on Arbitration Laws and Bilateral Investment Treaties (BRILL, 2016)

45. MAPP, Wayne, The Iran-United states Claims Tribunal: The First Ten Years, 19811991: an Assessment of the Tribunal's Jurisprudence and Its Contribution to International Arbitration (Manchester University Press, 1993)

46. MONTT, Santiago, State Liability in Investment Treaty Arbitration: Global Constitutional and Administrative Law in the BIT Generation Studies in International Law (Bloomsbury Publishing, 2009)

47. NAGY, Csongor István, 'Free Trade, Public Interest and Reality: New Generation Free Trade Agreements and National Regulatory Sovereignty' (2018) vol. IX Czech Yearbook of International Law

48. NATHANSON, Rachel An, 'The revocation of clean-energy investment economic-support systems as indirect expropriation post-nykomb: A Spanish case analysis' (2012) 98 IOWA LAW REVIEW

49. NEWCOMBE, A., L. Paradell, Law and Practice of Investment Treaties: Standards of Treatment (2009)

50. NG'AMBI, Sangwani Patrick, Resource Nationalism in International Investment Law (Routledge, 2015)

51. NIKIÈMA, S.H, 'Compensation For Expropriation' 
52. MICARA, Anna G., Angela Lupone, José Caiado, International Economic Law: Contemporary Issues (Springer, 2016)

53. O'CONNELL, D. P., The Law of state Succession (Cambridge University Press, 2015)

54. PAGACH, Donald, James M. Wahlen, Jefferson P. Jones, Intermediate Accounting: Reporting and Analysis (Cengage Learning, 2015)

55. PEDRAZA, Jorge Morales, Electrical Energy Generation in Europe: The Current and Future Role of Conventional Energy Sources in the Regional Generation of Electricity (Springer, 2014)

56. POLLAN, Thomas, Legal Framework for the Admission of FDI (Eleven International Publishing, 2006)

57. POMINOVA, Irina, Risks and Benefits for the Russian Federation from Participating in the Energy Charter: Comprehensive Analysis (Energy Charter Secretariat Knowledge Centre, 2014)

58. REETZ, C. Ryan, Pedro J. Martinez-Fraga, Public Purpose in International Law (Cambridge University Press, 2015)

59. RIPINSKY, Sergey, Kevin Williams, Damages in International Investment Law (BIICL, 2008)

60. SABAHI, Borzu, Compensation and Restitution in Investor-state Arbitration: Principles and Practice (International Economic Law Series, Oxford University Press Oxford, 2011)

61. SALACUSE, Jeswald W., The Law of Investment Treaties (Oxford University Press, 2015)

62. SCHEFER, Krista Nadakavukaren, International Investment Law: Text, Cases and Materials (2nd edn, Edward Elgar Publishing, 2016)

63. SCHREUER, Christoph, The concept of Expropriation under the Energy Charter Treaty and other Investment Protection Treaties

64. SCHREUER, Christoph, The Relevance of Public International Law in International Commercial Arbitration: Investment Disputes

65. SCHILL, Stephan W., Epaminontas E. Triantafilou, Abby Cohen Smutny, Practising Virtue: Inside International Arbitration (Oxford University Press, 2015) 
66. SCHILL, Stephan, Do Investment Treaties Chill Unilateral State Regulation to Mitigate Climate Change? (2007) 24(5) Journal of International Arbitration

67. SCHILL, Stephan W., The Multilateralization of International Investment Law (Cambridge University Press, 2009)

68. SCHWEBEL, Stephen M., 'The story of the UNs Declaration on Permanent Sovereignty over National Resources' (1963) 49 American Bar Association Journal

69. SEBASTIAN, Sampallo, 'Investor-state dispute settlement in the TTIP-A fair dispute resolution mechanism or the bane of democracy?' (2016)

70. SELIVANOVA, Julia, Regulation of Energy in International Trade Law: WTO, NAFTA, and Energy Charter (Kluwer Law International, 2011)

71. SHIHATA, Ibrahim F. I., Legal Treatment of Foreign Investment: "The World Bank Guidelines" International Studies in Human Rights (Martinus Nijhoff Publishers, 1993)

72. SIEKMEIER, James F., The Bolivian Revolution and the United states from 1952 to the Present (Penn State Press, 2011)

73. SINHA, Tapen, Bradly J. Condon, The role of climate change in global economic governance (Oxford University Press, 2013)

74. SORNARAJAH, M., The International Law on Foreign Investment (Cambridge University Press, 2010)

75. SULEIMANOV, Maidan, Ilias Bantekas, John Paterson, Oil and Gas Law in Kazakhstan: National and International Perspectives ( Kluwer Law International, 2004)

76. SUPACHAI, Panitchpakdi, Expropriation: A Sequel (UNCTAD, 2012)

77. STRATMAN, Klaus, 'Vattenfall verklagt Deutschland'

78. TIMOFEYEV, Igor, Charles Patrizia, Joseph Profaizer, 'GAR Chapter: Investment Disputes Involving The Renewable Energy Industry Under The Energy Charter Treaty'

79. TIETJE, Christian, International Investment, Protection and Arbitration: Theoretical and Practical Perspectives (BWV Verlag, 2011) 
80. TOMANEK, Pavel, 'Italy And Spain Hit By More Solar Energy Cases | Global Investment Protection'

81. TSAGAO, Traore-, 'La garantie des investissements étrangers en Afrique et droit international' (DPhil dissertation, A.N.R.T, Université de Lille III, 2001)

82. TURK, Rima, Nikièma, Financial Decisions and Investment Outcomes in Developing Countries: The Role of Institutions (International Monetary Fund, 2015)

83. VESQUE, C Line L, Armand L. C. De Mestral, Improving International Investment Agreements Routledge research in international economic law (Routledge, 2013)

84. VÍG, Zoltan, Requirements of lawful taking of foreign property in international law (Iurisperitus Kiado, Szeged, 2016)

85. VIÑUALES, Jorge E., Foreign investment and the environment in international law Vol. 94. (Cambridge University Press, 2012)

86. WAELDE, Thomas, Craig Bamberger, Jan Linehan, The Energy Charter Treaty in 2000: In a New Phase (Oxford University Press, 2000)

87. WANG, Henry K. H., Energy Markets in Emerging Economies: Strategies for growth, (Routledge, 2016)

88. WALLACE, Richard L. et al., The Marine Mammal Commission compendium of selected treaties, international agreements, and other relevant documents on marine resources, wildlife, and the environment (Washington, D.C., The Commission, 1999)

89. WERKSMAN Jacob et al., 'Will International Investment Rules Obstruct Climate Protection Policies? An Examination of the Clean Development Mechanism' (2003) 3 International Environmental Agreements: Politics, Law and Economics

90. WOODIE, Francis, Nationalisation, indemnisation et développement, colloque international d'Alger (1976)

91. WOODWARD, Douglas P., Douglas William Nigh, Foreign Ownership and the Consequences of Direct Investment in the United states: Beyond Us and Them (Greenwood Publishing Group, 1998) 
92. YANNACA-Small Katia, Arbitration Under International Investment Agreements: A Guide to the Key Issues (Oxford University Press, 2010)

1. Alternative Dispute Resolution In The Energy Sector (Maklu 2009)

2. 'Declaration of Human and Civic Rights' (Conseil-constitutionnel.fr, 1789)

3. Energy Department, Annual Energy Review 2008 (Government Printing Office, 2009)

4. IBP, Inc, Iraq Country Study Guide Volume 1 Strategic Information and Developments World Business Information Catalog (International Business Publications, Inc. 2012)

5. IBP, Inc, Russia Energy Policy laws and Regulations Handbook, vol 1 (World Business and Investment Library, 2015)

6. Memo from Belgium (University of Pennsylvania, 2009)

7. OECD Investment Policy Perspectives 2008 (OECD Publishing, 2009)

8. Office of Energy Markets and End Use, Short term energy outlook: Quarterly projections (The Office, 1995)

9. $\quad$ Taking Of Property (United Nations 2000)

10. Yearbook of the International Law Commission 2000 (United Nations Publications, 2010)

\section{Treaties}

1. Vienna Convention on the law of treaties (with annex). Concluded at Vienna on 23 May 1969

2. Bilateral Investment Agreements between Algeria and China

3. Energy Charter Treaty 


\section{Appendix: Table of Cases}

\begin{tabular}{|c|c|c|c|c|c|}
\hline Cases & $\begin{array}{l}\text { CLAIMAN- } \\
\text { T'S ARGU- } \\
\text { MENTS }\end{array}$ & $\begin{array}{l}\text { RESPON- } \\
\text { DENT'S } \\
\text { ARGU- } \\
\text { MENTS }\end{array}$ & AWARD & & $\begin{array}{c}\text { Paragraph of } \\
\text { Energy } \\
\text { Charter } \\
\text { Treaty }\end{array}$ \\
\hline $\begin{array}{l}\text { Nykomb } \\
\text { Synergies } \\
\text { Technology } \\
\text { Holding AB } \\
\text { v Republic } \\
\text { of Latvia, } \\
\text { IIC 182 } \\
(2003)\end{array}$ & $\begin{array}{l}\text { Breached } \\
\text { Article 10(1) } \\
\underline{\text { and } 13(1)}\end{array}$ & $\begin{array}{l}\text { Denied } \\
\text { breaching } \\
\text { Energy } \\
\text { Charter } \\
\text { Treaty. } \\
\text { Acts of Par- } \\
\text { liament can- } \\
\text { not be con- } \\
\text { strued to be } \\
\text { acts by } \\
\text { Latvenergo }\end{array}$ & $\begin{array}{l}\text { Breached } \\
\text { Article 10(1) } \\
\text { and } 13(1)\end{array}$ & $\begin{array}{l}\text { Claimants } \\
\text { won }\end{array}$ & $\begin{array}{l}\text { PART III } \\
\text { INVEST- } \\
\text { MENT } \\
\text { PROMO- } \\
\text { TION AND } \\
\text { PROTEC- } \\
\text { TION } \\
\text { and } \\
\text { ARTICLE } \\
13 \\
\text { EXPRO- } \\
\text { PRIATION }\end{array}$ \\
\hline $\begin{array}{l}\text { Petrobart } \\
\text { Limited v } \\
\text { The Kyrgyz } \\
\text { Republic, } \\
\text { SCC Case } \\
\text { N o } \\
126 / 2003\end{array}$ & $\begin{array}{l}\text { Breached } \\
\text { Article } \\
\frac{10(1), 10(12),}{13(1), 22(1)}\end{array}$ & $\begin{array}{l}\text { Denied } \\
\text { breaching } \\
\text { Energy } \\
\text { Charter } \\
\text { Treaty. } \\
\text { No invest- } \\
\text { ment in the } \\
\text { country, }\end{array}$ & $\begin{array}{l}\text { Breached } \\
\text { Article10(1), } \\
\text { violated } \underline{\mathrm{Ar}}- \\
\underline{\text { ticle } 13(1)}\end{array}$ & $\begin{array}{l}\text { Claimants } \\
\text { won }\end{array}$ & $\begin{array}{l}\text { PART III } \\
\text { INVEST- } \\
\text { MENT } \\
\text { PROMO- } \\
\text { TION AND } \\
\text { PROTEC- } \\
\text { TION } \\
\text { and } \\
\text { ARTICLE } \\
13 \\
\text { EXPRO- } \\
\text { PRIATION }\end{array}$ \\
\hline $\begin{array}{l}\text { IOANNIS } \\
\text { KARDAS- } \\
\text { SOPOU- } \\
\text { LOS V THE } \\
\text { REPUBLIC } \\
\text { OF GEOR- } \\
\text { GIA }\end{array}$ & $\begin{array}{l}\text { Breached of } \\
\text { Article 13(1) }\end{array}$ & $\begin{array}{l}\text { Arbitration } \\
\text { tribunal did } \\
\text { not have } \\
\text { jurisdic- } \\
\text { tion. Time } \\
\text { barred as the } \\
\text { delay was } \\
\text { reasonable }\end{array}$ & $\begin{array}{l}\text { Breached } \\
\text { their obliga- } \\
\text { tions to pro- } \\
\text { vide in- } \\
\text { vestors with } \\
\text { fair and eq- } \\
\text { uitable } \\
\text { treatment in } \\
\text { article } 13 \text { of } \\
\text { Energy } \\
\text { Charter } \\
\text { Treaty }\end{array}$ & $\begin{array}{l}\text { Claimants } \\
\text { won }\end{array}$ & $\begin{array}{l}\text { Article } 13 \\
\text { EXPRO- } \\
\text { PRIATION }\end{array}$ \\
\hline
\end{tabular}




\begin{tabular}{|c|c|c|c|c|c|}
\hline $\begin{array}{l}\text { LIMITED } \\
\text { LIABILITY } \\
\text { COMPANY } \\
\text { A M T O v } \\
\text { UKRAINE }\end{array}$ & $\begin{array}{l}\mathrm{Breached} \\
\operatorname{art~} \mathrm{ic} \mathrm{e} \mathrm{s} \\
10(1) \\
10(12), \text { and } \\
22(1)\end{array}$ & $\begin{array}{l}\text { Tribunal did } \\
\text { not h a v e } \\
\text { jurisdiction } \\
\text { under Article } \\
\text { (26) and did } \\
\text { not qualify } \\
\text { as an 'In- } \\
\text { vestment } \\
\text { under the } \\
\text { Article (6). }\end{array}$ & $\begin{array}{l}\text { Dismissed } \\
\text { the claims as } \\
\text { the Claimant } \\
\text { did have an } \\
\text { 'Investment' } \\
\text { within the } \\
\text { meaning of } \\
\text { the Energy } \\
\mathrm{C} \text { h a } \mathrm{rter} \\
\text { Treaty }\end{array}$ & $\begin{array}{l}\text { Claimant } \\
\text { lost }\end{array}$ & $\begin{array}{l}\text { PART III } \\
\text { INVEST- } \\
\text { MENT } \\
\text { PROMO- } \\
\text { TION AND } \\
\text { PROTEC- } \\
\text { TION }\end{array}$ \\
\hline $\begin{array}{l}\text { EUR O P E } \\
\text { CEMEN T } \\
\text { IN V ES T- } \\
\text { MENT \& } \\
\text { TRADE V } \\
\text { REPUBLIC } \\
\text { OF T UR- } \\
\text { KEY }\end{array}$ & $\begin{array}{l}\text { Breached } \\
\text { article } 13, \\
\text { and } 10(1)\end{array}$ & $\begin{array}{l}\text { Tribunal had } \\
\text { no jurisdic- } \\
\text { tion. }\end{array}$ & $\begin{array}{l}\text { It did not } \\
\text { have juris- } \\
\text { diction to } \\
\text { hear the case }\end{array}$ & $\begin{array}{l}\text { Claimant } \\
\text { lost }\end{array}$ & $\begin{array}{l}\text { PART III } \\
\text { INVEST- } \\
\text { MENT } \\
\text { PROMO- } \\
\text { TION AND } \\
\text { PROTEC- } \\
\text { TION and } \\
\text { ARTICLE } \\
\text { 13 EXPRO- } \\
\text { PRIATION }\end{array}$ \\
\hline $\begin{array}{l}\text { P L A M A } \\
\text { CONSOR- } \\
\text { TIUM LIM- } \\
\text { I T E D V } \\
\text { REPUBLIC } \\
\text { OF B U L- } \\
\text { GARIA }\end{array}$ & $\begin{array}{l}\text { Violated } \\
\text { Article 10(2) }\end{array}$ & $\begin{array}{l}\text { Denied } \\
\text { breaching } \\
\text { Energy } \\
\text { Charter } \\
\text { Treaty. } \\
\text { Claimant } \\
\text { breached } \\
\underline{\text { Article }} \\
\underline{17(1)} .\end{array}$ & $\begin{array}{l}\text { Refused that } \\
\text { claimant } \\
\text { breached } \\
\text { Article 17(1) } \\
\text { also rejected } \\
\text { that respon- } \\
\text { dent } \\
\text { breached } \\
\text { Article 10(2) }\end{array}$ & $\begin{array}{l}\text { Claimant } \\
\text { lost }\end{array}$ & $\begin{array}{l}\text { PART III } \\
\text { INVEST- } \\
\text { MENT } \\
\text { PROMO- } \\
\text { TION AND } \\
\text { PROTEC- } \\
\text { TION and } \\
\text { ARTICLE } \\
17 \\
\text { NON-AP- } \\
\text { PLICATION } \\
\text { OF PART III } \\
\text { IN CER- } \\
\text { TAIN CIR- } \\
\text { CUM- } \\
\text { STANCES }\end{array}$ \\
\hline $\begin{array}{l}\text { AZPETRO } \\
\text { L v AZER- } \\
\text { BAIJAN }\end{array}$ & $\begin{array}{l}\text { violation of } \\
\text { Articles } 13, \\
10,14 \text { and } \\
22\end{array}$ & $\begin{array}{l}\text { NO need for } \\
\text { arbitration } \\
\text { by the ICSID } \\
\text { as the case } \\
\text { was settled }\end{array}$ & $\begin{array}{l}\text { the case was } \\
\text { dismissed as } \\
\text { there was no } \\
\text { 'legal dis- } \\
\text { pute' as re- } \\
\text { quired by } \\
\text { Energy } \\
\text { Charter } \\
\text { Treaty }\end{array}$ & $\begin{array}{l}\text { Claimant } \\
\text { lost }\end{array}$ & \\
\hline
\end{tabular}




\begin{tabular}{|c|c|c|c|c|c|}
\hline $\begin{array}{l}\text { C E M E N- } \\
\text { TOWNIA } \\
\text { S.A v Re- } \\
\text { public of } \\
\text { Turkey }\end{array}$ & $\begin{array}{l}\text { Viol a ted } \\
\text { A r t c l e s } \\
10(1), 13\end{array}$ & $\begin{array}{l}\text { Rejected the } \\
\text { jurisdiction } \\
\text { of the IC- } \\
\text { SID. }\end{array}$ & $\begin{array}{l}\text { case was } \\
\text { dismissed as } \\
\text { Claimant } \\
\text { was trying to } \\
\text { transfer as- } \\
\text { sets to gain } \\
\text { jurisdiction } \\
\text { to the Ener- } \\
\text { gy Charter } \\
\text { Treaty }\end{array}$ & $\begin{array}{l}\text { Claimant } \\
\text { lost }\end{array}$ & $\begin{array}{l}\text { PART III } \\
\text { INVEST- } \\
\text { MENT } \\
\text { PROMO- } \\
\text { TION AND } \\
\text { PROTEC- } \\
\text { TION and } \\
\text { ARTICLE } \\
\text { 13 EXPRO- } \\
\text { PRIATION }\end{array}$ \\
\hline $\begin{array}{l}\text { MOH A M- } \\
\text { M A D } \\
\text { A M M A R } \\
\text { A L - } \\
\text { BAHLOUL } \\
\text { V REPUB- } \\
\text { L I C O F } \\
\text { T A J I K- } \\
\text { ISTAN }\end{array}$ & $\begin{array}{l}\text { B reached } \\
\text { A r t i c le } \\
10(1), \quad(7), \\
\text { and Article } \\
13 .\end{array}$ & $\begin{array}{l}\text { Denied } \\
\text { breaching } \\
\text { Energy } \\
\text { Charter } \\
\text { Treaty. }\end{array}$ & $\begin{array}{l}\text { breached its } \\
\text { obligations } \\
\text { under Article } \\
\text { 10(1). Other } \\
\text { claims were } \\
\text { denied }\end{array}$ & $\begin{array}{l}\text { Claimant } \\
\text { won }\end{array}$ & $\begin{array}{l}\text { PART III } \\
\text { INVEST- } \\
\text { MENT } \\
\text { PROMO- } \\
\text { TION AND } \\
\text { PROTEC- } \\
\text { TION }\end{array}$ \\
\hline $\begin{array}{l}\text { L I M A N } \\
\text { C A S P E R } \\
\text { OIL BV and } \\
\mathrm{N} \text { C L } \\
\text { D U T C H } \\
\text { IN V E S T- } \\
\text { M E N T V } \\
\text { REPUBLIC } \\
\text { O } \\
\text { K H A Z K- } \\
\text { STAN }\end{array}$ & $\begin{array}{l}\text { violated Ar- } \\
\text { ticle 13(1), } \\
10(1)\end{array}$ & $\begin{array}{l}\text { Tribunal had } \\
\text { no jurisdic- } \\
\text { tion.claimed } \\
\text { that under } \\
\text { Article 17(1) } \\
\text { it had the } \\
\text { right to deny } \\
\text { advantages } \\
\text { given to for- } \\
\text { eign in- } \\
\text { vestors if } \\
\text { they breach } \\
\text { their obliga- } \\
\text { tions under } \\
\text { the Energy } \\
\text { Charter } \\
\text { Treaty. }\end{array}$ & $\begin{array}{l}\text { It did have } \\
\text { jurisdiction } \\
\text { to hear the } \\
\text { case as both } \\
\text { sides had } \\
\text { prima facie } \\
\text { claims to be } \\
\text { tried. } \\
\text { the Tribunal } \\
\text { considered } \\
\text { the costs. It } \\
\text { decided that } \\
\text { since the } \\
\text { Claimant } \\
\text { had won the } \\
\text { jurisdictional } \\
\text { phase of the } \\
\text { case, and the } \\
\text { Respondent } \\
\text { won the mer- } \\
\text { its part of the } \\
\text { case, that } \\
\text { both parties } \\
\text { could share } \\
\text { the cost } \\
\text { equally, }\end{array}$ & $\begin{array}{l}\text { Claimants } \\
\text { and Re- } \\
\text { spondent } \\
\text { won }\end{array}$ & $\begin{array}{l}\text { PART III } \\
\text { INVEST- } \\
\text { MENT } \\
\text { PROMO- } \\
\text { TION AND } \\
\text { PROTEC- } \\
\text { TION and } \\
\text { ARTICLE } \\
\text { 13 EXPRO- } \\
\text { PRIATION }\end{array}$ \\
\hline
\end{tabular}




\begin{tabular}{|c|c|c|c|c|c|}
\hline $\begin{array}{l}\text { VAT TEN- } \\
\text { FALL AB } \\
\text { A N D D } \\
\text { OTHERS v. } \\
\text { FEDERAL } \\
\text { REPUBLIC } \\
\text { OF GE R- } \\
\text { MANY }\end{array}$ & $\begin{array}{l}\text { Breached } \\
\text { articles } 10 \\
\text { and } 13 \text { of the } \\
\text { Energy } \\
\text { Charter } \\
\text { Treaty }\end{array}$ & $\begin{array}{l}\text { denied the } \\
\text { breach }\end{array}$ & $\begin{array}{l}\text { the parties } \\
\text { under Article } \\
3 \text { agree to } \\
\text { suspend pro- } \\
\text { ceedings } \\
\text { indefinitely } \\
\text { and neither } \\
\text { Parties may } \\
\text { resume pro- } \\
\text { ceedings } \\
\text { unilaterally } \\
\text { except by } \\
\text { Article 4 } \\
\text { through joint } \\
\text { application. } \\
\text { The parties } \\
\text { admit no } \\
\text { admission or } \\
\text { acknowl- } \\
\text { edgment of } \\
\text { any liability } \\
\text { or wrongdo- } \\
\text { ing whatso- } \\
\text { ever. }\end{array}$ & $\begin{array}{l}\text { No award } \\
\text { was given }\end{array}$ & $\begin{array}{l}\text { PART III } \\
\text { INVEST- } \\
\text { MENT } \\
\text { PROMO- } \\
\text { TION AND } \\
\text { PROTEC- } \\
\text { TION and } \\
\text { ARTICLE } \\
13 \text { EXPRO- } \\
\text { PRIATION }\end{array}$ \\
\hline $\begin{array}{l}\text { AES } \\
\text { SUMMIT G } \\
\text { ENERA- } \\
\text { TION LIM- } \\
\text { ITED AND } \\
\text { AES-TISZA } \\
\text { ERÖMÜ } \\
\text { KFT. V. HU } \\
\text { NGARY }\end{array}$ & $\begin{array}{l}\text { Breached } \\
\text { Article } \\
10(1), 10(7), \\
\text { and } 13\end{array}$ & $\begin{array}{l}\mathrm{H} \mathrm{ung} \text { a ry } \\
\text { joining the } \\
\text { E U, the } \\
\text { C laimant } \\
\text { should have } \\
\text { expected that } \\
\text { there would } \\
\text { be changes } \\
\text { in laws that } \\
\text { would affect } \\
\text { the PPA. }\end{array}$ & $\begin{array}{l}\text { claim was } \\
\text { dismissed }\end{array}$ & $\begin{array}{l}\text { Claimant } \\
\text { lost }\end{array}$ & $\begin{array}{l}\text { PART III } \\
\text { INVEST- } \\
\text { MENT } \\
\text { PROMO- } \\
\text { TION AND } \\
\text { PROTEC- } \\
\text { TION and } \\
\text { ARTICLE } \\
13 \text { EXPRO- } \\
\text { PRIATION }\end{array}$ \\
\hline $\begin{array}{l}\text { KHAN RE- } \\
\text { SOURCES } \\
\text { I C C V } \\
\text { G O V- } \\
\text { ERNMENT } \\
\text { OF MON- } \\
\text { GOLIA }\end{array}$ & $\begin{array}{l}\text { Breached } \\
\text { Article 10(1) } \\
\underline{\text { and 13(1) }}\end{array}$ & $\begin{array}{l}\text { Denied the } \\
\text { breach of } \\
\text { Energy } \\
\text { Charter } \\
\text { Treaty. } \\
\text { Claimant } \\
\text { had } \\
\text { repeatedly } \\
\text { breached } \\
\text { Mongolian } \\
\text { law }\end{array}$ & $\begin{array}{l}\text { Respondents } \\
\text { had breached } \\
\text { their } \\
\text { obligations } \\
\text { towards the } \\
\text { Claimants } \\
\text { under Article } \\
\text { 10(1) of the } \\
\text { Energy } \\
\text { Charter } \\
\text { Treaty }\end{array}$ & $\begin{array}{l}\text { Claimant } \\
\text { won }\end{array}$ & $\begin{array}{l}\text { Unreason- } \\
\text { able and } \\
\text { discrimina- } \\
\text { tory mea- } \\
\text { sures.expro- } \\
\text { priation of } \\
\text { investment } \\
\text { without } \\
\text { compensa- } \\
\text { tion }\end{array}$ \\
\hline
\end{tabular}




\begin{tabular}{|c|c|c|c|c|c|}
\hline $\begin{array}{l}\text { LIBANAN } \\
\text { CO HOLD- } \\
\text { INGS CO. } \\
\text { LIMITED v } \\
\text { REPUBLIC } \\
\text { OF TUR- } \\
\text { KEY }\end{array}$ & $\begin{array}{l}\text { violated Ar- } \\
\text { ticle } 13 \\
10(1)\end{array}$ & $\begin{array}{l}\text { Claimant has } \\
\text { no jurisdic- } \\
\text { tion. There } \\
\text { was no "In- } \\
\text { vestor" or } \\
\text { "Investment" } \\
\text { Energy } \\
\text { Charter } \\
\text { Treaty can- } \\
\text { not be relied } \\
\text { upon be- } \\
\text { cause it did } \\
\text { not enter } \\
\text { force into } \\
\text { Turkey until } \\
\text { after the } \\
\text { actions }\end{array}$ & $\begin{array}{l}\text { Claimant } \\
\text { had failed } \\
\text { prove that it } \\
\text { owned the } \\
\text { investment, } \\
\text { at the time of } \\
\text { the alleged } \\
\text { expropria- } \\
\text { tion. } \\
\text { Claimant } \\
\text { could not } \\
\text { benefit from } \\
\text { Article 17(1) } \\
\text { regarding } \\
\text { denial of } \\
\text { benefits. }\end{array}$ & $\begin{array}{l}\text { Claimant } \\
\text { lost }\end{array}$ & $\begin{array}{l}\text { PART III } \\
\text { INVEST- } \\
\text { MENT } \\
\text { PROMO- } \\
\text { TION AND } \\
\text { PROTEC- } \\
\text { TION } \\
\text { and } \\
\text { ARTICLE } \\
13 \\
\text { EXPRO- } \\
\text { PRIATION }\end{array}$ \\
\hline $\begin{array}{l}\text { ENER- } \\
\text { GOAL- } \\
\text { LIANCE } \\
\text { LTD. V } \\
\text { REPUBLIC } \\
\text { OF } \\
\text { MOLDOVA }\end{array}$ & $\begin{array}{l}\text { Breached } \\
\text { Article } \\
10(1), \text { Arti- } \\
\text { cle } 10(12) \\
\text { and Article } \\
13(1)\end{array}$ & $\begin{array}{l}\text { The Respon- } \\
\text { dent denied } \\
\text { all of the } \\
\text { allegations } \\
\text { that it } \\
\text { breached } \\
\text { Articles } \\
10(1), \\
10(12) \text {, or } \\
\text { 13(1) of the } \\
\text { Energy } \\
\text { Charter } \\
\text { Treaty }\end{array}$ & $\begin{array}{l}\text { The Tribunal } \\
\text { awarded } \\
\text { judgment in } \\
\text { favour of the } \\
\text { Claimants } \\
\text { with dis- } \\
\text { missed the } \\
\text { claims that } \\
\text { there was a } \\
\text { denial of } \\
\text { justice under } \\
\text { Article } \\
10(12)\end{array}$ & $\begin{array}{l}\text { Claimant } \\
\text { won }\end{array}$ & $\begin{array}{l}\text { PART III } \\
\text { INVEST- } \\
\text { MENT } \\
\text { PROMO- } \\
\text { TION AND } \\
\text { PROTEC- } \\
\text { TION } \\
\text { and } \\
\text { ARTICLE } \\
13 \\
\text { EXPRO- } \\
\text { PRIATION }\end{array}$ \\
\hline $\begin{array}{l}\text { ASCOM } \\
\text { AND STA- } \\
\text { TI v } \\
\text { KHAZA- } \\
\text { KHSTAN }\end{array}$ & $\begin{array}{l}\text { Breached } \\
\text { Article } \\
\text { 10(1), Arti- } \\
\text { cle 13. }\end{array}$ & $\begin{array}{l}\text { Denied all of } \\
\text { the claims. }\end{array}$ & $\begin{array}{l}\text { The Tribunal } \\
\text { ruled in } \\
\text { favour of the } \\
\text { Claimant. }\end{array}$ & $\begin{array}{l}\text { Claimant } \\
\text { won }\end{array}$ & $\begin{array}{l}\text { PART III } \\
\text { INVEST- } \\
\text { MENT } \\
\text { PROMO- } \\
\text { TION AND } \\
\text { PROTEC- } \\
\text { TION } \\
\text { and } \\
\text { ARTICLE } \\
13 \\
\text { EXPRO- } \\
\text { PRIATION }\end{array}$ \\
\hline
\end{tabular}




\begin{tabular}{|c|c|c|c|c|c|}
\hline $\begin{array}{l}\text { Yukos Uni- } \\
\text { versal Ltd. } \\
\text { (UK Isle of } \\
\text { M a n ) v } \\
\text { R u s s i a n } \\
\text { Federation } \\
\text { U N C I- } \\
\text { TRAL, PCA } \\
\text { Case No. } \\
\text { AA227 }\end{array}$ & $\begin{array}{l}\text { Breached } \\
\text { Article 10(1) } \\
\underline{\text { and 13(1) }}\end{array}$ & $\begin{array}{l}\text { Denied } \\
\text { breaching } \\
\text { Energy } \\
\text { Charter } \\
\text { Treaty. } \\
\text { The enter- } \\
\text { prise had } \\
\text { used various } \\
\text { shell compa- } \\
\text { nies and } \\
\text { fronts in } \\
\text { order to } \\
\text { evade taxes }\end{array}$ & $\begin{array}{l}\text { Breached } \\
\text { Article 13(1) }\end{array}$ & $\begin{array}{l}\text { Claimants } \\
\text { won }\end{array}$ & $\begin{array}{l}\text { EXPRO- } \\
\text { PRIATION }\end{array}$ \\
\hline $\begin{array}{l}\text { H U L L E Y } \\
\text { E N T E R- } \\
\text { P R I S E S } \\
\text { LI M I T E D } \\
\text { V R U S S- } \\
\text { IAN FED- } \\
\text { ERATION }\end{array}$ & $\begin{array}{l}\text { The Respon- } \\
\text { dent } \\
\text { breached its } \\
\text { obligations } \\
\text { under Article } \\
10(1) \text { and } \\
13(1)\end{array}$ & $\begin{array}{l}\text { The claims } \\
\text { that the Tri- } \\
\text { bunal's scru- } \\
\text { tiny should } \\
\text { not be ap- } \\
\text { plied to its } \\
\text { taxation } \\
\text { measures } \\
\text { due to the } \\
\text { "carve-out } \\
\text { provision" } \\
\text { found in } \\
\text { Article 21(1) } \\
\text { of the Ener- } \\
\text { gy Charter } \\
\text { Treaty. }\end{array}$ & $\begin{array}{l}\text { The Respon- } \\
\text { dent } \\
\text { breached its } \\
\text { obligations } \\
\text { under Article } \\
\text { 13(1) of the } \\
\text { Energy } \\
\text { Charter } \\
\text { Treaty. } \\
\text { But The } \\
\text { Russian } \\
\text { Federation } \\
\text { claims the } \\
\text { tribunal's } \\
\text { decision was } \\
\text { politically } \\
\text { motivated, } \\
\text { and will seek } \\
\text { to set aside } \\
\text { the award, }\end{array}$ & $\begin{array}{l}\text { Claimant } \\
\text { won }\end{array}$ & $\begin{array}{l}\text { PART III } \\
\text { INVEST- } \\
\text { MENT } \\
\text { PROMO- } \\
\text { TION AND } \\
\text { PROTEC- } \\
\text { TION } \\
\text { and } \\
\text { ARTICLE } \\
13 \\
\text { EXPRO- } \\
\text { PRIATION }\end{array}$ \\
\hline $\begin{array}{l}\text { VETERAN } \\
\mathrm{P} \text { E- } \\
\text { TROLEUM } \\
\text { LIMITED } \mathrm{v} \\
\mathrm{R} \text { us s i a } \mathrm{n} \\
\text { Federation }\end{array}$ & $\begin{array}{l}\text { the Respon- } \\
\mathrm{d} \mathrm{e} \mathrm{n} \mathrm{t} \\
\text { breached its } \\
\text { obligations } \\
\text { under Article } \\
10(1) \text { and } \\
13(1) \text { of the } \\
\text { E } \mathrm{n} \text { e g y } \\
\text { C h a r t e r } \\
\text { Treaty }\end{array}$ & $\begin{array}{l}\text { It claims that } \\
\text { the Tri- } \\
\text { bunal's scru- } \\
\text { tiny should } \\
\text { not be ap- } \\
\text { plied to its } \\
\text { taxation } \\
\text { measures. } \\
\text { The } \\
\text { Claimant is } \\
\text { essentially a } \\
\text { criminal } \\
\text { enterprise }\end{array}$ & $\begin{array}{l}\text { Respondent } \\
\text { breached its } \\
\text { obligations } \\
\text { under Article } \\
\text { 13(1) of the } \\
\text { Energy } \\
\text { Charter } \\
\text { Treaty }\end{array}$ & $\begin{array}{l}\text { Claimant } \\
\text { won }\end{array}$ & $\begin{array}{l}\text { PART III } \\
\text { INVEST- } \\
\text { MENT } \\
\text { PROMO- } \\
\text { TION AND } \\
\text { PROTEC- } \\
\text { TION } \\
\text { and } \\
\text { ARTICLE } \\
13 \\
\text { EXPRO- } \\
\text { PRIATION }\end{array}$ \\
\hline
\end{tabular}




\begin{tabular}{|c|c|c|c|c|c|}
\hline 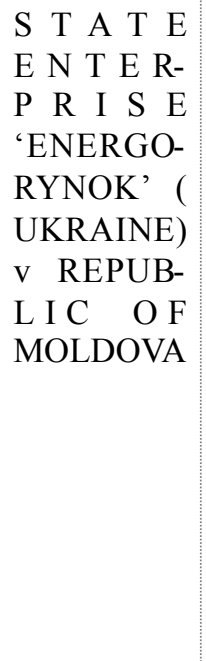 & $\begin{array}{l}\text { claims that } \\
\text { Moldova } \\
\text { violated its } \\
\text { obligations } \\
\text { under Article } \\
\text { 13(1), Arti- } \\
\text { cle } 10 \text { (1) }\end{array}$ & $\begin{array}{l}\text { The Tribunal } \\
\text { does not } \\
\text { have juris- } \\
\text { diction to } \\
\text { hear the } \\
\text { case. It also } \\
\text { rejects that it } \\
\text { had violated } \\
\text { any obliga- } \\
\text { tions under } \\
\text { Energy } \\
\text { Charter } \\
\text { Treaty. }\end{array}$ & $\begin{array}{l}\text { The Tribunal } \\
\text { found that it } \\
\text { lacked juris- } \\
\text { diction to } \\
\text { hear the } \\
\text { case. the } \\
\text { Claimants } \\
\text { were not the } \\
\text { investors } \\
\text { themselves. } \\
\text { The Arbitral } \\
\text { Tribunal } \\
\text { found these } \\
\text { submissions } \\
\text { to be incon- } \\
\text { sistent }\end{array}$ & $\begin{array}{l}\text { Claimant } \\
\text { lost }\end{array}$ & $\begin{array}{l}\text { PART III } \\
\text { INVEST- } \\
\text { MENT } \\
\text { PROMO- } \\
\text { TION AND } \\
\text { PROTEC- } \\
\text { TION } \\
\text { and } \\
\text { ARTICLE } \\
13 \\
\text { EXPRO- } \\
\text { PRIATION }\end{array}$ \\
\hline 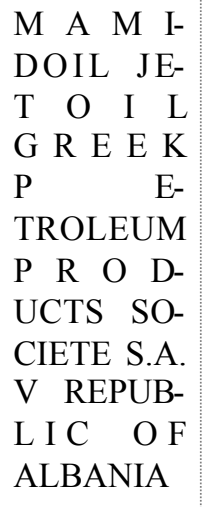 & $\begin{array}{l}\text { Breached } \\
\text { Article } \\
\text { 13(1), breach } \\
\text { of the fair } \\
\text { and equi- } \\
\text { table stan- } \\
\text { dard (FET) } \\
\text { under Article } \\
10(1) .\end{array}$ & $\begin{array}{l}\text { The Respon- } \\
\text { dent denies } \\
\text { all the claims } \\
\text { and disputes } \\
\text { the argu- } \\
\text { ments that it } \\
\text { had expro- } \\
\text { priated the } \\
\text { Claimant's } \\
\text { property }\end{array}$ & $\begin{array}{l}\text { It found that } \\
\text { the Respon- } \\
\text { dent did not } \\
\text { expropriate } \\
\text { the } \\
\text { Claimant's } \\
\text { investment }\end{array}$ & $\begin{array}{l}\text { Claimant } \\
\text { lost }\end{array}$ & $\begin{array}{l}\text { PART III } \\
\text { INVEST- } \\
\text { MENT } \\
\text { PROMO- } \\
\text { TION AND } \\
\text { PROTEC- } \\
\text { TION } \\
\text { and } \\
\text { ARTICLE } \\
13 \\
\text { EXPRO- } \\
\text { PRIATION }\end{array}$ \\
\hline $\begin{array}{c}\text { Electrabel v } \\
\text { Hungary }\end{array}$ & $\begin{array}{l}\text { Breached } \\
\text { Article } 10(1) \\
\text { and FET was } \\
\text { breached by } \\
\text { the termina- } \\
\text { tion of the } \\
\text { PPA agree- } \\
\text { ment }\end{array}$ & $\begin{array}{l}\text { he Respon- } \\
\text { dent rejected } \\
\text { all these } \\
\text { claims, } \\
\text { claiming it } \\
\text { did not } \\
\text { breach the } \\
\text { FET stan- } \\
\text { dard, that it } \\
\text { had rejected } \\
\text { the PPA due } \\
\text { to public } \\
\text { interests }\end{array}$ & $\begin{array}{l}\text { The Tribunal } \\
\text { rejected all } \\
\text { the claims of } \\
\text { the } \\
\text { Claimant. }\end{array}$ & $\begin{array}{l}\text { Claimant } \\
\text { lost }\end{array}$ & $\begin{array}{l}\text { PART III } \\
\text { INVEST- } \\
\text { MENT } \\
\text { PROMO- } \\
\text { TION AND } \\
\text { PROTEC- } \\
\text { TION }\end{array}$ \\
\hline
\end{tabular}




\begin{tabular}{|c|c|c|c|c|c|}
\hline \begin{tabular}{|c|} 
HRVATS- \\
KA v \\
SLOVENIA \\
(ICSID \\
Case No. \\
ARB $/ 05 / 24$ )
\end{tabular} & $\begin{array}{l}\text { violated Ar- } \\
\text { ticles } 10(1) \\
\text { and (13) }\end{array}$ & $\begin{array}{l}\text { The liability } \\
\text { had been } \\
\text { satisfied by } \\
\text { the offers.- } \\
\text { Claims of } \\
\text { the Energy } \\
\text { Charter } \\
\text { Treaty were } \\
\text { dropped vis- } \\
\text { à-vis the } \\
2001 \\
\text { Agreement }\end{array}$ & $\begin{array}{l}\text { Arbitral Tri- } \\
\text { bunal held } \\
\text { that the En- } \\
\text { ergy Charter } \\
\text { Treaty } \\
\text { claims made } \\
\text { against the } \\
\text { Respondent } \\
\text { were only } \\
\text { alternative } \\
\text { treaty bases } \\
\text { of claim }\end{array}$ & $\begin{array}{l}\text { Claimants } \\
\text { won }\end{array}$ & $\begin{array}{l}\text { PART III } \\
\text { INVEST- } \\
\text { MENT } \\
\text { PROMO- } \\
\text { TION AND } \\
\text { PROTEC- } \\
\text { TION } \\
\text { and } \\
\text { ARTICLE } \\
13 \\
\text { EXPRO- } \\
\text { PRIATION }\end{array}$ \\
\hline
\end{tabular}

